UNIVERSIDADE DE SÃO PAULO

INSTITUTO DE GEOCIENCIAS

\title{
CONTRIBUIÇÃO A GEOLOGIA E CONTROLE DAS MINERALIZAÇÕES AURÍFERAS DA REGIÃO DE PEIXOTO DE AZEVEDO - MT
}

Antonio João Paes de Barros

Orientador: Prof. Dr. Evaristo Ribeiro Filho

DISSERTAÇÃO DE MESTRADO

COMISSÃO JULGADORA

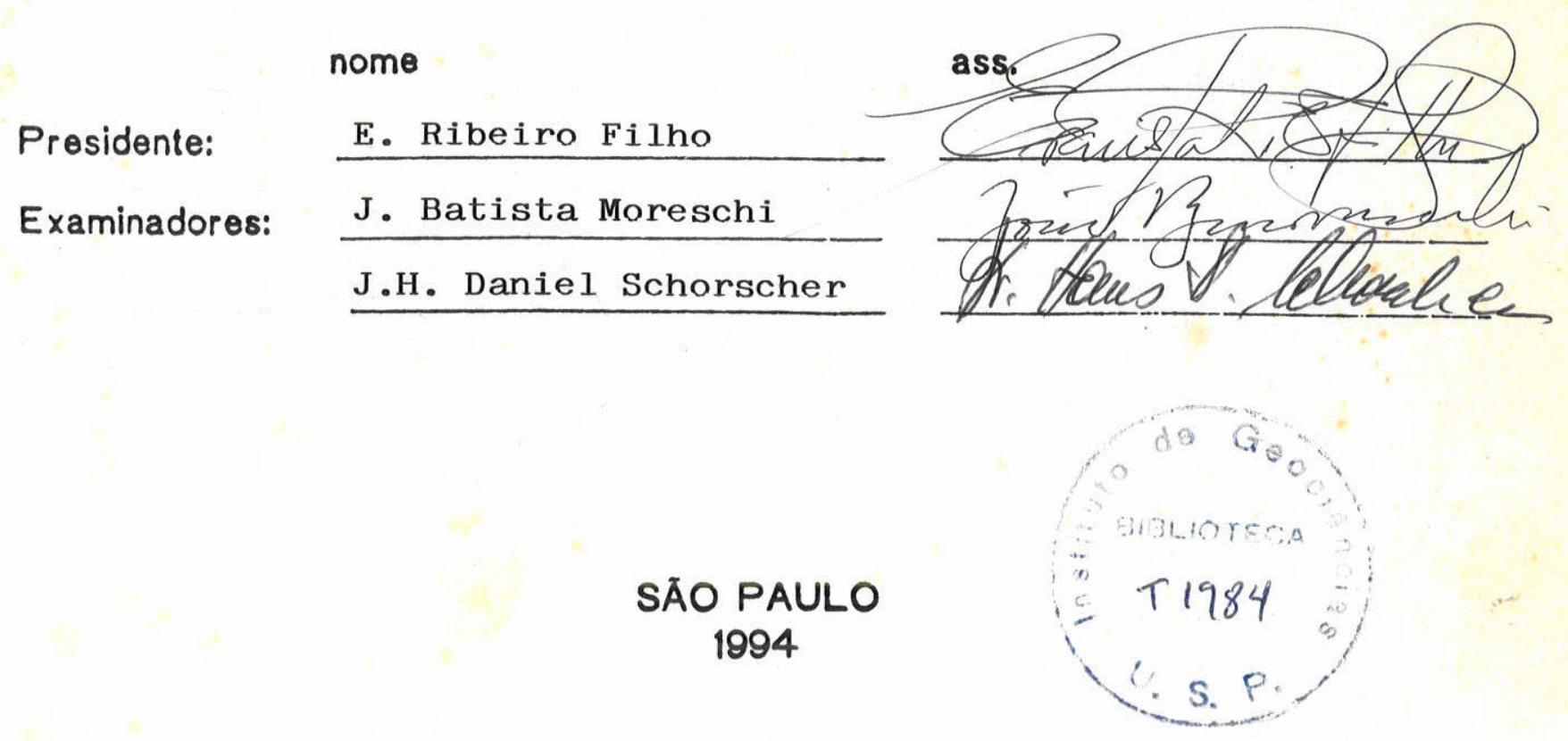




\section{UNIVERSIDADE DE SÃO PAULO INSTITUTO DE GEOCIÊNCIAS}

\section{CONTRIBUIÇÃO A GEOLOGIA E CONTROLE DAS MINERALIZAÇÕES AURÍFERAS DA REGIÃO DE PEIXOTO DE AZEVEDO - MT}

Antonio João Paes de Barros

Orientador: Prof. Dr. Evaristo Ribeiro Filho

DISSERTAÇÃO DE MESTRADO

Programa de Pós-Graduação em Geologia Econômica
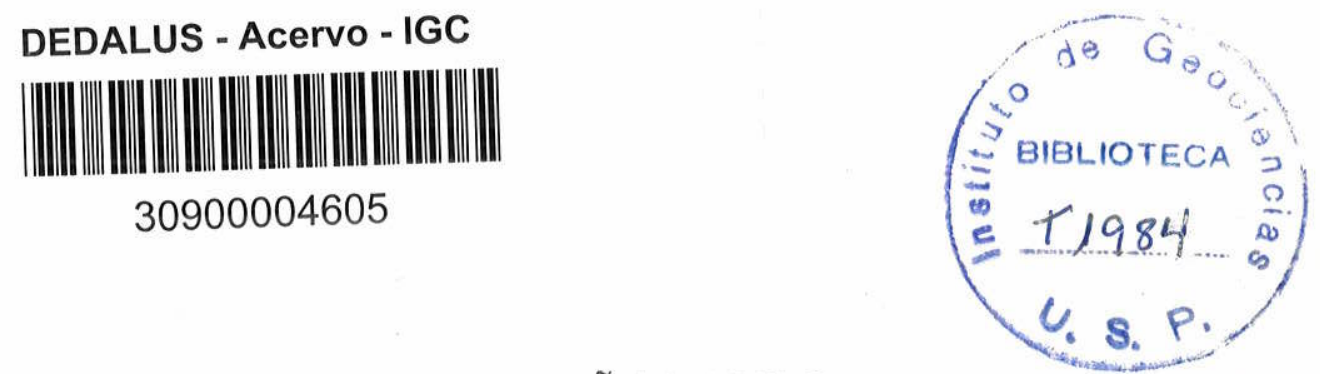

SÃO PAULO 1994 
In memoriam a

Zuleide Figueiredo Paes

de Barros. 


\section{AGRADECIMENTOS}

Meus sinceros agradecimentos:

- a esposa Leticia T. Lobo Paes de Barros, companheira em todos os momentos. caminhada.

- aos colegas de profissão com os quais convivi e aprendi durante está

Meus agradecimentos especiais aos senhores:

- Professor Dr. Evaristo Ribeiro Filho, pela tolerância e dedicação para a conclusão desta dissertação.

- aos Geológos João Batista Matos, Francisco João de Souza (in memoriam), Nelson Marinho de Oliveira e Amarildo Salinas Ruiz pela convivência e apoio recíprocos.

- aos Geológos Waldemar Abreu Filho (CPRM) e Olavo Caramori (UNIGEO) pelo apoio laboratorial recebido das respectivas instituições.

- ao Professor Dr. Jorge Silva Bettencourt pela revisão do texto

- aos Geológos Salatiel Alves de Araujo, Gercino D. da Silva, Izaias M. de Souza, Wanderley M. de Resende, Marcos V. Paes de Barros Josué Antonio da Silva, Alvaro P. Quadros e Elvio Scheele, pela companhia, apoio e sugestões durante os trabalhos.

- ao Químico Lázaro José Oliveira da METAMAT, pela realização de algumas análises químicas.

- aos Desenhistas Joaquim Pedro Ribeiro e Ademildo de Figueiredo pelos trabalhos de desenho.

- aos Técnicos da METAMAT José Roque Soares e Antonio da Silva Lisboa pelo apoio durante as etapas de campo.

- ao Estudante de Geologia Franco Weber pela digitação do texto.

- a Sra. Sâmia Nery e ao Sr. Benedito Jesus de Almeida pela ajuda na montagem do relatório final, e

- a Companhia Matogrossense de Mineração (METAMAT), na pessoa dos Diretores Edísio R. Rocha e Wilson Menezes Coutinho, pelo apoio efetivo para a conclusão deste trabalho. 


\section{APRESENTAÇÃO}

Os resultados das pesquisas e informações reunidas nesta Dissertação de Mestrado tiveram o objetivo de implementar a pesquisa geológica e propiciar o entendimento dos principais controles das mineralizaçð̃es primárias de ouro da região de Peixoto de Azevedo - MT.

A sub-província aurífera de Peixoto de Azevedo constitui parte da importante Província Aurífera do Tapajós. Está sub-província se estende ao longo da direção W-NW, margeando a borda sul do Graben do Cachimbo, e é responsável por significativa parcela da produção aurífera oriunda dos garimpos da Amazônia Matogrossense.

A decisão de desenvolver estudos para elaboração de uma Dissertação de Mestrado nessa região, deve-se ao desconhecimento geológico e a importância metalogenética dessa sub-província, de forma a prestar uma contribuição significativa a Geologia do Brasil. 


\section{SUMÁRIO}

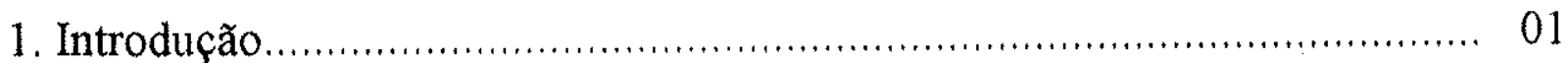

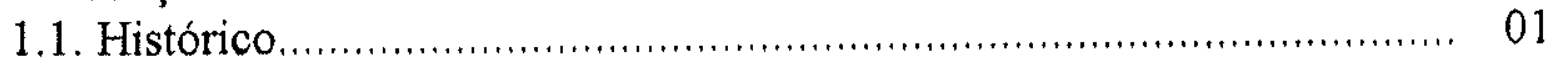

1.2. Localização e Vias de Acesso ...................................................... 02

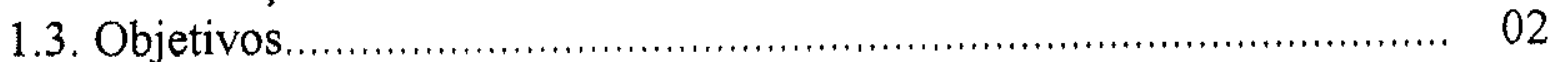

1.4. Materiais e Métodos.......................................................... 02

2. Aspectos Fisiográficos e Geomorfológicos...................................... 07

2.1. Hidrografia ..................................................................... 07

2.2. Clima

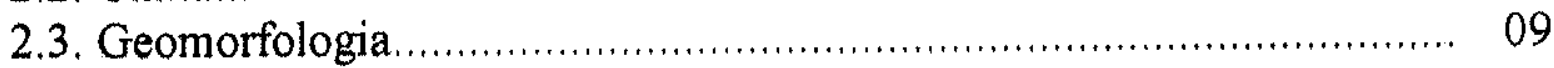

3. Geologia Regional ............................................................. 11

3.1. Evolução Geotectônica ..................................................... 11

3.2. Regionalização Lito-Estratigráfica .......................................... 13

3.2.1. Granitóides Arqueanos................................................... 15

3.2.2. Granitóides Transamazônicos............................................. 16

3.2.3. Granitóides do Proterozóico Médio..................................... 18

3.2.4. Vulcano-Plutonismo Uatumã .............................................. 20

3.2.5. Grupo Beneficente.......................................................... 23

3.2.6. Magmatismo Básico .......................................................... 24

3.2.7. Coberturas Fanerozóicas.................................................... 24

3.2.8. Coberturas Cenozóicas.................................................. 25

4. Aspectos Gerais Sobre Mineralizações Auriferas em Contexto de Zonas de Cisalhamento Dúcteis...................................... 26

4.1. Mecanismo de Deformação......................................................... 26

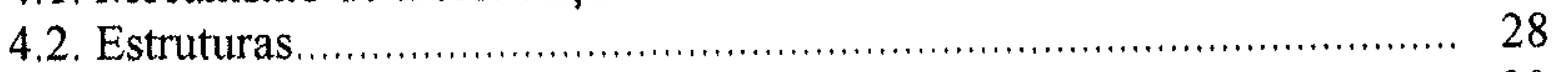

4.3. Produtos Deformacionais............................................................ 30

4.4. Mecanismos de Movimentação de Fluídos e Formação

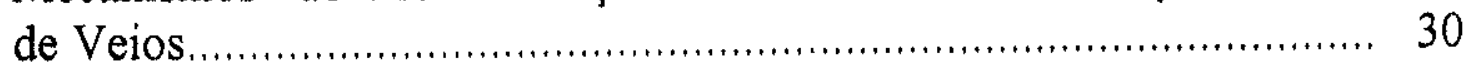

4.5. Controles Regionais......................................................... 32

4.6. Tipologia dos Depósitos.......................................................... 35

5. Geologia Local .......................................................................... 37

5.1. Generalidades.................................................................... 37

5.2. Complexo Xingu .............................................................. 37

5.3. Granitóides Arqueanos....................................................... 48

5.4. Zonas de Cisalhamentos Dúcteis............................................... 58

5.5. Granitos Pré-Uatumã ............................................................... 63

5.5.1. Granito Juruena .................................................... 63 
5.5.2. Granito Matupá ............................................................... 69

5.5.3. Granitos Indivisos ........................................................ 79

5.6. Grupo Uatumã ................................................................. 81

5.7. Stocks, Diques, Apófises e Sills ............................................. 82

5.8. Unidade Sedimentar ................................................................ 84

5.9. Aluviões Recentes................................................................ 84

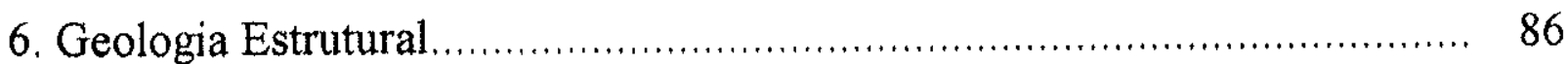

6.1. Domínio Xingu ............................................................... 87

6.2. Domínio Iriri .............................................................. 88

7. Descrição dos Depósitos.................................................................... 94

7.1. Depósitos do Tipo I ................................................................. 94

7.1.1. Sistema Paraíba............................................................. 94

7.1.1.1. Filão do Paraíba....................................................... 96

7.1.2. Sistema Mineiro .......................................................... 104

7.1.2,1. Filão do Mineiro .................................................. 104

7.1.2.2. Filão do Domingos/Sebastião................................. 104

7.1.3. Sistema Serrinha ........................................................... 107

7.1.3.1. Filão da Serrinha ................................................ 107

7.1.3.2. Filão do Melado .................................................... 111

7.1.3.3. Filão do Roberto Gaúcho ...................................... 114

7.1.4. Sistema Flor da Serra ...................................................... 114

7.1.4.1. Filão do Olerindo ................................................. 117

7.1.4.2. Filão do Geraldo .................................................... 117

7.1.4.3. Filão do Naiuram ................................................ 117

7.1.5. Sistemas Indiferenciados.............................................. 121

7.2. Depósitos Tipo II ................................................................ 126

7.3. Depósitos Tipo III ............................................................ 129

8. Conclusões e Recomendaçס̃es.......................................................... 133

Referências Bibliograficas........................................................... 137

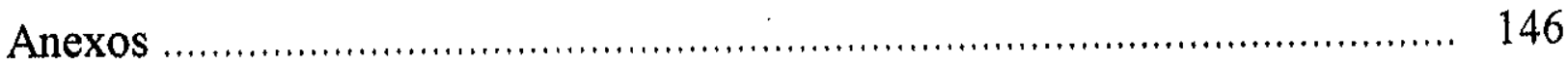

Anexo 01 - Mapa Geológico

Anexo 02 - Mapa de Afloramentos e Áreas Garimpadas 


\section{SUMÁRIO DAS FIGURAS}

Figura 01. Mapa de Localização e Vias de Acesso............................. 3

Figura 02. Esboço Geológico da Reserva Garimpeira de Peixoto de Azevedo - MT

Figura 03. Compartimentação Geomorfológica do Estado de Mato Grosso.

Figura 04. Esboço Geotectônico das Províncias Estruturais e Geocronológicas do Craton Amazônico. Teixeira et al (1989)

Figura 05. Esquema da Evolução Geotectônica da Província Rio Negro - Juruena, Baseado na Tectônica de Placas.Tassinari (1981)

Figura 06. Diagrama QAP-Dall'Agnol et. al. (1987)

Figura 07. Modelo Esquemático para uma Zona de Cisalhamento. Sibson (1977)....

Figura 08. Sistemas de Fraturas Previstas em um Binário de Cisalhamento.

Figura 09. Classificação de Rochas Cataclásticas. Sibson 1977

Figura 10. Diagrama AFM - Complexo Xingu, Irvine e Baragar (1971)

Figura 11. Diagrama QAP - Composição Modal Granitóides Arqueanos, Streickeisen (1976)

Figura 12. Diagrama QAP - Composição Modal Granitóides Arqueanos, Le Maitre (1989).

Figura 13. Índice de Aluminosidade, Granitóides Arqueanos, Maniar \& Piccoli (1989).

Figura 14. Diagrama $\mathrm{Feo} / \mathrm{MgO} / \mathrm{Na}_{2} \mathrm{O}+\mathrm{K}_{2} \mathrm{O}$ - Granitóides Arqueanos, Segundo Irvine e Baragar (1971). 
Figura 15. Diagrama $\mathrm{SiO}_{2}$ - $\mathrm{FeO} / \mathrm{MgO}$ - Granitóides Arqueanos, Miyashiro (1974)

Figura 16. Diagrama QAP - Composição Modal dos Granito Juruena, Streickeisen (1976).

Figura 17. Diagrama QAP - Composição Modal dos Granito Juruena, Le Maitre (1989)

Figura 18. Diagrama $\mathrm{FeO} / \mathrm{MgO} / \mathrm{Na}_{2} \mathrm{O}+\mathrm{K}_{2} \mathrm{O}$ - Granito Juruena Segundo Irvine e Baragar (1971) ....................................... 70

Figura 19. Índice de Aluminosidade - Granito Juruena, Segundo Maniar e Picoli, 1989.

Figura 20. Diagrama $\mathrm{SiO}_{2}+\mathrm{TiO}_{2}$ - Granito Juruena, Segundo Maniar \& Piccoli, (1989).

Figura 21. Planta (a) e Secção Esquemática (b) do Garimpo de Serrinha - Matupá.

Figura 21c Representação Esquemática - Garimpo da Serrinha - Frente Trevisan.

Figura 22. Diagrama QAP - Granitos Matupá. Streckeisen (1976)....... 75

Figura 23. Disposição Relativa dos Elementos Estruturais no Sistema Paraíba e Filão do mineiro

Figura 24. Planta Esquemática do Filão do Paraíba

Figura 25. Seção Geológica Esquemática do Filão do Paraíba. 98

Figura 26. Detalhe do Veio do Filão do Paraíba. 99

Figura 27. Planta Esquemática - Filão do Domingos/Sebastião. 106

Figura 28. Disposição Relativa dos Elementos Estruturais no Sistema Serrinha 
Figura 29. Projeção Estereográfica das Principais Estruturas Associadas ao Sistema Serrinha......................................... 109

Figura 30. Planta Esquemática - Filão da Serrinha............................ 110

Figura 31. Planta Esquemática - Filão do Melado............................... 112

Figura 32. Planta Esquemática - Filão do Roberto Gaúcho (PA-

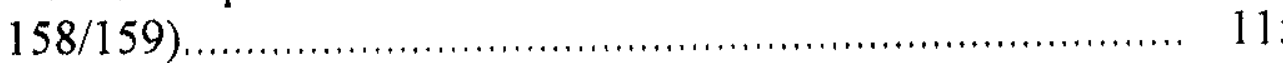

Figura 33. Disposição Relativa dos Elementos Estruturais no Sistema Flor da Serra ...................................................... 118

Figura 34. Planta Esquemática - Filão do Olerindo (GR-14),............. 119

Figura 35. Planta Esquemática - Filão do Nairuam (GR-05) .............. 122

Figura 36. Planta Esquemática - Filão da Sede .............................. 124

Figura 37. Representação Esquemática Filão do Cubu (GR-31/32) ...... 125

Figura 38. Planta Esquemática - Filão do Herédio.......................... 126

Figura 39. Planta Esquemática - Filão do Zé Deco........................... 127 


\section{SUMÁRIO DAS TABELAS}

Tabela 01. Dados Geocronológicos Sobre os Granitóides Arqueanos.... 21

Tabela 02. Dados Geocronológicos Sobre os Granitóides Transamazônicos

Tabela 03. Idade de Granitos e Vulcânicas do Proterozóico Médio da Região do Trabalho

Tabela 04. Análises Químicas, Norma (CIPW) e Moda para os Tipos Petrográficos do Complexo Xingu.

Tabela 05. Análises Químicas, Norma (CIPW) e Moda dos Granitóides Arqueanos.

Tabela 06. Análises Químicas e Moda para Rochas Miloníticas.

Tabela 07. Análises Químicas, Norma (CIPW) e Moda dos Granitos Juruena.

Tabela 08. Análises Químicas, Norma (CIPW) e Moda para os Granitos Matupá. 76

Tabela 09. Análise Químicas para Granitos Indivisos

Tabela 10. Análises Químicas para Gabros, Diabásios, Basaltos e Andesitos.

Tabela 11. Filões Mapeados na Região de Guarantã do Norte. 89

Tabela 12. Filões Mapeados na Região de Peixoto de Azevedo....... 90

Tabela 13. Filões Mapeados na Região de Matupá. 92

Tabela 14. Disposição Geométrica das Principais Estruturas Observadas no Sistema Paraíba.

Tabela 15. Disposição Geométrica das Principais Estruturas Observadas no Sistema Serrinha. 
Tabela 16. Disposição Geométrica das Principais Estruturas Observadas no Sistema Flor da Serra ................................ 116 


\section{RELAÇÃO DE MICROFOTOS}

Microfoto 01. Talco-Clorita Xisto Milonítico ...................................... 43

Microfoto 02. Talco - Clorita Xisto ............................................... 45

Microfoto 03. Clinopiroxenito .................................................... 47

Microfoto 04. Biotita Tonalito Protomilonítico.................................. 55

Microfoto 05. Quartzo Milonito ...................................................... 62

Microfoto 06. Granito Milonitizado .............................................. 62

Microfoto 07. Biotita Granodiorito ................................................ 67

Microfoto 08. Biotita Granodiorito ................................................ 74

Microfoto 09. Granito Hidrotermalizado......................................... 80 


\section{RELAÇÃO DE FOTOS}

Foto 01. Gnaísses Tonalíticos .............................................. 42

Foto $02 . \quad$ Talco-Clorita Xisto .................................................... 44

Foto 03. Metapiroxenito ..................................................... 47

Foto 04. Granodiorito Gnaíssico ........................................... 56



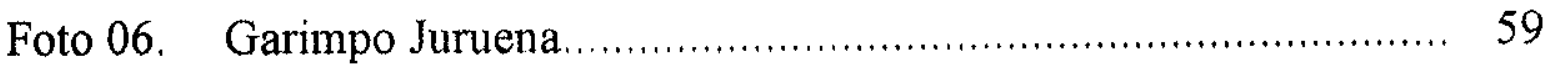

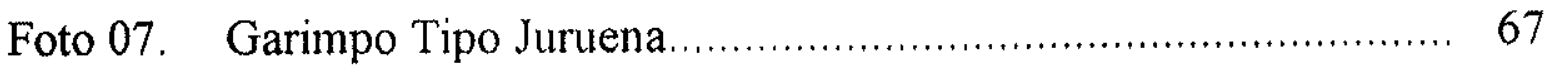

Foto 08. Granito Matupá ............................................................ 74

Foto 09. Granito Hidrotermalizado ............................................ 77

Foto 10. Garimpo da Serrinha ............................................. 80

Foto 11. Gnaísses Tonalíticos ............................................... 82

Foto 12. Filão do Paraíba ............................................................ 100

Foto 13. Halo/Filão do Paraíba .................................................. 102

Foto 14. Detalhes do Veio do Filão do Paraíba .................................. 102

Foto 15. Filão do Mineiro ......................................................... 105

Foto 16. Filão da Serrinha ..................................................... 111

Foto 17. Filão do Melado ...................................................... 113

Foto 18. Filão do Olerindo .................................................... 120

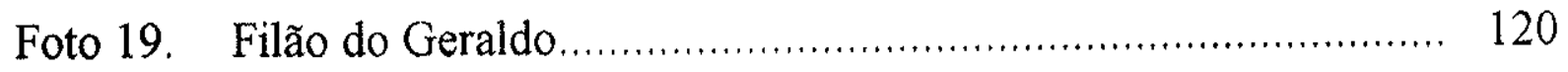

Foto 20. Contato Granito Hidrotermalizado/Pegmatitos...................... 130 
Foto 21. Granito Hidrotermalizado.

Foto 22. Niveis Pegmatiticos Piritosos. 


\section{RESUMO}

A Sub-província de Peixoto de Azevedo está localizada na região centro norte do Estado de Mato Grosso (Brasil), sendo parte da Província aurífera do Tapajós.

Os trabalhos de mapeamento geológico permitiram a individualização dentro do Complexo Xingu de duas unidades Lito-estruturais típicas de terrenos arqueanos, caso dos Granitóides Arqueanos e das Zonas de Cisalhamentos Dúcteis. Os Granitóides Arquenos contituem uma assembléia com tonalitos, granodioritos e quartzo dioritos, gnaissificados, com características similares aos terrenos tipo TTG.

As Zonas de Cisalhamentos Dúcteis de direção geral N-NW, foram posicionadas e interpretadas dentro do contexto evolutivo dos terrenos arqueanos, sendo consideradas como estruturas subordinadas e vinculadas a binários de deformação regionais de direção W-NW. Tais estruturas constituem zonas preferenciais de deformação, limitando a Província Amazonia Central e condicionando a instalação de bacias tipo Graben durante o Proterozóico Médio.

O granito tipo Juruena, posicionado no Proterozoico Inferior está representado principalmente por biotita monzo granitos e biotita granodioritos, per aluminosos a meta-aluminosos, de natureza cálcio-alcalina, com enclaves de composição diorítica e anfibolítica.

O Granito Matupá aflora em área restrita. Os corpos são de composição granodiorítica a monzogranítica e apresentam-se localmente alterados, com a paragênese transformada por fluidos hidrotermais de notável afinidade aurífera.

Dois dominios estruturais foram caracterizados, o Xingu e Iriri. No Domínio Xingu estão impressos os padrões estruturais típicos dos terrenos arqueanos, com zonas de cisalhamentos e lineamentos estruturais orientados preferencialmente segundo a direção NW. O Domínio Iriri tem distribuição mais restrita e ocorre em uma região onde predominam litotipos gerados no contexto do magmatismo Uatumã, com marcante sistema de lineamentos e falhas de direção geral NE.

Com relação as mineralizações auriferas foram caracterizados três tipos de depósitos. Os depósitos tipo I contituem corpos filoneanos alojados em fraturas geradas a partir da evolução da deformação progressiva nos vários sistemas de cisalhamentos dúcteis, que afetam principalmente os Granitóides Arqueanos e o Complexo Xingu. Os depósitos tipo II constituem principalmente filões de pequeno porte gerados nas regiões de ocorrência dos Granitos tipo Juruena e Matupá. Os depósitos tipo III contituem mineralizações do tipo disseminado ou stockworks, alojadas em determinadas porções dos granitos tipo Matupá, constituindo massas hidrotermalizadas. 


\section{ABSTRACT}

The Sub-province of Peixoto de Azevedo is located in the north center region of the state of Mato Grosso (Brasil), being part of the gold Province of Tapajós.

The geological maping works allowed the individualization in the complex Xingu of two litho-structures units that are typical from archeans terrains case of Archeans Granitoids, and of the Shear Zones Ductiles.

The Archeans Granitoids are an assembly with tonalites, granodiorites and quartz-diorites, gnaissic, whose features are similar to the terrains TTG type.

The Shear Zones Ductiles, of general trend N-NW, were placed and interpreted in the evolutive context of archeans terrains being considered as subordinate structures and associated to binaries of regional deformations of trend W-NW. These structures are prefered zones of deformation boundering the Central Amazonian Province and conditioning the installation of basins Graben type during the middle proterozoic.

The Juruena Granite type placed in the Proterozóico Inferior is represented mainly by biotite monzogranites and biotite granodiorites, of calcalkaline nature, with enclaves of dioritic and anfibolitic composition.

The Matupá Granite occur in a restrict. The bodies are of granodioritic to monzogranitic composition and show themselves changed, with the paragenesis converted by hidrothermal fluids with notable golden afinity.

Two structural dominions were characterizated, the Xingu and Iriri. In the Xingu Dominion the structural patterns of archeans terrains are printed with shear zones and lineations structures guided mainly according to NW trend. The Iriri Domínion has a more restrict distribution and occur in a region where lithotypes predominate in the context of magmatits Uatumã, striking with intense system of lineations and falts of NE general trend.

Concerning to the golden mineralizations, three kinds of deposits were characterizated. The deposits type I constitute lode corps placed in fractures originated from the evolution of progressive deformation in the several systems of shear ductiles which affect mainly the Archeans Granitoids and the Complex Xingu. The deposits type II are mainly lodes of small size produced in the regions of granites type Juruena and Matupá occurences. The deposits type III are mineralizations kinds of disseminate or stockworks, placed in certain parts of Matupá Granites type, constituing hidrothermal masses. 


\section{1 - INTRODUÇÃO}

\section{1 - Histórico}

A descoberta das primeiras ocorrências de ouro na região de Peixoto de Azevedo se deu durante o ano de 1978, quando os trabalhos de abertura da rodovia Cuiabá-Santarém (BR-163) atingiram o local onde atualmente está implantada a cidade de Peixoto de Azevedo, na altura do quilômetro 700 dessa rodovia.

A divulgação da descoberta fez afluir para a região milhares de garimpeiros, resultando na descoberta de dezenas de depósitos secundários, nas planices aluvionares, desenvolvidas principalmente ao longo das drenagens de segunda e terceira ordens, caso dos córregos: Baixão Novo, Baixão Velho, Grota Rica, Jaó, Simão, Peixotinho, Najá, Micharia, Grota Funda e muitos outros.

A garimpagem, inicialmente manual, evoluiu para a lavra com utilização de dragas, e bombas para suç̧ão de cascalho de 3" a 5". Finalmente em 1981, começaram a ser utilizadas as balsas e dragas escariantes para a exploração dos aluviões existentes nas calhas dos rios Peixoto de Azevedo, Braço Norte e Peixotinho.

Em 1983 a descoberta e exploração do primeiro depósito primário da região, no caso o garimpo da Serrinha, na localidade de Santo Antônio, atualmente município de Guarantã do Norte, desencadeou a exploração em mais de uma centena de veios.

Devido aos inevitáveis conflitos entre garimpeiros e empresas de mineração, foi criada através da Portaria Ministerial número 551, publicada no Diário Oficial da União do dia 09 de maio de 1983, a reserva garimpeira de Peixoto de Azevedo, com uma área de 657.500 ha.

Dos órgãos e instituições vinculadas ao setor mineral estão presentes na região, o Sindicato dos Garimpeiros do Estado de Mato Grosso, fundado em fevereiro de 1983, a Caixa Econômica Federal, a METAMAT e o DNPM. O DNPM, através do convênio CPRM/DNPM, implantou em 1980 escritório na cidade de Peixoto de Azevedo, para dar sustentação às atividades do então Projeto "Estudos dos Garimpos Brasileiros".

A edição da legislação que disciplinou o regime de lavra garimpeira, inclusive no interior de reservas garimpeiras, veio incrementar a entrada de empresas de mineração na região, através de associações com proprietários de garimpos, principalmente nos prospectos primários de maior potencial, onde a atividade garimpeira tomou-se inviável, em função da utilização de técnicas exploratórias inapropriadas. 


\section{2 - Localização e Vias de Acesso}

As pesquisas desenvolvidas nesta dissertação de mestrado foram efetuadas em uma área que se situa na região norte do Estado de Mato Grosso, abrangendo parte dos municípios de Peixoto de Azevedo, Guarantã do Norte e Matupá, (Figura 01). Quanto a situação cartográfica, a área abrange parte das folhas SC.21-Z-B-I (Vila Guarita) e SC.21-Z-B-II (Agropecuária Cachimbo), na escala 1:100.000, editadas pelo DSG.

As cidades de Peixoto de Azevedo e Matupá situam-se dentro da área da pesquisa, (Figura 01), e constituem polos de desenvolvimento regional.

$\mathrm{O}$ acesso à região pode ser feito pela BR-163 (Cuiabá-Santarém), até a cidade de Peixoto de Azevedo, a cerca de $700 \mathrm{Km}$ de Cuiabá, sendo $620 \mathrm{Km}$ com pavimentação asfáltica. $O$ acesso é feito também através de vôos regulares mantidos pela TABA, Transportes Áereos da Bacia Amazônica, de Cuiabá até a cidade de Matupá.

\section{3 - Objetivos}

O principal objetivo deste trabalho é contribuir para o conhecimento geológico da mais produtiva provincia aurifera do Estado de Mato Grosso, através do mapeamento e caracterização das litologias, das estruturas, da tipificação dos depósitos auríferos e da identificação dos controles metalogenéticos, visando sobretudo estabelecer parâmetros orientativos aos futuros trabalhos de prospecção e exploração mineral na região.

\section{4 - Materiais e Métodos}

Dentro do objetivo maior de caracterizar os controles das mineralizações auríferas da região de Peixoto de Azevedo, foi necessário estabelecer uma linha métodológica que melhor se ajustasse às dificuldades operacionais e materiais existentes.

Dentre algumas dificuldades de ordem prática, podemos citar:

- As bases cartográficas disponiveis, no caso, as fotografias aéreas da USAF (1966), as folhas planialtimétricas SC.21-Z-B-I / SC.21-Z-B-II, impressas pelo DSG, em 1982 e as imagens de radar (1975/76), não retratam a infraestrutura atual, uma vez que a ocupação efetiva da região se deu após 1978;

- As fotografias aéreas e imagens de radar mostraram-se inadequadas para a interpretação fotogeológica, face ao relevo arrasado e a densa cobertura vegetal;

- Para apoio aos trabalhos de campo elaborou-se uma base cartográfica atualizada, imprescindivel para o acompanhamento permanente das frentes de garimpo (cavas, poços, catas), uma vez que tais locais constituem as melhores exposições para obtenção de dados lito-estruturais e metalogenéticos; 


\section{MAPA DE LOCALIZAGÃO \\ VIA DE ACESSO}

ESCALA APROXIMADA $1: 7.500000$

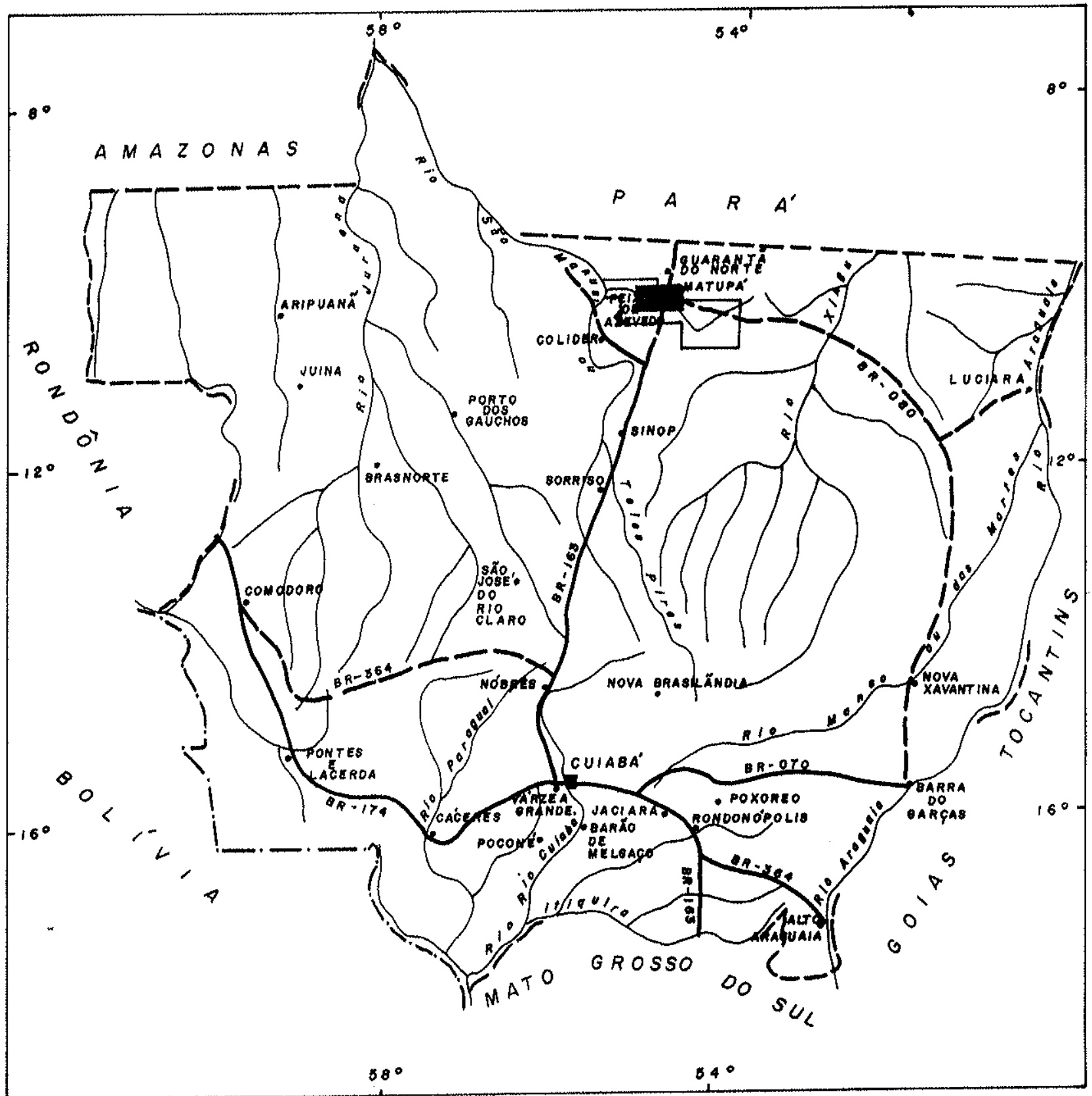

$L \quad E \quad O \quad E N D A$

- Capitol do Estodo

- Sedo do Munioíplo

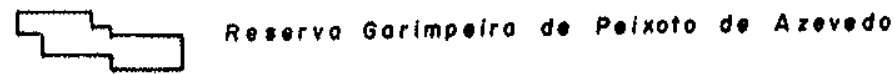

- Rodovio com ostalto

Rodovia sem astalto

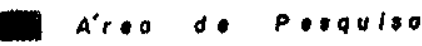

OR Federal

MT EITOdual

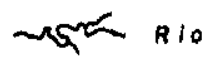

-.- Diviog Internocionol

- Diviso interestadual 
- Como uma das características intrínsecas à atividade garimpeira é a desorganização e o nomadismo, muitas informações do substrato geológico ficam perdidas quando as frentes são abandonadas.

Nestas condições, buscamos a princípio obter informações cartográficas e fotogeológicas em imagens de satélite Spot, bandas 123, na escala 1:50.000 (cena de junho 1989) ; Landsat TM5, bandas 234 e 134 , na escala 1:50.000 (cenas de julho 1991 e agosto de 1990/92) e Landsat TM5 banda 4, na escala 1:100.000 (cena de junho 1991). A partir das mesmas, com as informações obtidas em reconhecimentos anteriores e da literatura regional, efetuamos um mapeamento sistemático, direcionado para apresentação de um mapa na escala 1:100,000. Entretanto, a escassez de afloramentos naturais induziu ao mapeamento das regiões com maior concentração de atividade extrativa e onde as exposições das mineralizações primárias eram mais significativas.

Durante os trabalhos de campo dois tipos de materiais foram objeto de amostragem sistemática: amostras de rochas, dos tipos litológicos mais expressivos para confecção de lâminas petrográficas, e amostras de minério aurifero, principalmente do tipo veio de quartzo, para estudos mineralógicos e texturais através de seções polidas.

\section{Amostras de Rochas}

Foram descritas cerca de 60 lâminas petrográficas, das diversas unidades mapeadas na região. Nas rochas graníticas menos deformadas e alteradas, procedeu-se a análise modal para a classificação mineralógica dos granitóides através do diagrama QAP (Streickeisen 1976).

As lâminas selecionadas para contagem de pontos visando a determinação de moda apresentavam granulação fina a média, sendo contados em média entre 450 a 600 pontos por amostra.

Utilizou-se também para avaliação da moda, em cerca de 15 amostras, a técnica para colorir feldspato potássico em lâmina, que permite estimar o percentual de feldspatos na rocha, através do ataque com ácido fluorídrico e posterior imersão em cobaltinitrito de sódio conforme Deer, Howie e Zussman (1981).

Foram encaminhadas para análise química cerca de 20 amostras de rochas para dosagem dos elementos maiores e dos seguintes elementos traços: $\mathrm{Ba}$, $\mathrm{Rb}, \mathrm{Sn}, \mathrm{Y}, \mathrm{Zn}, \mathrm{Nb}, \mathrm{Pb}, \mathrm{Cu}, \mathrm{Mo}, \mathrm{W}, \mathrm{Ba}, \mathrm{Sr}, \mathrm{Ag}, \mathrm{Ni}, \mathrm{S}, \mathrm{Co}, \mathrm{V}, \mathrm{As}, \mathrm{Zr}$, Th e Au.

Nas amostras de rochas analisadas no laboratório da GEOSOL, utilizou-se os seguintes métodos analíticos:

$\mathrm{SiO}_{2}, \mathrm{Al}_{2} \mathrm{O}_{3}, \mathrm{Fe}_{2} \mathrm{O}_{3}, \mathrm{CaO}, \mathrm{MgO}, \mathrm{TiO}_{2}, \mathrm{P}_{2} \mathrm{O}_{5}, \mathrm{Cr}_{2} \mathrm{O}_{3}$ e $\mathrm{NiO}$ fluorescência de Raios-X - amostras fundidas com tetraborato de lítio. 
$\mathrm{FeO}$ - volumetria - titulação do $\mathrm{Fe}++$ por solução padrão de $\mathrm{K}_{2} \mathrm{Cr}_{2} \mathrm{O}_{7}$ em presença de difenilsulfonato de sódio como indicador.

$\mathrm{Na}_{2} \mathrm{O}, \mathrm{K}_{2} \mathrm{O}, \mathrm{MnO}$ - Espectrometria de Absorção Atômica após abertura total da amostra com $\mathrm{HF}-\mathrm{HNO}_{3}$.

F - Eletrodo de Íon Específico.

P.F - Calcinação à $1000^{\circ} \mathrm{C}$, até peso constante.

$\mathrm{S}, \mathrm{Cl}$ - Fluorescência de Raios - X, usando técnica de pó prensado.

Para os elementos traços analizados no laboratório LAMIN/CPRM, se utilizou os seguintes métodos analíticos: Mo, V, Au.

Espectrometria de Absorção Atômica - $\mathrm{Cu}, \mathrm{Pb}, \mathrm{Zn}, \mathrm{Co}, \mathrm{Ni}, \mathrm{Cr}, \mathrm{Ba}, \mathrm{Bi}$,

Fluorescência de Raios X - Nb, Zr, Y, Sr, Rb.

$O$ interesse nesses dados químicos deve-se principalmente a grande diversidade de rochas graniticas aflorantes na região, onde há inexistência de boas exposições e relações de contato, tornando necessário a utilização de parâmetros químicos, que auxiliem a identificação das diferentes tendências, das principais séries graníticas e possíveis filiações metalogenéticas.

Outro aspecto que foi considerado refere-se às alterações químicas em expressivas massas rochosas afetadas pelo desenvolvimento de mega zonas de cisalhamento dúcteis, onde os fluídos têm ação significativa nas transformações minerais, liberando grandes quantidades de ouro e/ou sílica para os locais de deposição, com geração de auréolas geoquímicas, muitas vezes caracterizadas pela presença de determinados elementos indicadores.

Os dados químicos de rochas foram tratados através do programa NEWPET (cf. Clarke, 1990 e 1992).

\section{Amostras de Minérios}

Com relação a amostragem dos veios e outros eventuais minérios, apesar de serem reconhecidos pelo menos uma centena de depósitos primários, raras vezes foi possivel realizar coletas criteriosas do minério, halos de alteração e encaixantes, face a própria dinâmica do garimpo.

As análises químicas foram realizadas em diversos laboratórios (LBPM/NOMOS, MORRO VELHO, METAGO, CPRM/LAMIN, METAMAT e GEOSOL), por falta de um apoio logístico institucional específico.

Nas amostras de minério, preferencialmente do tipo veio de quartzo,com peso em torno de $1 \mathrm{Kg}$, efetuou-se análise para ouro e metais associados ( $\mathrm{Cu}, \mathrm{Pb}, \mathrm{Zn}, \mathrm{Ag}, \mathrm{As}, \mathrm{B}, \mathrm{Bi}, \mathrm{Ba}, \mathrm{Fe}, \mathrm{Ni}, \mathrm{W}, \mathrm{Sb}, \mathrm{Mn}, \mathrm{Co}$ e V), as 
amostras de veio foram coletadas preferencialmente através da abertura de canaletas nos corpos de minério ou em pilhas de minério, de forma a se obter amostras representativas dos diversos tipos de minério. Convém realçar que, no caso, as amostras foram encaminhadas para diversos laboratórios, com várias amostras sendo dosadas apenas para ouro.

Os métodos analíticos utilizados foram os seguintes:

- Laboratório da METAGO (lote na 5929/88)

Absorção Atômica/ácido forte-Au, $\mathrm{Ag}, \mathrm{B}, \mathrm{Ba}, \mathrm{Cu}, \mathrm{Fe}, \mathrm{Zn}, \mathrm{Pb}$

Expectrometria Óptica de Emissão - Sb, $\mathrm{WO}_{3}$

Fluorescência de Raios X - As

- Laboratório NOMOS (lote 1/ES 0290.90)

Fusão/Copelação/Absorção Atômica - $\mathrm{Au}$ e Pt

Fusão/Colorimetria - As e W

Ácido Forte/Absorção Atômica - As, S, Bi, Co, Ni e Rb

- Laboratório MORRO VELHO (boletins 007212/010413e 009420)

Au - Fusão à base de litargírio (carbonato de chumbo), carbonato de sódio, bórax, fubá e parafina a $1200^{\circ} \mathrm{C}$, seguido de copelação a $900^{\circ} \mathrm{C}$, ataque ácido e análise de ouro por gravimetria.

As - Método Gutzeit, fusão de amostra com bissulfato de potássio seguida de ataque ácido com $\mathrm{HCl}$, adição de $\mathrm{SnCl}_{2}+\mathrm{KI}$ metálico, e determinação através de comparação a padrões sintéticos.

- Laboratório METAMAT.

Au - Cianeto/Absorção Atômica.

Cinco amostras de veios foram analisadas por Difração de Raios-X pelo Dr. Raphael Hipólito - IGUSP, com a finalidade de checar a mineralogia observada em seções polidas. 


\section{2 - ASPECTOS FISIOGRÁFICOS E GEOMORFOLÓGICOS}

\section{1 - Hidrografia}

O rio Peixoto de Azevedo é o principal elemento hidrográfico, atravessando a área dessa pesquisa de leste para oeste (Figura 02), desenvolvendo meandros e expressiva planície aluvial de inundação.

Localmente observa-se que o canal do rio está condicionado a prováveis falhamentos de direção N-NE e W-NW. O canal principal, com cerca de $100 \mathrm{~m}$ de largura, no final da estação das chuvas, apresenta-se bastante assoreado em função de uma prática garimpeira denominada "Garimpo de Pista", que consiste em fazer o desmonte mecanizado das margens para dentro do rio, destruindo os diques marginais, desfigurando o canal e gerando em consequência um regime catastrófico de cheias.

As drenagens secundárias, tributárias dos rios Peixoto de Azevedo, Peixotinho e Braço Norte, estão representadas por diversos igarapés perenes e/ou intermitentes, por vezes configurando um padrão dentrítico a sub retangular, elaborados segundo vales suaves, configurando planices aluvionares com largura da ordem de 100 a 300 metros, que constituem os denominados baixões. Tais baixões, quando mineralizados, são os alvos principais da exploração garimpeira, e o caminho natural para a descoberta de colúvios e veios mineralizados na região.

\section{2 - Clima}

Com base na classificação de Köppen (1948), cit in Silva et al (1980), que individualizou as regiões climáticas relacionadas com a distribuição da vegetação, o clima dessa região é do tipo Am: quente e úmido (Tropical chuvoso com um pequeno período de seca e chuvas inferiores a $60 \mathrm{~mm}$, no mês mais seco do ano).

A classificação climatológica elaborada por Nimer \& Brandão (1989), considera que os processos de formação dos solos, o modelamento de relevo, os regimes hidrológicos e os padrões de drenagens estão estreitamente relacionados aos excessos e déficits de água, e esses dependem principalmente de fatores como taxa de precipitação e de evapotranspiração.

Nessa classificação, a região de trabalho, enquadrawse no clima terceiro úmido, com umidade efetiva entre $60-80 \%$, apresentando quatro meses com déficit de precipitação e deficiência hídrica, entre os meses de Maio a Agosto e sete meses com excedente hídrico entre Outubro e Abril. 



\section{3 - Geomorfologia}

A área situa-se no domínio de uma unidade geomorfológica denominada inicialmente de Pediplano Interplanáltico Serra Formosa - Cachimbo (Araújo et al. 1975), caracterizada como uma região arrasada, de relevo pouco desenvolvido, com formas mamelonares e drenagem de padrão dendrítico a dendrítico-retangular.

Melo \& Franco (1980) ao abordarem a geomorfologia da Folha Juruena ( SC-21), RADAMBRASIL (1980), caracterizaram a área, em foco, como pertencente a Depressão Interplanáltica da Amazônia Meridional, (Figura 03). Essa unidade foi descrita pelos autores como uma região rebaixada, com altimetrias variando de 200 a $300 \mathrm{~m}$, dissecada em formas convexas, estruturada principalmente sobre os granitos e gnaisses do Complexo Xingu.

Localmente observa-se um relevo suavemente ondulado, elaborado por sucessivos ciclos erosivos, sobressaindo formas estruturais, como cristas sustentadas por diques de diabásio, veios de quartzo e rochas cataclásticas. Algumas formas residuais são observadas principalmente nas regiões de interflúvios, onde feições tipo meia laranja aparecem coroadas por matacões e blocos de rochas graníticas e granodioríticas, principalmente as de fácies mais quartzosas ou porfiríticas.

Na mesopotâmia dos rios Peixoto de Azevedo e Braço Norte ocorre uma superficie aplanada, com espesso solo areno-silto-argiloso de coloração marrom avermelhado a amarelado, com frequente presença de solos transportados, evidenciados por perfis aluvionares típicos recobertos por coberturas pedogenéticas com espessura de até $10 \mathrm{~m}$. 
COMPARTIMENTAGÄO GEOMORFOLÓGICA

DO ESTADO DE MATO GROSSO
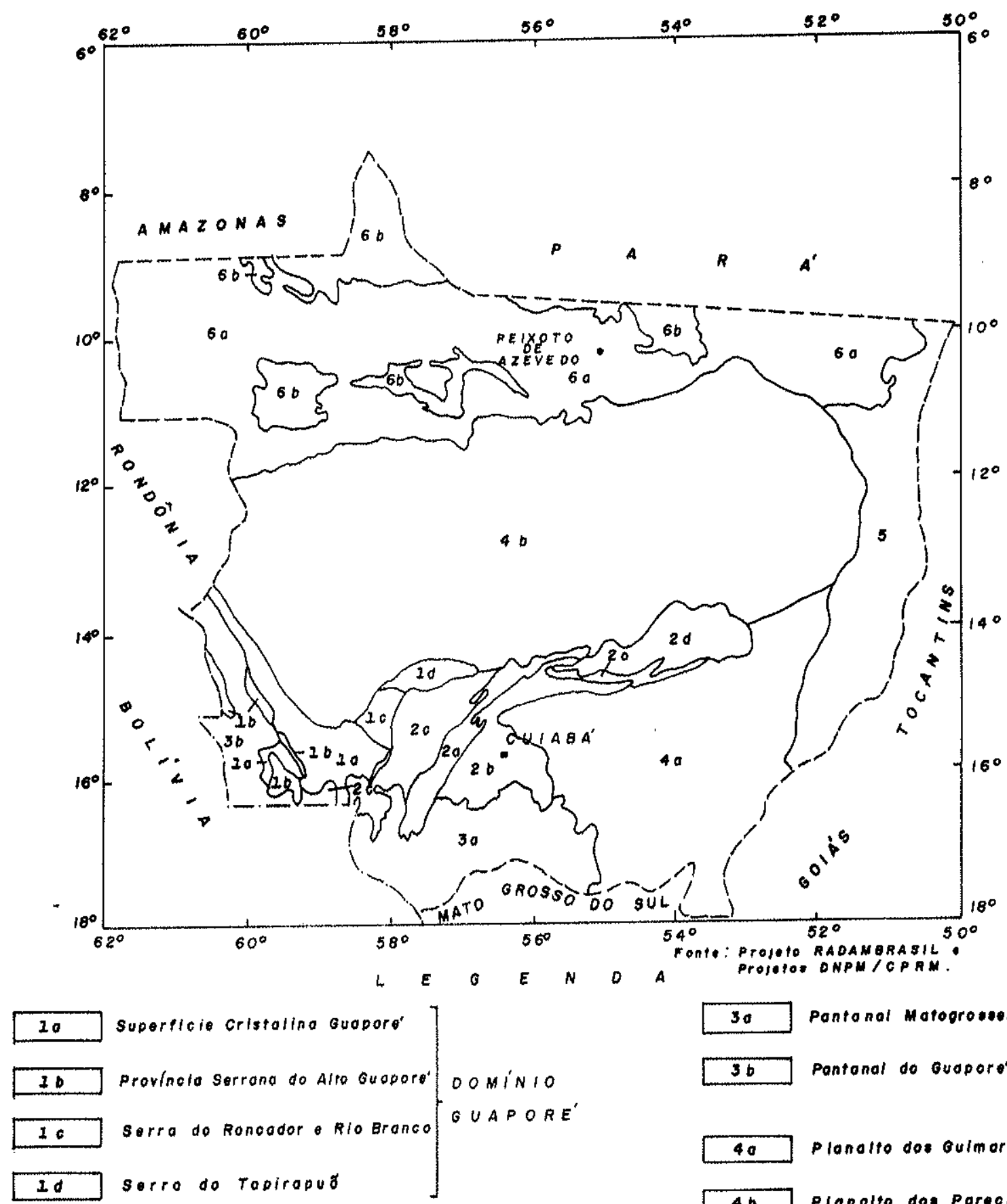

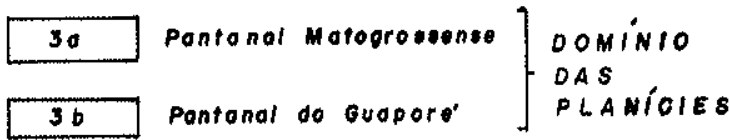
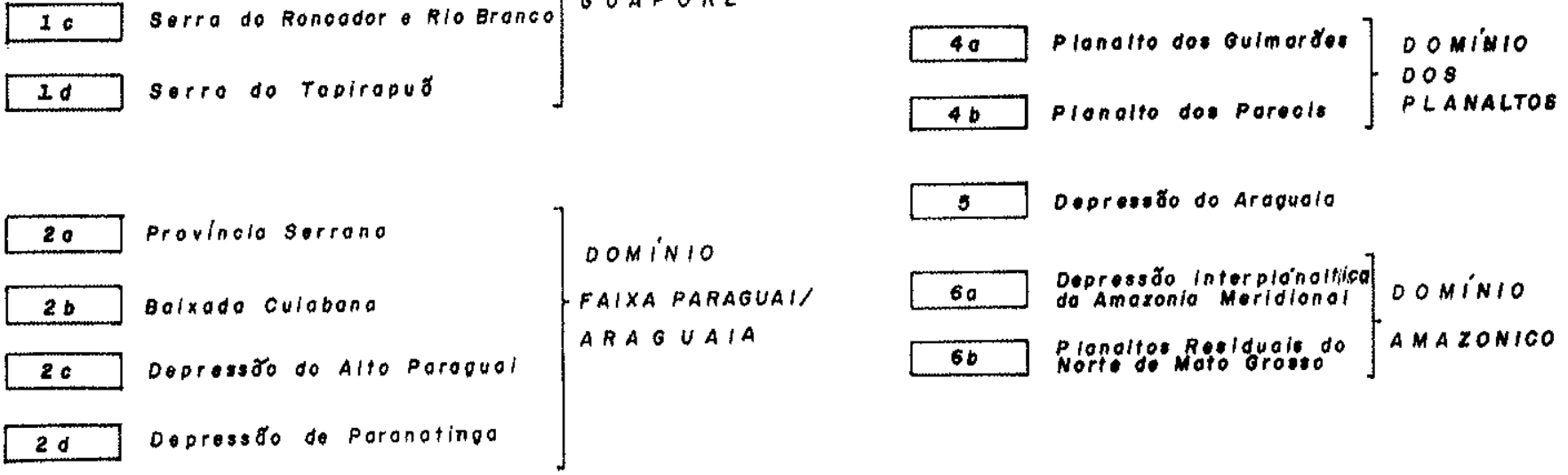

5 Depreseso do Aroguolo

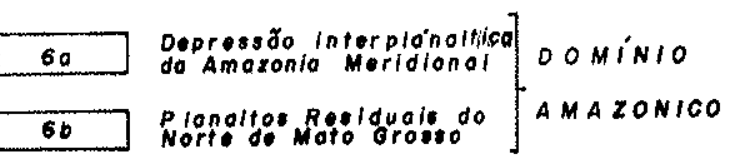




\section{3 - GEOLOGIA REGIONAL}

\section{1 - Evolução Geotectônica}

A área objeto dessa dissertação situa-se, na porção sul do Cráton Amazônico, caracterizada por Almeida et al. (1977), como Província Tapajós ou ainda, de forma mais restrita, nos limites da Subprovíncia Xingu, proposta por Amaral (1984).

Os autores que debatem a evolução tectônica da Plataforma Amazônica defendem duas linhas básicas, que representam conflitos históricos quanto à atuação ou não dos mecanismos da tectônica de placas durante o Proterozóico, e consequentemente da existência ou não dos processos de acreção no Cráton Amazônico durante essa Era.

Para a linha fixista, melhor representada pelos trabalhos de Amaral (1974), Almeida (1978), Santos e Loguércio (1982) e Amaral (1984); a Plataforma Amazônica, consolidada no fím do Arqueano, com dimensões muito próximas às atuais, seria constituída de vários complexos Arqueanos de alto grau metamórfico, com intrusivas associadas, circundados por faixas de baixo grau, geradas e/ou remobilizadas durante o Transamazônico. Os processos subsequentes seriam fundamentalmente do tipo ativação ou reativação tectônica.

Nestes termos, Amaral (1984), caracterizou três eventos principais na estruturação da Província Tapajós durante o Proterozóico, os eventos Transamazônico (2000 $\pm 200 \mathrm{Ma})$, Paraense (1700 - $1500 \mathrm{Ma})$ e Madeirense (1350 - $950 \mathrm{Ma}$ ), melhor representados nas sub-Províncias Carajás, Xingu e Madeira, respectivamente.

Segundo Cordani e Brito Neves (1982), nos modelos evolutivos propostos pela escola mobilista, essa região está inserida no âmbito da Província Amazônia Central, de idade arqueana e vocação cratônica, servindo de ante-país para a evolução de cinturões móveis, desde o Proterozóico Inferior.

Para os mobilistas, a estruturação cratônica não foi uniforme nem limitada ao evento Transamazônico, admitido como de consolidação cratônica pelos autores da linha fixista; mas sim resultante de sucessivos eventos de acreção e diferenciação crustal, através do desenvolvimento de mobile belts, a partir de um pequeno núcleo Arqueano, conforme Cordani et al. (1979), Tassinari (1981), Tassinari et al. (1987) e Teixeira et al. (1989) (Figura 04).

Cordani et al. (1979) propuseram uma evolução geotectônica para a Plataforma Amazônica baseada no desenvolvimento de três cinturões móveis, estruturados segundo a direção NW-SE, a partir de um núcleo Arqueano denominado Província Amazônia Central, a saber:

- Maroni-Itacaiunas
- Rio Negro-Juruena
- Rondoniano
2200 a $1800 \mathrm{Ma}$.

1700 a $1400 \mathrm{Ma}$.

1400 a $1000 \mathrm{Ma}$. 
Os autores citados realçam que o termo mobile belt foi utilizado no sentido de caracterizar província petrotectônica e geocronológica, portanto diferente da concep̧̧ão inicial de Anhaeusser et al. (1969).

Tassinari (1981) seguindo a concepção mobilista para a evolução da Plataforma Amazônica durante o Proterozóico, propôs a existência do cinturão Móvel Rio Negro-Juruena, situado em parte na região correspondente ao denominado Alto Estrutural Juruena-Teles Pires, de Silva et al. (1980). O autor sugere que a Província Rio Negro-Juruena resulta de um processo de acreção em um contexto de arco magmático francamente ensimático (Figura 05), com a seguinte sequência de eventos:

- Fase metamórfica principal

- Vulcanismo subsequente

- Granitogênese pós-tectônica

- Sedimentos molassóides

- Magmatismo básico terminal $\pm 1750 \mathrm{Ma}$.

$\pm 1650 \mathrm{Ma}$

$\pm 1550 \mathrm{Ma}$.

1400 a $1500 \mathrm{Ma}$.

1300 a $1400 \mathrm{Ma}$

Tassinari et al. (1987) caracterizaram o mohile belt Rio Negro-Juruena (1,75 - 1,6 Ga) ao longo da borda oeste da Província Amazônia Central, Figura 04, representado principalmente por granitos e granodioritos, frequentemente com estrutura gnáissica. Os autores associam à evolução desse cinturão o magmatismo do tipo Teles Pires, com idades 1,65 e 1,60 Ga., respectivamente.

Teixeira et al. (1989) sugerem uma evolução para a Província Rio Negro-Juruena $(1,75$ - 1,5 Ga), através do desenvolvimento de sucessivos arcos magmáticos, justapostos a massas continentais pré-existentes.

\section{2 - Regionalização Lito-Estratigráfica}

$\mathrm{Na}$ unidade geotectônica denominada Provincia Amazônia Central (Figura 04), independente dos modelos evolutivos propostos, é consenso a existência de um núcleo Arqueano, estabilizado após o desenvolvimento do Ciclo Transamazônico, e consequentemente, que os granitos gerados posteriormente a esse evento são a princípio pós tectônicos e/ou anorogênicos. A área objeto desta dissertação situa-se na extremidade sul da Provincia Amazônia Central, nas proximidades da zona limítrofe com a Província Rio Negro-Juruena. Nessa região, os efeitos da atividade granitogênica registrados durante o Proterozóico Médio, de acordo com os dados de datações radiométricas (Figura 02) foram muito intensos, obliterando as feições e estruturas pré-existentes, tornando dificil a identificação do embasamento Transamazônico.

Inúmeros trabalhos têm identificado associações graniticas no Cráton Amazônico. Durante os mapeamentos efetuados pelo projeto RADAMBRASIL, nas folhas ao milionésimo, foram identificadas diversas gerações de granitóides. Entretanto, face à escala e ao objetivo do mapeamento, esses corpos não foram suficientemente caracterizados. 


\begin{tabular}{lllll}
\hline & $E$ & $E$ & 0 & $A$
\end{tabular}

PROVINCIA

RIO NEGRO - JURUENA
PROVInc I A

AMAZONIA CENTRAL

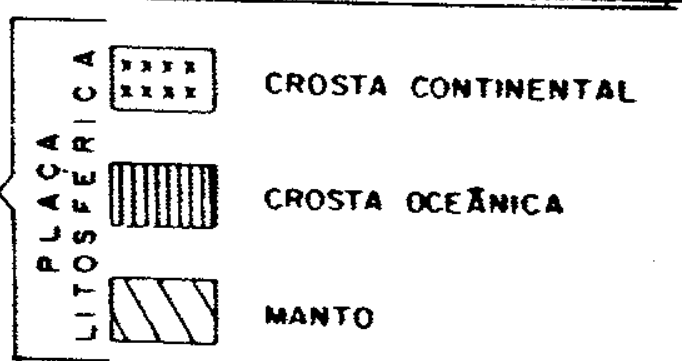

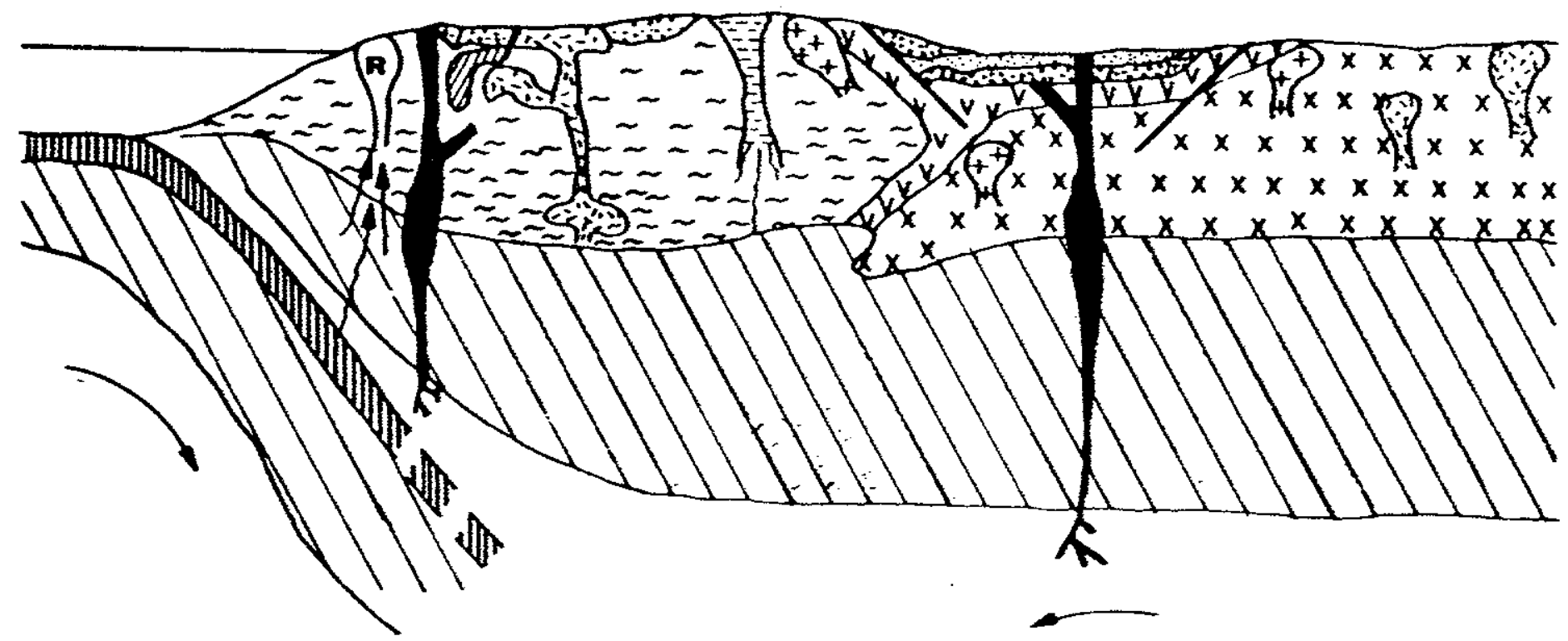

d) $1.400-1.200 \mathrm{~m} .0$
R GRANITOS TPO" RONOOMMANOS"

COMPLEXos alcalimos

VuLCANISNo BÁsico

VIIID ANORTOSITOS

SEDINENTOS EPINERITICOS

E TERRIGENOS

[萿] GRANITOS CAATOGENICOS

YXYY VULCANISMO ACIOO E IN TERME DIARIO

$t++$ GRAN TOS SUE-VULCANICOS PÓS-TECTONICOS

\section{GNAISSES E MGMATITOS} REgIONAIS

FALHAS

FIGURA O5: ESOUEMA DA EVOLUCAO OEOTECTÓNICA DA PROVIMCIA RIO NEORO- JURUEMA DASEADO MA TECTÓNICA OE PLACAS 
Para caracterizar esses corpos graniticos faz-se necessário a realização de trabalhos mais detalhados, em termos de relação estratigráfica, aspectos texturais e estruturais, associados com dados petroquímicos e geocronológicos, que permitam estabelecer o contexto de geração, evolução e diferenciação, bem como compreender os mecanismos de posicionamento dessas intrusões.

Os trabalhos publicados por Dall'Agnol (1980, 1982), Santos (1982), Santos e Loguércio (1984), Dall'Agnol et al. (1984, 1986, 1987), Gastal (1988), Medeiros e Dall'Agnol (1988), Macambira et al. (1990), entre outros, sintetizam a evolução dos conhecimentos e o panorama atual, sobre a granitogênese neste segmento cratônico,

Em termos de unidades lito-estratigráficas regionais no âmbito da Província Amazônia Central, o trabalho publicado por Macambira et al. (1990), sintetiza a atividade granitogênica Pré-Cambriana, e portanto será utilizado como referência para a região de Peixoto de Azevedo. Estes autores distinguem três grandes grupos de granitóides posicionados do Arqueano ao Proterozóico Médio, a saber:

- Granitóides Arqueanos

- Granitóides Transamazônicos

- Granitóides Anorogênicos do

Proterozóico Médio
$>2.500 \mathrm{Ma}$

$\sim 2.000 \mathrm{Ma}$

$1600-1750 \mathrm{Ma}$

A proposta apresentada, apesar de baseada em poucos dados petrológicos e geocronológicos, cumpre o papel de agrupar os grandes conjuntos relativos aos principais eventos formadores de rocha.

No momento, a maior dificuldade refere-se à individualização e caracterização dos granitóides do Proterozóico Médio, uma vez que existem dezenas de denominações e interpretações diversas quanto a natureza, ambiente de geração e relação de contato desses corpos, caso dos trabalhos já citados de Silva et al (1974, 1980), Santos et al (1975), Leal et al (1978), Bittencourt et al. (1981), Cunha et al. (1981), Santos (1982), Santos e Loguércio (1984), Dall'Agnol (1982, $1986)$, e outros.

\subsection{1 - Granitóides Arqueanos}

Conforme Dall'Agnol et al. (1987) esses tipos de granitóides já foram identificados na região da Serra do Navio - Amapá, Altamira - Pará e na região de Rio Maria - Pará.

Segundo esses autores, a região de Rio Maria - PA é um típico terreno granito-greenstone, com granitóides metamorfisados afetados por estruturas miloníticas, contendo restos de sequências vulcano-sedimentares e mineralizações de ouro. O Granodiorito Rio Maria ocorre em uma vasta área, muito superior a área de ocorrência das sequências de gnaisses e greenstones. Os autores citam a 
existência de variações faciológicas no Granodiorito Rio Maria, com hornblendabiotita monzogranitos, biotita leucogranodioritos e biotita leucomonzogranitos. No diagrama QAP (Figura 06), essas rochas estão concentradas no campo da série granodiorítica cálcio-alcalina, evidenciando a importância deste magmatismo no Arqueano dessa região.

Macambira et al. (1990) citam como exemplos de Granitóides Arqueanos, o Trondhjemito Mogno, o Tonalito Parazônia e o Granodiorito Cumaru, aflorantes na Provincia Mineral de Carajás, sudeste do Pará.

Os dados geocronológicos podem ser verificados na Tabela 01, (Página 21), obtida do trabalho de Macambira et al (1990), com as idades evidenciando um importante evento magmático entre 2680 e $2560 \mathrm{Ma}$, e as razões iniciais sugerindo a uma origem a partir da base da crosta e/ou manto superior.

Souza et al. (1979) caracterizaram nos limites da reserva garimpeira de Peixoto de Azevedo - MT, os Granitos do Nhandu, individualizados do Complexo Xingu por suas características estruturais e texturais. São granitóides isótropos, com megacristais ovóides de feldspato alcalino imersos em uma matriz de composição granodiorítica a tonalítica, que ocorrem em estreita associação com os gnaisses do Complexo Xingu.

\subsection{2 - Granitóides Transamazônicos}

Os granitóides correlacionados ao evento Transamazônico, posicionados no limite Arqueano-Proterozóico inferior, conforme Santos e Loguércio (1984), não estão suficientemente mapeados, nem datados, para permitir um posicionamento inquestionável. Inúmeros trabalhos realizados no Cráton Amazônico têm identificado corpos graníticos que via de regra, apresentam estreita asșociação com terrenos granito-gnáissicos, presumivelmente Arqueanos.

Embora devam existir amplas regiões afetadas pelo ciclo Transamazônico, os granitóides associados a esse evento não têm sido objeto de estudos mais detalhados (Macambira et al, 1990).

Entre os granitóides tidos como Transamazônicos, pode-se citar os Granitóides Água Branca, de Veiga Jr. et al. (1979, in Dall'Agnol et al, 1980) e Juruena, de Silva et al. (1974), destacando-se esse último por aflorar nas proximidades da área do presente trabalho.

Segundo Dall'Agnol et al. (1987), o Granitóide Água Branca é um dos complexos mais conhecidos de Granitóides Transamazônicos, aflorantes no âmbito da Província Amazônia Central, na região noroeste do Estado do Pará. Ocorrem em grandes batólitos, são rochas isótropas a localmente foliadas ou bandadas, de coloração cinza a róseo. Entre os litótipos predominantes, cita-se monzogranitos e granodioritos, e subordinadamente sienogranitos, quartzo monzonitos, quartzo monzodioritos, quartzo dioritos e tonalitos. 


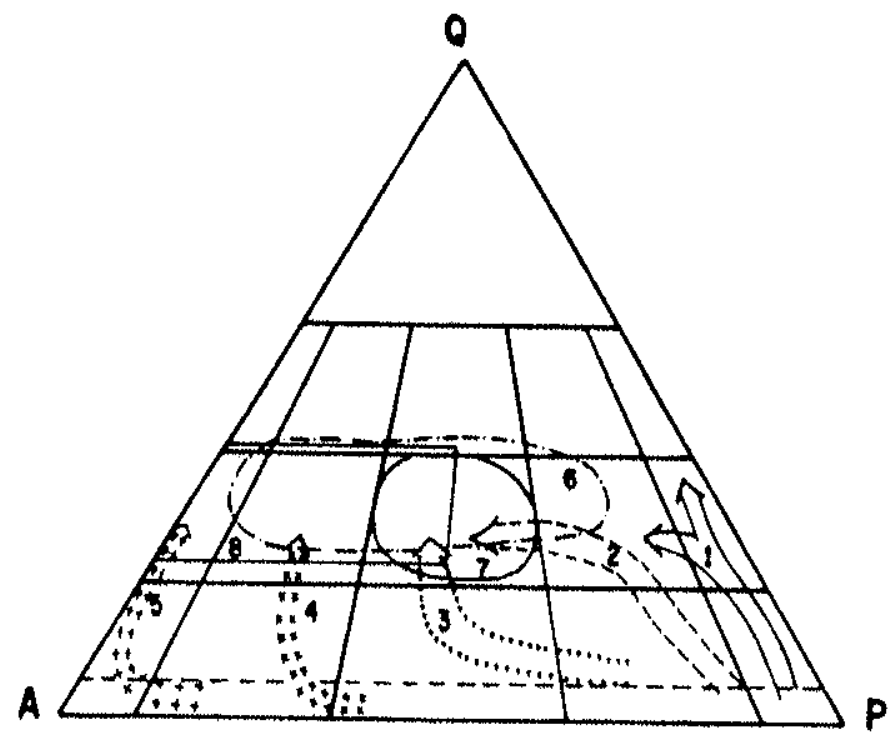

Figura 06. Diagrama QAP contendo os principais trends das séries graníticas da região norte do Brasil, comparado com os limites propostos por Lameyre \& Bowden (1982) e Bodwen et al. (1984).

Fonte: Dall'Agnol et al. (1987) - modificado.

1. Série tonalítica ou trondhjemítica calcio-alcalina.

- Granitóides sódicos arquenos do Amapá e da região de Altamira.

- Sequência gnaíssica mais antiga da região de Rio Maria.

2. Série granodiorítica calcio-alcalina.

- Granodiorito Rio Maria (arqueano).

- Granitóide Água Branca (transamazônico).

3. Série Monzonítica sub*alcalina.

- Granitóides do tipo biotita granito com anfibólio e esfeno (SABG) da província Rio Negro (proterozóico médio).

- Alguns tipos de granitos Rapakivi anorogênicos.

4. Série Potassica Aluminosa

- Granitos anorogênicos tipo A das províncias Amazonica Central, Juruena e Rondonia.

5. Série Sódica Alcalina

- Sienito Canamã da província Juruena.

- Alguns tipos de granitos anarogênicos tipo A.

6. Série Granito Crustal

- Granitóides a duas micas ( $2 \mathrm{MG}$ ) da província Rio Negro.

7. Campo definido por 27 amostras do granito anorogênico Jamon (proterozóico médio).

8. Campo definido pelas fáceis dominantes dos granitos anorogênicos tipo A. 
Jorge João et al. (1985, in Dall'Agnol et al, 1987), sugerem que os granitóides tipo Água Branca foram gerados a partir de um magma cálcio alcalino, com alto alumínio; em um modelo colisional, esses granitóides poderiam corresponder a uma atividade reflexa no núcleo cratônico.

Silva et al.(1974), individualizaram do Complexo Xingu alguns corpos graníticos de natureza homogênea, remobilizados e em estreita associação com os granitos e gnaisses do Complexo Xingu, aos quais denominaram Granito Juruena. As descrições petrográficas efetuadas por Souza et al.(1979) dos granitos Juruena, identificados nas proximidades da cidade de Alta Floresta, compreendem rochas graníticas e granodioríticas, isótropas, leucocráticas, de coloração cinza claro, geradas a partir de fusões parciais em núcleos reomórficos dentro do Complexo Xingu.

Os dados geocronológicos disponíveis sobre os citados granitóides podem ser observados na Tabela 02 , (Página 21).

\subsection{3 - Granitóides do Proterozóico Médio}

Os granitóides anorogênicos admitidos do Proterozóico Médio ocupam expressiva área nos limites da Província Amazônica Central. A constatação da existência de pelo menos uma geração de granitos, em principio, relacionados com - evento vulcanogênico denominado Uatumă serviu como referencial para as primeiras tentativas de subdivisão.

Santos (1982) e Santos e Loguércio (1984) distinguem dois grupos de granitos anorogênicos; um, cogenético às vulcânicas Uatumã, representado por granitos tipo Maloquinha, Serra do Carajás, etc. e outro grupo, representado por granitos tipo Velho Guilherme, Serra da Providência e Teles Pires, mais jovens e que afetam as Coberturas Sedimentares Tipo Beneficente .

Dall'Agnol et al.(1987) e Macambira et al.(1990) situaram a atividade granitogênica de idade Proterozóico Médio no intervalo entre 1900-1400 Ma e 1750-1600 Ma, respectivamente. Os autores identificaram dois grupos principais de granitóides; um, predominantemente alcalino, similar aos do tipo A, e o outro, pertencente a granitos da série com magnetita, com caracterização químicas análogas aos granitos do tipo I (Caledoniano).

Os autores realçam que essa comparação, de granitos gerados em regiões e contextos geológico evolutivos distintos não implica em dizer que exista uma perfeita identificação entre ambos, mas sim que existem similaridades petrológicas.

\section{Granitos Similares aos do Tipo A}

Representados com maior frequência, por biotita sienogranitos com variação para monzogranitos e álcali-feldspato granitos. Nos termos menos evoluidos, é citado a presença de granitos rapakivi, sienitos e quartzo sienitos; 
fácies peralcalinas ocorrem mais raramente. São rochas leucocráticas, predominantemente sub solvus, equigranulares, com a estrutura porfiritica restrita às fáceis de textura rapakivi. Processos tardios e pós magmáticos são expressivos nos termos mais diferenciados, com formação da albita, fluorita, topázio e moscovita, em contexto de apogranitos.

Dall'Agnol et al.(1987) identificaram diferenças marcantes no quimismo desses granitos. De um lado, os biotita granitos, com teores elevados de $\mathrm{Rb}$, Sn e F, e teores baixos de $\mathrm{Sr}$ e Ba, devem representar granitos especializados a estanho, produtos oriundos de magmas extremamente diferenciados. Do outro lado, estão, anfibólio granitos, granitos rapakivi e sienitos, apresentando teores de elementos traços compatíveis com os granitos e sienitos normais.

Segundo os autores supracitados, podem ser enquadrados como granitóides similares ao tipo A os Granitos Serra dos Carajás, Pojuca, Serra do Acari, Madeira, Água Boa, Seringa, Cigano, Antônio Vicente, Velho Guilherme, Mocambo, Porquinho e Teles Pires, entre outros.

\section{Granitos a Magnetita, Análogos ao tipo I Caledoniano}

DallÁgnol et al.(1987) citam como exemplo mais representativo dessa tipologia o Granito Jamon, com as seguintes caracteristicas que o distinguem dos granitos tipo A :

- Homogeneidade composicional, com predomínio de monzogranitos;

- Sequiência de cristalização bem definida;

- Transposição entre as fáceis dominantes;

- Composição química menos evoluída;

-Transformações tardi a pós-magmáticas pouco expressivas;

- Susceptibilidade magnética muito elevada; e

- Ausência de significativas mineralizações estaníferas.

\section{Geocronologia}

Uma das maiores limitações à utilização extensiva de datações geocronológicas para a caracterização da atividade granitogênica no âmbito da Província Amazônia Central, e em especial para os granitos do Proterozóico Médio, decorre da inexistência de mapeamentos em escala apropriada, que permitam a individualização de corpos ou mesmo fases magmáticas específicas.

Desta forma, a maior parte dos estudos disponiveis referem-se a isócronas de referência, na maioria das vezes resultantes de amostras não cogenéticas. Apresentam-se na Tabela 03, (Página 21), os dados geocronológicos disponiveis para os granitos e vulcânicas de idade Proterozóico Médio, da região no âmbito da Folha SC.21-Z-B (Vila Guarita). Para melhor compreensăo do quadro geocronológico foram indicados, na Figura 02 os pontos de coleta de amostras com as datações efetuadas no trabalho de Tassinari (1981). 
Dall'Agnol et. al. (1987), sugerem a nivel da província Amazônica Central, que os granitos tipo A são oriundos da anatexia da crosta granulítica, enquanto os granitos tipo I, provêm da anatexia das rochas ígneas pertencentes aos terrenso granitos gresntone. Os autores admitem que algumas suítes com características inerentes aos granitos portadores de magnetita (caso dos granitos Jamon e Musa), podem ter sua origem relacionada a processos ocorrentes nas províncias vizinhas, e de forma menos provável, gerados em contexto de zonas de colisão continental ou subducção.

Macambira et al. (1990) observam que as idades $\mathrm{Rb} / \mathrm{Sr}$ encontradas nos granitos do Proterozóico Médio (Tabela 03), entre 1750 e $1600 \mathrm{Ma}$, com razões isotópicas iniciais entre 0,7068 a 0,7150 , posicionam esses granitos no campo característico de materiais com importante contribuição crustal. Com relação ao ambiente geotectônico de geração dos granitos do Proterozóico Médio, os autores admitem que os mesmos possuem geralmente características caincidentes com os granitos intraplacas, sendo anorogênicos ou, menos provavelmente, pós Tectôncicos.

\subsection{4 - Vulcano-Plutonismo Uatumã}

O Proterozóico Médio da Plataforma Amazônica registra um importante magmatismo de natureza ácida a intermediária, com piroclásticas, sedimentos associados e granitogênese comagmática, denominado regionalmente de grupo Uatumã. $O$ arrefecimento da atividade vulcânica foi acompanhado pelo desenvolvimento de expressivas coberturas plataformais, em bacias do tipo graben, representadas pelos grupos Beneficente, Caiabis e Gorotire, no âmbito da Província Amazônia Central, segmento meridional.

Dada a extensão e amplitude temporal do vulcano-plutonismo, durante o período entre 1900 a $1550 \mathrm{Ma}$, existem divergências quanto ao posicionamento e o relacionamento dos diversos conjuntos vulcano-plutônicos e sedimentos associados.

Santos et al. (1975) caracterizaram na área da Folha Tapajós, SB-21, os granitos tipo Maloquinha, como uma fase terminal do magmatismo Uatumã, intrusivo nas vulcânicas da Formação Iriri.

Silva et al.(1980) subdividiram o grupo Uatumã nos limites da Folha Juruena, SC.21, em Formação Iriri e granitos tipo Teles Pires, posicionando o conjunto vulcano-plutônico no intervalo entre 1700-1550 Ma.

Cunha et al.(1981) subdividiram o Grupo Uatumã na Folha Tocantins, SC.22, em Formação Iriri e Suite Intrusiva Rio Dourado.

Santos (1984) e Santos e Loguércio (1984) posicionaram como Super Grupo Uatumã as sequências vulcânicas não metamorfisadas, com idades variando entre 1900 e $1700 \mathrm{Ma}$, e quimismo calci-alcalino comum, denominadas localmente de Surumu (Roraima), Iricoumé (NE do Amazonas e NW do Pará), Iriri (SE do 


\begin{tabular}{|c|c|c|c|c|c|}
\hline \multicolumn{6}{|c|}{$\begin{array}{l}\text { Tabola } 1 \text { - PRINCIPAIS DADOS GEOCRONOLÓGICOS DISPONIVEIS PARA OS GRANITOIDES AROUEANOS DA PROVÍNCIA } \\
\text { AMAZONIA CENTRAL BRASILEIRA }\end{array}$} \\
\hline UNIDADE & LITOLOGIA & METODO & IDADE (Ma) & (87sr/86sr) & Referencia \\
\hline $\begin{array}{l}\text { Granodiorito } \\
\text { Rio Maria o } \\
\text { Fazenda Wata } \\
\text { Geral }\end{array}$ & Granodiorito & $\begin{array}{l}\text { Rb-Sr em R.T. } \\
\text { Num. de pontos: } 7\end{array}$ & $2.660 \div 40$ & 0.7009 & $\begin{array}{c}\text { Montalvão et al. } \\
\text { (1984) }\end{array}$ \\
\hline $\begin{array}{l}\text { Granodiorito } \\
\text { Rio Maria }\end{array}$ & Gran & $\begin{array}{l}\text { Rb-Sr em R.T. } \\
\text { Num. de pontos: } 6\end{array}$ & $2.564 \pm 63$ & 88 & Gasta! (1987) al. \\
\hline $\begin{array}{l}\text { Associaçá } \\
\text { Asonal itgo } \\
\text { Trondh jemitica }\end{array}$ & $\begin{array}{l}\text { Tonal ito } \\
\text { Trondh je }\end{array}$ & $\begin{array}{l}\text { Rb-Sr em R.T. } \\
\text { Num, de pontos: } 6\end{array}$ & $2.614 \pm 120$ & 0.7025 & Macambira et al. \\
\hline $\begin{array}{l}\text { ondh jemi to } \\
\text { gno }\end{array}$ & Trondh jem i to & $\begin{array}{l}\text { Rb-Sr em R.T. } \\
\text { Num. de pontos: } 11\end{array}$ & $2.680 \pm 60$ & 0.7017 & Montal (19äo et al. \\
\hline $\begin{array}{l}\text { ranodiorito } \\
\text { umaru }\end{array}$ & Grano & $\begin{array}{l}\text { Rb-Sr em R.T' } \\
\text { Num. de pontos: } 6\end{array}$ & $2.543 \pm 53$ & 0.70311 & Lafon 1980 Mcambira \\
\hline
\end{tabular}

* Fonte: Obtido e simplificado de Macambira ot al. (1980)

Tabola 2 - PRINCIPAIS DADOS GEOCRONOLOGG COS CITADOS COMO REFERENTES A GRANITÓIDES DE IDADE

\begin{tabular}{|c|c|c|c|c|}
\hline UNIDADE & LOCALIZACCÃO & IDADE Rb/Sr (Ma) & $\left(\mathrm{Sr}^{87} / \mathrm{Sr} r^{80}\right) \mathrm{i}$ & Roterência \\
\hline $\begin{array}{l}\text { Adamel ito } \\
\text { Jamanx im }\end{array}$ & $\begin{array}{l}\text { Tapajós } \\
\text { SB. } 2 \gamma_{-Y \rightarrow B}\end{array}$ & $1917 \div 72$ & - & Pessqa et al. \\
\hline $\begin{array}{l}\text { Granito } \\
\text { Jamanxim }\end{array}$ & $\begin{array}{l}\text { Tapajós } \\
\text { SB. } 2]_{-Y}\end{array}$ & $1965 \pm 125$ & - & Pessog et al. \\
\hline \begin{tabular}{|l} 
Monzograni to \\
Parauani
\end{tabular} & $\begin{array}{c}\text { Tapajós } \\
\text { SB. } 21-\uparrow-\mathrm{B} / \mathrm{C}\end{array}$ & $\begin{array}{r}1925 \pm 76 \\
2018 \pm 65 \\
\end{array}$ & - & Bizinglla et al. \\
\hline $\begin{array}{l}\text { Granito } \\
\text { Parauani }\end{array}$ & $\begin{array}{l}\text { Tapajós } \\
\text { SB, } 21-Y-B\end{array}$ & $\begin{array}{r}1962 \div 57 \\
1973 \div 56 \\
\end{array}$ & - & Bizing(la $(1980)^{\text {et al. }}$ \\
\hline $\begin{array}{l}\text { Granito } \\
\text { Juruena }\end{array}$ & $\begin{array}{l}\text { Juruena } \\
\text { SC. } 21\end{array}$ & $1935 \pm 90$ & - & Tassinari ${ }_{(1978)}^{\text {Teixoira }}$ \\
\hline $\begin{array}{l}\text { Adamel ito } \\
\text { Agua Branca }\end{array}$ & SA. 20 & $1910 \pm 47$ & 0.7023 & $\begin{array}{l}\text { Jorge joão et. al } \\
\text { Y1985 ing Macambira } \\
\text { et al. (1990) }\end{array}$ \\
\hline
\end{tabular}

* Fonte: Compilado com modifi caçóes de Santos e Loguercio (1984)

\begin{tabular}{|c|c|c|c|c|}
\hline \multicolumn{5}{|c|}{$\begin{array}{r}\text { Tabela } 3 \text { - PRINCIPAIS DADOS GEOCRONOLÓGICOS SISPONIVEIS NA FOLHA SC 21-Z-B (Vila Guarita) } \\
\text { PARA OS GRANTTSSE VULCANICAS DE IDADE PROTEROZZICA }\end{array}$} \\
\hline UNIDADE & LITOLOGIA & IDADE Rb/Sr (Ma) & $\left(\mathrm{Sr}^{87} / \mathrm{Sr}^{86}\right) \mathrm{i}$ & Referência \\
\hline $\begin{array}{l}\text { Complexo } \\
\text { Xingu }\end{array}$ & $\begin{array}{c}\text { Granodior ito } \\
\text { porfiriro } \\
\text { pt. } 15\end{array}$ & (A) $1860 \pm 94(2)$ & 0.704 & Tassinari (1978) Toixeira \\
\hline $\begin{array}{l}\text { Comploxo } \\
\text { Xingu }\end{array}$ & $\begin{array}{c}\text { Adamel ito } \\
\text { Gramofirico } \\
\text { pt. } 06 \text { Bi }\end{array}$ & (B) $1743 \pm 42(2)$ & 0.702 & Tassinari $(1978)^{\text {Teixeira }}$ \\
\hline $\begin{array}{l}\text { Granito Teles } \\
\text { Pires }\end{array}$ & $\begin{array}{l}\text { Migrograni to } \\
\text { porfirg } \\
\text { pt. 25. 2/23. } 1\end{array}$ & $1619 \pm 71(1)$ & - & Tassinar (1978) \\
\hline \begin{tabular}{|l|} 
Granj to Toles \\
Pires \\
\end{tabular} & $\begin{array}{l}\text { Adame } 1 \text { ito } \\
\text { pt } 19 A 1 / 33\end{array}$ & $\begin{array}{l}1608 \pm 30(1) \\
1518 \div 50(1) \\
\end{array}$ & - & Tassinari (1978) Toixaira \\
\hline $\begin{array}{l}\text { Granito Toles } \\
\text { Pires }\end{array}$ & $\begin{array}{l}\text { Granodior i to } \\
\text { pt } 45\end{array}$ & $1513 \pm 41(1)$ & - & Tassinari $(1978)$ Teixeira \\
\hline $\begin{array}{l}\text { Granito Toles } \\
\text { Pires }\end{array}$ & $\begin{array}{l}\text { Granitos Subm } \\
\text { Vulcanicos }\end{array}$ & $1550 \quad(2)$ & - & $\begin{array}{l}\text { Basei (1974) (ni } \\
\text { Silva ot al. (1980) }\end{array}$ \\
\hline Vu|ainjicas & $\begin{array}{l}\text { Riolito } \\
\text { pt.22. }\end{array}$ & $\begin{array}{r}1453 \pm 36(1) \\
1676 \pm 36(2) \\
\end{array}$ & 0.704 & Tass inari $(1978)^{\text {Toixeira }}$ \\
\hline $\begin{array}{c}\text { Granito Toles } \\
\text { Pires }\end{array}$ & anitos & $1602 \pm 30(2)$ & 0.707 & Tassinari $(1978)^{\text {Teixeira }}$ \\
\hline $\begin{array}{l}\text { Vulcânicas } \\
\text { Teles pires }\end{array}$ & Vulcânicas & $1561 \pm 38(2)$ & 0.705 & $\begin{array}{c}\text { Basei (1977) in: } \\
\text { Tass inari et al a } \\
\text { (1978) }\end{array}$ \\
\hline
\end{tabular}

* Obs.: (1) |sócronas pontuais

(2) sócronas de referência

(A) Socrona relativa a porçăo or iental da Folha $S C-21$, 
Amazonas e SW do Pará), Dalbana (Suriname), Caiçara (Venezuela) e Iwokrama (Guiana); estratigraficamente recobertas por cobertura sedimentares tipo Roraima, Gorotire, Urupi e Beneficente. A fase final do magmatismo Uatumã estaria representada por granitóides tipo Maloquinha, Mapuera e Saracura.

Santos (1984) realizou um estudo petroquímico em 239 amostras do Super Grupo Uatumã, provenientes de toda a plataforma Amazônica, onde identificou doze tipos litológicos principais:

$\begin{array}{ll}06 \text { quartzolitos } & 06 \text { ortoclásio-quartzo-traquitos } \\ 18 \text { ortoclásio-riolitos } & 17 \text { quartzo-latitos } \\ 42 \text { riolitos } & 48 \text { riodacitos } \\ 06 \text { ortoclásio-traquitos } & 31 \text { dacitos } \\ 12 \text { quartzo-traquitos } & 21 \text { latitos } \\ 07 \text { traquitos } & 23 \text { andesitos }\end{array}$

Com relação aos dados petroquímicos, nota-se nos diagramas classificatórios as tendências evolutivas a partir de um magma primário de composição andesítica, com enriquecimento progressivo em álcalis e sílica, evidenciando claramente a natureza subalcalina das vulcânicas Uatumã.

Para Souza et al. (1979) o Grupo Uatumă está representado além dos termos plutônicos (Granito Teles Pires) e vulcânicos (Formação Iriri), por uma unidade sedimentar denominada informalmente Sedimentos do Braço Sul, representada por ortoquartzitos, arenitos arcoseanos, arenitos lito-feldspáticos e grauvácas líticas.

A fase terminal do magmatismo Uatumã compreende inúmeros corpos graníticos comagmáticos sub-vulcânicos, de caráter, intra-placa, identificados em inúmeros trabalhos desenvolvidos na plataforma amazônica.

No domínio da Província Amazônica Central merecem destaque os granitos Maloquinha e Teles Pires.

\section{Granito Maloquinha}

Santos et al. (1975) caracterizaram o granito Maloquinha, na mesopotâmia Tapajós-Xingu, como corpos de natureza sub-vulcânica, intrusivos nas rochas do Complexo Xingu e do Grupo Uatumã. Segundo Santos e Loguércio (1984), os granitóides tipo Maloquinha, com idades próximas a $1800 \mathrm{Ma}$., são comagmáticos com as vulcânicas Uatumã e correlacionáveis ao granito Serra dos Carajás. Petrograficamente, predominam tipos como alaskitos, biotita-granitos e granófiros.

Segundo Bettencourt et al. (1981), os granitóides anoro-gênicos da Suite Intrusiva Maloquinha aflorantes na região do Tapajós-Jamanxim estão posicionados segundo lineamentos regionais, constituindo mais de 40 corpos irregulares, com diâmetros variando entre 3 e $33 \mathrm{Km}$. Os tipos petrográficos mais comuns variam de biotita-granitos a quartzo-sienitos. 


\section{Granito Teles Pires}

Silva et al. (1974) adotaram a denominação Granito Teles Pires para as intrusões sub-vulcânicas, com feições circulares e tendência alaskítica, cogenéticas à Formação Iriri do Grupo Uatumã.

Silva et al. (1980) citam a faixa ao longo da borda sul da Serra do Cachimbo como a região com maior presença de granitos sub-vulcânicas do tipo Teles Pires, admitindo para esses granitos uma isócrona de referência com $1548 \pm$ $28 \mathrm{Ma}$. Os tipos petrográficos mais comuns são granitos e microgranitos, com texturas gráfica, micrográfica, porfirítica e rapakivi.

Souza et al. (1979) caracterizaram todos os maciços graníticos tipo Teles Pires como rapakivi, com predominio de álcali-granitos de coloração rosaavermelhada, hololeucocráticos e isótropos, com ausência de qualquer feição cataclástica.

Tassinari (1981) considerou os Granitos Teles Pires como uma atividade magmática pós-tectônica, sub-vulcânica e que acompanha a distribuição das rochas vulcânicas nos limites da Província Rio Negro-Juruena.

Maraui e Veiga (1985), em uma síntese sobre a geologia da mina de Novo Planeta, na região de Alta Floresta - MT, identificaram um corpo intrusivo, tipo Teles Pires, com dimensões em torno de $30 \times 10 \mathrm{Km}$, alongado na direção E$\mathrm{W}$, segundo a orientação dos grandes lineamentos regionais (no caso, o lineamento São João da Barra - Teles Pires). Litologicamente, o corpo granítico é constituído de biotita granitos róseos, porfíiticos, com xenólitos de rocha vulcânica ácida. A idade foi admitida como referente ao evento Teles Pires, com cerca de $1550 \mathrm{Ma}$.

Os trabalhos de Silva et al. (1974), Souza et al. (1979) e Maraui e Veiga (1985) posicionaram o Granito Teles Pires como mais antigo que as coberturas tipo Beneficente. Santos e Loguércio (1984), baseados em dados geocronológicos relativos ao Diabásio Crepori, com idade ( $\mathrm{K} / \mathrm{Ar}$ ) da ordem de $1600 \mathrm{Ma}$, observado por Bizinella et al (1980; in Santos e Loguércio, 1984) afetando os sedimentos do Grupo Beneficente, posicionaram o Granito Teles Pires acima do Grupo Beneficente, correlacionando-o a uma terceira geração de granitos cratogênicos.

\subsection{5 - Grupo Beneficente}

Silva et al. (1980) descreveram o Grupo Beneficente como um pacote sedimentar, marinho a continental, preenchendo os Grabens do Cachimbo e da Serra Formosa, com ausência de metamorfismo regional e com as seguintes litologias principais: arenitos ortoquartzíticos, arcóseos, arenitos feldspáticos, siltitos, folhelhos, cherts, argilitos, conglomerados polimíticos e calcários. Os autores descrevem ainda litologias como quartzítos, xistos, metarenitos, metarcóseos, associados a metamorfismo dinâmico, nas adjacências de zonas de falhas e hornfels em eventuais zonas de contato com intrusões graníticas. 
Carvalho e Figueiredo (1982) descreveram o Grupo Beneficente, na região do Domo do Sucunduri, como um pacote sedimentar, com espessura da ordem de $1100 \mathrm{~m}$, com conglomerado polimítico basal e seis unidades clastoquímicas.

Bizinela et al.(1980; in Santos e Loguércio, 1984) afirmam que o Grupo Beneficente é cortado por diques e sills de vulcânicas básicas, denominadas Diabásio Crepori, com idade (K/AR) de $1565 \pm 50 \mathrm{Ma}, 1599 \pm 37 \mathrm{Ma}, 1694 \pm 28$ $\mathrm{Ma}, \mathrm{e} 1365 \pm 72 \mathrm{Ma}$.

\subsection{6 - Magmatismo Básico}

O magmatismo pré-cambriano anorogênico de natureza básica a alcalina, está representado na região por corpos na forma de diques, sills, stocks e pequenos derrames, reconhecidos e citados em inúmeros trabalhos.

Teixeira (1987), baseado em cerca de 100 determinações radiométricas $\mathrm{K} / \mathrm{Ar}$ e $\mathrm{Rb} / \mathrm{Sr}$ em rochas básicas e alcalinas da região amazônica, estabeleceu a existência de 4 conjuntos vulcânicos principais para as rochas básicas, a saber:

- Um conjunto mais antigo, com maior concentração de idades no intervalo de tempo entre 1950 - $1850 \mathrm{Ma}$, identificado no interior da Província Amazônica Central, e de forma mais restrita no interflúvio Tapajós-Jamanxim. Foi interpretado como uma atividade magmática básica contemporânea à fase póstectônica do ciclo Transamazônico;

- Um segundo conjunto com idades entre 1500 - $1300 \mathrm{Ma}$, que segundo o autor, sugere uma possível atividade anorogênica vinculada ou reflexa ao desenvolvimento da Faixa Móvel Rio Negro - Juruena;

- O terceiro conjunto mostra idades mais dispersas, e o autor sugere um prolongado periodo de atividade magmática, com maior intensidade no periodo entre 1250 - $1050 \mathrm{Ma}$. Esse conjunto está associado à reativação de grandes zonas de fraqueza regionais;

- O conjunto mais recente localiza-se preferencialmente em Rondônia, com idades entre 1050 e $850 \mathrm{Ma}$, e relaciona se ao magmatismo terminal do Evento Magmático Rondoniano (1400 - $1000 \mathrm{Ma})$.

\subsection{7 - Coberturas Fanerozóicas}

Os registros do Proterozóico superior na região são escassos, segundo a literatura. O Fanerozóico, representado neste segmento cratônico, pela Bacia do Alto Tapajós (Santiago et al, 1980), admitida de idade Paleozóica (não diferenciado), evidencia a existência, ainda no Paleozóico, de depocentros, ao longo do Graben do Cachimbo, que muito provavelmente se estenderam até a região de deposição da Formação Parecis, também de evolução Páleo-Mesozóica, segundo Siqueira (1988). 


\subsection{8 - Coberturas Cenozóicas}

Com as informações disponiveis, não é possivel estabelecer em que tempo ocorreu a inversão do relevo configurando o atual posicionamento que confere aos Grabens do Cachimbo, a norte, e do Caiabis, ao sul, uma situação de planaltos margeando a Depressão Interplanáltica da Amazônia Meridional - Alto Estrutural Juruena Teles Pires, de Silva et al. (1980). É notório que até chegar ao atual nível de aplainamento e dissecação desta Depressão Interplanáltica, com desníveis relativos entre as unidades citadas da ordem de 250 metros, mesmo considerando o predomínio de processos erosivos, vários tipos de sedimentos foram gerados, especificamente depósitos residuais, eluviais, sedimentos depositados em bacias restritas e principalmente depósitos aluvionares recentes, ao longo das calhas das principais drenagens, que constituem atualmente o registro do Cenozóico na região. 


\section{4 - ASPECTOS GERAIS SOBRE MINERALIZAÇÕES AURÍFERAS EM ZONAS DE CISALHAMENTOS DÚCTEIS}

\section{1 - Mecanismo de Deformação}

A deformação em um dado maciço pode ser homogênea, de natureza instantânea (sísmica), quando é preservado o paralelismo das estruturas pré deformacionais, ou heterogênea, quando não ocorre preservação do paralelismo e a deformação se dá através de incrementos infinitesimais (Ramsay, 1980), caracterizando uma deformação progressiva, com o estado final denominado de deformação finita.

Dois mecanismos básicos caracterizam a deformação, definidos em função dos eixos X, Y e Z do elipsóide de deformação (Strain), ou seja:

- cisalhamento puro, de natureza coaxial, não rotacional, onde predomina achatamento; $\mathrm{e}$

- cisalhamento simples, não coaxial, apresentando rotação gradual dos eixos deformacionais $X$ e $Z$ em torno de $Y$, com $O$ incremento da taxa deformacional.

A evolução da deformação com a profundidade está diretamente relacionada ao comportamento mecânico dos materiais rochosos, ao serem submetidos aos esforços tectônicos. Sob determinadas condições de pressão e temperatura do nível crustal superior, as rochas possuem comportamento elástico, predominando deslocamentos cataclásticos. Com o aumento da profundidade, determinadas litologias começam a adquirir comportamento plástico (fluxo milonítico) entrando no campo do cisalhamento dúctil, caracterizado por deformação progressiva e penetrativa, sob mecanismo de cisalhamento simples. Sibson (1977) idealizou esquematicamente essa transição, em uma seção característica de uma zona de cisalhamento (Figura 7), posicionando o limite dúctilrúptil, que coincidiria aproximadamente com as condições que limitam a fácies xisto verde.

O elipsóide de tensões stress é caracterizado por três eixos denominados : $\sigma 1$ (compressão), $\sigma 2$ (intermediário) e $\sigma 3$ (tração), considerando-se normalmente $\sigma 1>\sigma 2>\sigma 3$.

Nos experimentos conduzidos em laboratório, conforme Ramsay e Huber (1983) e Hodgson (1989), expressados através de curvas tensão $(\sigma)$ versus deformação $(\varepsilon)$, é possivel verificar a existência de três tipos básicos de comportamento de materiais: rúptil, rúptil-dúctil e dúctil. Hodgson (1989) explicita que sob condições relativamente baixas de pressão confinantes e temperatura, no caso de pressão de fluídos e/ou taxa de deformação altas, as rochas normalmente rompem, desenvolvendo fraturas extensionais paralelas a $\sigma 1$. 


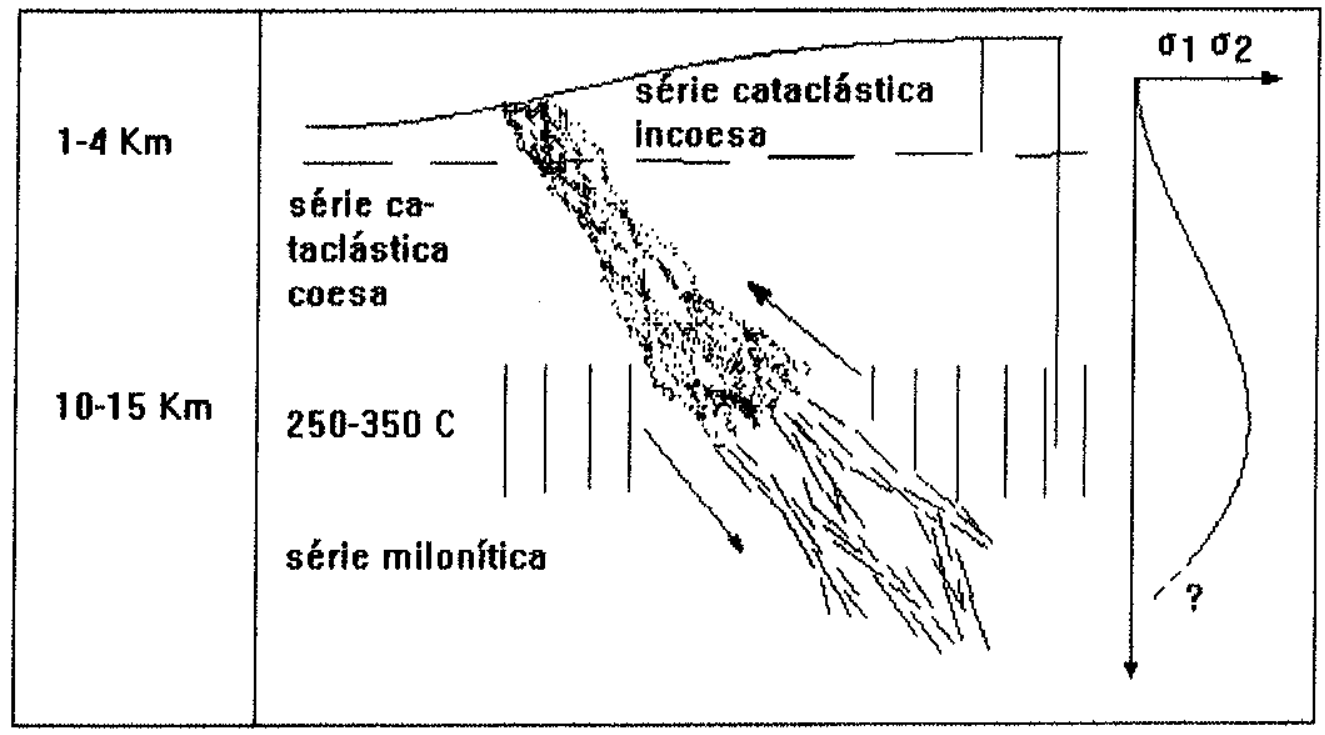

Figura 7. Modelo esquemático para uma zona de cisalhamento. Sibson (1977).

Com o incremento da pressão e/ou de temperatura, ou alternativamente, com o decréscimo da pressão de fluídos e/ou da taxa de deformação, as fraturas extensionais cedem lugar às fraturas de cisalhamento, tendo início o fluxo dúctil.

Em determinados tipos de materiais, com o aparecimento da primeira deformação plástica, após o limite de elasticidade, persistindo o incremento da taxa deformacional tem início o comportamento denominado strain softening. O fenômeno strain softening pode ser compreendido como um estado de relaxamento alcançado pelos materiais rochosos, a partir de um dado nível de tensão, em que adquirem um comportamento plástico-viscoso. Esta propriedade é extremamente importante para se entender a configuração e a mecânica das zonas de cisalhamento dúcteis, esclarecendo o por que da tendência destas zonas em concentrarem cada vez mais a deformação, impedindo de tal maneira a propagação da deformação, que geralmente ocorrem circundadas por rochas indeformadas (pods), ou deformadas homogeneamente (Ramsay \& Graham, 1970).

A foliação milonítica é a estrutura interna que caracteriza as zonas de cisalhamentos dúcteis. Segundo Ramsay \& Huber (1983), três mecanismos são fundamentais na deformação de minerais:

- Fluxo Plástico: desenvolvido a partir da rotação intracristalina de minerais, orientados segundo o plano $X Y$ do elipsóide;

- Deslizamentos Intergranulares: o deslocamento se dá ao longo da superficie de contato entre os grãos; e

- Dissolução e Recristalizacão por Pressão: afeta principalmente determinados minerais como o quartzo e calcita, que sob pressões elevadas sofrem 
processos de transferência de massa (dissolução) das faces sujeitas a compressão ( $\sigma 1$ ), para as zonas de menor tensão ( $\sigma 3)$.

\section{2- Estruturas}

Hodgson (1989), realça que os processos inerentes à deformação heterogênea cisalhante nos maciços rochosos são fundamentais para o entendimento dos depósitos tipo veios, uma vez que muitas das estruturas geradas em contextos sin-deformacionais são significativas para a disposição geométrica dos sistemas de veios.

Os trabalhos experimentais de Riedel (1929) e Tshalenko (1968) (in: Roberts, 1987), direcionados ao estabelecimento do padrão e da sequência de fraturas em uma zona de cisalhamento, inicialmente sob regime rúptil, conduziram à identificação de pelo menos cinco tipos básicos de fraturas, atualmente reconhecidas e utilizadas como referência, tanto no regime dúctil-rúptil, como dúctil.

A Figura 8 representa esquematicamente a orientação das principais fraturas; extensional ( $T$ ) e de cisalhamento $\left(r, r^{\prime}, p, p^{\prime}\right.$ e d ) geradas no interior de um binário de cisalhamento transcorrente. A interpretação dessas fraturas em sistemas de cisalhamentos conhecidos pode auxiliar na previsão da atitude e mesmo locação de corpos de minério.

Diversos critérios são citados na literatura para discernir as fraturas extensionais das de cisalhamentos, a saber:

Fraturas Extensionais

- Geralmente não exibem cataclase ou milonitização;

- Frequentemente estão preenchidas;

- Por vezes estão associadas a enxames de diques de diabásio;

- No caso de fraturas de alívio, são geralmente sub-horizontais;

- Disposição paralela aos planosYZ do elipsóide de deformação; e

- Veios são geralmente maciços, espessos, com evidências de formação em um único evento.

Fraturas de Cisalhamento

- Frequentemente balizadas por zonas de cataclase ou milonitização;

- Exibem grande diversidade de Slickensides;

- Frequentemente apresentam sigmóides tectônicos;

- Ocorrem geralmente em pares conjugados com ângulos de $66^{\circ}$, e $\sigma 1$ na bissetriz;

- Por vezes podem estar preenchidas, principalmente nas zonas tracionais subordinadas; e

- Estão presentes veios acamadados ou bandados, refletindo fases múltiplas de abertura e preenchimento. 


\section{SISTEMAS DE FRATUKAS PREVISTAS}

EM UM BINA'RIO DE CI SALHAMENTO
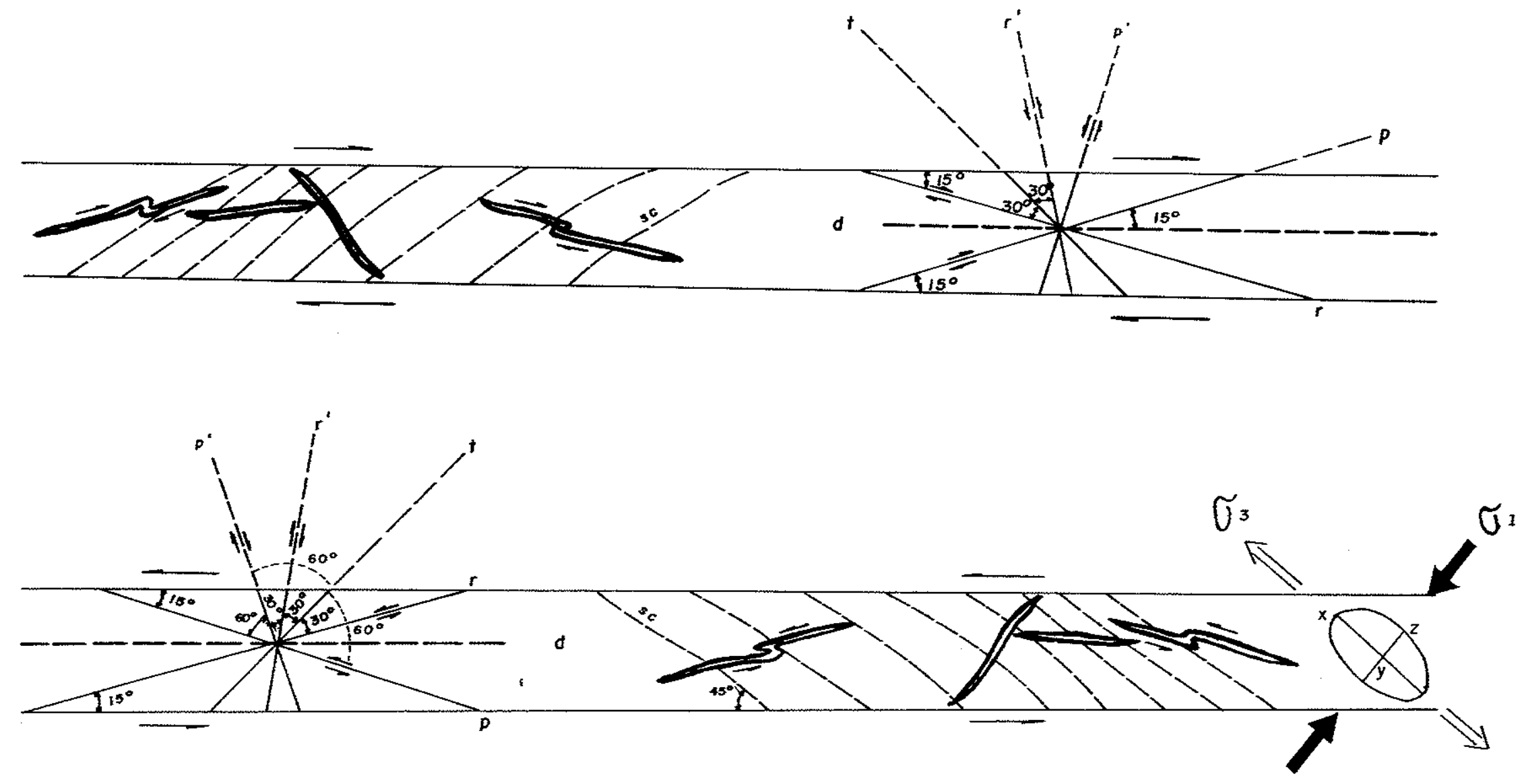

Fonte: boseado com modificagöes en Robents, R.G.(1987) Hodgson, C.j(1989) Baxten, J. L. ef. ol. (1991)
Fratura extensional: t-poralelo ao plano yz, bissetrizentre ofraturos rert土 1 o superficio slsel Fraturos de cisalhamento: $r$-de boixo angulo ( $15^{\circ} \mathrm{e} / \mathrm{z}$ ) denoturezo rúptil precoce.

p-de boixo angulo $\left( \pm 15^{\circ} \mathrm{e} / 2 \mathrm{C}\right.$ ) de natureza dúctil tardia

$r^{\prime}$ de olta onguto $\left( \pm 75^{\circ} \mathrm{e} / z e\right.$ ) reversos ou antetica.

- ocorrem no centro, tía zc.

$P^{\prime}$-antetica, faz angulo de $\pm 75^{\circ} \mathrm{comzc}$ conjugado o $P 75^{\circ}$

SuDEricie:

c - bonda de cioplinomento. 
As heterogeneidades pretéritas existentes nos maciços, tais como acamamento, foliação e fraturamento exercem importante controle na instalação das zonas de cisalhamento, bem como na distribuição das estruturas subordinadas, inclusive afetando as relações angulares dos sistemas de fraturas previstos nos modelos experimentais.

Hodgson (1989) argumenta que, no caso das zonas de cisalhamentos conjugadas, muitas vezes se torna dificil distinguir os diferentes tipos de fraturas de cisalhamento geradas a partir de um campo deformacional eminentemente rotacional. A chave para a diferenciação, muitas vezes, está no fato que as fraturas $r$, c e p têm o mesmo sentido de deslocamento que a zona onde estão contidas.

Roberts (1987) pondera que em algumas zonas de cisalhamento os veios podem não se formar, com o ouro ocorrendo na forma disseminada em determinados horizontes miloníticos. Segundo o autor, corpos de minério desse tipo sugerem que o fraturamento e redução dos grãos associados com a milonitização, promove o incremento na permeabilidade das rochas, evidenciando a simultaneidade dos processos deformacionais com a formação de veios e/ou ore shoots.

\section{3 - Produtos Deformacionais}

As rochas da série milonítica são os produtos típicos da recristalização dinâmica associada ao fluxo plástico. São rochas bandadas, coesivas e de granulometria geralmente muito fina. Frequentemente os milonitos contém cristais maiores residuais, (porfiroclastos), que representam remanescentes da rocha primária, imersos na matriz recristalizada. A proporção e o tamanho dos fragmentos remanescentes e a taxa de deformação, caracterizada pela neo formação de minerais, com desenvolvimento ou não de foliação, são os pontos básicos para a classificação proposta por Sibson (1977) para as rochas cataclásticas, (Figura 9).

\section{4 - Mecanismo de Movimentação de Fluidos e Formação de Veios}

Sibson et al. (1975, in Ramsay and Huber, 1987), a partir da verificação da periodicidade dos grandes sismos, registrados através de significativos deslocamentos no sistema de falhas San Andreas, e de outras observações evidenciando o estabelecimento de expressivo fluxo aquoso, simultâneo ou logo após as atividades sísmicas, propuseram o modelo denominado "mecanismo de dilatação fluida e difusão". Segundo este modelo, a variação na pressão hidráulica da fase fluida nos poros das rochas situadas nas adjacências dos planos de falhas, seria o grande motor, facultando o desencadeamento dos episódios sísmicos, ou pulsos sísmicos.

Ramsay (1980 e 1987), sugere que o mecanismo proposto para os pulsos sísmicos, pode ser utilizado para entender a formação das fraturas 
CLASSIFICACÃO DE ROCHAS CATACLÁSTICAS

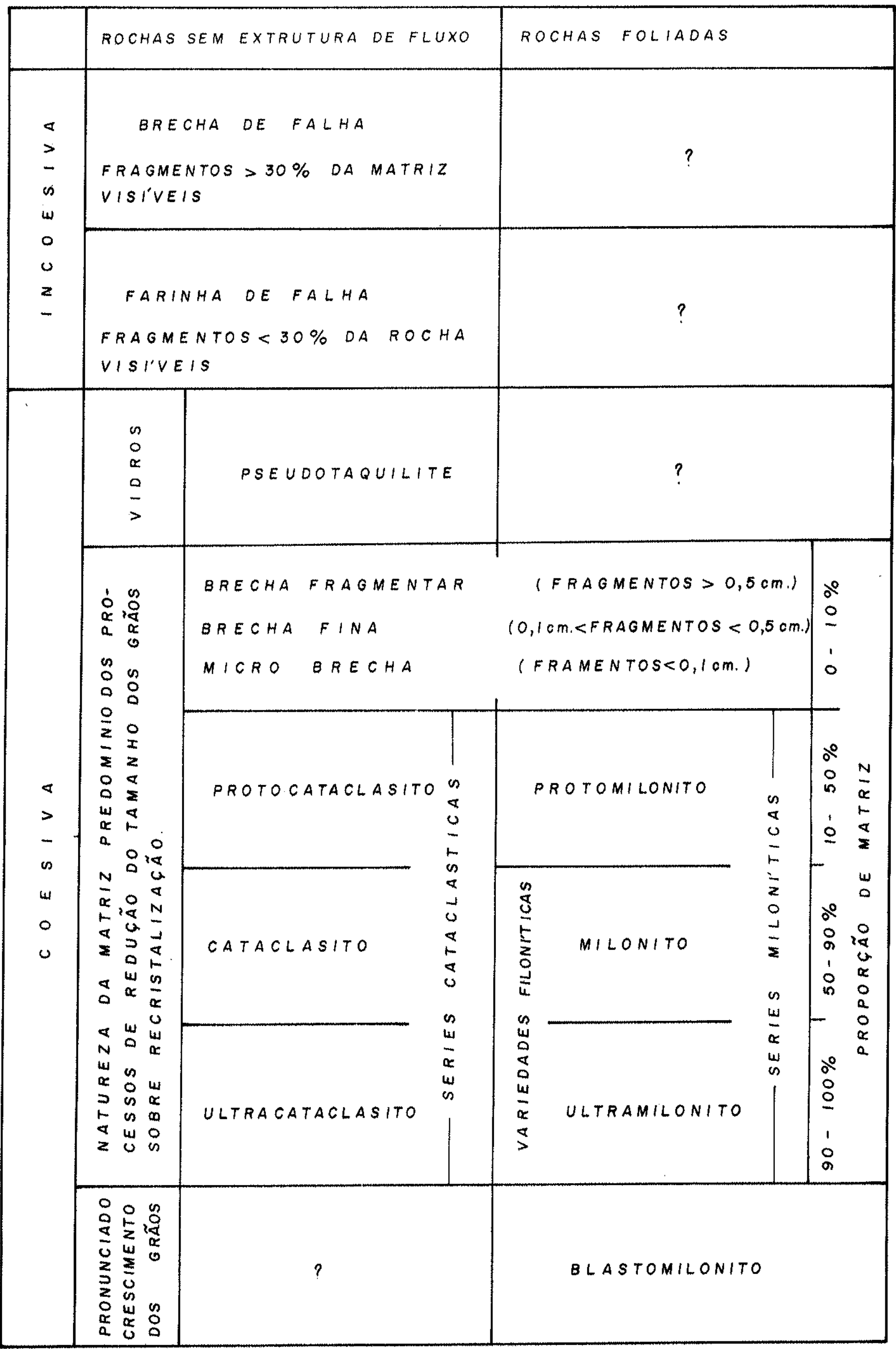


hidráulicas, importantes para o estabelecimento do mecanismo de crack seal, Ramsay (1980).

Ramsay e Huber (1983), utilizam para ilustrar o processo de crack seal as estruturas de crescimento verificadas em veios fibrosos, com as fibras minerais orientadas paralelas a direção de estiramento principal ( $\mathrm{X}$ ), preenchendo tanto estruturas de cisalhamento, como extensionais.

Hodgson (1989) acredita que, embora possa ocorrer de forma temporaria e localmente de a pressão de fluído ser superior à pressão litostática durante a formação de veios mineralizados associados ao mecanismo de hidrofraturamento, isso não implica necessariamente que as zonas distensionais existentes nas fraturas de cisalhamento tenham sido geradas e mantidas por altas pressões de fluídos, sem considerar o papel ativo desempenhado pelas forças tectônicas.

\section{5 - Controles Regionais}

A maioria dos trabalhos e publicações disponíveis sobre mineralizações auríferas publicados nos últimos anos enfocam depósitos alojados em dois tipos de terrenos, diretamente relacionados a dois períodos com grande concentração de depósitos na crosta, ou seja: o Arqueano, com os terrenos granitogreenstone (Woodwal, 1988), e o periodo posterior a $100 \mathrm{Ma}$, representado principalmente pelos depósitos de cordilheira do oeste americano (Berger, 1988) e da costa oeste do Pacífico, associados aos sistemas geotermais dos arcos de ilha (Sillitoe, 1988).

A importância dos terrenos granito-greenstone na produção de ouro é notória, e para o melhor entendimento do contexto metalogenético no âmbito da Província Amazônia Central alguns aspectos inerentes às províncias arqueanas mais produtivas do mundo merecem ser destacados.

Os trabalhos mais recentes sobre mineralizações auriferas vêm enfatizando os controles químico e estrutural como os mais efetivos na geração e no posicionamento dos depósitos auríferos.

Groves et al. (1987) e Groves (1988) consideram que, a existência nos greenstone belts de zonas estreitas submetidas a forte strain, caso das zonas de cisalhamento dúcteis, em meio a extensas faixas onde predomina baixo strain, determinam condições ideais para a canalização dos fluidos sin-metamórficos. Desta forma, os sistemas de falhamentos e/ou zonas de cisalhamento que penetram profundamente até a base dos greenstone belts $(10$ a $15 \mathrm{Km})$ seriam imprescindíveis para a coleta e circulação de fluídos, enquanto que para a deposição do ouro é fundamental a existência de estruturas distensionais subordinadas às megaestruturas, e existência de rochas hospedeiras com alta razão Fe/Mg. Estes fatores, segundo os autores, justificam o notável enriquecimento do greenstone belt Norseman-Wiluna, oeste da Austrália. 
Groves et al. (1987) a partir do modelo metamórfico, procuram explicar não apenas as feições locais e regionais das mineralizações, mas o porquê da distribuição espacial e temporal heterogênea dos depósitos, entre e dentro dos greenstone belts. O autor acredita que, a partir de modelos apropriados é possível determinar os principais controles e fatores determinantes na formação das mineralizações auríferas.

Groves et al. (1987) tecem inúmeros argumentos favoráveis ao modelo metamórfico, apresentando-o como capaz de explicar a distribuição e o comportamento dos depósitos de ouro nos greenstone belts, baseados na presença de quatro importantes controles deposicionais:

1 - Altas temperaturas, baixas pressões e geralmente baixo strain dos regimes metamórficos presentes nos greenstone belts;

2 - Sistemas de falhas e zona de cisalhamento dúcteis de escala crustal;

3 - Rochas inalteradas ricas em ferro (basaltos, BIFs), posicionadas em níveis estratigráficos e metamórficos apropriados; e

4 - Abundância de rochas komatíticas e sedimentos piritosos ricos em ouro.

A constatação, nos greenstone belts do Zimbabwe, de significativo aumento dos depósitos epigenéticos de ouro em direção aos terrenos mais jovens dos grupos Bulawayan $(2,9$ - 2,7 Ga) e Shamvaian, foi atribuída por Anhausser (1976) e Viljoen (1984), às características físico-químicas dos litotipos pertencentes a estes grupos, enquanto Foster e Wilson (1984), associam o fato a processos de remobilização por fluidos ígneos, associados às intrusões dos tonalitos Sesombi, com alta fugacidade de oxigênio e consequente elevada razão $\mathrm{SO}_{2} / \mathrm{H}_{2} \mathrm{~S}$.

Colvine (1988) associa as principais mineralizações da Província Superior, Canadá, a um cinturão de cisalhamento que se estende desde a região de Timmins-Kirkland Lake em Ontário, até o Val d' Or, em Quebec. Este cinturão de cisalhamento, de direção aproximada E-W, com cerca de $200 \mathrm{~km}$ de extensão, por 3 a $4 \mathrm{~km}$ de largura separa os dois principais domínios do greenstone belts do Abitibi: o domínio norte, predominantemente vulcânico e mais antigo, e o sul constituído principalmente por sedimentos. Observam-se neste cinturão centenas de zonas de cisalhamento dúcteis, anastomosadas, separadas por pods de rochas menos deformadas. As mineralizações auríferas são frequentemente stratabound, limitadas a determinadas sequências do greenstone ou a tectonitos, conforme Poulsen e Robert (1988).

Existe um consenso entre vários autores, sintetizado no trabalho de Roberts (1989), que os filōes auriferos encaixados nos terrenos Arqueanos e os respectivos halos hidrotermais estão associados a evolução da deformação progressiva ao longo de estruturas de cisalhamento regionais, com os períodos mineralizantes principais geralmente associados às fases finais de desenvolvimento estrutural, com granitização e intrusões. 
Segundo Card (1988, in: Richard et al., 1991), o fator nível crustal pode ser importante controle genético na presente distribuição dos depósitos de ouro na Provincia Superior. O autor identifica duas situą̧ões frequentes nesses terrenos granito-greenstone:

- Em níveis de erosão rasos, a razão greenstone/granito é alta, e portanto se observa maior proporção de rochas supracrustais, com expressiva quantidade de corpos subvulcânicos, com depósitos de ouro de porte, caso das mineralizações associadas aos granitos subvulcânicos tipo TTG no Abitibi;

- Em níveis de erosão mais profundos onde a razão greenstone/granito é baixa predominam rochas gnáissicas, e as mineralizações são menos significativas.

Com relação ao metamorfismo, existe o consenso de que os depósitos tendem a se formarem na zona de transição entre as fácies anfibolito e xisto-verde, em temperaturas compativeis com aquelas encontradas experimentalmente por Seward (1973), in Viljoen (1984), em que o ouro, eventualmente transportado por soluções cloradas ou tio-complexos, apresenta pronunciado decréscimo na taxa de solubilidade.

Fyfe e Henley (1973) consideram como premissa básica que a maioria dos depósitos hidrotermais do tipo veio de quartzo aurífero ocorrem em regiões de fácies xisto verde, correspondendo a temperaturas entre 300 a $400^{\circ} \mathrm{C}$ e pressões de 2 a $8 \mathrm{~Kb}$.

Segundo os autores, condições favoráveis à circulação de fluidos começam a existir em regiōes de alto gradiente geotérmico, a profundidades da ordem de $5 \mathrm{~km}$, quando pressão fluído $\geq$ pressão total $(\sim 300 \mathrm{bar} / \mathrm{km})$. Nestas condições, com pressão de fluidos maior que a litostática, os fluidos começam a gerar micro-fraturamentos hidráulicos, estabelecendo gradientes de pressão que vêm a incrementar o fluxo de soluções em direção às zonas de alívio (cf. Etheridge et al. 1984, in: Boulter et al., 1987).

O gradiente de pressão pode ser incrementado por reações de desidratação, que ocorrem na interfácie metamórfica anfibolito-granulito ou mesmo associado a processos de degaseificação do manto. Ambas as hipóteses são admitidas com frequência pelos autores que aceitam, com variações, o modelo da secreção metamórfica como um provável mecanismo para a origem das soluções mineralizadas, caso dos trabalhos de Fyfe e Henley (1973), Boyle (1979), Phillips (1984), Colvine (1984) e Groves et al. (1984).

Boyle (1987) cita várias outras teorias para explicar a fonte dos fluídos mineralizados, caso das teorias magmática hidrotermal, exalativa e da granitização. O modelo magmático hidrotermal é o único que implica em uma fonte específica para as soluçð̃es mineralizadas e surgiu em função do estreito relacionamento dos depósitos de ouro com intrusões do tipo pórfiros (Emons 1973, in: Boyle, 1987), e evoluiu atualmente para a concepção dos sistemas geotermais ativos, onde a identificação de corpos ígneos tomoumse irrelevante, segundo White (1981, in: Boyle, 1987). 
O alojamento preferencial dos depósitos de ouro em determinados horizontes lito-estratigráficos, caracterizando uma mineralização stratabound, mesmo em jazimentos onde o controle da mineralização é estrutural, evidencia a importância do quimismo das encaixantes, que ao interagirem com as soluções mineralizadas, provocam a precipitação do ouro.

\section{6 - Tipologia dos Depósitos}

O substrato geológico da região de Peixoto de Azevedo apresenta similaridades com os terrenos granito-gnáissicos, tipo TTG, frequentes nas províncias arqueanas do Mundo, porém, expondo níveis mais profundos em função do grau de arrasamento do relevo. Localmente, a pequena proporção relativa de rochas supracrustais e de litotipos mais reativos restringe significativamente o potencial no que se refere a eventuais jazimentos de grande porte, limitando-se em princípio, a depósitos de pequeno $(<1 \mathrm{t})$ a médio $(1 \mathrm{a} 10 \mathrm{t})$ portes, segundo parâmetros de Philips (1985, in: Lacerda, 1990). Os depósitos são principalmente do tipo preenchimento de fraturas, condicionados às mega estruturas de cisalhamento que afetam os Granitóides Arqueanos ou relacionados especialmente às atividades granitogênicas proterozóicas superimpostas, com remobilização do ouro associado a fases de intenso hidrotermalismo.

$\mathrm{Na}$ Plataforma Amazônica, três depósitos apresentam feições similares aos da região de Peixoto de Azevedo: Salamangone - AP, Cumaru - PA e Porto Nacional - GO.

\section{Depósito de Salamangone - AP}

Constitui mineralizações auríferas sob a forma de veios de quartzo, encaixados em gnaisses tonalíticos, com restos de supracrustais e mega-enclaves de anfibolitos, segundo Ferran (1988), representando um greenstone belts em grande parte tonalitizado.

Os veios de quartzo são subverticais, múltiplos, alinhados na direção N45E, com pirita e calcopirita, e extensão máxima da ordem de $100 \mathrm{~m}$. O contato com os gnaisses tonalíticos encaixantes é brusco.

As reservas de ouro primário avaliadas somam 450.000 toneladas de minério, com teor de $16 \mathrm{~g} / \mathrm{t}$, equivalente a 7 toneladas de ouro contido.

Com referência à gênese do minério, o autor citado sugere uma possivel zona de cisalhamento, com evolução anterior à tonalitização, uma vez que não são visíveis produtos cataclásticos. Outra alternativa proposta pelo autor é que os veios na verdade seriam metacherts recristalizados. 


\section{Depósito de Cumaru - PA}

Os depósitos de ouro estão encaixados no Granodiorito Cumaru, descrito por Leonardos et al. (1991), localmente representados por diversos corpos intrusivos no greenstone belts de Gradaus, com idades $\mathrm{Rb} / \mathrm{Sr}$ de $2660 \pm 40 \mathrm{Ma}$ e $2543 \pm 53 \mathrm{Ma}$.

Esses granodioritos são isótropos, com biotita e hornblenda como minerais máficos principais. Os dados petrográficos e petroquímicos, segundo os autores, evidenciam similaridades com os granitos tipo I Cordilheiranos, de curta residência crustal, ou com os tipos $M$, de Pitcher (1983, cf. Leonardos et al., 1991).

A mineralização primária é do tipo stockwork, venulada, com microfraturas e veios de quartzo encaixados em um hidrotermalito com quartzo, sericita, carbonato, epídoto, clorita, albita e leucoxênio, resultante de processos de alteração hidrotermal do tipo cloritização, sericitização e carbonatização, que afetam o granodiorito.

Com relação à gênese do minério, Leonardos et al. (1991), argumentam que as feições observadas, o ambiente tectônico e a alta salinidade dos fluidos evidenciam uma provável origem magmática mesotermal, que permite correlacioná-los aos depósitos tipo Au-Cu-Mo pórfiros (andinos) e aos clássicos depósitos mesotermais de arcos de itha, do oeste Pacífico, descritos por Sillitoe (1989).

\section{Depósitos da Região de Porto Nacional - GO}

São inúmeros filões de quartzo auríferos encaixados em granitos, granodioritos e tonalitos e seus equivalentes gnáissicos, pertencentes ao Complexo Granito-Gnáissico, de idade arqueana, conforme Lacerda (1990).

Os depósitos têm marcante controle estrutural condicionado às zonas de cisalhamentos. Minérios do tipo veio de quartzo e milonítico são os mais frequentes. As paragêneses primárias estão representadas por ouro, pirita, arsenopirita, calcopirita, galena e esfalerita. Os corpos têm extensão decamétrica a hectométrica e espessura decimétrica a métrica.

Os depósitos já avaliados na região são de pequeno a médio portes, com teores de 4.65 a $8.33 \mathrm{~g} / \mathrm{ton}$. 
5.1 - Generalidades

A área objeto desse trabalho, com aproximadamente $1.635 \mathrm{Km}^{2}$, localiza-se nos limites da reserva garimpeira de Peixoto de Azevedo, com 6.575 $\mathrm{Km}^{2}$, Figura 02, e foi selecionada em função da expressiva concentração de depósitos auríferos representativos do contexto metalogenético da região.

$O$ desconhecimento geológico da região pode ser atestado pela inexistência de mapeamentos de detalhe, sendo disponíveis apenas mapas regionais, caso do projeto Manissauá - Missú, publicado em 1975, pelo convênio CPRM/DNPM, e do projeto RADAMBRASIL - Folha Juruena, publicada em 1980, com mapas geológicos nas escalas 1:250.000 e 1.000.000, respectivamente.

Neste trabalho, a apesar das dificuldades já abordadas no sub item 1.4 , tornou-se imprescindivel apresentar um mapa geológico na escala $1: 100.000$ que viesse a suprir, mesmo que de forma preliminar, a carência de informações geológicas para essa importante província aurífera, e que ao mesmo tempo fosse uma base geológica razoável para o entendimento e as considerações relativas aos controles das mineralizações auriferas. Dessa forma, mesmo incorrendo no risco de generalizações e conclusões precipitadas, face à deficiência de dados, procuramos apresentar um mapa geológico com o maior número de unidades individualizáveis possível.

Neste contexto, oito unidades litoestratigráficas foram individualizadas, conforme empilhamento proposto na coluna estratigráfica que acompanha o mapa geológico (Anexo 01).

\section{2 - Complexo Xingu}

O Complexo Xingu foi definido por Silva et. al. (1974) como uma unidade polimetamórfica contituida por gnaisses, xistos, migmatitos, anfibólitos, granodioritos, granitos e metabasitos.

Dentro do embasamento polimetamórfico denominado Complexo Xingu, foi possivel individualizar, a princípio, duas unidades litoestruturais típicas dos terrenos Arqueanos. A primeira unidade, denominada Granitóides Arqueanos, corresponde a corpos de aspecto ígneo, composição tonalítica a quartzo diorítica, notóriamente associados aos gnaisses de composição similar e localmente, com mega enclaves de supracrustais, que certamente constituem as sequências mais antigas deste terreno. A segunda unidade, denominada Zonas de Cisalhamentos Dúcteis, corresponde a mega-estruturas de cisalhamentos sustentadas por rochas quartzo miloniticas, com expressiva representação em mapa e certamente, um dos principais controles determinantes na distribuição e arranjo geométrico das fraturas mineralizadas. 
Neste trabalho, o Complexo Xingu está representado principalmente por gnaisses, rochas meta-básicas e meta-ultabásicas, xistos, filitos, metarenitos e granitóides não diferenciados, bastante recristalizados e deformados. As paragêneses minerais dessas rochas refletem frequentemente a ação de processos retrometamórficos e/ou metamorfismo dinâmico.

Alguns dados petroquímicos destas rochas podem ser observados na Tabela 04, porém sem permitir maiores interpretações face à pontualidade $\mathrm{e}$ variação dos tipos petrográficos analisados. Nota-se que os xistos ultrabásicos (PA - 13 e GR - 07) apresentam alto teor de magnésio, resultando em altos percentuais de hiperstênio na norma, baixo teor de alcális e teores relativamente elevados de elementos menores, como cobre, níquel e cromo. Os dados petroquímicos associados com as observações de campo evidenciam tratar-se de metaultramáficas, frequentes nas sequências supracrustais dos terrenos granitogreenstone.

No diagrama AFM (Figura 10) de Irvine e Baragar (1971), é possível verificar a disposição das rochas pertencentes ao Complexo Xingu.

\section{Granitos e Biotita Granitos}

Estas rochas ocorrem principalmente nas imediaç̃̃es da cidade de Peixoto de Azevedo e nas regiões denominadas Garimpo do Aragão, Novo Mundo e Nhandu, sendo os termos equigranulares bastante similares macroscopicamente aos granitos tipo Juruena.

São rochas de coloração cinza a róseo-amarelado, com granulometria fina a grossa, as texturas observadas variam de granular hipidiomórfica, granoblástica a cataclástica, estrutura isótropa ou com discreto bandamento, evidenciado frequentemente pelo alinhamento de grãos de quartzo ou palhetas de mica e hornblenda.

Ao microscópio estas rochas mostram feições de recristalização dos grãos de quartzo, tipo contatos denteados, extinção ondulante em faixas e intercrescimentos gráficos, inclusive com estiramento dos grãos de quartzo e sericitização dos plagioclásios nas zonas com maior intensidade de deformação cataclástica e circulação de fluídos.

A composição mineralógica observada é essencialmente representada por microclínio (pertítico), ortoclásio, quartzo, plagioclásio, biotita, sericita, epídoto e titanita.

A presença de megacristais de microclínio, como uma nova fase mineralógica, sugere a atuação de processos metassomáticos, nos termos gnaissicos, ou mesmo através de enriquecimento potássico proviniente de fonte magmática, nas proximidades de intrusões e apófises graníticas.

A biotita frequentemente está alterada para clorita, com inclusões de titanita, apatita, zircão, e opacos, enquanto o plagioclásio encontra-se sausuritizado e por vezes alterado para sericita e epidoto, principalmente nas proximidades das megas zonas de cisalhamento dúctil que cortam o embasamento. 
Tabala 04. Anǵliso quimica, Morma (CIFW) moda para tipom

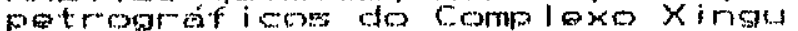

\begin{tabular}{|c|c|c|c|c|c|c|c|c|c|c|c|}
\hline \begin{tabular}{|c|c|}
$\begin{array}{c}0.0 \times 1 \\
\text { DOS }\end{array}$ & $\begin{array}{l}\text { Anos } \\
\text { In }\end{array}$ \\
\end{tabular} & $60=10$ & $\begin{array}{l}P a-88 b \\
?\end{array}$ & $\begin{array}{r}\mathrm{Pa} 88 \mathrm{~d} \\
1\end{array}$ & $\begin{array}{r}\mid r a-88 d \\
\vdots \\
\end{array}$ & $\begin{array}{r}P a-13 \\
2 \\
\end{array}$ & $P_{i 3.134}$ & $P \mathrm{P}+139$ & $\mathrm{~Pa}+145$ & $6 r-07$ & $\mathrm{~Pa} 136$ & Par tos? \\
\hline 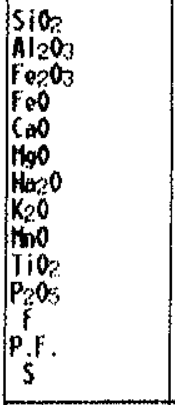 & $\begin{array}{c}71.6 \\
14.8 \\
1.5 \\
0.25 \\
1.05 \\
0.9 \\
0.17 \\
1.7 \\
0.02 \\
0.2 \\
0.05 \\
0.079 \\
2.67 \\
0.011 \\
\end{array}$ & $\begin{array}{l}48.3 \\
12.3 \\
13.4 \\
6.1 \\
6.2 \\
5.2 \\
0.1 \\
1.3 \\
0.21 \\
0.91 \\
0.17\end{array}$ & $\begin{array}{l}46.9 \\
11.9 \\
8.0 \\
6.8 \\
6.8 \\
8.0 \\
0.58 \\
3.4 \\
0.29 \\
1.0 \\
0.13 \\
0.45 \\
5.09 \\
0.54\end{array}$ & $\begin{array}{c}99.7 \\
20.8 \\
6.2 \\
0.67 \\
0.81 \\
3.7 \\
2.4 \\
2.9 \\
0.06 \\
0.73 \\
0.67\end{array}$ & $\begin{array}{c}57.3 \\
9.4 \\
7.9 \\
5.2 \\
0.84 \\
16.4 \\
0.08 \\
0.05 \\
0.13 \\
0.1 \\
0.73\end{array}$ & $\begin{array}{c}48.6 \\
14.2 \\
8.3 \\
5.2 \\
5.9 \\
4.3 \\
4.3 \\
2.4 \\
0.22 \\
1.0 \\
1.7\end{array}$ & $\begin{array}{l}44.4 \\
13.4 \\
4.4 \\
7.3 \\
3.1 \\
1.9 \\
3.4 \\
1.4 \\
0.7 \\
1.3 \\
0.68 \\
0.094 \\
3.83 \\
0.1\end{array}$ & $\begin{array}{l}48.5 \\
17.0 \\
6.6 \\
7.9 \\
40.0 \\
8.4 \\
1.9 \\
0.40 \\
0.24 \\
0.06 \\
0.06 \\
0.074 \\
9.05 \\
0.24\end{array}$ & $\begin{array}{c}54.4 \\
6.6 \\
7.3 \\
7.1 \\
0.14 \\
77.4 \\
0.04 \\
0.61 \\
0.12 \\
0.31 \\
0.20 \\
8.7\end{array}$ & $\begin{array}{l}45.6 \\
11.2 \\
6.6 \\
7.5 \\
9.2 \\
6.8 \\
1.1 \\
1.2 \\
0.15 \\
1.6 \\
0.95 \\
3.4 \\
0.19 \\
\end{array}$ & $\begin{array}{l}63.1 \\
11.3 \\
7.5 \\
1.2 \\
6.3 \\
6.0 \\
0.81 \\
5.1 \\
0.12 \\
0.58 \\
0.53 \\
2.4 \\
0.16\end{array}$ \\
\hline \multicolumn{12}{|l|}{$\begin{array}{l}\text { Elertikfos } \\
(\mathrm{ppw})\end{array}$} \\
\hline $\begin{array}{l}\mathrm{Cl} \\
\mathrm{S} \\
\mathrm{Au} \\
\mathrm{As} \\
\mathrm{Cu} \\
\mathrm{Pb} \\
\mathrm{Zn} \\
\mathrm{l} . \mathrm{a} \\
\mathrm{Hi} \\
\mathrm{Cr} \\
\mathrm{Bo} \\
\mathrm{Bi} \\
\mathrm{Ho} \\
\mathrm{C} \\
\mathrm{Co}\end{array}$ & $\begin{array}{c}2.0 \\
N\end{array}$ & $\begin{array}{c}4.5 \\
N \\
2 \\
4.5 \\
8 \\
71 \\
45 \\
00 \\
20 \\
18 \\
4 \\
14 \\
280 \\
45\end{array}$ & H & 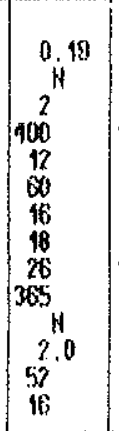 & $\begin{array}{c}0.05 \\
14 \\
1.1 \\
1020 \\
79 \\
88 \\
38 \\
475 \\
1580 \\
30 \\
4 \\
14 \\
108 \\
38\end{array}$ & . $\begin{array}{c}0.77 \\
0.07 \\
4 \\
25 \\
10 \\
146 \\
7.4 \\
9 \\
8 \\
85 \\
5.4 \\
14 \\
7.0 \\
76 \\
24\end{array}$ & $\begin{array}{l}110 \\
N \\
1.1 \\
47 \\
6 \\
67 \\
144 \\
336 \\
220 \\
H \\
1.2 .0 \\
80 \\
339\end{array}$ & $\begin{array}{r}720 \\
N \\
2 \\
87 \\
6 \\
65 \\
60 \\
68 \\
620 \\
N \\
740 \\
84 \\
28\end{array}$ & $\begin{array}{r}1 \\
2 \\
280 \\
8 \\
390 \\
860 \\
1500 \\
900 \\
4 \\
860 \\
88 \\
38\end{array}$ & $\begin{array}{r}4 \\
1 \\
220 \\
6 \\
32 \\
58 \\
86 \\
56 \\
1 \\
1.2,0 \\
84 \\
22\end{array}$ & $\begin{array}{r}14 \\
5 \\
88 \\
6 \\
8 \\
32 \\
38 \\
36 \\
124 \\
4 \\
4 \\
78 \\
5\end{array}$ \\
\hline Norma & $6 r-10$ & $\mathrm{~Pa}-88 \mathrm{~b}$ & $\mathrm{~Pa}=88 \mathrm{i}$ & $\operatorname{Par} 88 \mathrm{~d}$ & $P_{0}=13$ & Pa- 134 & $p v-139$ & $\mathrm{Pi}-143$ & $6 r-0 ?$ & $P a-136$ & $\mathrm{~Pa}-104$ \\
\hline quartao & 50.77 & 22.02 & 6.0 & 22.97 & 30.04 & 4.00 & 7.08 & 8.84 & 46.78 & 6.50 & 71.87 \\
\hline Ortoclas io & 28.57 & 8.13 & 24.48 & 19. 46 & 3.37 & $14.6 ?$ & 7.55 & 7.83 & 5.24 & 7.47 & 30.12 \\
\hline Albita & 1.47 & 3.58 & 4.41 & 23.06 & 0.73 & 37.62 & 23.20 & 9.00 & 0.46 & 9.80 & 7.03 \\
\hline Anortita & 0.00 & 20.55 & 71.81 & 0.22 & 2.88 & 12.78 & 26.38 & 27.87 & 0.00 & 31.86 & 17.45 \\
\hline Cor lindon" & 9.73 & 0.00 & 0.00 & 15.69 & 8.89 & 0.00 & 0.00 & 0.00 & 6.42 & 0.00 & 0.00 \\
\hline Hiparstenio & 2.31 & 13.04 & 21.66 & 9.05 & 51.80 & 9.85 & 5.52 & 70.57 & 64.02 & 20.65 & (3.58 \\
\hline Diopsidio & 0.00 & 1.42 & 3,30 & 0.00 & 0.00 & 4.72 & 88.37 & 88.82 & 0.60 & 7.74 & 12.10 \\
\hline Thanet itin & 0.30 & 18.66 & 42.10 & 0.09 & 4.54 & 13.34 & 2.19 & 9.95 & 6.85 & $0.0 ?$ & 2.82 \\
\hline It tonita & 0.38 & 4.89 & 2.03 & 1.57 & 0.21 & 1.96 & 2.87 & 1,90 & 0.64 & 3.20 & 1.04 \\
\hline Apatita & 0.12 & 0.43 & 0.33 & 1.70 & 0.53 & 4.16 & 1.71 & 0.15 & 0.52 & 2.37 & 1.34 \\
\hline Cromita & 0.00 & 8.04 & 0.00 & 0.01 & 0.37 & 0.00 & 0.00 & 0.00 & 0.00 & 0.00 & 0.00 \\
\hline Hewat ito & 4.12 & 1.31 & 0.00 & 6.38 & 0.00 & 0.00 & 0.00 & 0.00 & 3.26 & 0.00 & 0.62 \\
\hline Hofolina & 0.00 & 0.00 & 0.09 & 0.00 & 0.00 & 0.00 & 0.48 & 0.04 & 0.00 & 0.00 & 0.00 \\
\hline Halito & 0.00 & 0.00 & 0.02 & 0.00 & 0.00 & 0.00 & 0.02 & 0.04 & 0.00 & 0.00 & 0.00 \\
\hline
\end{tabular}




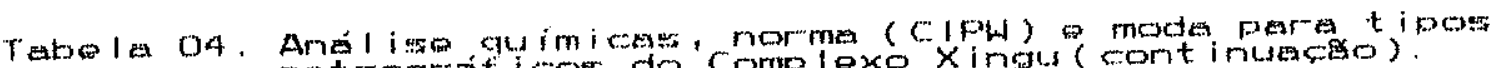

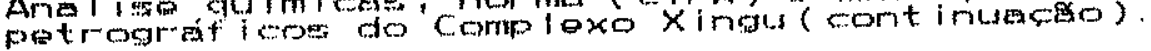

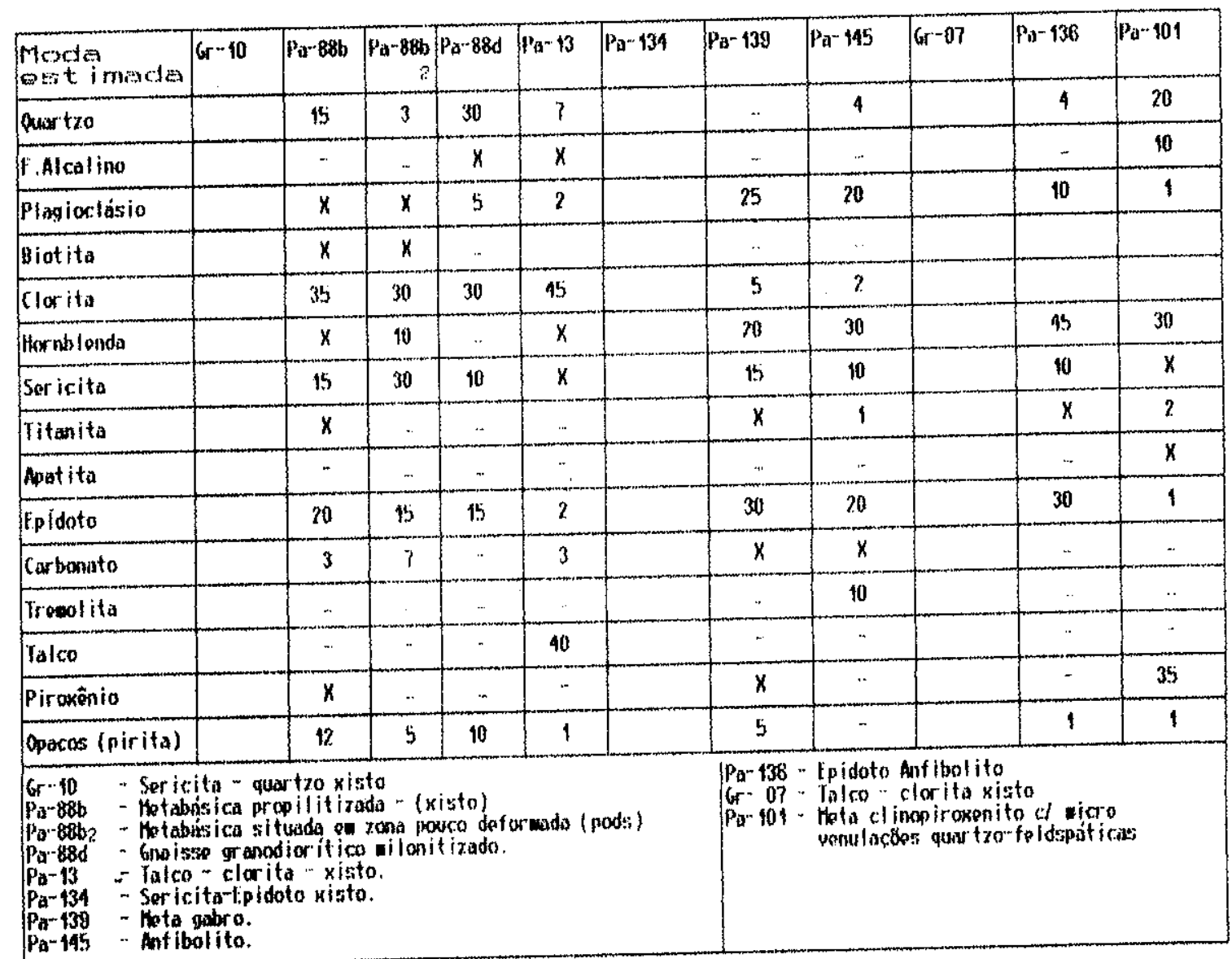

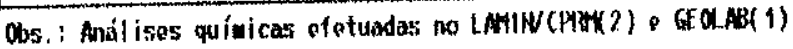

1. wence que o valor registradu.

X. mineral cre wodiz ( $y$.

H. nío detectado 


\section{Gnaisses}

Raros são os afloramentos naturais desses litótipos na área, caso dos pontos PA-181, PA-154, GR-35 e GR-36. Os gnaisses são observados principalmente nas cavas e adjacências dos filōes do Paraiba (PA - 95), Mineiro (PA - 140/160), Melado (PA - 127), Gaspar (PA - 183), Serrinha (PA - 191), Naiuran (GR - 05), Olerindo (GR - 14), Teixeira (GR-30), etc. Estas rochas são frequentemente leucocráticas, de coloração cinza-claro, granulometria fina a média, apresentando bandamento mineralógico, com alternância de leitos milimétricos a decimétricos de anfibólio, biotita e clorita com leitos quartzofeldspáticos.

Os níveis máficos são de composição diorítica a anfibolítica, coloração cinza escura, granulometria fina a média, com plagioclásio dos tipos oligoclásio e andesina (45 a $50 \%$ ), hornblenda (20 a 30\%), biotita (15 a $20 \%$ ) e quartzo $(0$ a $10 \%)$. Os minerais acessórios são titanita e apatita e como minerais de alteração ou secundários, observa-se clorita, epídoto, carbonato, sericita e opacos.

Os niveis quartzo-feldspáticos são de composição granodiorítica a tonalítica, leuco a mesocráticos, coloração cinza-escuro, granulometria média a grossa, com textura granoblástica a granolepidoblástica, com bandas centimétricas constituídas predominantemente por plagioclásio $(45 \%)$ e quartzo $(35 \%)$, alternadas com bandas milimétricas ricas em biotita (15\%). Como minerais acessórios ocorrem hornblenda, clorita, epídoto, apatita, zircão e sericita (Foto 1).

O feldspato potássico (microclínio), está restrito às porções mais leucocráticas, ocorrendo como cristais anedrais, com tamanho da ordem de $1 \mathrm{~cm}$, com inclusões de plagioclásio, clorita e sericita. Localmente, observa-se bolsões ricos em biotita (biotititos), nas proximidades dos apófises de leucogranitos pegmatíticos, que afetam os gnaisses tonalíticos. Verifica-se ainda a cloritização da biotita e sericitização do plagioclásio, provavelmente devido às alterações hidrotermais pervasivas associadas ao desenvolvimento de zonas de cisalhamentos dúcteis (ZCD), que cortam estes gnaisses. Niveis anfibolíticos sub-concordantes com a foliação metamórfica, enclaves alongados e diques de rochas metabásicas são frequentes nos gnaisses.

\section{Xistos}

Os afloramentos observados são pontuais, representados por quartzo-sericita xisto (PA - 137, GR - 04, GR - 10) e talco-clorita xisto (GR - 07 e PA - 13). Muito provavelmente, devem constituir relictos ou mega-enclaves de sequências vulcano-sedimentares, similares a inúmeras outras descritas no âmbito da Província Amazônia Central, região Sul do Pará, caso dos trabalhos de Huhn et al. (1988) e Souza et al. (1988).

Os xistos encontram-se extremamente deformados, com foliação proeminente e sinuosa, evidenciada por minerais micáceos, além de dobras intrafoliais, com charneiras apertadas e desenvolvimento de foliação de crenulação 

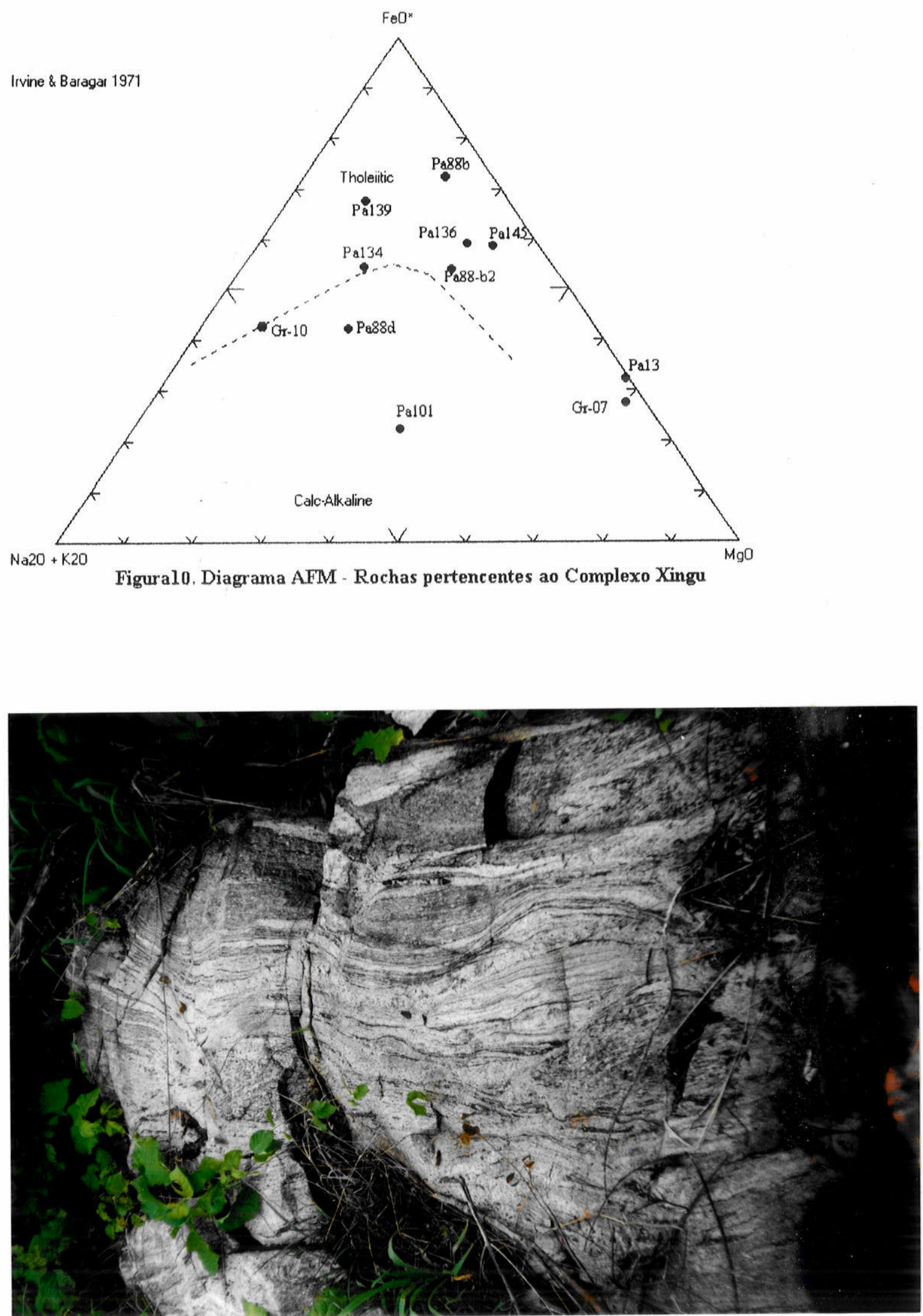

Foto 1: Amostra PA-181. Gnaísses tonalíticos com relictos e enclaves de metabásicas ovaladas, finamente bandado, com alternância de leitos máficos (anfibolitos) e leitos quartzo-feldspáticos (tonalitos). 
e Kink-bands. Nas raras exposições destas rochas nota-se que as mesmas estão afetadas por bandas de cisalhamentos, com transformações mineralógicas intensas e geração de foliações miloníticas superimpostas de natureza sigmoidal. As paragêneses metamórficas enquadram-se no limite das zonas da clorita e biotita, do facies xisto verde.

Nos talco-clorita xisto (PA-13) são marcantes os processos resultantes da deformação cisalhante superimposta. São rochas da coloração cinzaesverdeado, brilho sedoso, com transposição da foliação metamórfica por uma foliação milonítica "sm" (E-W/SV), e desenvolvimento de meso-dobras assimétricas, kinks e veios de quartzo sigmoidais. Em lâmina petrográfica, observase que a rocha apresenta-se deformada, com foliação milonítica bem desenvolvida, evidenciada pela alternância de leitos enriquecidos em clorita e talco. O quartzo apresenta-se recristalizado em sub grãos, na forma de segregações ou micro venulações.

Os minerais micáceos são em grande parte oriundos de alterações de minerais pré-existentes. Nota-se a cloritização da biotita e de opacos, estes com contornos arredondados; grãos reliquiares de feldspato ocorrem como agregados saussuritizados (Microfoto 1).

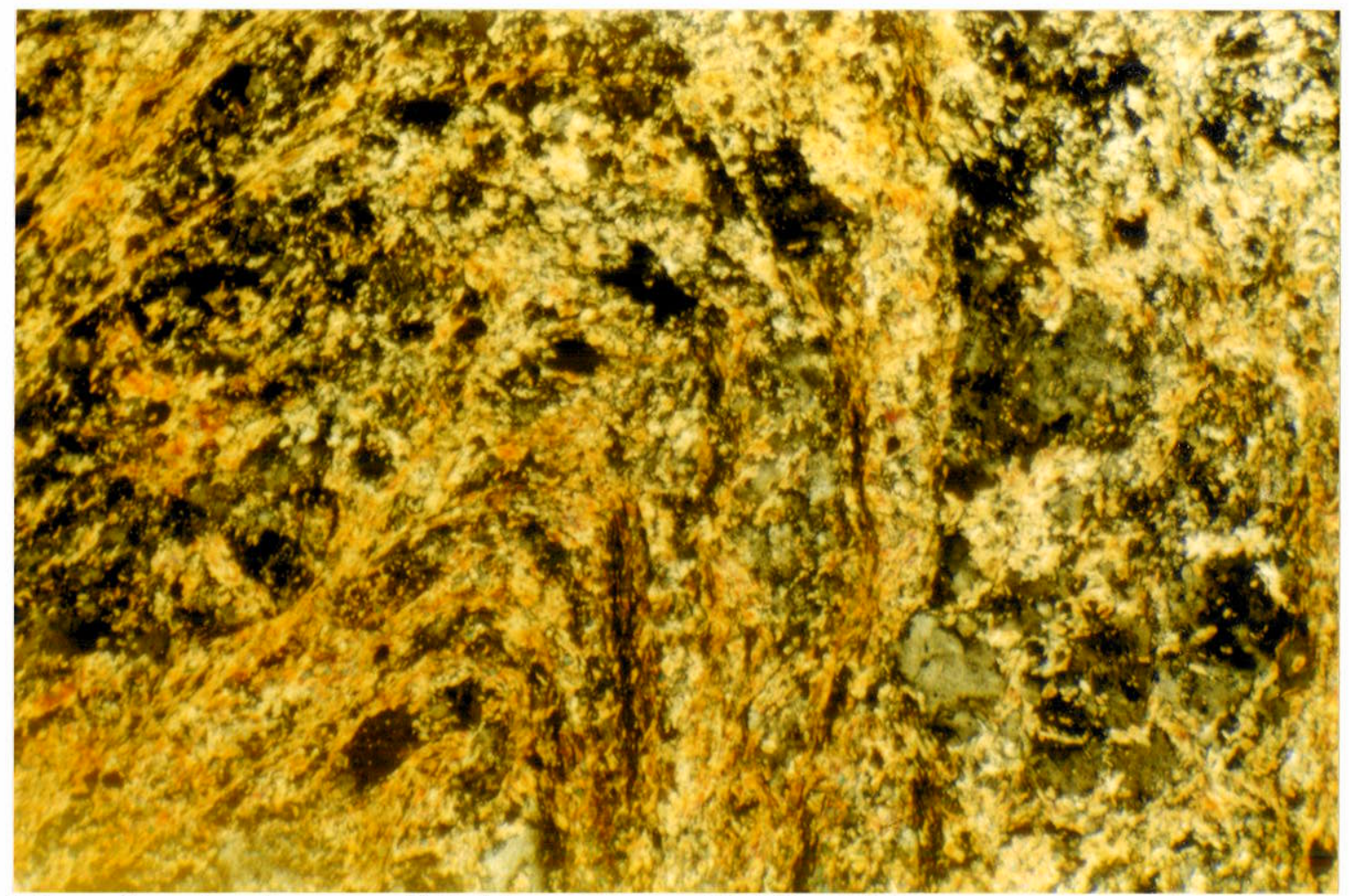

Microfoto 1: Amostra PA-13, aumento 78,75x, NX.

Talco-clorita xisto milonítico. Micro dobra apresentando alternância de leitos de talco e clorita, com segregações de quartzo recristalizado. 
Como acessórios, ocorrem em forma de grãos disseminados, carbonato, opacos (pirita) e óxidos de ferro, estes ainda preenchendo fraturas sub paralelas a foliação milonítica.

As rochas do tipo talco-clorita xisto, aflorantes no lugarejo denominado Santo Antônio (GR - 07), ocorrem em uma faixa alongada segundo a direção W-NW, com tonalidades avermelhadas, na superfície, e em profundidades da ordem de 25 metros, apresentando-se como uma rocha untuosa, de coloração creme esverdeado. Esta rocha é encaixante de um expressivo corpo filoneano, denominado filão Domingos/Sebastião, gerado em um contexto de zonas de cisalhamentos dúcteis múltiplas, sinuosas, de espessuras decimétricas, com direção geral N60W (Foto 2). Em lâmina petrográfica, verifica-se a alternância de leitos ricos em clorita com lamelas de geminação arqueadas e talco, com intensa percolação de óxido de ferro ao longo dos planos de foliações. Como acessórios, ocorrem epídoto e opacos (Microfoto 02).

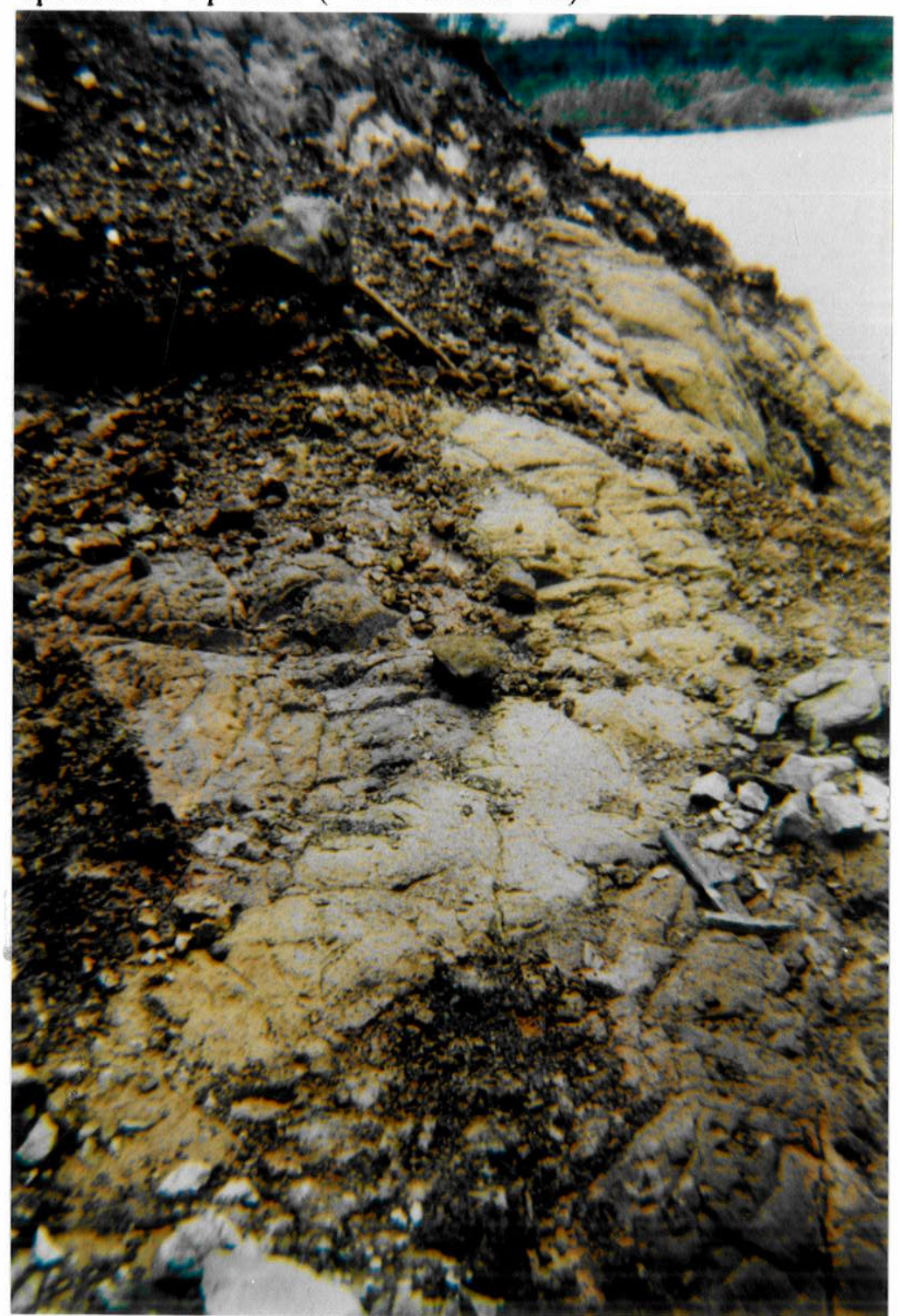

Foto 2: Amostra GR-07. Talco clorita xisto afetados por bandas de cisalhamentos centimétricas anastomosadas, de direção geral N60W. Diques de metabásicas propilitizadas sub paralelas a cava do filão do Domingos. 


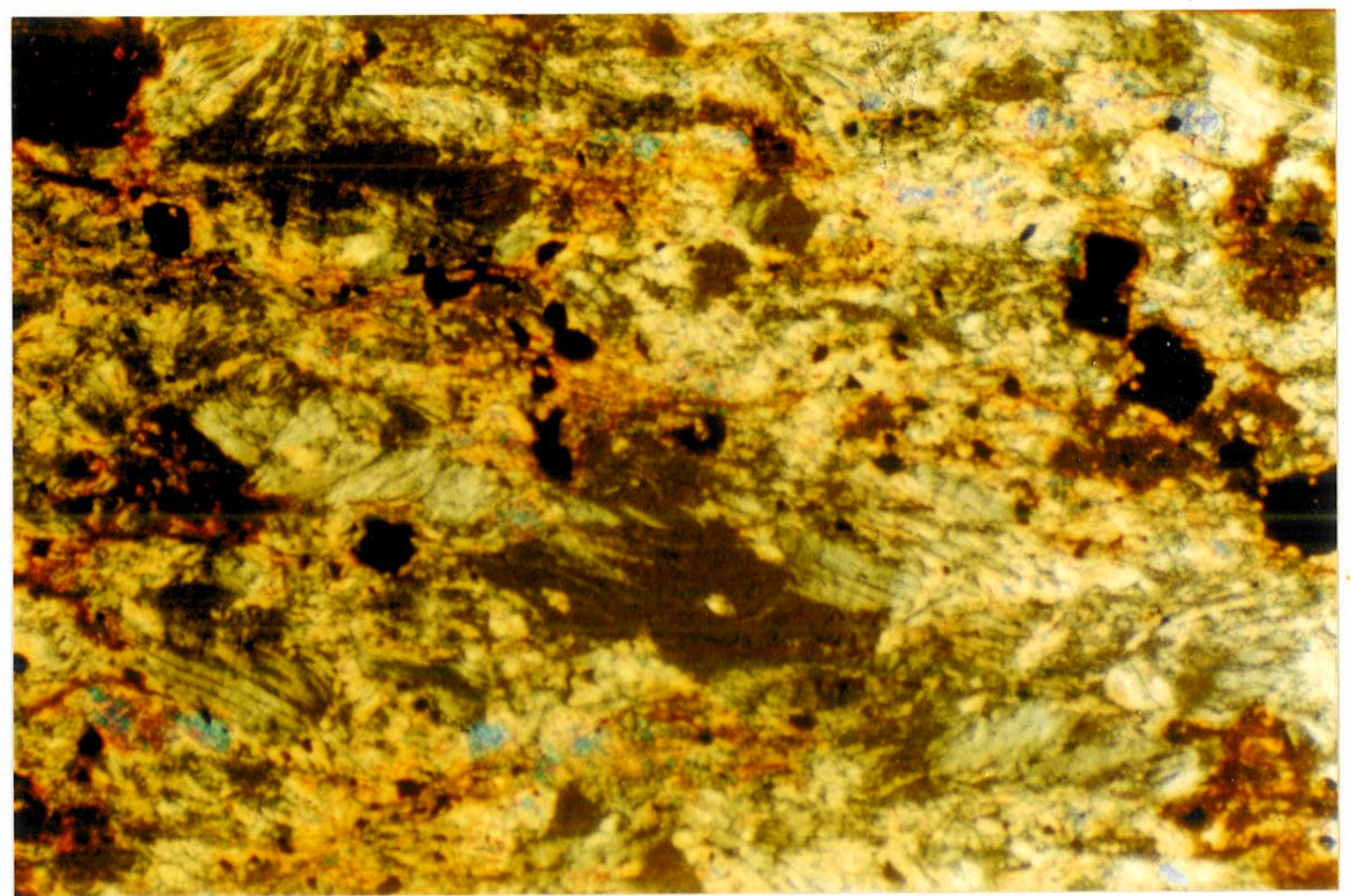

Microfoto 2: Amostra GR-07, aumento 78.75x, NP. Talco-clorita xisto.

\section{Anfibolitos}

Os anfibolitos são rochas com forte anisotropia, de coloração cinza escuro a esverdeado, equigranulares, de granulometria fina a média, com bandamento milimétrico, e textura granonematoblástica. Ocorrem como lentes ou bandas subordinadas aos gnaisses (PA - 145/172, GR - 05) ou a xistos (PA - 136).

Os anfibolitos aflorantes na cava do filão do Paraíba (PA - 145) têm espessuras da ordem de $20 \mathrm{~cm}$ a $30 \mathrm{~m}$, e estão dispostos como lentes orientadas segundo o alinhamento estrutural regional (N-NW). São constituídos por hornblenda (30\%), com inclusões de quartzo e opacos; plagioclásio sericitizado $(20 \%)$, e ainda epídoto $(20 \%)$ e tremolita $(10 \%)$, como produtos de alteração hidrotermal da hornblenda, principalmente ao longo de vênulas, dispostas subparalelamente à foliação metamórfica. A pirita ocorre disseminada e ao longo dos planos de fraturamento.

O anfibolito coletado no ponto PA - 136 ocorre como bandas da ordem de metros, disposto em uma sequência de sericita-quartzo xisto (PA - 137), com evidências de cataclase. Os anfibolitos apresentam-se alterados, sendo frequentemente constituídos de hornblenda verde (45\%), localmente cloritizada, com inclusões de quartzo; plagioclásio (10\%), transformado em uma massa de epídoto $(30 \%)$ e sericita $(10 \%)$, evidenciando retrometamorfismo do fáceis anfibolito caracterizado pela paragênese plagioclásio + hornblenda + titanita, para a fáceis xisto verde, com clorita + epidoto + sericita + leucoxênio. 


\section{Metabásicas e Meta-ultrabásicas}

Essas rochas ocorrem em raras exposições pontuais, e sua presença evidencia a provável existência de restos de rochas supra-crustais ou mesmo antigos complexos básico - ultrabásicos na região. Alguns veios apresentam estreito relacionamento com estas rochas, caso dos filões do Paraiba, Naiuran, Mineiro, Sede, Armando, Levi, e outros.

No ponto PA - 139, aflora um micro-gabro maciço, de coloração cinza-escuro e textura subofitica, constituído por plagioclásio $(20 \%)$, alterando-se para sericita $(15 \%)$; com hornblenda $(20 \%)$, epídoto $(30 \%)$ e clorita (5\%) provavelmente oriundos da alteração progressiva de piroxênios, que ocorrem com relictos. A amostra PA - 138 reflete sobretudo os processos metamórficos a que foi submetido o microgabro (PA - 139), sendo transformado em um xisto, esverdeado, com sericita $(50 \%)$ e clorita $(47 \%)$.

A amostra GR - 06, corresponde da uma rocha metabásica de granulometria fina, cor esverdeada, brechada, com fragmentos da ordem de milímetros até 10 centímetros de cloritito, englobados por uma matriz quartzosa rica em hidróxidos de ferro. Nas proximidades dessa metabásica estão sendo explorados dois filozes (GR - 23/24).

Uma ocorrência de rocha meta-últrabásica verificada situa-se no ponto PA - 101, nas imediações do filão da Serrinha (PA - 11) encaixado em tonalitos gnaissificados (PA - 191). Neste local a atividade garimpeira expôs uma rocha de coloração cinza-clara, com foliação proeminente evidenciando pelo menos duas fases de dobramentos superimpostas, caracterizadas por dobras isoclinais e em bengala. Nota-se nos blocos aflorantes (Foto 3) que a rocha está afetada por apófises, bolsões e venulações de material esbranquiçado de natureza quartzo-feldspatico.

As observações de campo e ao microscópio permitem verificar a existência de dois tipos petrográficos. A rocha mais antiga que pode ser classificada como metapiroxenito apresenta granulometria fina, textura granoblástica, sendo constituída por clinopiroxênio (35\%), parcialmente transformado em anfibólio $(30 \%)$ e plagioclásio (10\%). Quartzo (15\%) e feldspato potássico $(10 \%)$, do tipo microclínio e ortoclásio pertíticos, ocorrem principalmente associados às injeções graníticas, ocorrendo ao longo da foliação ou em vênulas englobando cristais de piroxênio e anfibólio. Em lâmina petrográfica observa-se a presença de resquicíos de um bandamento mineralógico, com alternância de leitos ricos em piroxênio (diopsidio) com leitos de plagioclásio, estes saussuritizados, com formação de epídoto, e sericita; como acessórios ocorrem titanita, apatita e opacos (Microfoto 3). 


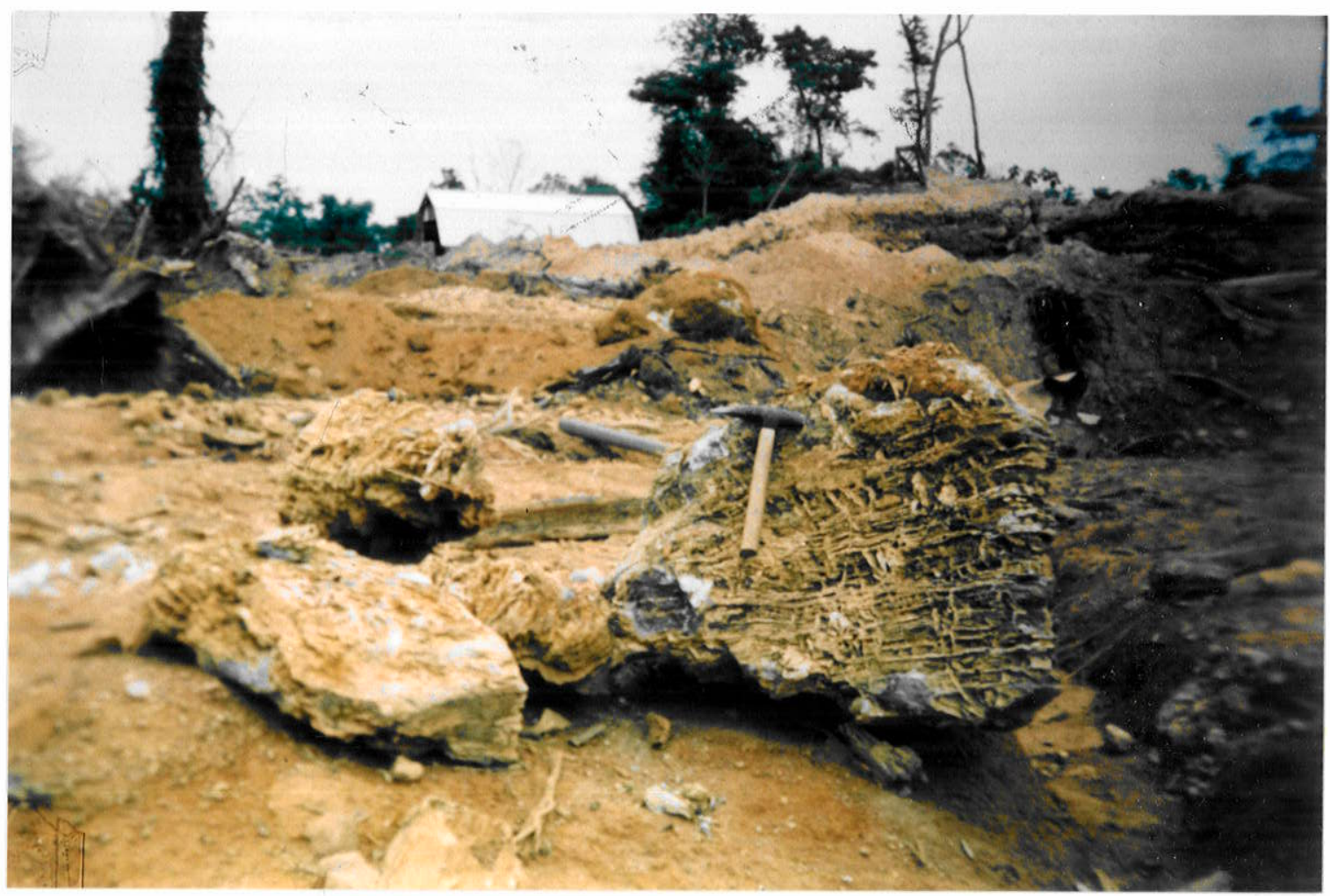

Foto 3: Amostra PA-101. Metapiroxenito com apófises e venulações de material quartzo-feldspático.

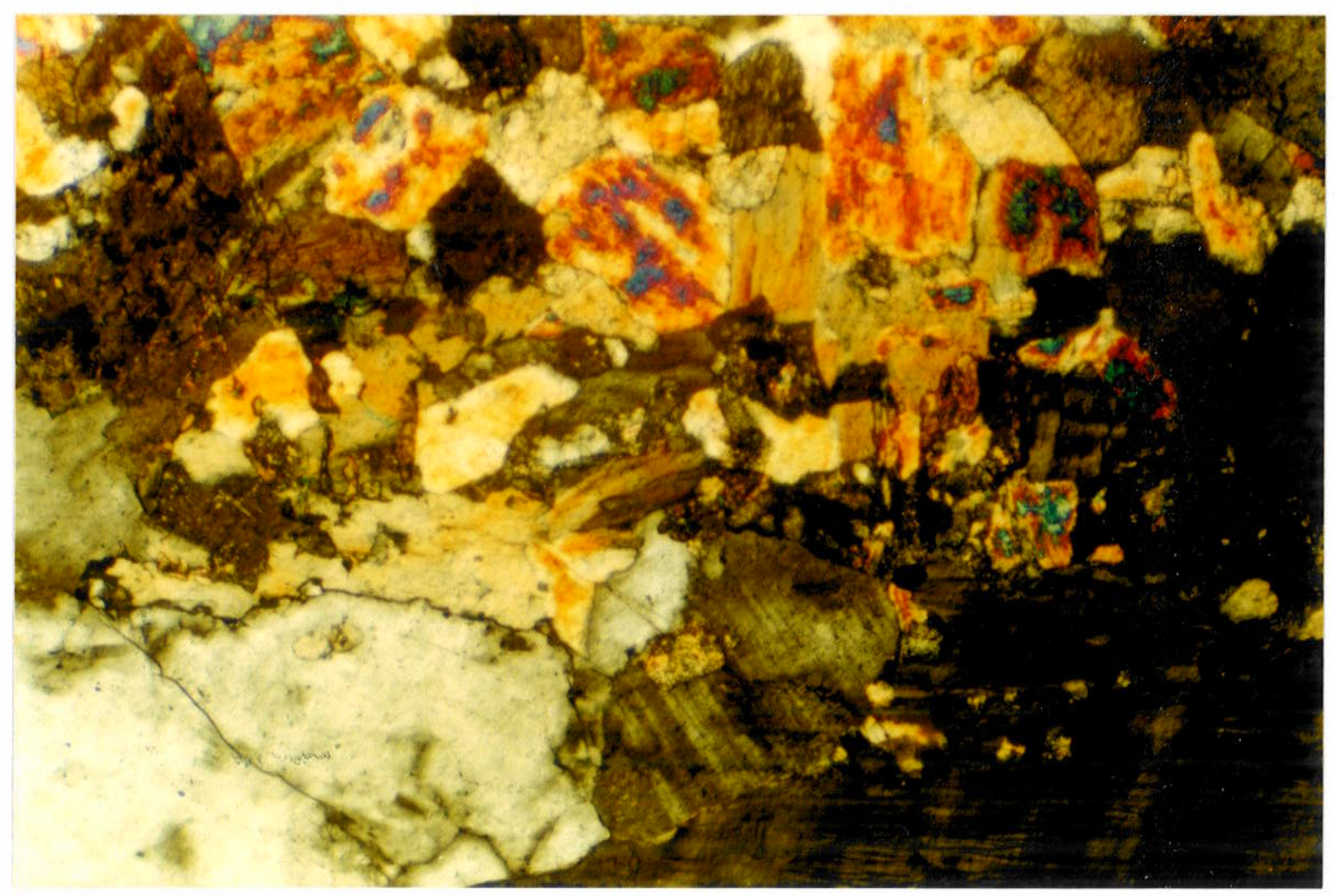

Microfoto 3: Amostra PA-101, aumento 78.75x, NX. Clinopiroxenito. 


\section{Filitos e Metarenitos}

Um conjunto de rochas meta-sedimentares detríticas afloram na extremidade sudoeste da área mapeada, pontos PA-200 e 201, conforme mapa geológico (Anexo 01).

Estas rochas estão representadas principalmente por filitos, metarenitos e metasiltitos, que ocorrem como pequenas cristas destacadas no terreno.

Os filitos são sericíticos, tem cores cinza-esverdeados a avermelhados, quando alterados. A estrutura mais proeminente é uma foliação do tipo clivagem ardosiana, com atitudes variando entre N25W a E-W. Veios de quartzo leitoso com espessuras de 15 a $30 \mathrm{~cm}$, com atitude $\mathrm{N} 30 \mathrm{E} / \mathrm{SV}$, cortam estas rochas. Localmente se observou um veio de quartzo cisalhado, com espessura espessura superior a 1 metro, apresentando box works e pseudomorfos de pirita, encaixado em meta-sedimentos cisalhados.

\section{3 - Granitóides Arqueanos}

$\mathrm{Na}$ área de pesquisa os granitóides de composição diorítica, tonalítica e granodioritica são os termos mais representativos, ocorrendo tanto nas cavas profundas abertas ao longo dos filões (caso dos pontos PA - 95, 122, 171, 186 e 172 e GR $-21,23,27$ e 28 ), como em elevações próximas aos divisores de águas (pontos GR - 03, 08, 38, 44 e 55 e PA - 129 e 146).

Apesar de não ser possível delimitar precisamente os contatos dessas rochas, nem verificar relações de contato diretas com outras unidades, supõe-se que se trata de intrusões na forma de batólitos ou stocks. As estruturas observadas mostram variações desde termos isótropos, pouco deformados, até anisótropos, com marcante orientação de biotita e hornblenda, com dobramentos localizados, evidenciando estreito relacionamento com os gnaisses do Complexo Xingu.

Localmente, esses granitóides apresentam elevada susceptibilidade magnética, caso das amostras coletadas nos pontos PA - 79, 97 e 144.

A composição modal dessas rochas está representada no diagrama QAP (Figuras 11 e 12), e os dados petroquímicos relacionados na Tabela 05.

A disposição dos Granitóides Arqueanos no diagrama modal (Figura 11), permite posicioná-los no grupo de granitóides com baixo K, de natureza cálcio-alcalina, tonalítica ou trondhjemítica, conforme Bowden et. al. (1984). Em termos comparativos, é possível correlacioná-los, em parte, aos Granitóides Arqueanos sódicos das regiões de Amapá e Altamira, citados por Dal'Agnol et. al. (1981), com os trends apresentados na Figura 06. 


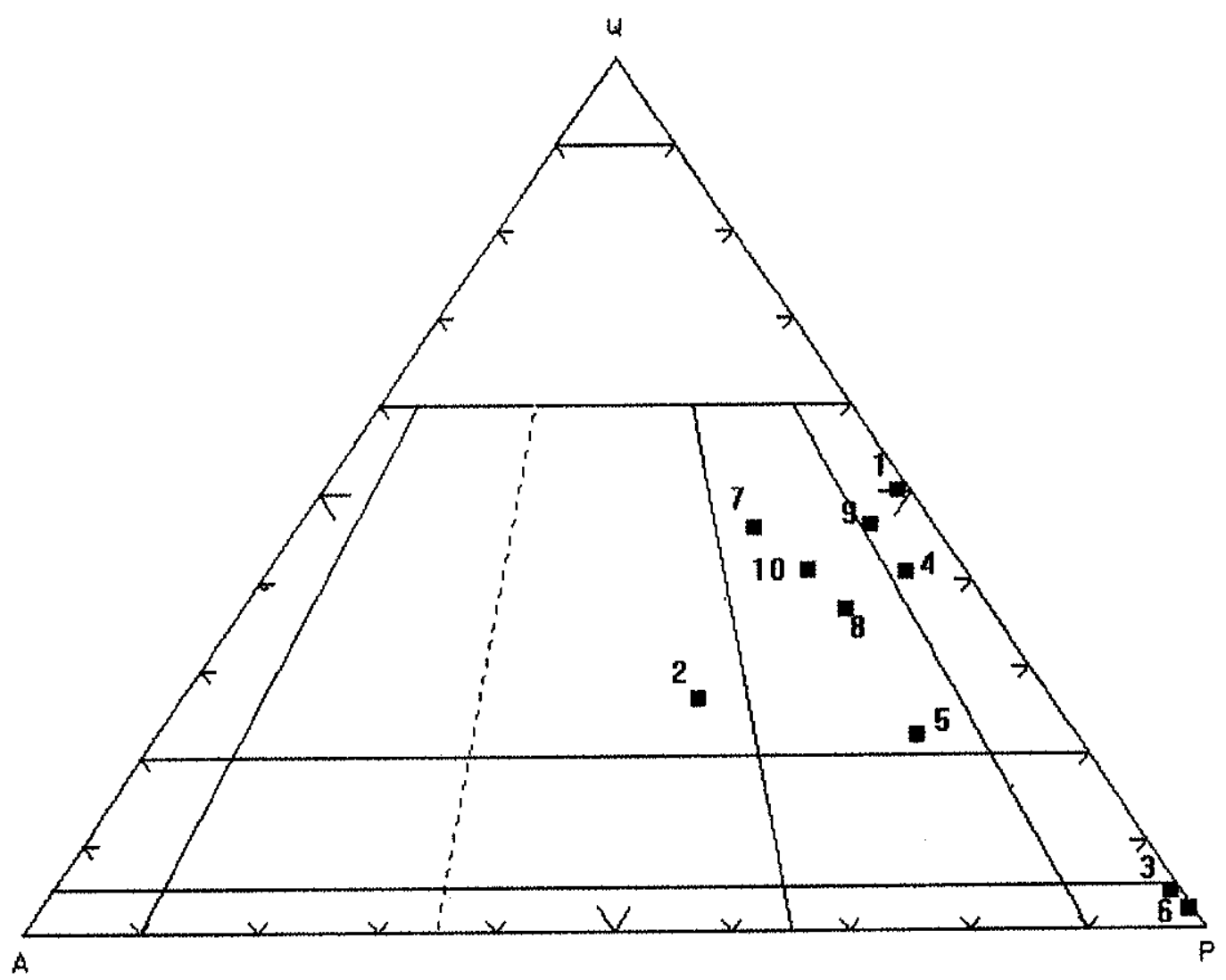

Figura 11. Composição modal dos Granitóides Arqueanos

1 GD-GR 03 Biotita Tonalito

2 GR-AJ 08 Hornblenda Granito

3 GR-AJ 05 Biotita - Hornblenda Diorito com Quartzo

4 - PA-AJ 122 Biotita Tonalito

5 PA-AJ 127 Sericita - Biotita - Clorita Granodiorito

6 PA-AJ 129 Epídoto - Hornblenda Diorito com Quartzo

7 PA-AJ 146a Biotita Granodiorito

8 PA-AJ 151 Epídoto - Biotita Granodiorito

9 PA-AJ 171 Biotita Tonalito

10 PA-AJ 172 Biotita Granodiorito

Fonte: Streickeisen, A.L. (1976) 


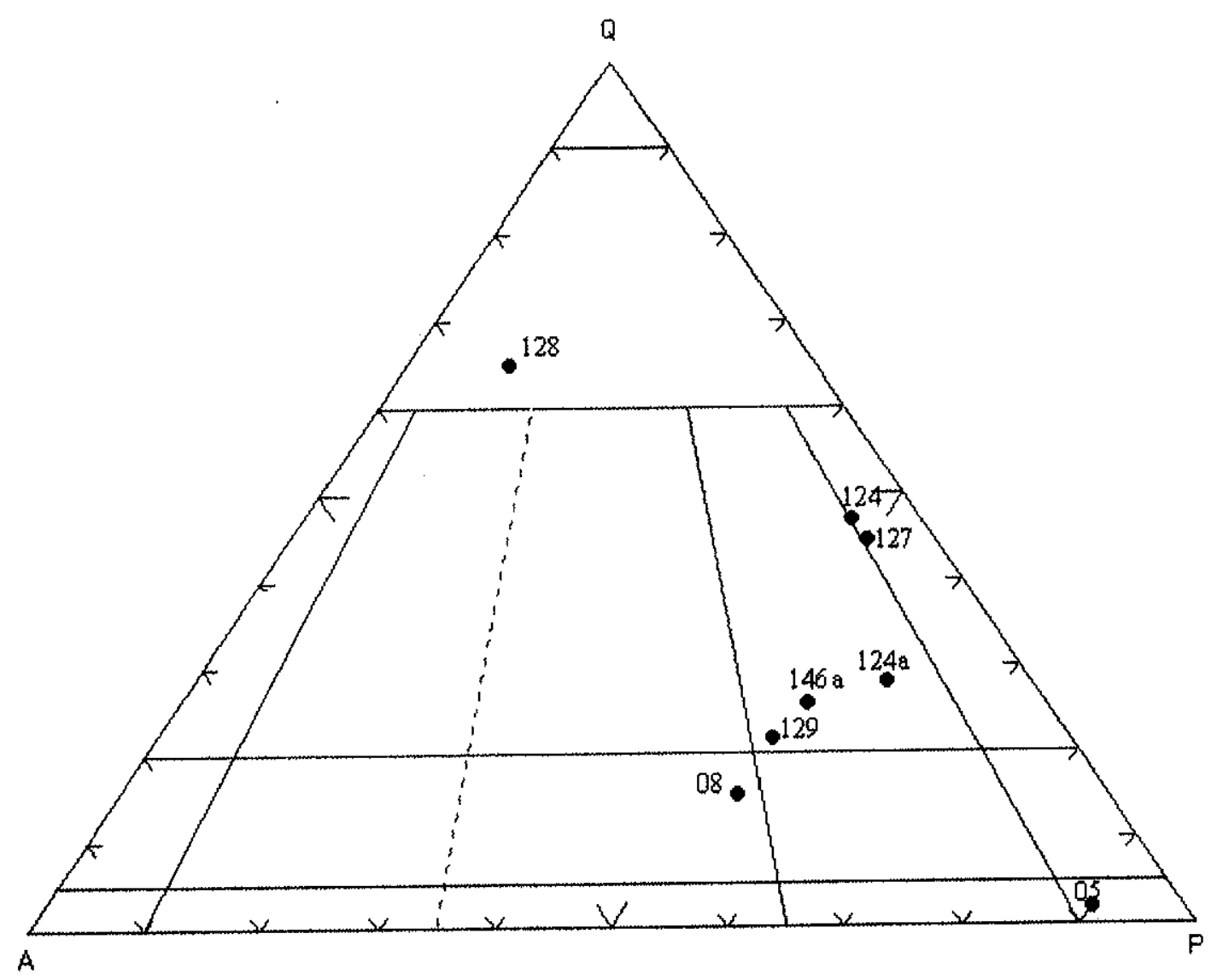

Figura 12: Composição modal dos Granitóides Arqueanos com base nos dados normativos, segundo critérios de Le Maitre (1989).
Amostra
Classificação petrográfica
QAP
Streickeisen (1976)
Le Maitre (1989)
GR 08 Hornblenda Granito
GR 05 Biotita-Hornblenda diorito
Quartzo Monzonito
PA124 Biotita Tonalito
Diorito
PA124a Biotita Tonalito
Tonalito
PA127 Sericita-Biotita-Clorita granodiorito
Granodiorito
PA128 Granitóide
Tonalito
PA129 Epídoto-Hornblenda diorito
Granito quartzoso
PA146a Biotita granodiorito
Granodiorito
Granodiorito 
Tabela 05: Analises quinicas, aorad (CIPH) e moda dos Granitöides arqueanos

\begin{tabular}{|c|c|c|c|c|c|c|c|c|c|c|}
\hline$\therefore$ Anostra & $6 r-03$ & {$\left[\begin{array}{rr}6 r-05 \\
1\end{array}\right]$} & $6 r-08$ & {$[\mathrm{~Pa}-722]$} & $P_{a}=124$ & $\begin{array}{r}p-124 \\
a\end{array}$ & Pa 12$\}$ & $\mid \begin{array}{r}\mid r-128 \\
2\end{array}$ & $P y-129$ & $\begin{array}{r}P a-146 a \\
z\end{array}$ \\
\hline 5102 & & 48,1 & 65.8 & & 68.0 & 64.2 & 56.6 & 68.8 & 65.9 & 65.2 \\
\hline $\mathrm{Al}_{2} \mathrm{O}_{3}$ & & 16.0 & 13.7 & & 12.5 & 15,6 & $14 . \overline{5}$ & 17.3 & 15.1 & 14.2 \\
\hline $\mathrm{Fe}_{2} \mathrm{OS}_{3}$ & & 5,4 & $1, ?$ & & 4.1 & 3,1 & 5.3 & 2.1 & 2.8 & 2.7 \\
\hline $\mathrm{FeO}$ & & 7.9 & 2,3 & & 4.0 & 2.7 & 5.5 & 0.4 & 1.1 & 2,2 \\
\hline 520 & & $?, 5$ & 2.5 & & 2,6 & 2.9 & 5.9 & 0.28 & $\overline{2,4}$ & 2.9 \\
\hline$\$ 190$ & & $4, ?$ & 1.4 & & 1.4 & 2.2 & 3,2 & 1.8 & 0.99 & $1 . ?$ \\
\hline $\mathrm{H}_{2} \mathrm{O}$ & & 3.5 & 5.4 & & 3.0 & 4,2 & 1.8 & 0.66 & 4.6 & 4.3 \\
\hline$k_{2} 0$ & & 1,7 & 3.9 & & 1.9 & 2.3 & 2.7 & 4,1 & 4.4 & $\sqrt{3.1}$ \\
\hline 160 & & 0,26 & 0.13 & & $0 . \pi$ & 0.05 & 0,14 & {$[0,65$} & 10.05 & 0,1 \\
\hline $\mathrm{TiO}_{2}$ & & 9,6 & 0.79 & & 0.66 & 0.63 & 1,1 & 0.06 & 0.52 & 0,73 \\
\hline$P_{2} 0_{5}$ & & 0.72 & 8,27 & & 0,06 & 0.2 & 0.85 & 10,05 & 0,68 & 0,2 \\
\hline$F$ & & 0.16 & 0.058 & & 0,135 & & 0.13 & & & \\
\hline$P_{1} F_{2}$ & & 1,48 & 2,17 & & 1.06 & 1,2 & 1.51 & & 1.9 & 2.1 \\
\hline 5 & & 0,11 & 0,006 & & 0.013 & 0,16 & 0,0082 & & 0.03 & \\
\hline ppllamostra & $6 r-03$ & $6 r-05 \mid$ & $6 R-08$ & Pa-12? & $9 \geqslant-124$ & $P a-124 A$ & Pa-12? & $8 a-128$ & $p a-129$ & $P_{A}-146_{A}$ \\
\hline (]) & & 2.10 & 82 & & 73 & & $6 ?$ & & & \\
\hline 5 & & & & & & 0.16 & & $0, \overline{03}$ & & \\
\hline Alu & & $N$ & in & & & H & & H & in & 0.04 \\
\hline As & & 2 & 3 & 2 & & 2 & & 2 & 4 & 2 \\
\hline 611 & & 2 & 12 & $?$ & & 18 & & 5 & 16 & 25 \\
\hline $\mathrm{Pb}$ & & 6 & 16 & 10 & & 16 & & 4 & 10 & 16 \\
\hline $2 n$ & & 78 & 66 & 40 & & 65 & & 13 & 49 & 73 \\
\hline L.d & & & & & & 12 & & 1 & & \\
\hline $\mathrm{Hi}$ & & 3 & 14 & 7 & 1 & 10 & $i$ & 4 & 6 & 12 \\
\hline $\mathrm{Cr}$ & & 6 & 34 & 18 & 23 & 32 & 17 & 5 & 12 & 50 \\
\hline$B d$ & & 195 & 146 & $14 ?$ & & 255 & & 92 & $7 ?$ & 120 \\
\hline 81 & & II & H & A & & 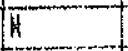 & & $x$ & 1 & $\pi$ \\
\hline 110 & & $650^{\circ}$ & $580^{\circ}$ & IN & & 22.0 & & 12,0 & 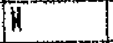 & 570 \\
\hline U & & 148 & 32 & 72 & & 80 & & 10 & 40 & 48 \\
\hline Co & & $20^{\circ}$ & 5 & 6 & & 12 & & & 5 & 8 \\
\hline$\xi r^{\prime}$ & & 690 & 279 & 453 & & & & & 535 & 434 \\
\hline form manostra & $6 i r-83$ & $6 r \cdots 05$ & $6 r-08$ & $p z-122)$ & $p a-124$ & $\beta p_{d}=12 \alpha_{A}$ & $\mid p a-127$ & $P a-128$ & $\mid \overline{p a-129}$ & $P d-146_{A}$ \\
\hline Quartzo & & 0,00 & $15,9 \mathrm{n}^{\circ}$ & & 35,71 & 19.31 & 23,58 & 48.24 & 18,0 & 21.06 \\
\hline Or toclasio & & 10.32 & 20,66 & & 11.42 & 17.33 & $16, \overline{9 ?}$ & 25.35 & 26.39 & 18,33 \\
\hline Albita & & $29.7 ?$ & 46.71 & & 25,59 & 36.01 & 9,60 & 5.80 & 39.30 & 37.18 \\
\hline Gnortita & & 23,89 & 3.33 & & 12,76 & 13,33 & 25,05 & 1.14 & 7.57 & 10.68 \\
\hline Corindon & & - & - & & - & 0.75 & 0.94 & 11.31 & 0.08 & \\
\hline Hiperstenio & & & & & & & & & & \\
\hline Biopsidio & & 8,15 & 6.31 & & - & - & - & - & $=$ & 2.18 \\
\hline Gagnetits & & 8,04 & 2,53 & & 6,04 & 4.55 & 7,93 & 1,37 & 2,23 & 4,02 \\
\hline Olivina & & 3,0 &  & & & $\ldots$ & - & $=$ & 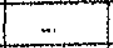 & - \\
\hline Tilaenita & & 3,12 & 1.54 & & 1,27 & 1.21 & $2, \overline{16}$ & 0,10 & 1,0 & 1,42 \\
\hline Apatita & & 1.75 & 0.60 & & 0.14 & 0.48 & 2,08 & 0,13 & 1.63 & $0, \overline{49}$ \\
\hline Cronits & & $\ldots$ & - & & $\ldots$ & 0.01 & $\approx$ & - & - & $=$ \\
\hline Hefelina & & 0.49 & 0.19 & & 0.04 & - & 0.59 & - & - & $\ldots$ \\
\hline Halita & & 0.04 & 0,01 & & 0.01 & - & 0.01 & - & 0.01 & 0.01 \\
\hline lieratita & & $\ldots$ & 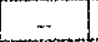 & & - & - &  & 1.25 & - & - \\
\hline
\end{tabular}


Tabela 05: Analises quinicas, norma (CIPH) e moda dos franitoides arqueanos, (Continuaso)

\begin{tabular}{|c|c|c|c|c|c|c|c|c|c|c|c|c|}
\hline 10 व & anostra & $(6 r-03$ & $6 r-05$ & $6 \mathrm{r}-08$ & $\mathrm{~Pa}_{\mathrm{a}}=122$ & $\begin{array}{r}P a-124 \\
(3)\end{array}$ & $P+127$ & $p a-129$ & $\mathrm{~Pa}-146 \mathrm{~A}$ & $\mathrm{~Pa}-451$ & $\begin{array}{r}p a-171 \\
(3)\end{array}$ & $\begin{array}{r}P a-172 \\
(3)\end{array}$ \\
\hline \multicolumn{2}{|l|}{ Quartzo } & 35 & 2 & 20 & 35 & 35 & 15 & 2 & 35 & 30 & 25 & 30 \\
\hline \multicolumn{2}{|c|}{ F. Alcalino } & 1 & - & 75 & (4) & 10 (4) & 12 & - & $\begin{array}{ll}15 & (4) \\
\end{array}$ & 10 & 10 & 15 \\
\hline \multicolumn{2}{|c|}{ Plagioclasio } & 30 & 50 & 35 & 45 & 40 & 35 & 35 & 30 & 40 & 40 & 35 \\
\hline \multicolumn{2}{|c|}{ biotita } & 25 & 20 & $=$ & 10 & 佔 & 10 & $=$ & 13 & 10 & 15 & 20 \\
\hline \multicolumn{2}{|l|}{ Clorita } & 05 & 1 & 1 & H & & 15 & $=$ & 1 & 1 & & \\
\hline \multicolumn{2}{|c|}{ Hornblenda } & $=$ & 20 & 10 & & & $=$ & 30 & $ت$ & - & & \\
\hline \multicolumn{2}{|l|}{ Sericita } & 3 & 1 & 2 & 1 & & 18 & 2 & 2 & 3 & & \\
\hline \multicolumn{2}{|l|}{ Titanita } & - & 8 & 1 & II & & - & 3 & $=$ & $=$ & & \\
\hline \multicolumn{2}{|l|}{ Apatita } & B & 1 & 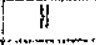 & $n$ & & - & 1 & 4 & 8 & & \\
\hline \multicolumn{2}{|l|}{ Epidota } & 1 & 2 & rin & 1 & & 2 & 25 & 2 & 5 & & \\
\hline \multicolumn{2}{|l|}{ Zircyo } & - & - & 8 & II & & 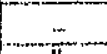 & $=$ & 8 & - & & \\
\hline \multicolumn{2}{|c|}{ Carbonato } & $\approx$ & 8 & 4 & $=$ & & 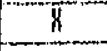 & $\ldots$ & - & - & & \\
\hline \multicolumn{2}{|c|}{ Pirosenio } & $=$ & 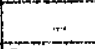 & $\cdots$ & $=$ & & $=$ & - & - & $=$ & & \\
\hline \multicolumn{2}{|l|}{ Opacos } & $\pi$ & 3 & 2 & 3 & & 1 & 3 & 1 & 1 & & \\
\hline
\end{tabular}

\section{Lesenda}

(1) - Aalises quinicas efetuadas no GeOLAB

(2) - Anälisas quilaicas efetuadas no Lanla/CPBH

(3) - Hoda por calorimetyia

(4) - Enriquecisento potassice (FK)

8 - Hineral con inoda< $\%$

H - Ha de tectado

L - Henor que o valor registrado fir 03 - Biotita tonalito

Gir 05 - Biotila - Hornblenda diorito com quartzo

far 08 - Nornblenda granito

Pa 122 - Biotita tonalito

Pa 124 - Biotita tonalito

Pa 127 - Sericita - Biotita - Clorita granodiorito

$\mathrm{Pa} 129$ - Epidoto - Hornblenda diorito colit quartzo

$P$ a $146 a-$ Biotita granodiorito

Pa 451 - Epidoto - Biotita granodiorito

Pa 771 - Biotita tomalito

Pa 172 - Biotita granodiarito 
Os dados modais apresentados (Tabela 05 e Figura 11) não permitem definir nesta série magmática cálcio-alcalina, um trend evolutivo típico. No entanto, é possível sugerir a existência de um trend com dioritos, tonalitos e granodioritos.

As análises químicas dos Granitóides Arqueanos, (Tabela 05), permite observar que eles apresentam teores de $\mathrm{K}_{2} \mathrm{O}$ baixos a moderados, entre 1,7 e 3,4. A proporção molecular $\mathrm{Al}_{2} \mathrm{O}_{3} /\left(\mathrm{CaO}+\mathrm{K}_{2} \mathrm{O}+\mathrm{Na}_{2} 0\right)$ é menor que 1,1 , evidenciando o caráter metaluminoso a ligeiramente peraluminoso desses granitóides (Figura 13).

Com relação aos teores de $\mathrm{Si}, \mathrm{Fe}$ e $\mathrm{Mg}$ (Figuras 14 e 15), é possível constatar a existência de dois grupos distintos, um mais rico em sílica $\left(\mathrm{SiO}_{2}\right.$ entre 65,8 e 68,8$)$ e álcalis $\left(\mathrm{Na}_{2} \mathrm{O}+\mathrm{K}_{2} \mathrm{O}\right)$ de afinidade cálcio-alcalina e outro mais pobre em sílica $\left(48,1\right.$ a 64,2) e mais rico em $\mathrm{FeO}$ e $\mathrm{TiO}_{2}$ de afinidade toleitica.

No terreno, a ocorrência dos Granitóides Arqueanos está frequentemente associada a superficies arrasadas, suavemente onduladas, com desenvolvimento de espesso solo marrom-avermelhado.

\section{Tonalitos Gnaíssicos}

Afloram principalmente na região do córrego Gavião e grota do Pará (PA - 171), córrego do Enforcado (PA - 97/ 122), Baixão Velho (PA - 11/191), Baixão Novo (PA - $95 / 144$ ), na localidade de Alto Alegre (GR - 03/29/38/55), e certamente em vários outros locais não passíveis de observação devido ao elevado grau de intemperismo sobre essas rochas.

São rochas leucocráticas a mesocráticas, equigranulares, médias a grossas, de coloração cinza, isótropas a gnaíssicas, com textura granoblástica e granolepidoblástica. A mineralogia verificada a partir da descrição de 04 lâminas, está representada por plagioclásios - oligoclásio e andesina (35 - $45 \%)$, quartzo (30 - $35 \%$ ), biotita $(10-25 \%$ ) e como acessórios ocorrem clorita, sericita, hornblenda, epídoto, feldspato potássico, apatita, titanita, pirita e opacos.

São marcante nessas rochas os efeitos provocados pelas mega-zonas de cisalhamentos de direção N-NW, que cortam as mesmas gerando uma variedade de rochas cataclásticas, com reflexo nas zonas menos deformadas (pods) marcado pela intensa sericitização dos plagioclásios e progressivas feições de recristalização dinâmica nos grãos de quartzo, com formação de sub-grãos em faixas (Microfoto 4).

A biotita de cor marrom a parda apresenta-se por vêzes, com as bordas cisalhadas e cloritizadas. O feldspato potássico ocorre como inclusões no plagioclásio ou se restringe as porções mais leucocráticas da rocha, notoriamente associadas a intrusões de apófises de granito pegmatítico (PA - 127a), que parece ter provocado localmente, enriquecimento potássico nos tonalitos (PA - 122), transformando-os em biotita-sericita-clorita granodiorito protomilonítico (PA - 127). 




Figura 13. Indice de aluminosidade. Grantóldes Arqueanos.



Figura 14 . Dlagrama FeO/MgO/Na $\mathrm{O}_{2}+\mathrm{K}_{2} \mathrm{O}$. Granitobides Arqueanos. 


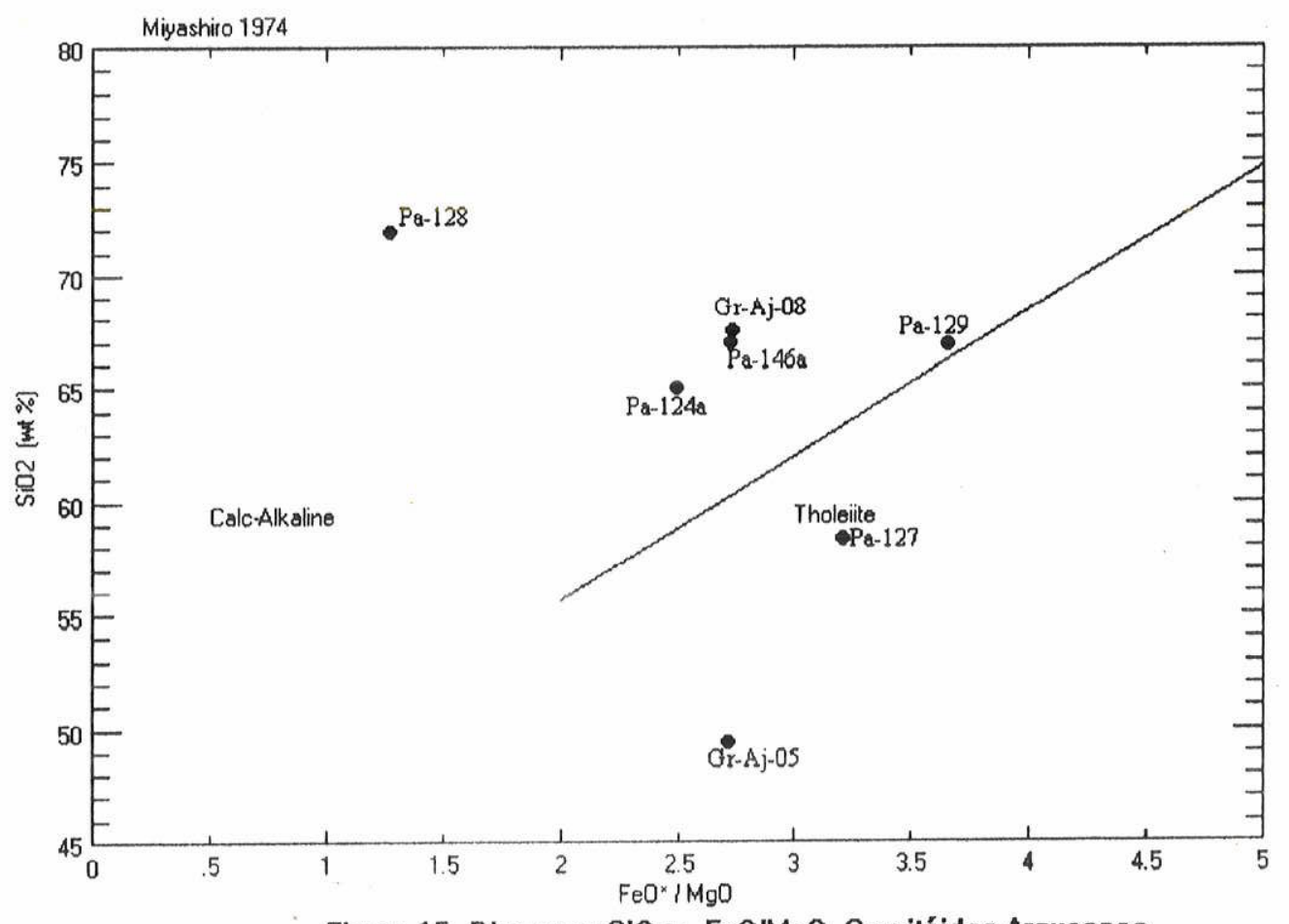

Figura 15. Diagrama $\mathrm{SiO}_{2} \times \mathrm{FeO} / \mathrm{MgO}$. Granitóides Arqueanos



Microfoto 4: Amostra PA - 124, aumento 78.75, NX.

Biotita tonalito protomilonítico. Contato entre grãos de plagioclásio saussuritizados e biotita, esta apresentando-se com lamelas arqueadas e bordas fraturadas. Nota-se ainda a recristalização de quartzo em sub-grãos. 


\section{Granodioritos Gnaíssicos}

São rochas leucocráticas, orientadas a gnaissificadas, de coloracão cinza claro, equigranulares, granulometria média a grossa, por vezes com megacristais de microclínio da ordem de $1 \mathrm{~cm}$ (Foto 4).

As amostras observadas nos pontos PA 99/146/151/152 e 154 são as mais características, sendo constituídas por oligoclásio (30 - 40\%), quartzo (32 $35 \%)$, biotita $(10-15 \%)$ e feldspato potássico (10 - 15\%); o plagioclásio encontrase alterado para sericita $(2-5 \%)$ e em algumas amostras é do tipo antipertítico (PA - 146).

O quartzo apresenta-se com extinção ondulante e, localmente, em faixas miloníticas milimétricas, ocorre em ribbons associados a cristais deformados de plagioclásio e biotita. O feldspato potássico é o microclínio e como minerais acessórios, ocorrem epídoto, sericita, apatita, clorita e pirita.

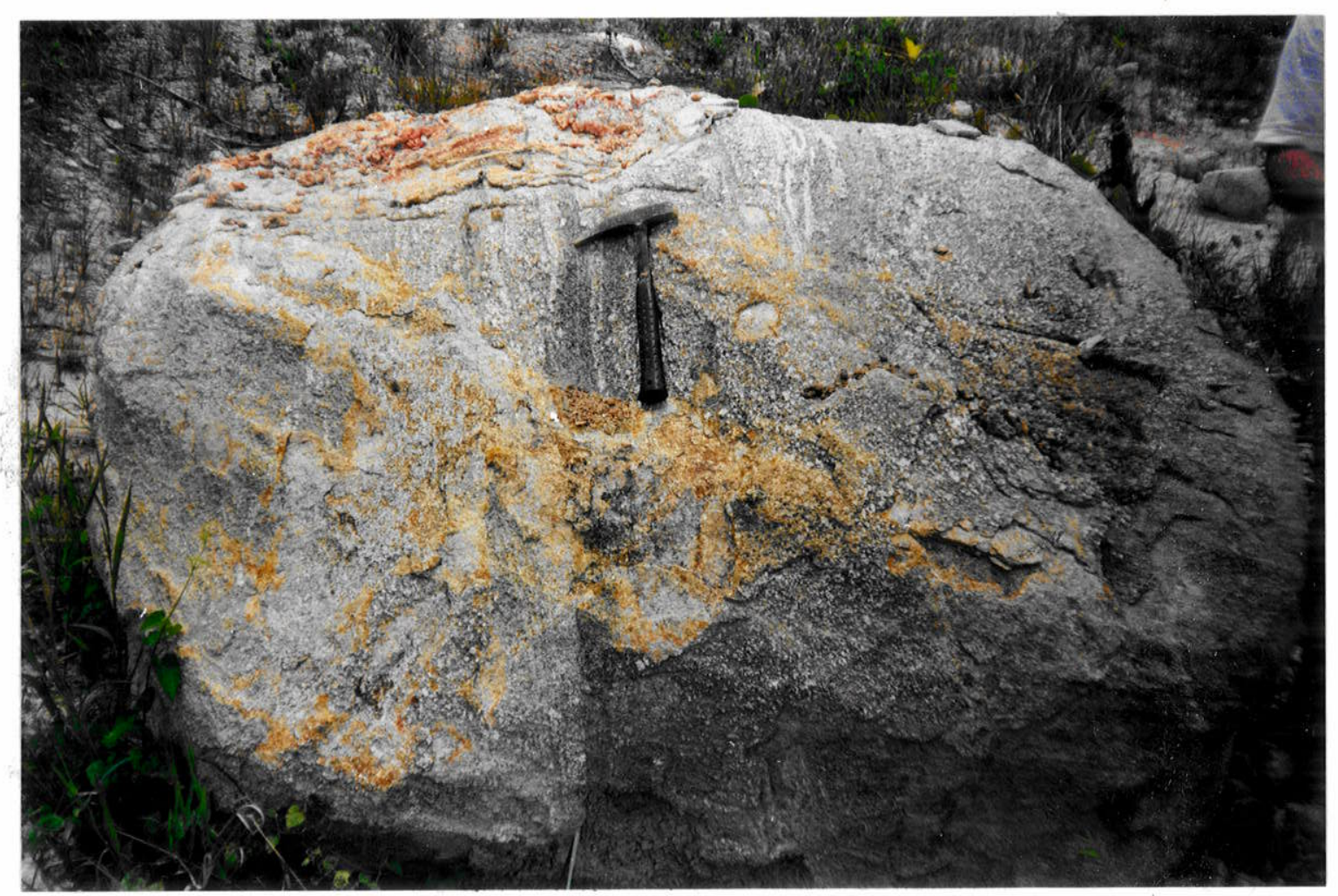

Foto 4: Amostra PA - 152 Granodiorito Gnaíssico.

Bloco apresentando um contato gradacional entre uma rocha leucocrática de composição granodiorítica e outra mesocrática de natureza, quartzo diorítica.

\section{Dioritos Gnaíssicos}

São rochas de coloração cinza escuro a esverdeado, observadas apenas em matacões isolados, nos pontos PA-129/186 e GR -05/28/44, com resquícios de orientação evidenciada pelo alinhamento de ripas de hornblenda (PA - 
129) ou com incipiente bandamento gnaíssico ( $G R$ - 05). A granulometria é fina a média e a textura granoblástica.

São constituídas essencialmente por andesina (35 - 50\%), hornblenda $(20-30 \%)$, biotita $(10-20 \%)$, epídoto $(02-25 \%)$ e tendo como minerais acessórios e de alteração; titanita, quartzo, opacos (ilmenita, magnetita ?), sericita e clorita.

$\mathrm{Na}$ amostra PA - 129, o plagioclásio encontra-se transformado em epídoto e sericita, caracterizando um retrometamorfismo do fácies anfibolito para o fácies xisto verde. A titanita ocorre como cristais isolados ou inclusões nos planos de clivagem da hornblenda.

\section{Granitos Gnaíssicos}

Ocorrem em um único afloramento, como um hornblenda microgranito (GR-08), bastante deformado, com enclaves micro-granulares centimétricos, alongados e ricos em anfibólios, aflorantes nas proximidades da maior ocorrência de talco-clorita xisto da região (GR-07).

O microgranito é uma rocha de coloração rósea esverdeada, com orientacão proeminente evidenciada pelos enclaves microgranulares estirados e sub paralelos ao alinhamento dos megacristais milimétricos de plagioclásio e quartzo. Os dados químicos apresentados na Tabela 04 , com $\mathrm{Na}_{2} \mathrm{O}>\mathrm{K}_{2} \mathrm{O}\left(\mathrm{K}_{2} \mathrm{O} / \mathrm{Na}_{2} \mathrm{O}=\right.$ 0,62 ) e a natureza leucocrática da rocha, evidenciam uma provável afinidade trondhjemitica (Foto 5).

A rocha apresenta textura porfiroclástica protomilonítica, sendo constituída por andesina $(35 \%)$; feldspato potássico pertítico $(25 \%)$ com inclusões de plagioclásio e hornblenda ( $10 \%)$ verde, porquilítica, com inclusões de quartzo e feldspato. Como minerais acessórios ocorrem ilmenita que tem as bordas alteradas para titanita, sericita e clorita. Verifica-se a presença de carbonato, na forma de veios e vênulas que quando lixiviados deixam a rocha com inúmeras cavidades, inclusive sugerindo a existência de outros minerais que podem também terem sido lixiviados.

A presença de uma matriz muito fina, de composição similar, totalizando cerca de $35 \%$ do volume de rocha, associado a feições que evidenciam inexistência de deformacão intensa, sugerem que essas rochas sofreram um rápido resfriamento. É provavel, portanto que o alinhamento dos cristais ocorreu em função do fluxo magmático, com a cristalização de um microgranito envolvendo os enclaves e os mega-cristais de plagioclásio. 


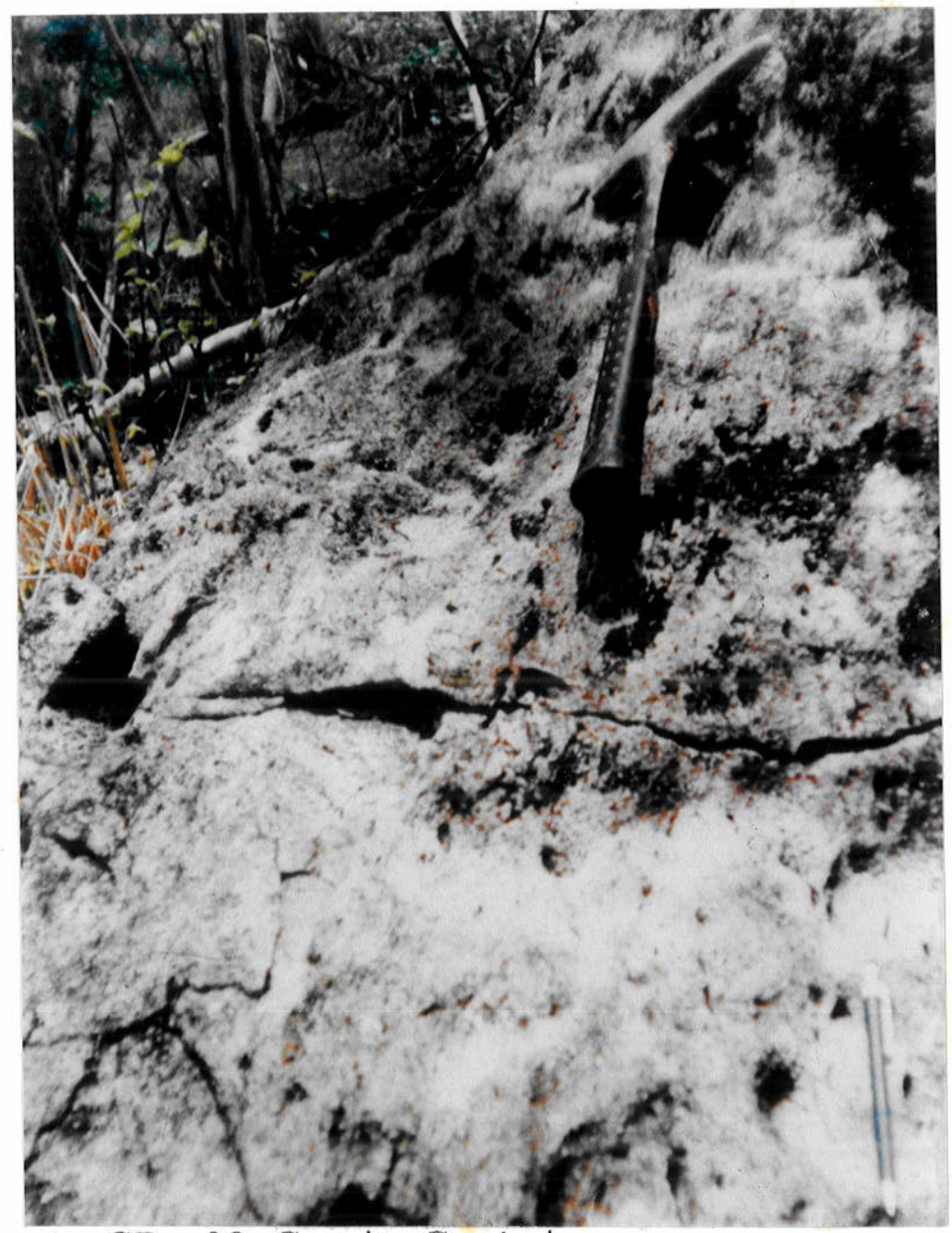

Foto 5: Amostra GR - 08. Granito Gnaíssico.

Rocha granítica com orientação evidenciada pelo alinhamento de enclaves microgranulares ricos em hornblenda e mega-cristais de plagioclásio.

\section{4 - Zonas de Cisalhamentos Dúcteis}

Essa unidade compreende uma espessa faixa de rochas cataclásticas resultantes da deformação progressiva ao longo de zonas preferenciais de encurtamento crustal, submetidas ao mecanismo de cisalhamento simples, gerando principalmente, rochas miloníticas.

A princípio, esse mega-sistema de cisalhamento, pode ser posicionado e interpretado como uma feição típica relacionada à evolução dos terrenos granito-gnaíssicos Arqueanos, devendo inclusive, ser verificado seu relacionamento com outras estruturas crustais, tendo em vistas que muitas vezes essas zonas aparecem limitando terrenos ou mesmo placas crustais (Daly, 1988). Concepção que, de certa forma, alinha-se com o posicionamento da região, situada na extremidade sudoeste da província Amazônica Central.

A morfologia em mapa e o afloramento dessas zonas de cisalhamento sugerem a existência de um padrão com várias faixas cisalhantes que se interceptam, configurando formas anastomosadas e sinuosas ao conjunto, com pods, na forma de amêndoas, passiveis de observação em todas as escalas (Foto 6, e mapa geológico Anexo 01). 


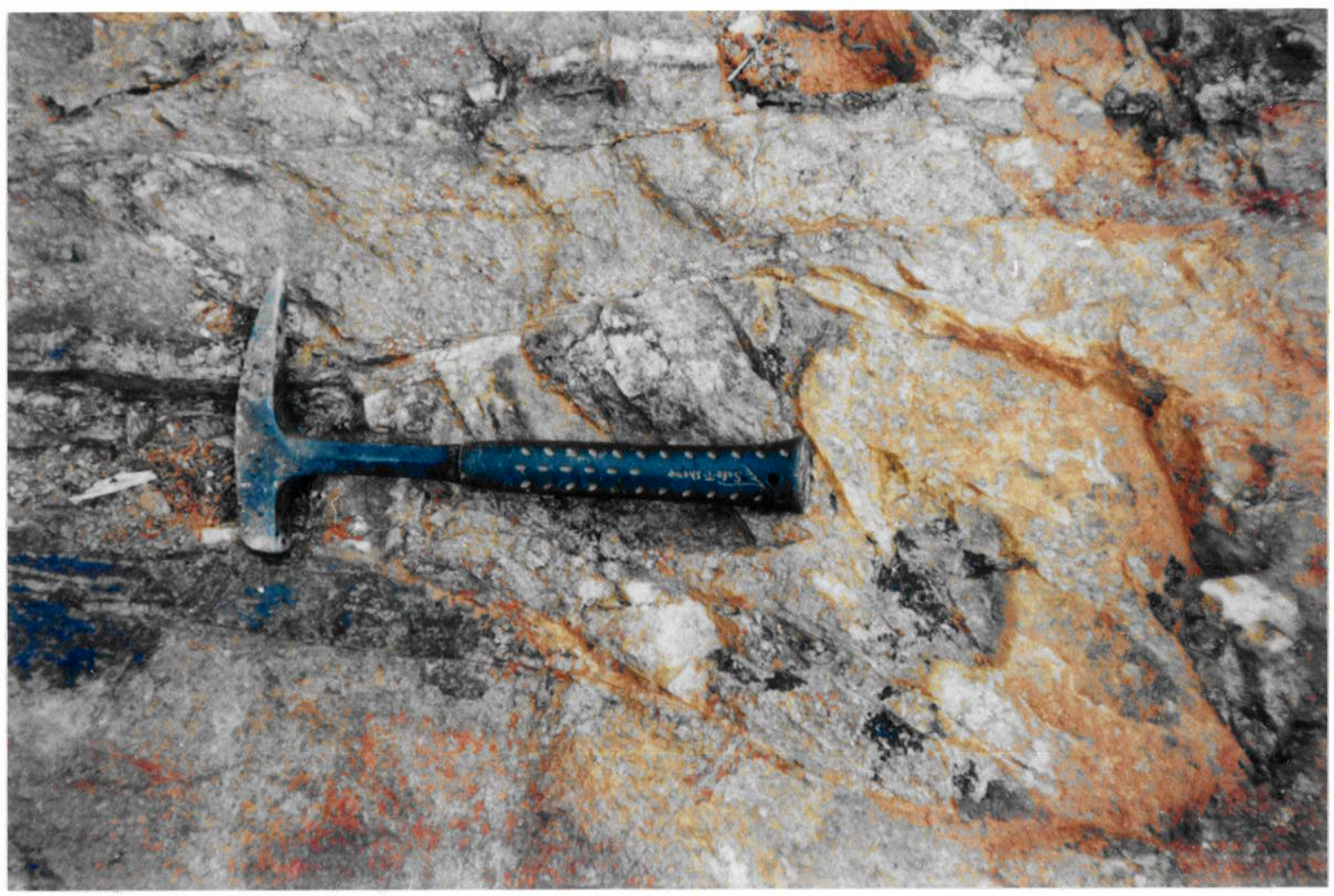

Foto 6: Amostra PA-156.

Granito afetado por bandas de cisalhamento sinuosas com foliação "sm"N50E/70SE, circundando pods, com desenvolvimento de incipiente foliação "sc" - N65W/80SW. Veios de quartzo sacaroidal (N45E/80NW) ocorrem sub-paralelos a foliação "sm".

$\mathrm{Na}$ área, a estruturação dessas zonas mostra um nítido trend N-NW, provavelmente estas zonas estão subordinadas a estruturas regionais de direção WNW, que limitam este segmento cratônico, e estão relativamente impressas através da configuração das estruturas tectônicas que limitam a borda sul do Graben do Cachimbo e a borda norte do Graben do Caiábis.

A disposição geométrica das foliações miloníticas e dos filões, frequentemente subverticais, e o predomínio de micro dobras e lineações de estiramento com eixos sub-horizontais, evidenciam o predomínio de movimentação transcorrente. Localmente, constitui uma das raras expressões de relevo na região, sobressaindo como um conjunto de cristas alinhadas segundo a direção N-NW, sustentadas principalmente por quartzo milonitos, micro brechas e granitóides cisalhados.

Essas zonas de cisalhamentos afetam principalmente os Granitóides Arqueanos e sua longa história deformacional pode ser atestada pela presença de inúmeras estruturas e litologias, tais como: bandas de cisalhamentos métricas 
dobradas assimetricamente, (PA - 125), brechas tectônicas (PA - 141/166 e GR 06), zonas de silicificação, superficies estriadas, veios de quartzo (de diversos tipos e gerações), diques de metabásicas, microgranitos e apófises de granitos pórfiros. As estruturas e litologias citadas posicionadas dentro e/ou espacialmente subordinadas às zonas de cisalhamentos dúcteis, evidenciam a longa história evolutiva dessas faixas, como regiões preferenciais sujeitas a fenômenos de reativação e acomodação, com alternância de períodos e/ou mesmo subambientes, sujeitos tanto a regimes compresivos (transpressão), como distensionais (transtensão). Essas megamestruturas de cisalhamentos foram posicionadas dentro de um contexto de evolução global dos terrenos Arqueanos, embora as feições supracitadas evidenciam reativaçð̃es, mesmo que discretas, e em condições dúcteisrúpteis, durante o Proterozóico.

Nas regiões intensamente deformadas existe uma grande homogeneidade petrográfica representada principalmente por quartzo milonitos, com foliações "Sm" e "c", frequentemente proeminentes. Essas rochas, apresentamse com tonalidades amareladas, avermelhadas e esverdeadas, com blocos de formas romboédricas, silicificadas, com intensa percolação de óxidos de ferro ao longo dos planos de foliação e fratura.

Esses quartzo milonitos são constituídos principalmente por quartzo $(30-50 \%)$ e sericita $(40-50 \%)$, e subordinadamente, clorita, biotita, moscovita, zircão, opacos (óxidos) e mais raramente pirita (Tabela 06).

Nessas rochas, a intensidade dos processos deformativos reflete-se principalmente nos grãos de quartzo, dispostos segundo formas alongadas e sigmoidais, com textura granoblástica ou milonítica e diversas feições de recristalização que evidenciam o incremento da taxa deformacional, como contatos denteados, extinção ondulante em faixas, junções tríplices, quartzo recristalizado em sub grãos e quartzo em forma de ribhons. São exemplos típicos as amostras PA05/08/11/42/53/55/60/63/86/90/105/ 114/117/119/121/123/140/142/150/153 e 169; GR-11 e 15 (Microfoto 5).

Os dados petroquímicos dos milonitos PA-119 e 123 e GR-15, apresentados na Tabela 06 , evidenciam um relativo enriquecimento em $\mathrm{SiO}_{2}(80,3$ a 94,8\%) e empobrecimento dos demais elementos. A amostra PA-123, com teores mais elevado de $\mathrm{Al}_{2} \mathrm{O}_{3}(12,9 \%)$ e $\mathrm{K}_{2} \mathrm{O}(3,5 \%)$, reflete a maior quantidade de sericita, da ordem de $45 \%$.

Nas zonas menos deformadas subordinadas às estruturas de cisalhamento é possível identificar termos litológicos que preservam a estrutura granítica, mas tiveram a paragênese primária transformada, com geração de granitóides localmente foliados, de textura protoclástica e protomilonítica, constituídos principalmente por sericita e quartzo recristalizados, com clorita, óxidos de ferro e cristais reliquiares de feldspato e biotita (amostra PA05/36/80/86/104/128/144; Microfoto 6). 


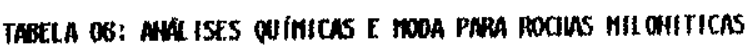

\begin{tabular}{|c|c|c|c|c|c|c|c|c|c|c|c|c|c|c|c|}
\hline 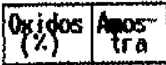 & $p A-\infty$ & $P A-119$ & $\begin{array}{r}P A 166 \\
?\end{array}$ & $P A-72$ & $P A-80$ & $\langle P A-86$ & $\mid 12-104$ & $P A-121$ & $\mathrm{PA}-123$ & $P A^{-144}$ & $\begin{array}{r}P A-105 \\
2 \\
\end{array}$ & $P h-140$ & $\begin{array}{r}6 A-06 \\
2\end{array}$ & $6 R^{-11}$ < & $6 \mathrm{R} \cdot 45$ \\
\hline $510_{2}$ & & 31,0 & 91,5 & & & & 56,7 & & 80,3 & & 41,3 & & 76,9 & $\{2,7$ & $M, 8$ \\
\hline Ale03 & & 1,2 & 1,1 & & & & 14,2 & & 12,8 & & 30,2 & & 6,6 & 3,8 & 12,3 \\
\hline $\mathrm{F}_{0203}$ & & 5,2 & 4.8 & & & & 1,6 & & 0,58 & & 6,6 & & 7,7 & 1.1 & 13,4 \\
\hline 700 & & 0,25 & 0,14 & & & & 4,9 & & 0,14 & & 0,4 & & 0,86 & 0,07 & 6,1 \\
\hline $\mathrm{CaO}$ & & 0,09 & 0,28 & & & & 0,24 & & 0,05 & & 0,14 & & 0,14 & 10,05 & 6,2 \\
\hline 190 & & 0,1 & 10,85 & & & & 9,9 & & 0,10 & & 0,83 & & 1,7 & 0,18 & 5,2 \\
\hline $\mathrm{H}_{2} \mathrm{O}$ & & 0,03 & 10,05 & & & & 0,05 & & 0,12 & & $0,5 A$ & & 10,05 & 0,03 & 0,4 \\
\hline$K_{20}$ & & 0,17 & 0,24 & & & & 1,9 & & 3,5 & & 10,2 & & 0,24 & 1,1 & 1,3 \\
\hline ho & & 0,02 & 0,05 & & & & 0,17 & & 0,01 & & 10,05 & & 0,12 & 0,02 & 0,21 \\
\hline $\mathrm{TiO}_{2}$ & & 0,07 & 0,1 & & & & 0,21 & & 0,08 & & 0,94 & & 0,73 & 0,05 & 0,94 \\
\hline$P_{2} \theta_{5}$ & & 0.05 & $(0,05$ & & & & $0,5 ?$ & & 0,05 & & 0,00 & & 0.18 & 10,05 & 0,17 \\
\hline $\mathrm{Cr}_{203}$ & & 0,005 & & & & & & & 0,003 & & & & & 10,003 & \\
\hline Hio & & 10,003 & & & & & & & 10,0003 & & & & & $1.0,003$ & \\
\hline I & & 0,014 & & & & & & & 0,018 & & & & & 0,079 & \\
\hline PF & & 4,75 & & & & & & & 2,10 & & & & 4,3 & 0,91 & \\
\hline 5 & & 0.5 & 0,75 & & & & $B, 16$ & & 0,006 & & 0,16 & & & $1.0,005$ & \\
\hline 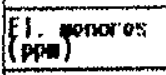 & PNOS & PA1t9 & PAsto & ph7? & PASO & PABP & PATOA & PA121 & PAt23 & PA144 & PPA 105 & PM140 & GAPB & GR11 & 6815 \\
\hline CI & & 1.20 & & & & & & & 1.20 & & & & & 28 & 26 \\
\hline 5 & & & & & & & & & & & & & & & \\
\hline w & & H & $H$ & & & & H & & $\mathrm{H}$ & & $\mathrm{H}$ & & $\mathrm{H}$ & & $\mathrm{H}$ \\
\hline As & & & & & & & & & & & & & & 45 & $T$ \\
\hline Cu & & & 11 & & & & 165 & & & & 32 & & 10 & & \\
\hline$\overline{P b}$ & & & 4 & & & & 8 & & & & 6 & & 8 & & \\
\hline $2 n$ & & & 3 & & & & 194 & & & & 5 & & 64 & & \\
\hline La & & & 1 & & & & & & & & 19 & & & & \\
\hline $\mathrm{Hi}$ & & & 5 & & & & 250 & & & & 12 & & 20 & & \\
\hline $\mathrm{Cr}$ & & & 6 & & & & 400 & & & & 42 & & 94 & & \\
\hline $\mathrm{Ba}$ & & & 16 & & & & 128 & & & & 148 & & 11 & & \\
\hline $\mathrm{Bi}$ & & & $H$ & & & & $\mathrm{~N}$ & & & & $\mathrm{~N}$ & & $\mathrm{H}$ & & \\
\hline $\mathrm{No}_{0}$ & & & $1.2,0$ & & & & 12,0 & & & & $H$ & & 990 & & \\
\hline 7 & & & 10 & & & & $5 ?$ & & & & 40 & & 84 & & \\
\hline$C_{0}$ & & & & & & & 12 & & & & & & 10 & & \\
\hline
\end{tabular}

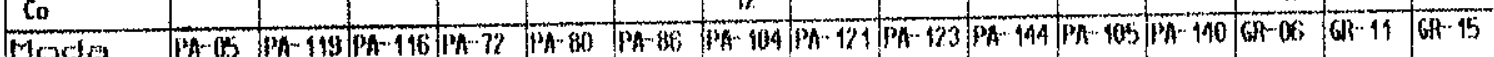

\begin{tabular}{|c|c|c|c|c|c|c|c|c|c|c|c|c|c|c|c|}
\hline Mostrat & $P^{2} A-15$ & +119 & $p h=1$ & & I & & & & & & & & & & \\
\hline Quartzo & 50 & 85 & & 55 & 50 & 56 & 30 & 50 & 75 & 42 & & & 5 & & \\
\hline Folcalino & & & & & 3 & 1 & $x$ & $x$ & & & & & & & \\
\hline Plagioclásio & 3 & & & & 2 & $?$ & & $x$ & & & & & & & \\
\hline Biotita & $?$ & & & & & & & 1 & & & & & & & \\
\hline Clorita & & & & & & 7 & 20 & $?$ & & & & & 35 & & \\
\hline lkordilenda & & & & & & & & & & & & & & & \\
\hline Soricita & 40 & 13 & & 45 & 40 & 37 & 17 & 45 & 21 & 50 & 85 & 86 & 5 & & \\
\hline Titanita & & & & & & & & & 1 & & & & & & \\
\hline Apatita & & & & & & & & & & & & & & & \\
\hline Epidoto & & & & & & & & & & & & & & & \\
\hline $2 i r c k$ & $x$ & $x$ & & & $x$ & & & & 1 & & & & & & \\
\hline Cor inkan & & & & & & & & & & & 1 & $?$ & & & \\
\hline Pargar ita & & & & & & & & & & & 1 & 1 & & & \\
\hline Oracos & 5 & 2 & & 5 & 5 & 3 & 3 & 2 & 7 & 8 & 13 & 11 & 15 & & \\
\hline
\end{tabular}

\section{LECEFDA:}

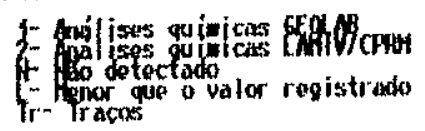




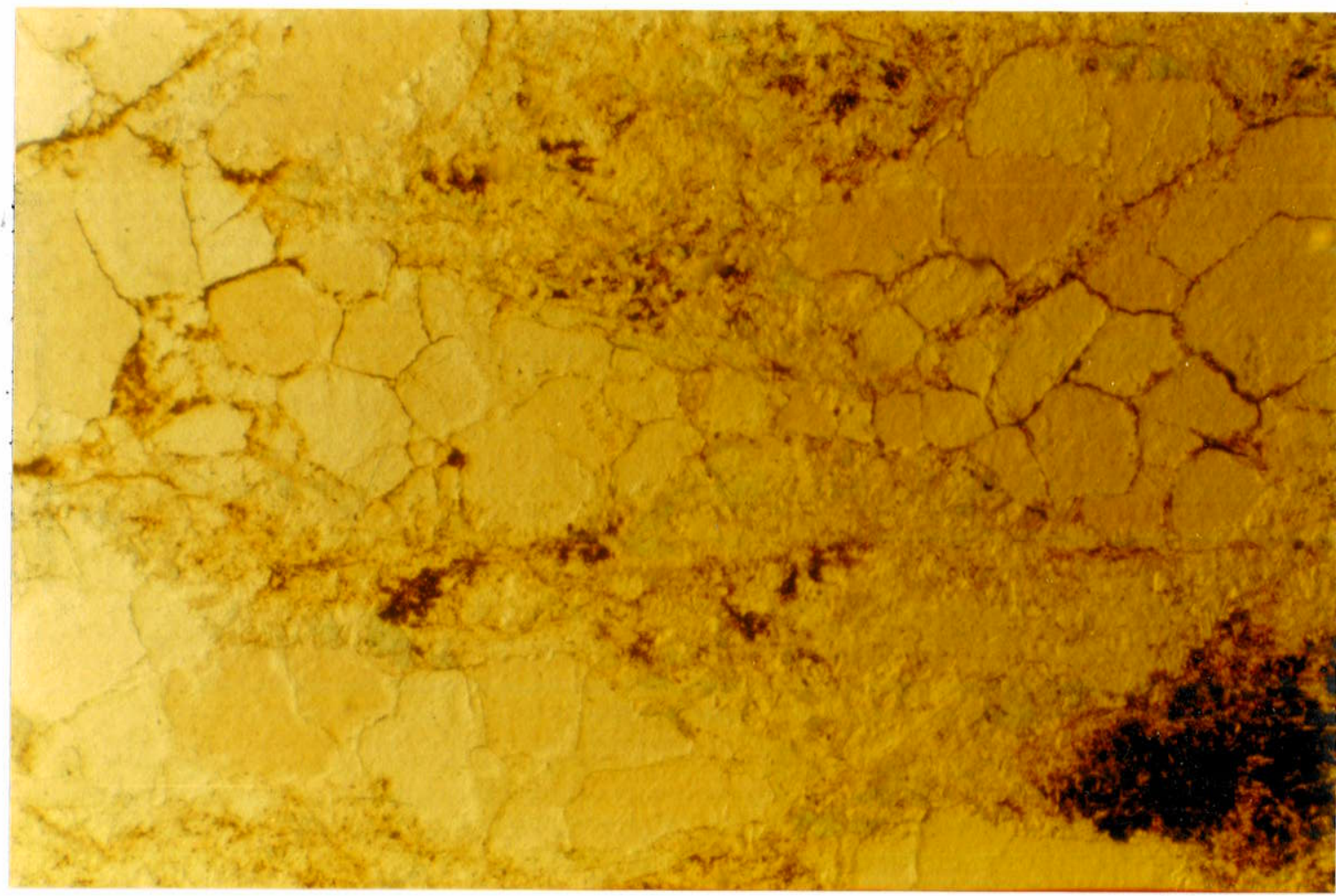

Microfoto 5: Amostra PA - 60, aumento 78.75x, NP. Quartzo milonito apresentando-se micro bandado com faixas de quartzo recristalizados em sub-grãos, na forma de ribbons e faixas sericíticas

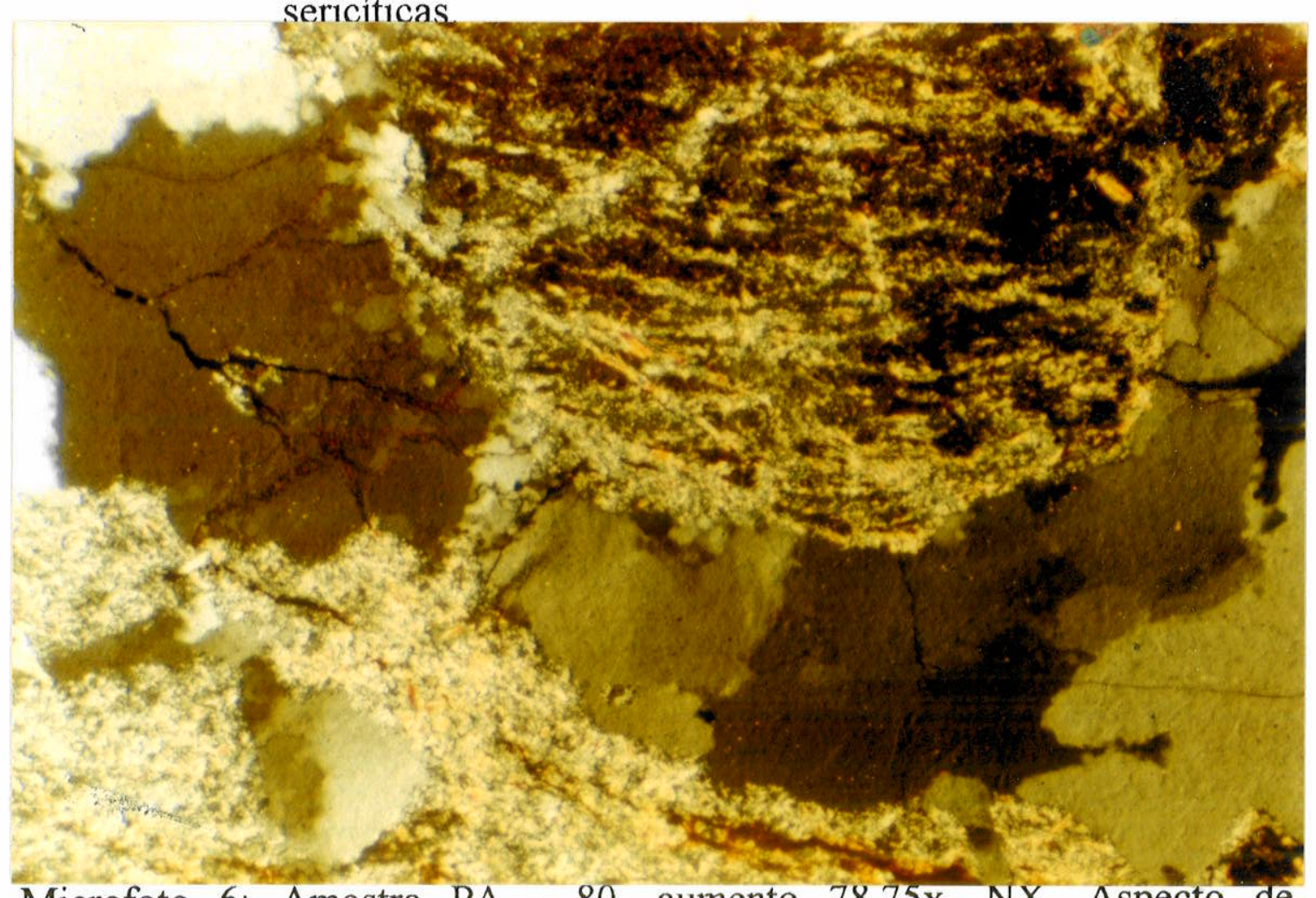

Microfoto 6: Amostra PA - 80, aumento 78.75x, NX. Aspecto de granito milonitizado com cristais reliquiares de feldspato se transformando em uma massa de sericita. 
Nas fraturas de cisalhamentos, vinculadas aos binários cisalhantes, é marcante o desenvolvimento de halos miloníticos, verificado principalmente nas cavas dos filões gerados em tais sistemas, caso dos filões do Paraíba, Manelão, Mineiro, Elvelcio, Geraldo, Olerindo, Melado, Sebastião, Grota do Pará, e outros.

\section{5 - Granitos Pré-Uatumã}

Individualizamos dentro desta unidade dois tipos de granitos intrusivos no embasamento, muito provavelmente correlacionáveis aos granitóides de idade Transamazônica de Macambira et al. (1990), ou seja: os granitos Tipo Juruena e Matupá. Manteve-se a denominação Granitos Indivisivos para agrupar variedades petrográficas com características e ambiências incompatíveis com as unidades graniticas já descritas na bibliografia.

A caracterização desses granitos foi feita principalmente com base em critérios petrográficos, metalogenéticos, e no estreito relacionamento desses granitos com os Granitóides Arqueanos, apesar de não terem sido observadas relações de contato diretas.

O Granito Tipo Juruena, com predomínio de biotita monzogranitos, apresentam muitas similaridades petrográficas e estruturais com o Granito Juruena, proposto por Silva et al. (1974) e Souza et al. (1980). Já o Granito Matupá, é eminentemente um granito transformado, tipo hidrotermalito, apresentando depósitos auríferos, com características muito similares às mineralizações tipo pórfiro, resultantes da intensa percolação de fluídos, tardi a pós-magmáticos, enriquecidos em $\mathrm{K}, \mathrm{Na}, \mathrm{CO}_{2}, \mathrm{~S}$ e $\mathrm{Au}$.

\subsection{1 - Granito Tipo Juruena}

Constituem corpos intrusivos de formas irregulares, com diâmetro da ordem de 3 a $5 \mathrm{Km}$, frequentemente circundados por gnaisses do Complexo Xingu e Granitóides Arqueanos, aflorando principalmente como matacões e blocos arredondados nos interflúvios e cabeceiras dos córregos Baixão Novo, Paulista e Cajá. Alguns contatos prováveis ocorrem ao longo de falhamentos, caso da falha de natureza indeterminada de direção $\mathrm{N} 35 \mathrm{E}$, delimitada no interflúvio entre os córregos do Zé Deco e Paulista, ao longo da qual se observa o alinhamento de pelo menos seis corpos mineralizados do tipo veio de quartzo. Alguns dados petroquímicos disponiveis para granitos do tipo Juruena estão relacionados na (Tabela 07).

Nos afloramentos observados, os litótipos pertencentes ao Granito Tipo Juruena apresentam-se com tonalidades acinzentadas, e localmente cinzarosadas, provavelmente quando afetados por fluidos hidrotermais, com neo-geração de feldspato potássico e sulfetos disseminados. 


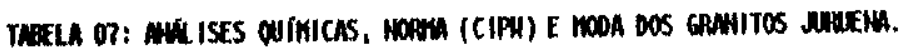

\begin{tabular}{|c|c|c|c|c|c|c|c|c|c|c|}
\hline 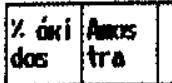 & $\begin{array}{r}P_{a-30} \\
2\end{array}$ & 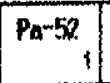 & $\begin{array}{r}P a-52 a \\
2\end{array}$ & $\mathrm{~Pa}-75$ & \begin{tabular}{r|}
$P_{0}-107 a$ \\
1
\end{tabular} & $\begin{array}{r}P a-107 \\
2\end{array}$ & $\begin{array}{r}\mathrm{Pa}-133 \\
2\end{array}$ & $\begin{array}{r}P a-157 \\
1\end{array}$ & $\begin{array}{r}P a-118 \\
2 \\
\end{array}$ & $\begin{array}{r}\mathrm{Pa}-135 \\
2\end{array}$ \\
\hline 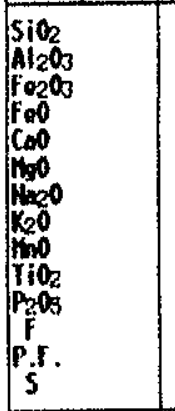 & \begin{tabular}{c|}
0.9 \\
14.7 \\
1.8 \\
0.8 \\
2.2 \\
1.2 \\
3.9 \\
3.8 \\
0.06 \\
0.31 \\
0.13
\end{tabular} & \begin{tabular}{|c|}
66.8 \\
13.8 \\
1.7 \\
2.4 \\
2.6 \\
2.0 \\
3.8 \\
4.6 \\
0.08 \\
0.48 \\
0.25 \\
0.13 \\
0.85 \\
0.007 \\
\end{tabular} & \begin{tabular}{c|}
57.9 \\
13.2 \\
3.3 \\
3.5 \\
5.8 \\
5.4 \\
3.5 \\
4.6 \\
0.49 \\
0.73 \\
0.42
\end{tabular} & $\begin{array}{l}71.8 \\
43.1 \\
0.77 \\
2.1 \\
1.5 \\
0.87 \\
3.3 \\
4.7 \\
0.09 \\
0.32 \\
0.12 \\
0.11 \\
0.81 \\
0.006\end{array}$ & \begin{tabular}{|c|}
8.8 \\
14.3 \\
1.0 \\
2.5 \\
2.0 \\
1.2 \\
3.4 \\
4.6 \\
10.11 \\
0.44 \\
0.20 \\
0.12 \\
0.85 \\
0.006
\end{tabular} & $\begin{array}{c}68.8 \\
14.2 \\
2.5 \\
0.8 \\
1.7 \\
1.6 \\
3.5 \\
4.4 \\
0.07 \\
8.58 \\
0.24\end{array}$ & $\begin{array}{c}68.8 \\
14.2 \\
2.2 \\
1.4 \\
2.5 \\
1.1 \\
3.8 \\
4.4 \\
0.06 \\
0.47 \\
0.23\end{array}$ & \begin{tabular}{|l|}
69.6 \\
14.7 \\
1.1 \\
1.9 \\
1.8 \\
1.3 \\
2.7 \\
4.8 \\
0.13 \\
0.42 \\
0.18 \\
0.079 \\
1.41 \\
0.005 \\
\end{tabular} & $\begin{array}{l}65.9 \\
16.1 \\
2.3 \\
1.2 . \\
2.8 \\
0.83 \\
1.6 \\
3.8 \\
0.05 \\
0.57 \\
0.88 \\
1.1 \\
0.03\end{array}$ & $\begin{array}{c}71.9 \\
12.8 \\
1.4 \\
0.45 \\
1.5 \\
0.33 \\
4.3 \\
5.8 \\
0.05 \\
0.1 \\
0.28 \\
1.2 \\
0.03 \\
\end{array}$ \\
\hline \multicolumn{11}{|l|}{ (pas) } \\
\hline 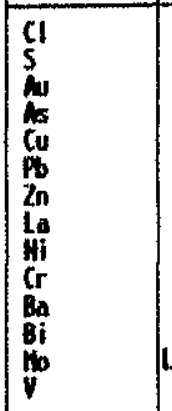 & $\begin{array}{c}0.06 \\
11 \\
28 \\
12 \\
41 \\
5 \\
11 \\
28 \\
84 \\
14 \\
2.0\end{array}$ & $\begin{array}{l}7 i \\
H\end{array}$ & $\begin{array}{c}0.05 \\
\text { in } \\
27 \\
8 \\
29 \\
8 \\
35 \\
420 \\
285 \\
4 \\
4\end{array}$ & $\begin{array}{r}26 \\
N\end{array}$ & $\begin{array}{l}65 \\
H\end{array}$ & $\begin{array}{c}0.05 \\
i \\
46 \\
10 \\
52 \\
7 \\
44 \\
28 \\
44 \\
4 \\
2.0 \\
28\end{array}$ & $\begin{array}{l}0.03 \\
\text { in } \\
26 \\
16 \\
48 \\
8 \\
19 \\
28 \\
48 \\
{ }^{4} \\
20 \\
32\end{array}$ & $\begin{array}{r}29 \\
H\end{array}$ & $\begin{array}{c}H \\
8 \\
8 \\
50 \\
4 \\
10 \\
80 \\
4 \\
2.0 \\
32\end{array}$ & $\begin{array}{r}N \\
4 \\
42 \\
10 \\
4 \\
4 \\
8 \\
46 \\
4 \\
4 \\
16\end{array}$ \\
\hline $\begin{array}{l}\text { Morma } \\
\text { Cipw }\end{array}$ & $P a-30$ & Pa-5? & $P a-52 a$ & $P a-75$ & $\mathrm{~Pa}-407 \mathrm{a}$ & $P_{a}-107$ & $P o-133$ & $P a-157$ & $\mathrm{~Pa}-118$ & $P a-135$ \\
\hline puartxo & 26.44 & 93.42 & 3.56 & 28.55 & 24.34 & 26.67 & 24.27 & 29.83 & 20.25 & 24.46 \\
\hline Ortoclasio 2 & 23.31 & 27.60 & 27.59 & 28.15 & 27.56 & 26.42 & 26.32 & 73.91 & 21.53 & 33.53 \\
\hline Albita & 33.37 & 32.44 & 30.05 & 28.22 & 28.9 & 30.183 & 32.54 & 23.10 & 39.38 & 33.44 \\
\hline Anortita & 10.20 & 7.24 & 6.83 & 6.88 & 8.88 & 6.98 & 8.80 & 8.62 & 8.24 & - \\
\hline Cor Inden & 0.37 & - & - & 0.13 & 0.57 & 1.18 & - & 1.73 & 1.67 & $=$ \\
\hline Hiporstenio: & 3.02 & 5.75 & 9.13 & 5.00 & 6.32 & 4.05 & 1.8 & 5.47 & 2.09 & - \\
\hline Diopsidio & - & 3.50 & 15.02 & - & - & - & 1.74 & - & - & 1.85 \\
\hline Regontita & 4.86 & 2.50 & 4.85 & 1.13 & 1.47 & 1.65 & 2.55 & 4.62 & 2.41 & 1.29 \\
\hline Olivina & - & - & - & - & $=$ & - & + & - & . & - \\
\hline Ilemita & 0.60 & 0.93 & 1.41 & 0.82 & 0.85 & 1.00 & 0.81 & 0.21 & 1.10 & 0.19 \\
\hline toatipa & 0.30 & 0.60 & 4.04 & 0.29 & 0.48 & $0.5 \%$ & 0.55 & 0.43 & 2.11 & 0.70 \\
\hline Cranita & 0.01 & $-\cdots$ & 0.03 & 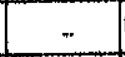 & 0.04 & $\cdots$ & - & - & - & - \\
\hline Fibtelin & - & 0.7 & - & 0.68 & 0.14 & - & - & 0.10 & - & - \\
\hline Falita & - & 0.04 & - & \pm & 0.11 & $=$ & - & - & - & $=$ \\
\hline Acoits & - & - & - & - & $\therefore$ & - & - & - & - & 8.53 \\
\hline Holustonita & - & - & ..- & - & .. & - & - & - & $\ldots$ & 1.37 \\
\hline
\end{tabular}




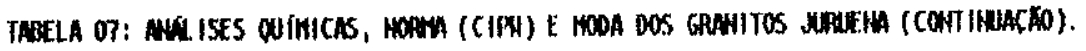

\begin{tabular}{|c|c|c|c|c|c|c|c|c|c|c|c|c|c|}
\hline $\begin{array}{l}\text { Moda } \\
\text { ost imada }\end{array}$ & Pa & $\begin{array}{l}\mathrm{Pa}_{\mathrm{a}}-30 \\
\mathrm{agr}\end{array}$ & Paris? & $\mathrm{Pa}-52 \mathrm{a}$ & 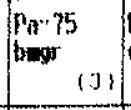 & Pa 107 & 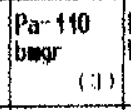 & piw 111 & $\mathrm{Pa}_{\mathrm{a}}+18$ & $\begin{array}{l}\mathrm{Pa}+133 \\
\text { baws }\end{array}$ & $\left\{\begin{array}{l}P a-435 \\
\text { warh }\end{array}\right.$ & $\left|\begin{array}{r}P_{a-157} \\
\text { begre } \\
131\end{array}\right|$ & $\begin{array}{c}p_{a}-4070 \\
b a r 5 \\
131 \\
\end{array}$ \\
\hline Quartro & 28.0 & 30.0 & 38.0 & & 30.0 & 28.0 & 27.0 & 40.0 & 30.0 & 30.0 & 30.0 & 27.0 & 32 \\
\hline F. Alcalino & 37.0 & 25.0 & 30.0 & & 30.0 & 25.0 & 25.0 & 35.0 & 25.0 & 32.0 & 27.0 & 25.0 & 27 \\
\hline Planioxlísio & 23.0 & 34.0 & 35.0 & & 32.0 & 35.0 & 37.0 & 75.0 & 35.0 & 28.0 & 37.0 & 35.0 & 37 \\
\hline Biotita & 5.0 & 2.0 & 3.0 & & 5.0 & 5.0 & 7.0 & 5.0 & 5.0 & 5.0 & 3.0 & 5.0 & 5.0 \\
\hline Clorita & 3.0 & 2.0 & 2.0 & & & $x$ & & 1 & 2.0 & $x$ & & & \\
\hline flornblonds & $x$ & & $x$ & & & $x$ & & & & & $x$ & & \\
\hline Sor icita & 3.0 & 2.0 & $k$ & & & 2 & & $?$ & & 2.0 & 1.0 & & \\
\hline fitanita & & $x$ & $x$ & & & 4 & & $x$ & 2.0 & 1.0 & $x$ & & \\
\hline Apatita & & $x$ & $x$ & & & & & $x$ & & $x$ & $x$ & & \\
\hline tipldato & $x$ & 2.0 & $x$ & & & 7 & & 2 & & 7.0 & 3.0 & & \\
\hline Ziresko & & $x$ & $x$ & & & & & & & & $x$ & & \\
\hline Carbonato & & & $x$ & & & & & & & & $x$ & & \\
\hline Opacos & $x$ & $x$ & $x$ & & & $x$ & & $x$ & 1.0 & $x$ & 1.0 & & \\
\hline
\end{tabular}

LEGENDA:

 \\ 2. Anál ise quíuicas - L.ANINCPQH \\ 3. Hodo abtida por color imotr is \\ 4. For iquecimonto potassio \\ $X$. Hiner al com moda ( $\%$ \\ L. Kenor one o valor registrado \\ N. Wo dotectado
}

Osai Pafza - Miparenólito de comoxicho dior itica
begr - biotita anzoxponito
mrh - monzogranito rom hornohlenda
bumgrh - biotita mavzodranito al hornob tondo
oplosir - ppidoto mazouranito

di . diarito 
Estas rochas apresentam grande homogeneidade composicional, com as variedades petrográficas representadas principalmente por biotita monzogranitos e biotita granodioritos, estes de ocorrência pontual. São rochas leucrocráticas, isótropas, equigranulares de granulação média, e/ou porfiríticas, com cristais centimétricos de plagioclásio zonados, que geralmente possuem os núcleos mais cálcicos saussuritizados (Microfoto 7).

Os termos porfiríticos, aflorantes principalmente na cabeceira do córrego Baixão Novo (pontos PA - 52 e 135) apresentam uma matriz de granulometria fina a média de composição monzogranítica, com variedades do tipo hornblenda granodiorito. Nessa fácies mais porfirítica é comum a presença de enclaves decimétricos, alongados, de metadioritos e rochas metabásicas (Foto 07).

A mineralogia essencial está representada por plagioclásio (oligoclásio e andesina), feldspato potássico (pertita, ortoclásio e microclínio pertítico), quartzo e biotita. Como acessórios, ocorrem biotita, hornblenda, titanita, apatita e zircão.

A biotita possui coloração parda a verde, ocorre frequentemente alterada para clorita e associada a hornblenda (verde); epidoto em grãos bem individualizados também ocorrem associado a biotita e a hornblenda. A titanita, por vezes alterada para leucoxênio, ocorre na forma de cristais idiomórficos ou como inclusões nos planos de clivagem da hornblenda e biotita, e ainda associada a magnetita.

O feldspato potássico mais frequente é o microclíneo pertítico, em fenocristais sub euédricos de 5 a $10 \mathrm{~mm}$, ou com formas anedrais, com inclusões zonadas de quartzo e por vezes englobando cristais de plagioclásio, biotita e epidoto; caso das amostras PA - 29/111/118/133/135/174/178. A presença de fenocristais de microclínio pertítico com bordas fraturadas, sugere que o mesmo pode estar associado a uma fase de reativação tectônica.

A deformação está expressa principalmente nos grãos de quartzo recristalizados, com sub-grãos alongados e extinção ondulante, no arqueamento das geminações dos plagioclásios e clivagens das biotitas, e por palhetas de biotita e feldspatos com as bordas fraturadas. A deformação está associada, provavelmente, aos estágios evolutivos finais ou mesmo a reativações das mega estruturas de cisalhamento que afetam os terrenos Arqueanos.

São marcantes nestas rochas os processos hidrotermais do tipo sericitização e cloritização, associados à alteração dos plagioclásios e biotitas.

No diagrama QAP (Figura 16), estas rochas posicionam-se no campo dos monzogranitos, correspondendo em parte à série cálcio-alcalina granodiorítica (médio K) de Lameyre e Bowden (1982).

A moda estimada, obtida em função dos dados da norma (Tabela 07) conforme diagrama QAP, de Le Maitre (1989), apresentado na Figura 17, posiciona os Granitos do tipo Juruena no campo dos monzogranitos e granodioritos. 


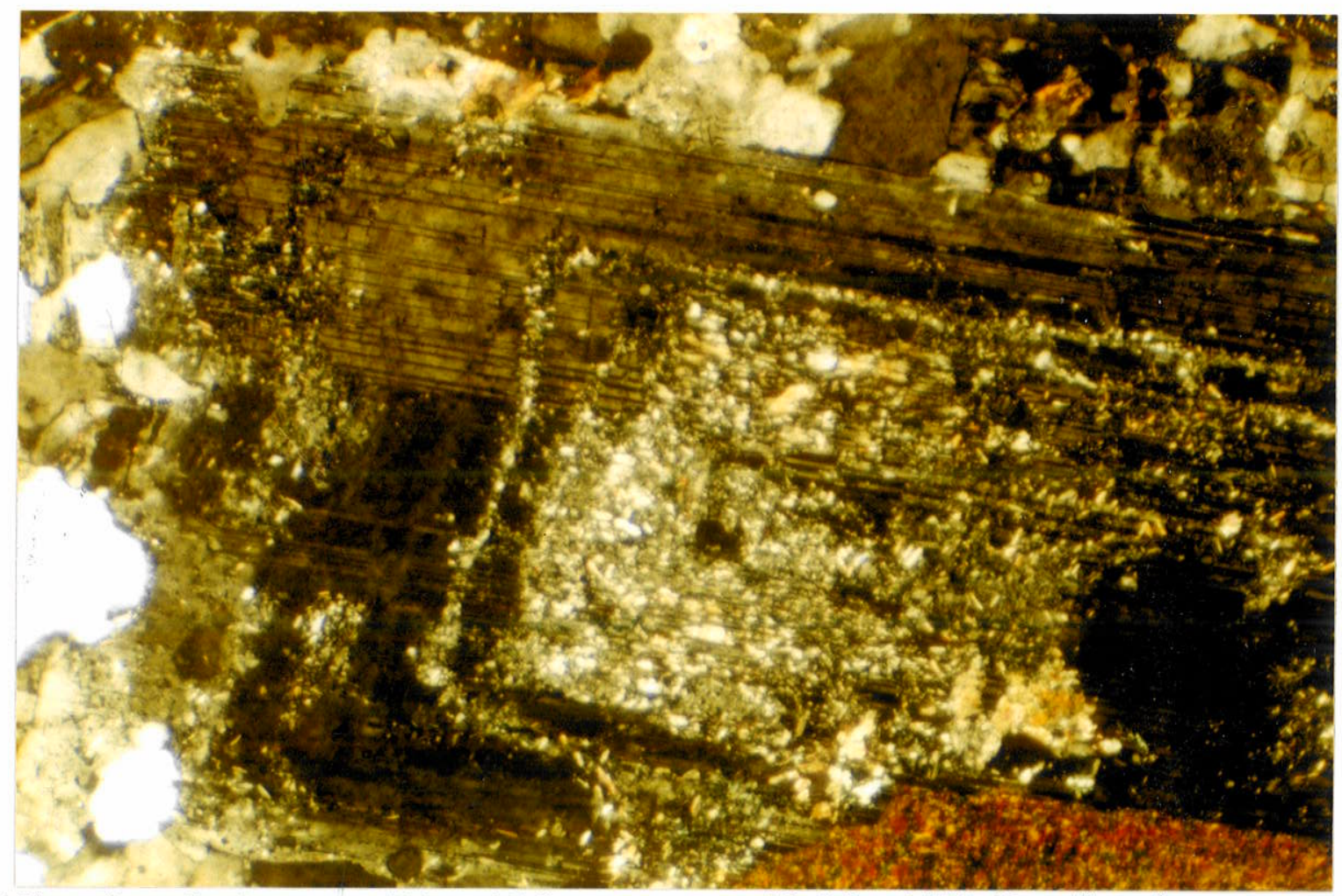

Microfoto 7: Amostra PA - 135a, aumento 78.75x, NX. Detalhe de uma rocha do tipo biotita granodiorito, com plagioclásio zonado apresentado núcleo mais cálcico saussuritizado.

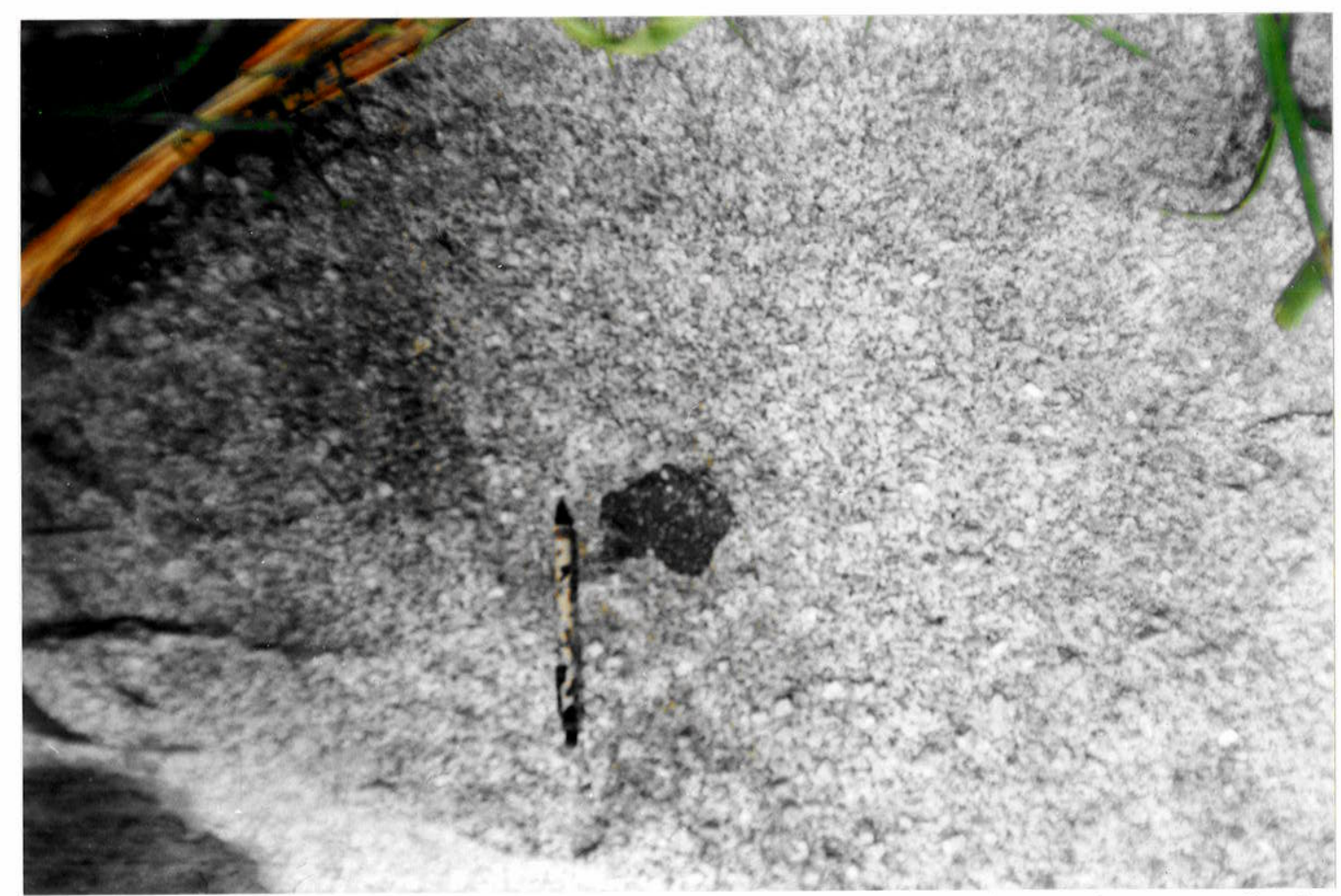

Foto 7: Amostra PA - 118. Granito Tipo Juruena, com enclaves de meta dioritos. 


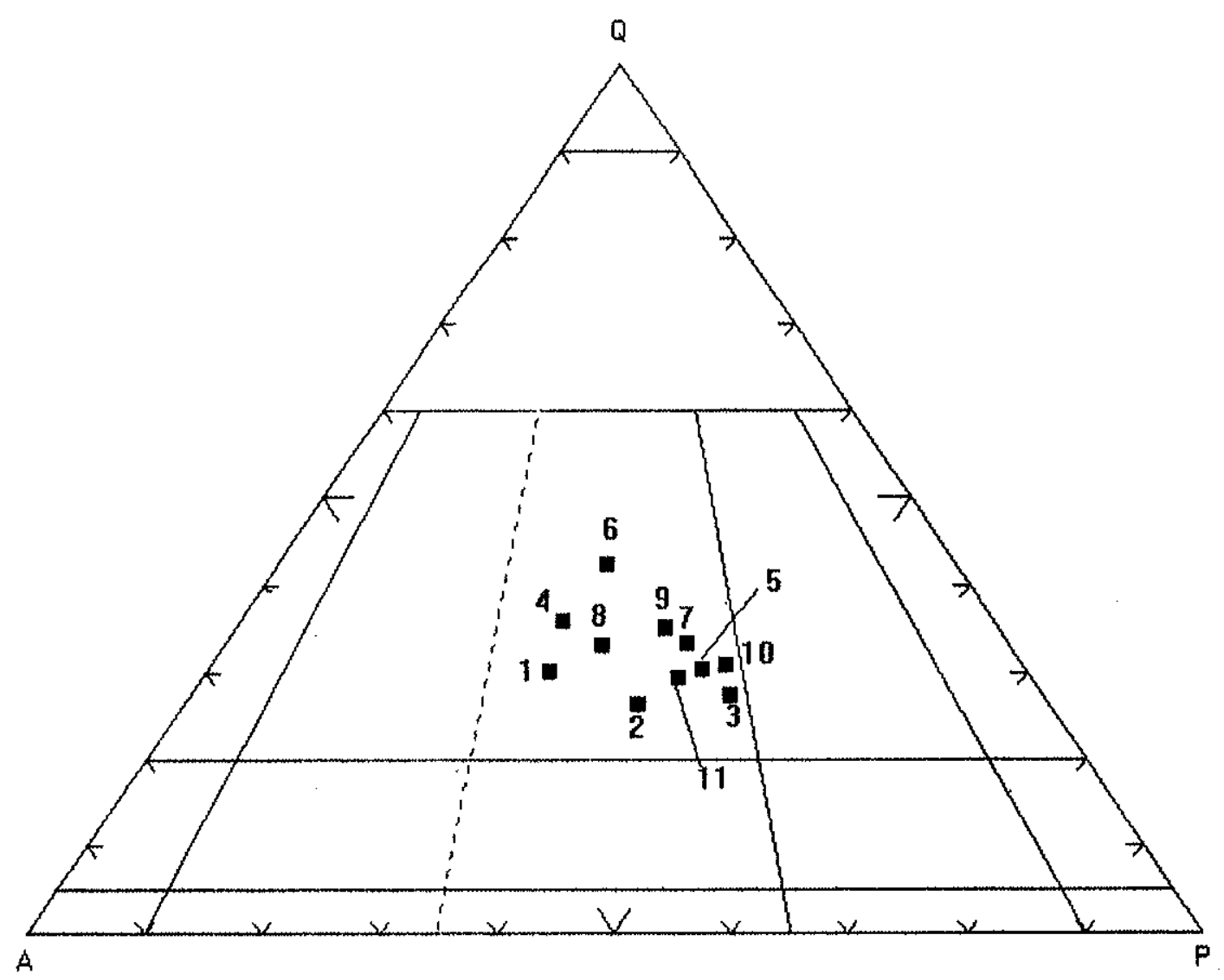

Fig. 16: Composição modal dos Granitos Juruena, diagrama QAP, de Streickeisen (1976)

1 PA06 Biotita Monzo Granito $\mathrm{c} /$ Hornblenda

2. PA30 Monzogranito

3 PA52 Monzogranito Porfiritico $\mathrm{c} /$ Hornblenda

4 PA75 Biotita Monzogranito Porfiritico

5 PA110 Biotita Monzogranito

6 PA111 Biotita Monzogranito

7 PA118 Biotita Monzogranito Porfirítico

8 PA133 Biotita Monzogranito

9 PA135 Monzogranito $\mathrm{c} /$ Hornblenda

10 PA107 Epídoto Monzogranito

11 PA157 Biotita Monzogranito Porfiritico 


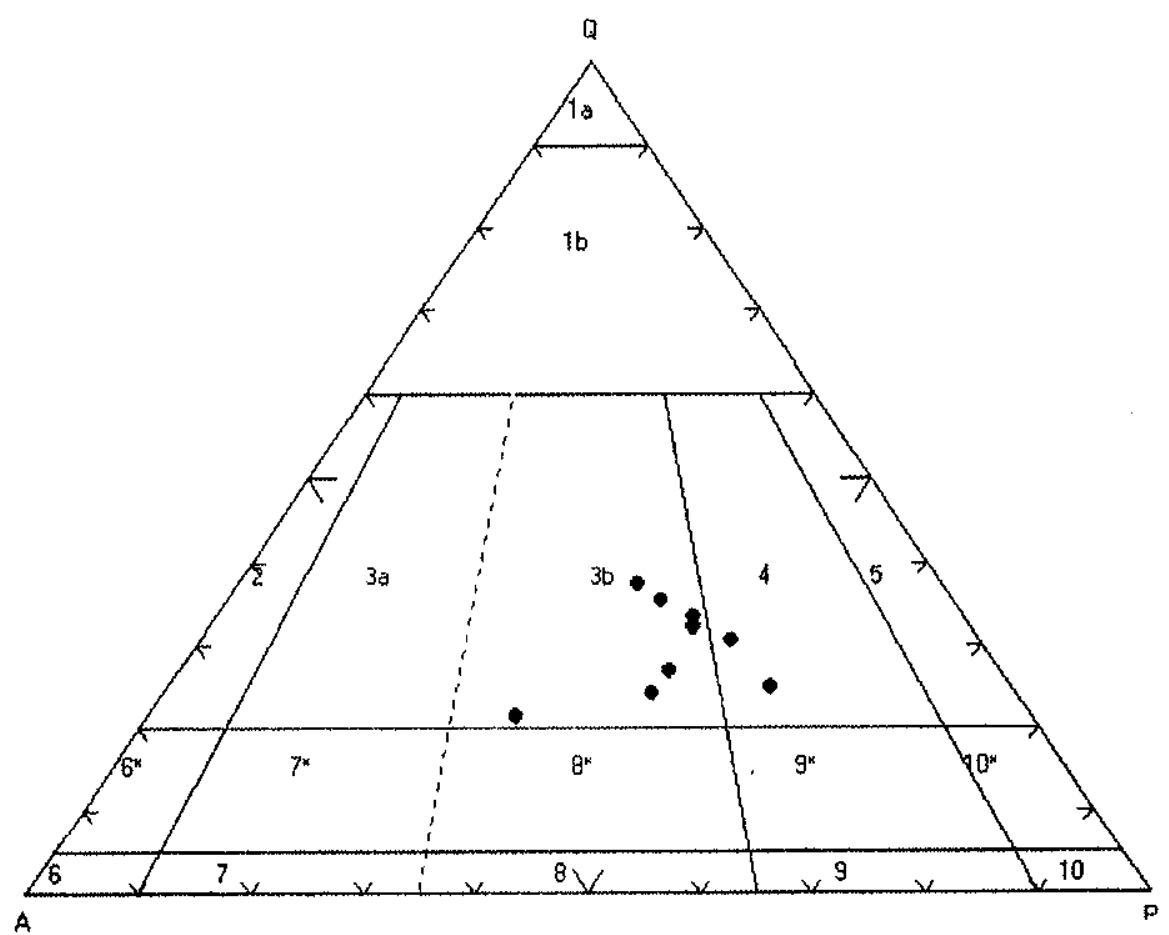

Fig. 17. Composição modal Granito Juruena. Le Maitre (1989).

No diagrama de Irvine \& Baragar (1971), (Figura 18), $\mathrm{FeO} / \mathrm{MgO} / \mathrm{Na}_{2} \mathrm{O}+\mathrm{K}_{2} \mathrm{O}$, estas rochas apresentam nítido trend cálcio-alcalino, com $\mathrm{Si}_{2} \mathrm{O}$ entre 66 a $73 \%, \mathrm{Na}_{2} \mathrm{O}+\mathrm{K}_{2} \mathrm{O}$ entre 7,5 a $9,9 \%, \mathrm{FeO}$ entre 0,8 a $2,5 \%, \mathrm{FeO}+$ $\mathrm{Fe}_{2} \mathrm{O}_{3}$ entre 1,85 a $4,1 \%$ e $\mathrm{MgO}$ entre 0,33 a $2,0 \%$.

São peraluminosos a metaluminosos, segundo critérios de Shand (1951; in Gastal, 1988), com índice de aluminosidade $(\mathrm{A} / \mathrm{CNK})<1$; parâmetros estes compativeis com os obtidos a partir dos dados plotados no diagrama de Maniar \& Piccoli (1989) (Figura 19).

Com relação ao óxido de titânio, os teores situam-se entre 0,1 a $0,57 \%$, apresentando uma variação inversamente proporcional ao teor de sílica (Figura 20). Observamse ainda que os termos mais diferenciados, com razão $\mathrm{K}_{2} \mathrm{O} / \mathrm{Na}_{2} 0$, moderada a alta $(1,21$ a 1,77$)$, estão relativamente enriquecidos em $\mathrm{SiO}_{2}$ e empobrecidos em $\mathrm{TiO}_{2}$ e $\mathrm{MgO}$ (Figura 20).

\subsection{2 - Granito Matupá}

A individualização desse tipo de associação granítica na área de pesquisa, mesmo considerando os poucos dados disponíveis, deve-se principalmente à intensidade das transformações hidrotermais verificadas em determinados sub-ambientes, dentro de um maciço rochoso de composição primária, mui provavelmente monzogranítica a granodiorítica, através de fluídos, com notória afinidade aurífera. As tranformações observadas são similares às descritas no maciço granítico Cigano, com idade de $1731 \pm 28 \mathrm{Ma}$., por Gonçalves et. al. (1988), 


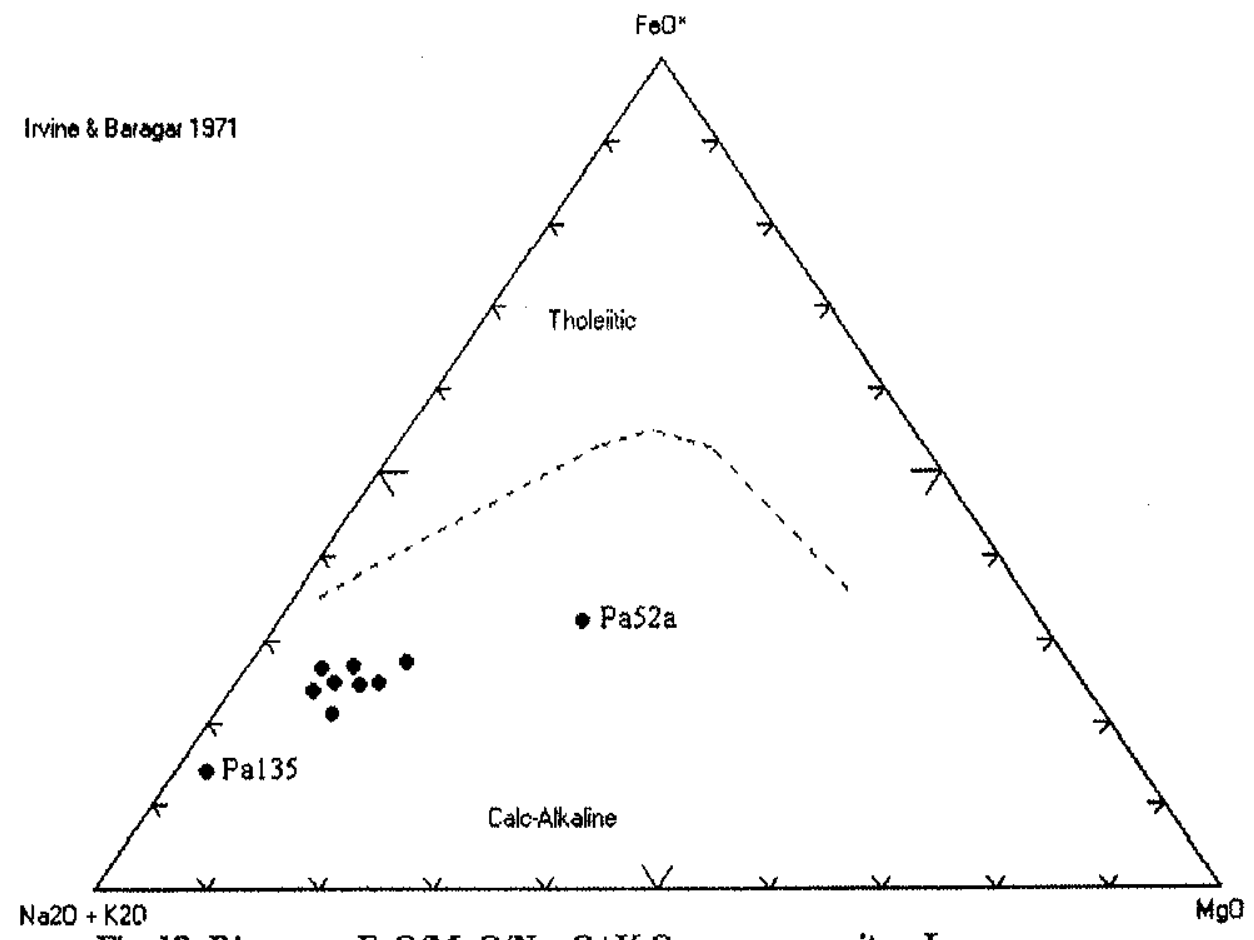

Fig. 18. Diagrama $\mathrm{Fe} \mathrm{O} / \mathrm{MgO} / \mathrm{NagO}+\mathrm{K} \mathrm{O}$ para os granitos Juruena

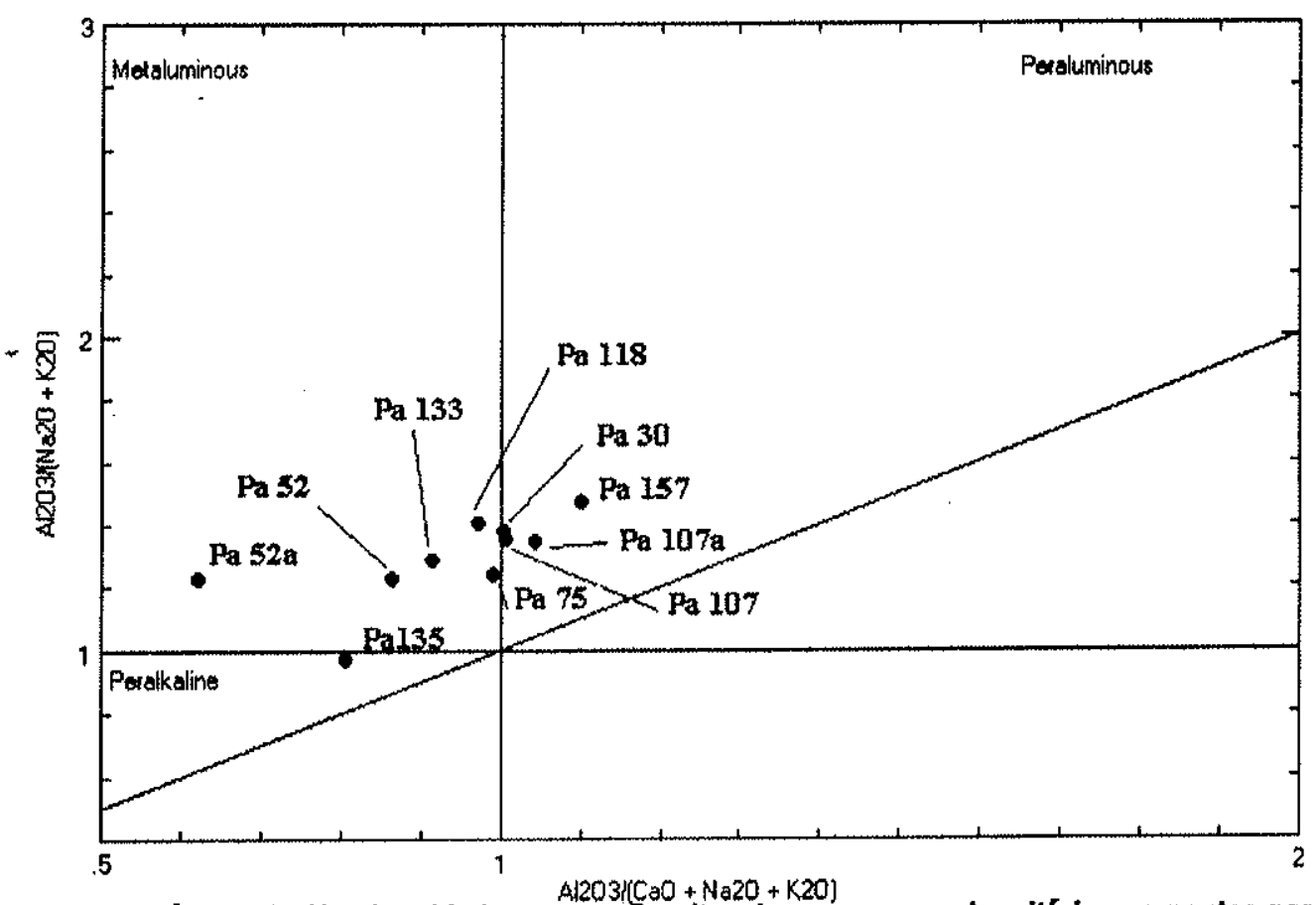

Fig. 19. índice de Aluminosidade para os Granitos Juruena, segundo criterios propostos por Maniar e Piccoll (1 989). 


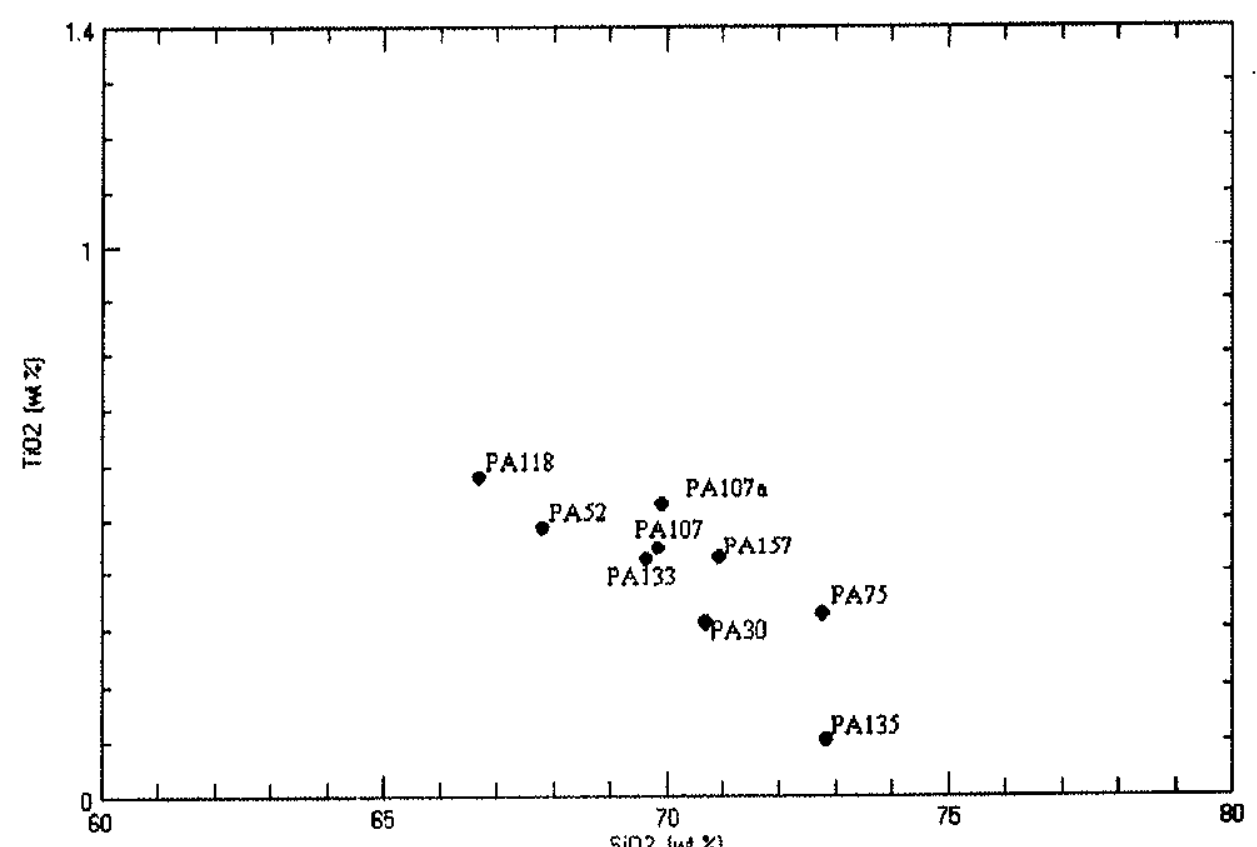

Fig. 20 Diagrama $\mathrm{SiO}_{2} \times \mathrm{TiO}_{2} \mathrm{Granito} \mathrm{Jupuena,} \mathrm{seguñdo} \mathrm{critérios} \mathrm{propostos} \mathrm{por} \mathrm{Maniar} \mathrm{e}$ Piccoll (1989).

Os corpos mapeados como Granito Matupá tem formas irregulares, e ocorrem principalmente em uma faixa alongada segundo o trend NW-SE, nas imediações da BR-080, onde se situam os principais garimpos, próximo à cidade de Matupá. Localmente, destacam-se sobre a superfície arrasada da região, como pequenas serras, alongadas segundo a direção N50-70E, com eixo maior da ordem de $500 \mathrm{mts}$. Por vezes ocorrem na forma de cristas, produzidas pelo balizamento de diques de diabásio, vulcânicas ácidas e microgranitos (Figura 21 e Foto 8), que sobressaem como relevos residuais.

Os Granitos Matupá são leucocráticos, de natureza isótropa, sem anfibólio, sem enclaves e com as porções mais hidrotermalizadas apresentando cores com tonalidades avemelhadas e/ou esverdeadas.

Em termos petrográficos é possivel verificar, nas rochas plotadas no diagrama QAP (Figura 22), a significativa influência dos processos de transformação tardi-a pós-magmáticos, superimpostos ao maciço. Os dados evidenciam que, as rochas menos afetadas (primárias) estão representadas principalmente por biotita granodioritos, que transformam-se em monzogranitos, a partir da interação com os fluidos, com significativa modificação no quimismo. Alguns dados petroquímicos estão relacionados na Tabela 08. Os biotita granodioritos (amostras MP-06 e MP-SR-03a) são rochas de coloração cinza-claro a róseo, textura hipidiomórfica equigranular, média a porfirítica, constituidas por plagioclásios (oligoclásio-andesina) zonados, subidiomórficos, e quartzo intersticial, com evidências de recristalização dinâmica incipiente. $O$ feldspato potássico é o microclínio pertítico, observado na matriz e principalmente como mega cristais $(0,3$ a $1 \mathrm{~cm}$ ), com inclusões milimétricas de plagioclásio e sericita. A biotita é o máfico principal, frequentemente alterando-se para clorita, ambos com palhetas quebradas e deformadas associados a titanita, epidoto e muscovita (Microfoto 8). 


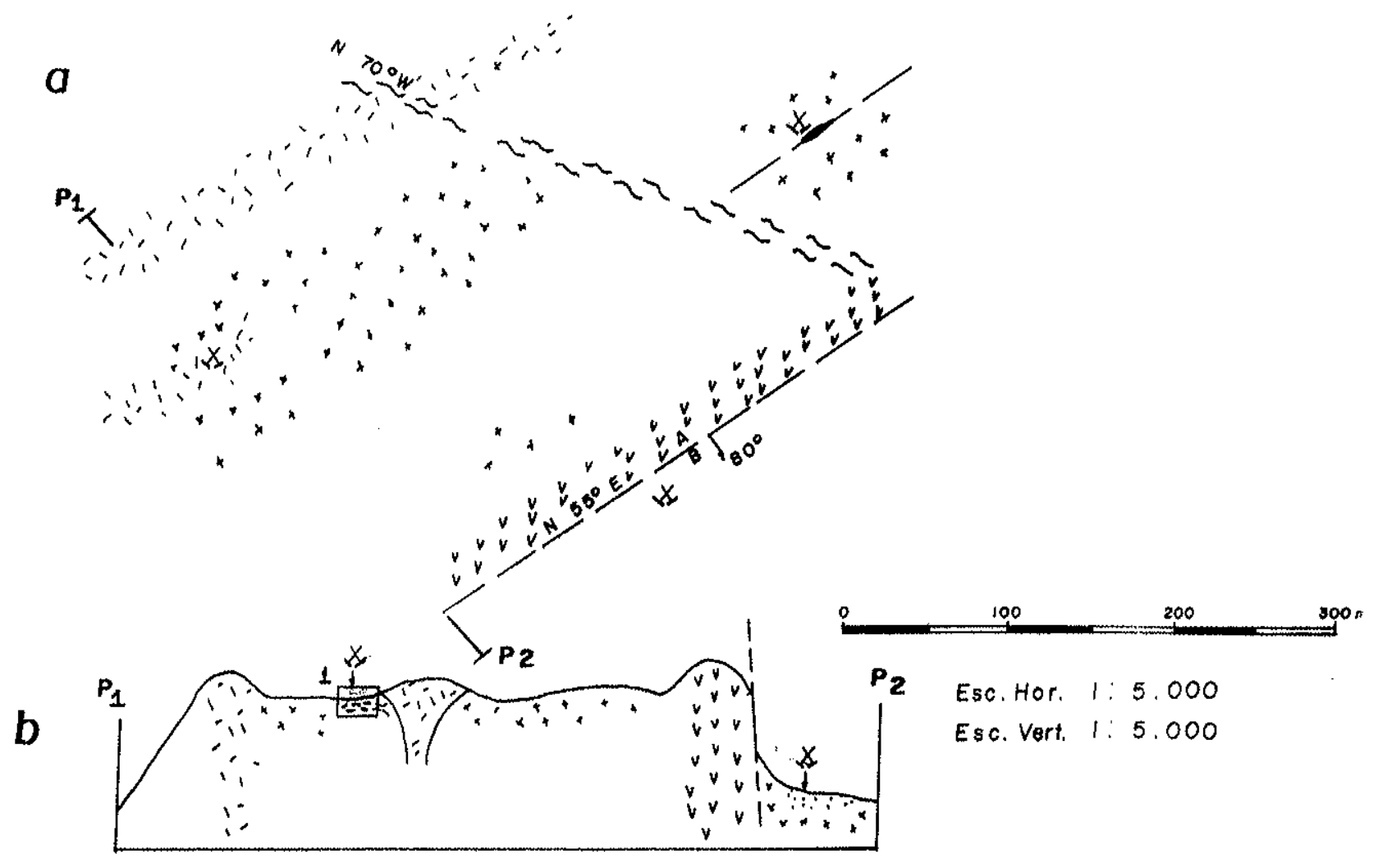

1. DETALHE EM SECCÃO ESQUEMA'TICA

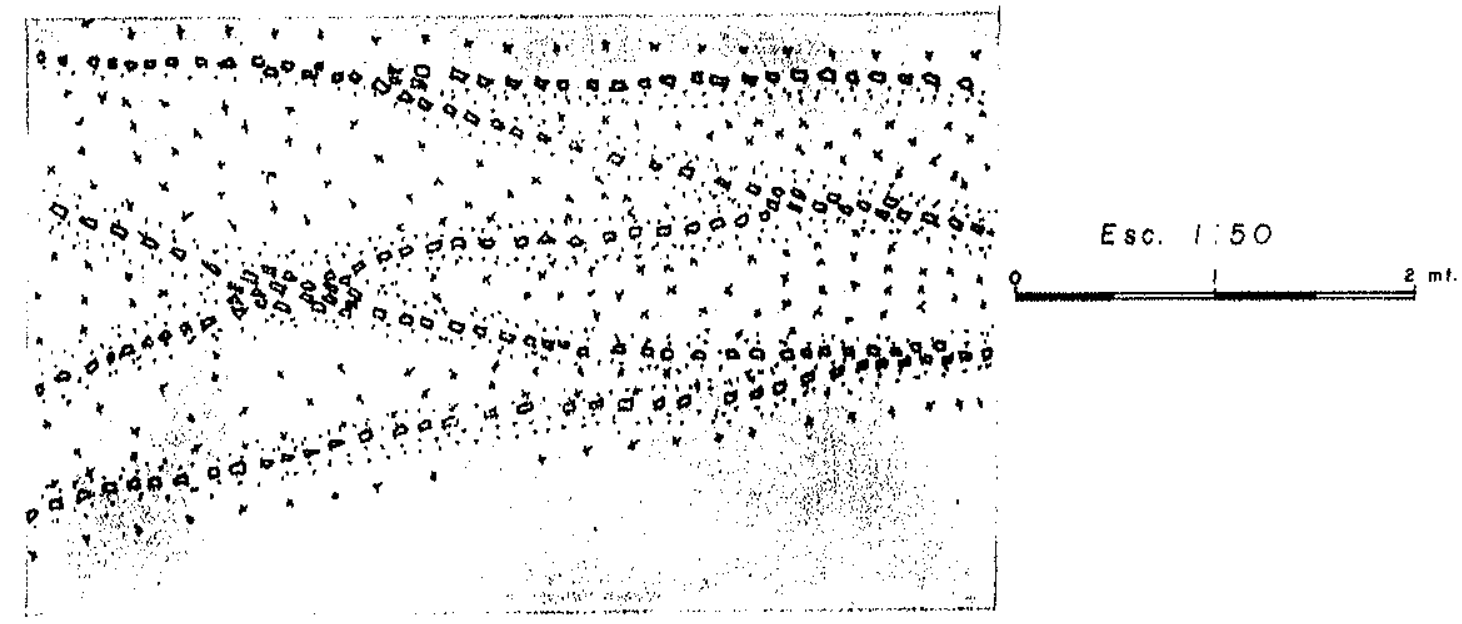

L E E $\quad G \quad E \quad N \quad D \quad A$

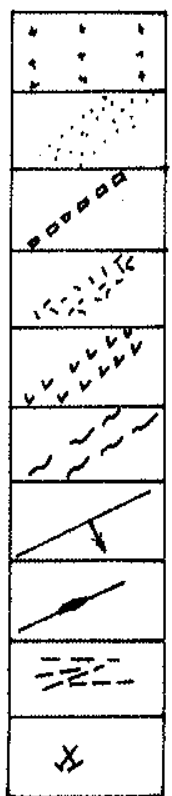

Monzo oranitos ogranodlorltos, oinzo overmalhados, portiriticos, Granito Motupo.

oronito hidrotermallzodo porticltlco moclao com intenso enriquecimento

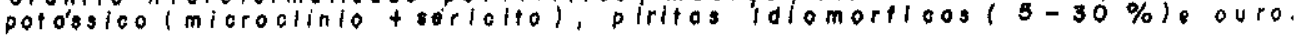

Rooho colprogáo overmethodo oom mopo oristals centlmetricos de microolim nio bolsos de pirita. mineratizodo com ouro.

Vuloanigo ocoldo de colorago roseo.

Diques de diaboslos.

zonos de cataciosedis oreta.

Folno normol com oalmento

velo de quortzo ourlfero

Froturas de ollvio

Figura-21

Oorimpo obandonodo

Planta (a) enseção Esquemolica (b) do Garim po de Serrinho-Matupó

(C) Frento Trevison 

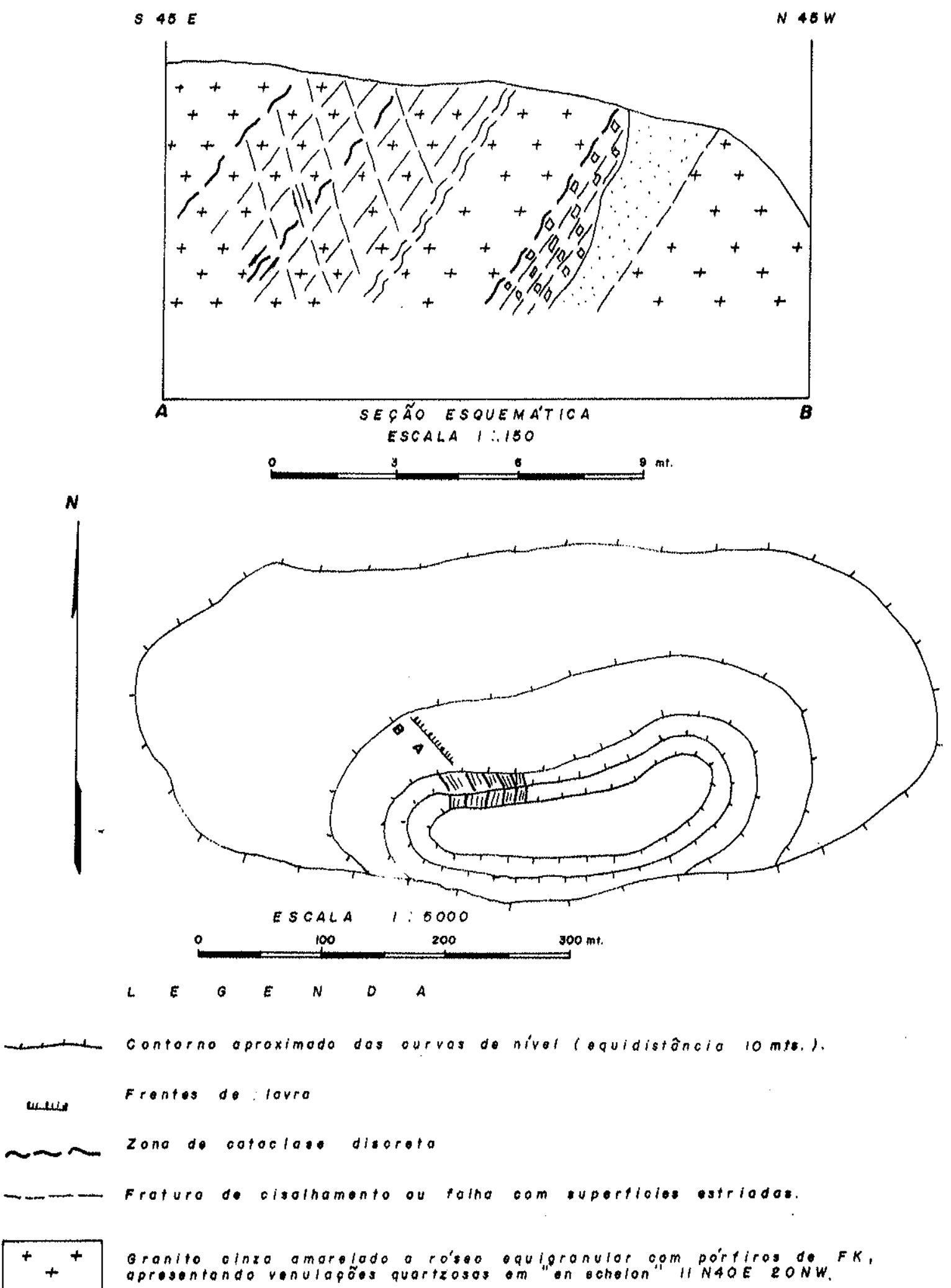

Contorno aproximodo dos ourvas do nivel (equidistôncio $10 \mathrm{mts}, 1$.

\section{Frentes do : lovro}

Zono de cotoctaos disoreto

Froturo de cisolhamento ou foltho com eupertiolos estriodos

Granito olnza amorolodo o roseo oquipranular com pórtiras do $F K$, apresontando venulapós quartzosos om "on ocholon" IINAOE $2 O N W$.

oranito cinzo osverdoado hidrotermalizodo, mactgo pórfirltico. 


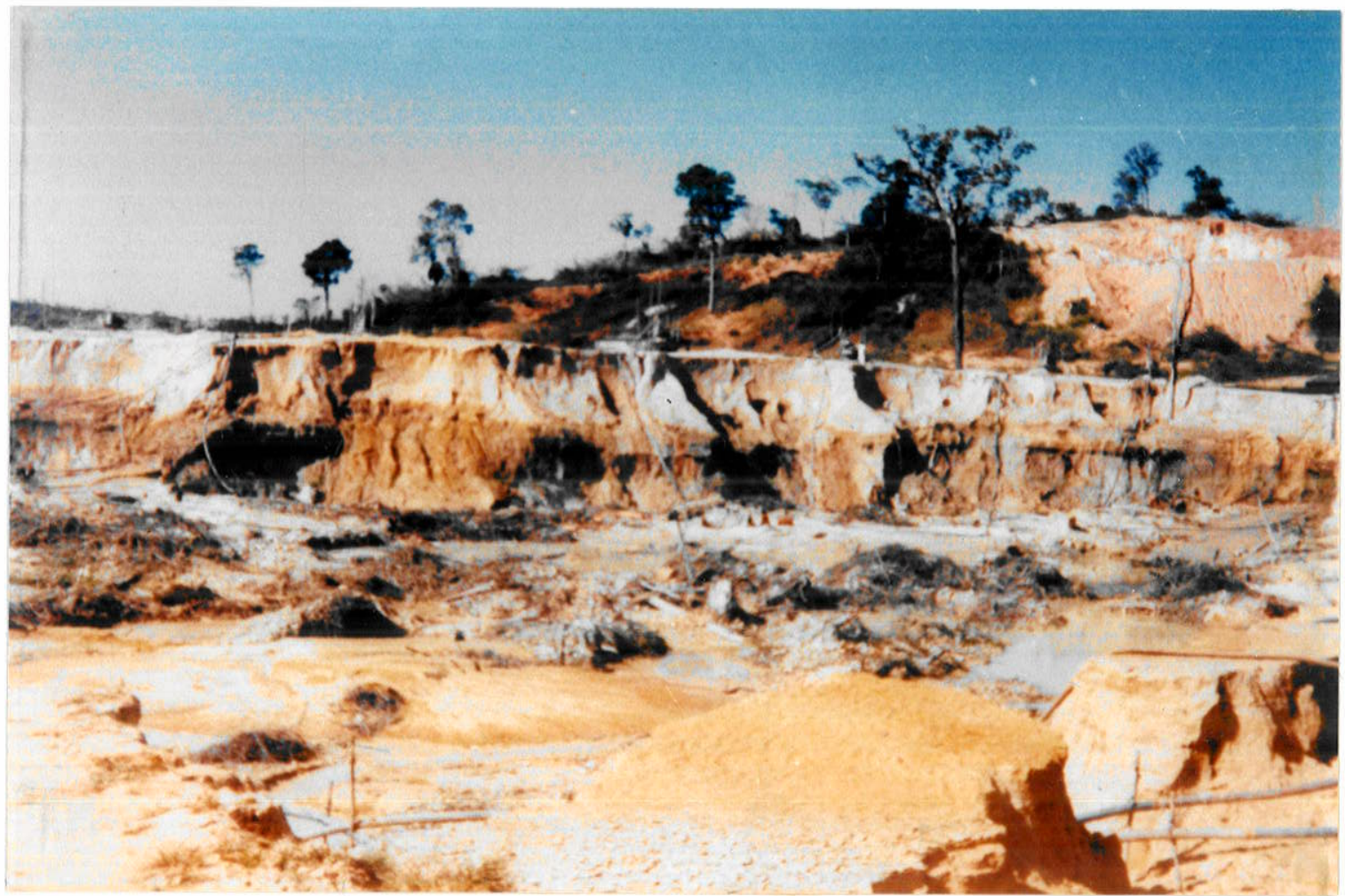

Foto 8: Amostra MP - 10/11/12. Aspecto das cristas garimpadas no contexto do Granito Matupá. Garimpo da Serrinha.

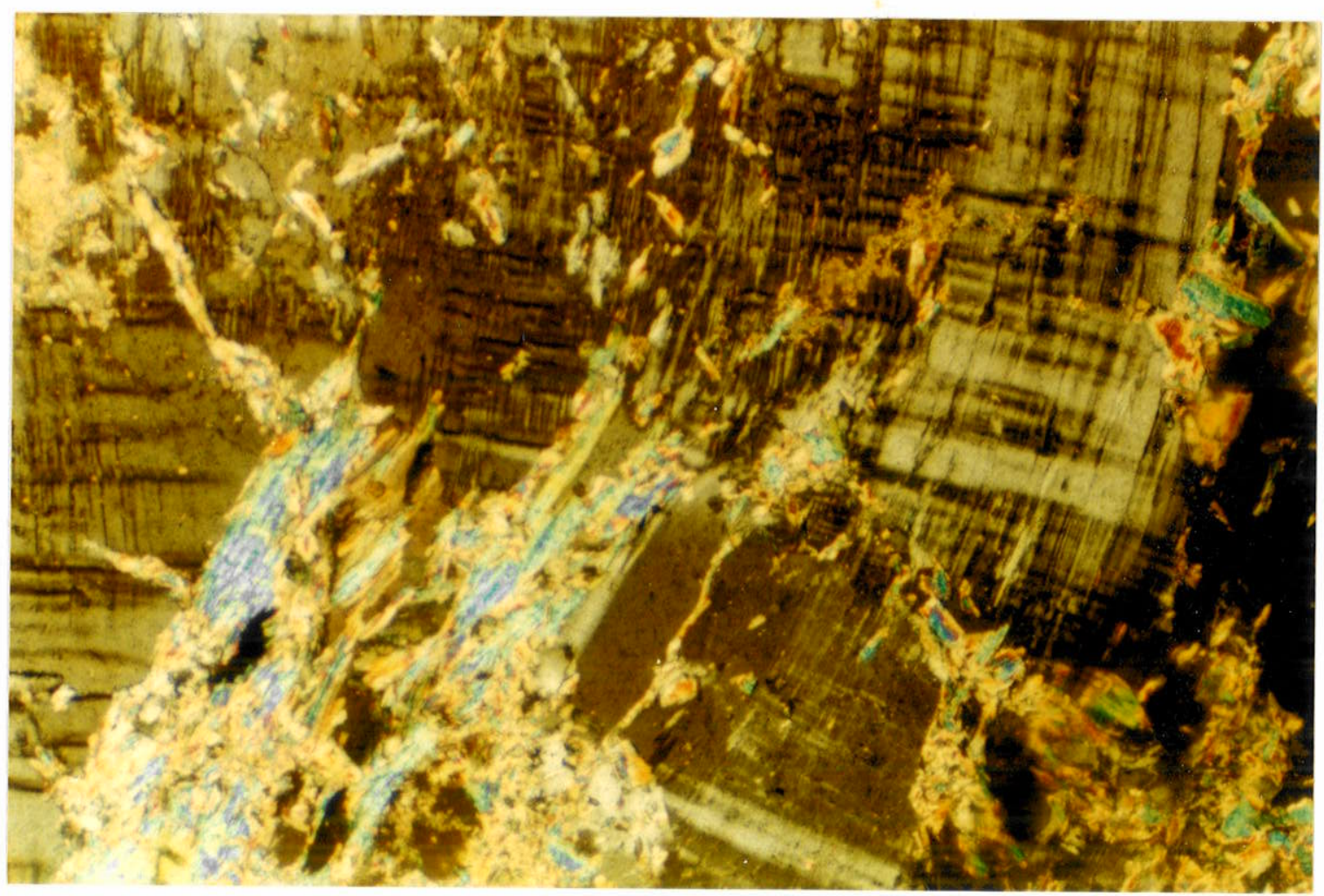

Microfoto 8: Amostra MP - 06, aumento 66.15, NX.

Detalhe de biotita granodiorito com microclínio pertítico com geminação arqueada, englobando sericita, e em contato com clorita. 


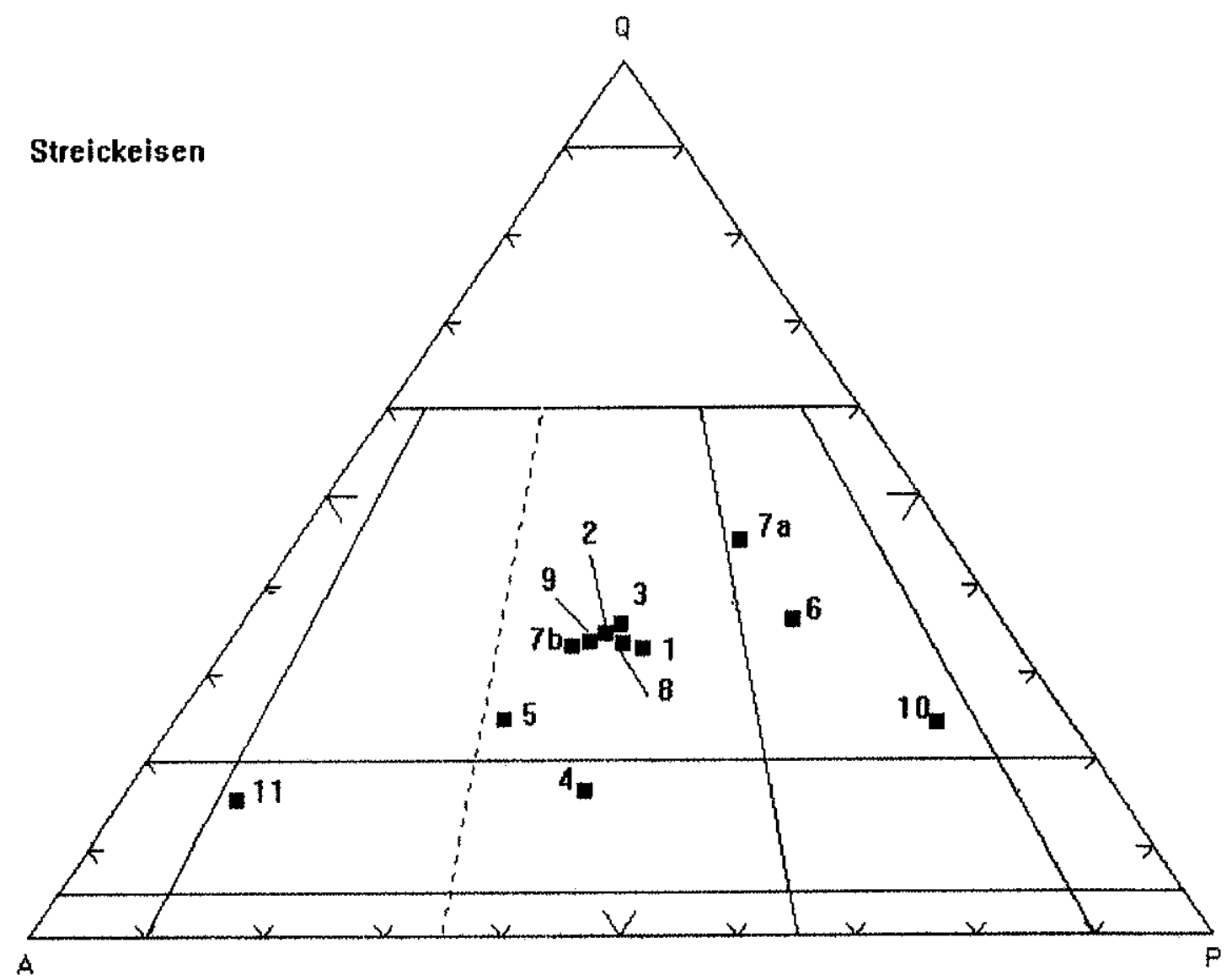

Fig. 22 : Diagrama QAP dos Granitos Hidrotermalizados Tipo Matupá.

$1 \quad$ PA148

$2 \quad$ MP 03

3 - MP 07

$4 \quad$ MP 10

$5 \quad$ MP 12

6 MP 06

7a MPSR 03a

7b MPSR 03b

8 MP 22

9 MP 04

$10 \quad$ MP 05

11 MP 12 a
Monzogranito com Epídoto e Clorita

Biotita-Epidoto Monzogranito

Biotita Monzogranito com Clorita e Sericita

Clorita-Pirita-Sericita-Quartzo Monzonito

Pirita-Calcita-Sericita Monzogranito

Clorita-Sericita Granodiorito

Biotita Granodiorito

Epídoto-Biotita Monzogranito

Biotita Monzogranito com Sericita e Epídoto

Sericita Monzogranito

Clorita - Sericita Granodiorito

Quartzo Sienito Pegmatítico 
Tabela 8: Análises químicas, norma (CIPW) e moda para os Granitos Matupá.

\begin{tabular}{|c|c|c|c|}
\hline \% $\begin{array}{c}\text { Amos } \\
\text { tra }\end{array}$ & Mp -07 & $M p-12 a$ & Mp-05 \\
\hline 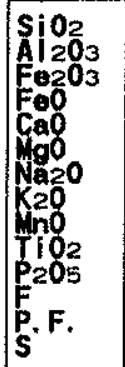 & $\begin{array}{l}66.9 \\
14.3 \\
2.0 \\
2.1 \\
2.5 \\
1: 3 \\
2.6 \\
5.2 \\
0.2 \\
0: 66 \\
0.29 \\
0.3 \\
1: 36 \\
0.18\end{array}$ & $\begin{array}{c}54.6 \\
19: 3 \\
8: 0 \\
1: 2 \\
0.26 \\
2.2 \\
2.5 \\
5.4 \\
0.2 \\
0.33 \\
0.17 \\
0.12 \\
5.51 \\
1.5\end{array}$ & $\begin{array}{l}61.2 \\
21.7 \\
2.3 \\
0.53 \\
0.07 \\
1: 1 \\
1: 5 \\
7.7 \\
0.05 \\
0.10 \\
0.02\end{array}$ \\
\hline \multicolumn{4}{|l|}{ (ppm) } \\
\hline 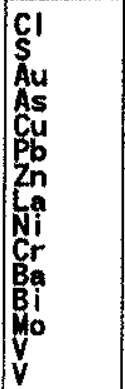 & $\begin{array}{l}69 \\
1.81\end{array}$ & $\begin{array}{l}25 \\
3.57\end{array}$ & $\begin{array}{r}N \\
1 \\
6 \\
1 \\
1 \\
24 \\
N \\
38 \\
10 \\
1\end{array}$ \\
\hline
\end{tabular}

\begin{tabular}{|c|c|c|c|c|}
\hline $\begin{array}{l}\text { Nor- } \\
\text { ma }\end{array}$ & $\begin{array}{l}\text { Amos- } \\
\text { tra }\end{array}$ & Mp-07 & $M p-12 a$ & Mp -05 \\
\hline \multicolumn{2}{|c|}{ Quartzo } & 25,27 & 17,08 & 22,09 \\
\hline \multicolumn{2}{|c|}{ Ortoclásio } & 31,35 & 33,90 & 47,27 \\
\hline \multicolumn{2}{|c|}{ Albita } & 22,23 & 22,39 & 13,18 \\
\hline \multicolumn{2}{|c|}{ Anortita } & 10,91 & 0,19 & 0,23 \\
\hline \multicolumn{2}{|c|}{ Cor indom } & 0,52 & 9,87 & 11,24 \\
\hline \multicolumn{2}{|c|}{ Hiperstenio } & 4,82 & 5,82 & 2,85 \\
\hline \multicolumn{2}{|c|}{ Magnetita } & 2,96 & 3,78 & 1,64 \\
\hline \multicolumn{2}{|c|}{ IImenita } & 1,28 & 0,67 & 0,20 \\
\hline \multicolumn{2}{|c|}{ Apatita } & 0,70 & 0,43 & 0,05 \\
\hline \multicolumn{2}{|c|}{ Hematita } & - & 5,89 & 1,26 \\
\hline \multicolumn{2}{|c|}{ Halita } & 0,01 & - & - \\
\hline \multicolumn{2}{|c|}{ Nefol ina } & 0,20 & - & - \\
\hline
\end{tabular}

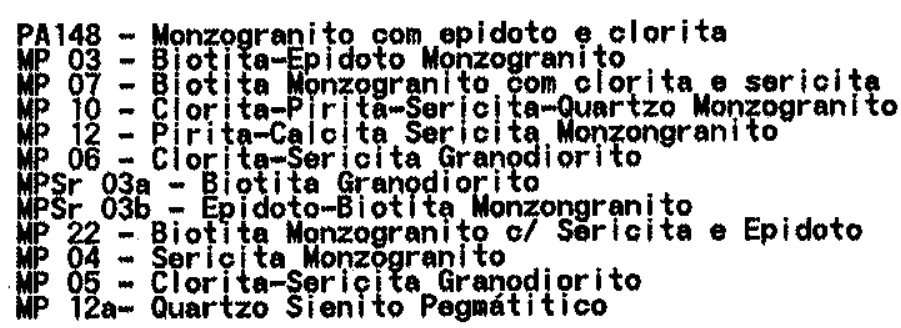

\begin{tabular}{|c|c|c|c|c|c|c|c|c|c|c|c|c|}
\hline Moda $\begin{array}{l}\text { Amos } \\
\text { tra }\end{array}$ & Mp05 & Mp07 & Mp 12 & Inp 12a & Mp03 & Mp04 & Mp06 & Mp 10 & Mp22 & \begin{tabular}{ll|}
$p s r$ \\
$p_{3}$
\end{tabular} & $\begin{array}{l}\mathrm{Mpss} \\
\mathrm{O} 3 \mathrm{~b}\end{array}$ & $P_{Q 148}$ \\
\hline Quartzo & 22 & 30 & 20 & 15 & 30 & 30 & 30 & 15 & 30 & 40 & 30 & 30 \\
\hline $\begin{array}{l}\text { Foldspato } \\
\text { Alcalino }\end{array}$ & 10 & 30 & 35 & 75 & 30 & 35 & 15 & 40 & 30 & 15 & 27 & 30 \\
\hline Plagioclásio & 05 & 25 & 03 & 05 & 25 & 02 & $x$ & 14 & 25 & 35 & 26 & 30 \\
\hline Biotita & & 05 & & & 05 & & $x$ & $x$ & 06 & 05 & 07 & $x$ \\
\hline Clorita & 05 & 03 & 9 & & 01 & $x$ & 10 & 05 & 01 & 01 & 02 & 04 \\
\hline Soricita & 55 & 03 & 18 & 05 & 03 & 30 & 40 & 20 & 04 & 03 & 02 & 01 \\
\hline Titanita & & 01 & & & & & 04 & 01 & & & & $x$ \\
\hline Apatita & $x$ & $x$ & $x$ & & $x$ & $x$ & 01 & $x$ & $x$ & & & $x$ \\
\hline Epidoto & & 02 & & & 05 & 01 & & & 03 & 01 & 05 & 04 \\
\hline Ziroăo & & $x$ & & & & 01 & $x$ & $x$ & & & & \\
\hline Carbonato & & $x$ & 10 & $x$ & & & & & & & & \\
\hline Fluorita & & $x$ & & & & & & & & & & \\
\hline Pirita & 03 & & 05 & & & & & 05 & & & & \\
\hline Opacos & $x$ & 01 & $x$ & & 01 & 01 & & $x$ & 01 & $x$ & 01 & \\
\hline
\end{tabular}

\section{Legenda:}

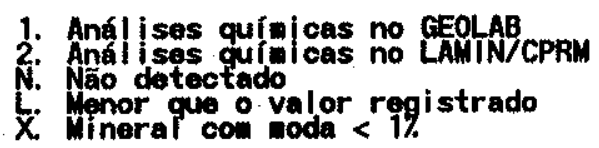


Entre as variedades petrográficas do granito Matupá, situadas, no campo dos monzogranitos e quartzo monzonitos (Figura 22), verifica-se que, ao incremento progressivo das transformações hidrotermais, associa-se uma nova paragênese mineral de alteração. No caso, os termos parcialmente transformados (biotita monzogranitos - amostras MP - 07/13/18/21/22; epidoto biotita monzogranitos - amostras MP-SR - 03b e MP - 03; e monzogranitos PA - 148) constituem rochas de coloração cinza a rósea, com tons erverdeados, textura hipidiomórfica, equigranulares, de granulação média, ou inequigranulares a porfiríticas, com fenocristais milimétricos de microclínio de cor rósea.

Os termos mais transformados, caso das amostras MP-05/10/12/23 e MP-sr-03a; são rochas de coloração cinza-esverdeada, equigranular fina a média, ou porfirítica, textura granoblástica, com 1 a $5 \%$ de pirita disseminada.

Os termos pegmatíticos (MP-12a/23a) ocorrem como bolsões ou níveis, dispostos ao longo de anisotropias estruturais preferenciais, balizadas pelos granitos hidrotermalizados piritosos e auríferos (Figura 21; Foto 9).

Os processos hidrotermais superimpostos são do tipo cloritização, sericitização, carbonatação e piritização, com provável enriquecimento em $\mathrm{K}, \mathrm{CO}_{2}$, $\mathrm{Na}, \mathrm{S}, \mathrm{Fe}, \mathrm{e} \mathrm{Au}$.

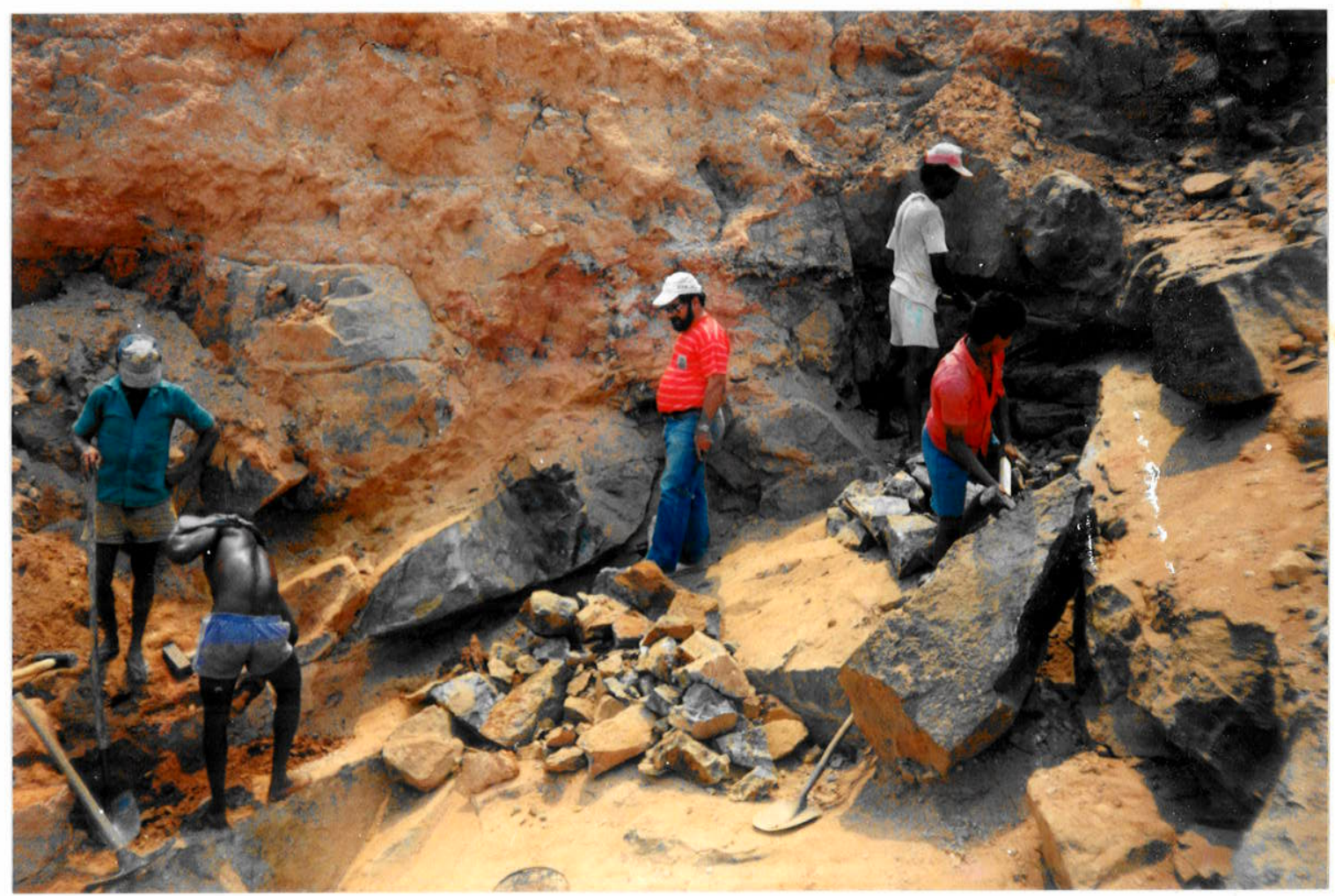

Foto 9: Granito Hidrotermalizado (MP - 10/11) com níveis pegmatíticos (MP - 12). Granito Matupá. 
Entre as transformações observadas no granito Matupá, a microclinização pode ser facilmente constatada através de texturas microscópicas, onde o feldspato potássico, no caso o microclínio pertítico, ocorre como megacristais de contornos irregulares, com inclusões de biotita, quartzo e plagioclásio, este último por vêzes subidiomórfico com as bordas corroidas. Nos níveis pegmatíticos, observa-se no microclínio pertítico intercrescimentos milimétricos de plagioclásio (albita - oligoclásio) e ainda a presença de mirmequitas, sugerindo a existência de processos de substituição de plagioclásio por microclínio (cf. Deer, Howie e Zussman, 1981). Destaca-se ainda a alteração dos plagioclásio para sericita, epidoto e calcita; e da biotita para clorita.

Observa-se que nas porções fortemente hidrotermalizadas do Granito Matupá, onde existem mineralizações auríferas do tipo disseminada, os tipos petrográficos, apresentam, sem exceção, inúmeras feições de deformação cisalhante de natureza dúctil-rúptil. Dentre algumas, citamos a existência de grãos de quartzo estirados e recristalizados, com incipiente formação de sub-grãos, lamelas de clorita e sericita deformadas, palhetas de biotita com as bordas quebradas e fraturas preenchidas por carbonato, sericita, quartzo, clorita e óxidos de ferro. Tais evidências sugerem estreito relacionamento dos granitos transformados tipo Matupá, com uma fase de cisalhamento transcorrente, de direção geral E-W, de natureza dúctil-rúptil, e com a percolação das soluções hidrotermais em uma fase tardi-a pós-deformação.

Em princípio, os processos hidrotermais que afetaram os granitos são tardi a pós-magmáticos. Os diques e apófises de microgranitos, riolitos e granitos pegmatíticos, provavelmente correlacionaveis ao magmatismo Uatamã, que interceptam os Granitos Matupá, não apresentam evidências significativas de terem sidos responsaveis pelo aporte dos fluídos hidrotermais mineralizados que transformaram os Granitos Matupá.

Entretanto, cabe realçar a existência de alguns dados que sugerem uma eventual correlação do evento Uatumã com uma fase metalogenética aurífera, no caso, nos reportamos aos seguintes pontos:

- os corpos do Granito Matupá identificados no mapa geológico (anexo 01) localizam-se na encosta norte da principal área de ocorrência de rochas pertencentes ao Grupo Uatumã;

- observa-se localmente, um maior enriquecimento em ouro no contato entre as vulcânicas riolíticas e os Granitos Matupá (Figura 21); e

- existem litótipos provavelmente pertencentes ao Grupo Uatumã, constituindo mineralizações auríferas na região garimpeira do Planeta, município de Apiacás, conforme observações pessoais deste autor e descrições efetuadas por Maraui e Veiga (1985).

Os dados petroquímicos (Tabela 08), apesar de pontuais, indicam que os granitos Matupá são fortemente peraluminosos, com indíce de aluminosidade acima de 2,0; segundo critérios de Shand (1951; in Gastal, 1988), parâmetro que 
reflete o enriquecimento em minerais micáceos, com empobrecimento em cálcio. Estes granitos mostram-se pobres em $\mathrm{Na}_{2} \mathrm{O}$ e $\mathrm{CaO}$ e relativamente ricos em $\mathrm{Al}_{2} \mathrm{O}_{3}$, $\mathrm{K}_{2} \mathrm{O}$ e $\mathrm{Au}$.

A partir da mineralogia essencial de provável composição granodiorítica, verifica-se que o plagioclásio (oligoclásio) foi intensamente transformado em sericita e epidoto, e também substituído pelo microclínio, evidenciado pela presença de bordas corroídas. O feldspato potássico representado pelo microclínio, ocorre tanto na matriz, preenchendo interstícios e assimilando os plagioclásios, como na forma de pórfiros $(0,5-4 \mathrm{~cm})$, pertíticos, com intercrescimentos milimétricos de plagioclásio.

Em algumas amostras de granitos hidrotermalizados, de coloração cinza-esverdeada (pontos MP - 05/12), com expressiva quantidade de pirita (5 $15 \%)$, em formas cúbicas milimétricas, a presença de calcita $(5-10 \%)$, associada a clorita $(10-15 \%)$ e sericita $(15-20 \%)$, sugere que os fluidos atuantes na microclinização, ao desestabilizarem os plagioclásios, liberaram cálcio para formação de calcita, com $\mathrm{CO}_{2}$, S e Au certamente trazidos pelas soluções hidrotermais (Microfoto 9 ).

$\mathrm{Na}$ amostra MP - 07, um biotita granito porfirítico com clorita, sericita e epidoto, o plagioclásio apresenta intercrescimento mirmequítico; ocorrem como acessórios apatita, pirita, calcita, fluorita e titanita, este último de hábito losangular, com minerais opacos cristalizados em suas bordas.

Em algumas porções mais hidrotermalizadas existentes nesses corpos graníticos é possível verificar a existência de um zonamento mineralógico, com um núcleo central pegmatítico, avermelhado, (MP - 12a/23a) ladeado por granitos hidrotermalizados piritosos, cinza esverdeados (MP - 05/12/23 e MP-SR 01), ambos mineralizados a ouro, conforme representação esquemática na Figura 21. Outras vezes esses granitos hidrotermalizados mineralizados ocorrem ao longo de sistemas de fraturas ou mesmo na forma de corpos irregulares (Foto 10), com coloração marrom escuro devido a alteração dos sulfetos.

\subsection{3 - Granitos Indivisos}

Durante os trabalhos de campo foram indentificados na área várias ocorrências de rochas graníticas, com grande diversidade petrográfica, observadas em afloramentos pontuais e também delimitadas através de fotointerpretação, com identificação de estruturas semi-circulares, apresentando significativo realce com as encaixantes.

Compreendem granitóides sem condições de serem individualizados no momento, mas, certamente não pertencentes ao Complexo Xingu, a maioria deles provavelmente mais antigos que os granitos Teles Pires de Silva et al. (1974/1980), admitidos como comagmáticos à Formação Iriri, do Grupo Uatumã. 


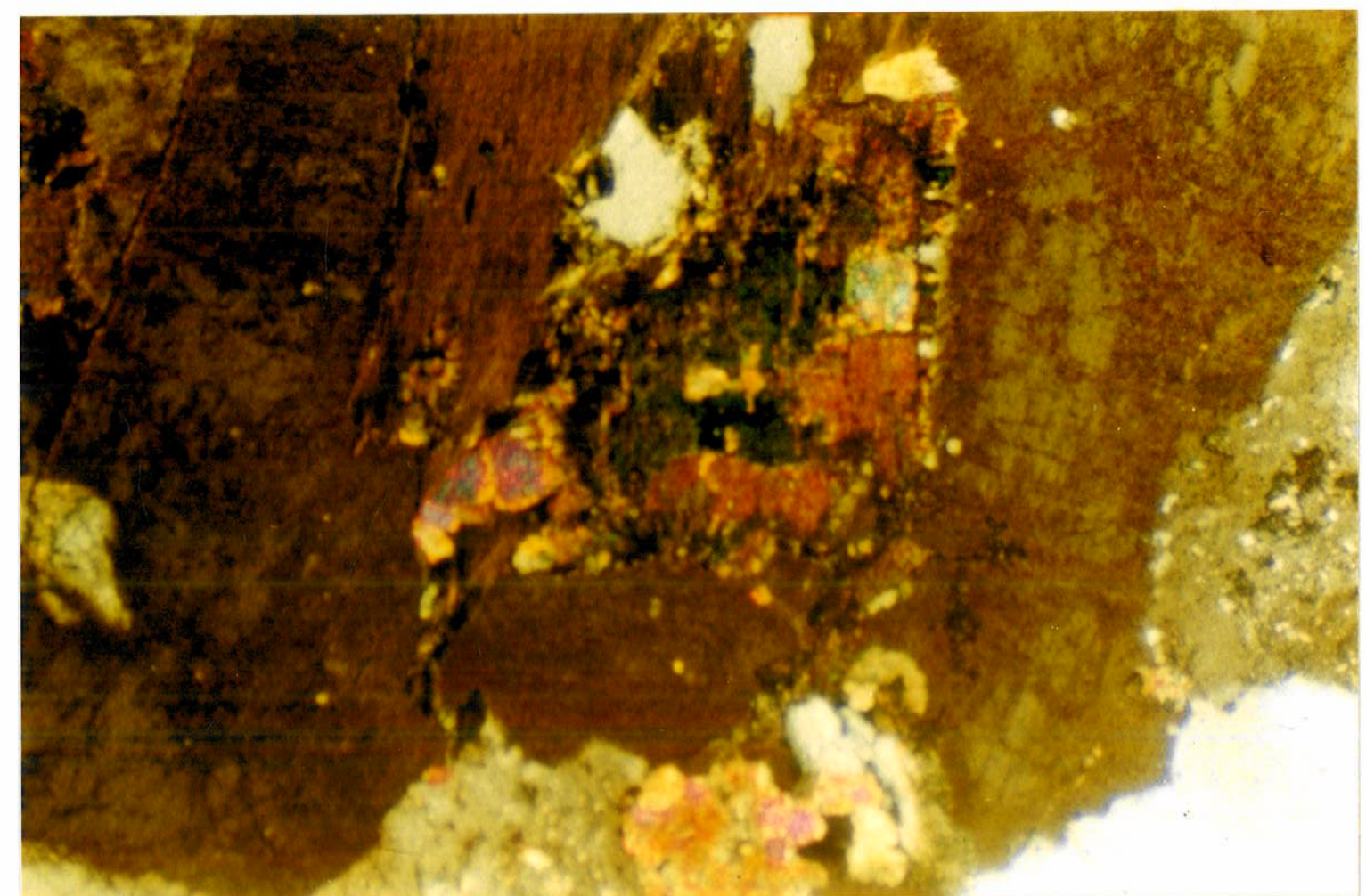

Microfoto 9: Amostra MP - 23, aumento 66.15x, NX. Detalhe de um granito hidrotermalizado apresentando plagioclásio sericitizado com inclusões de calcita, epidoto e clorita. Quartzo em sub grãos.

Foto 10: Amostra MP 04. Aspecto geral das exposições dos Granitos Matupá, com as porções mais hidrotermalizadas apresentando cor vermelho escuro.

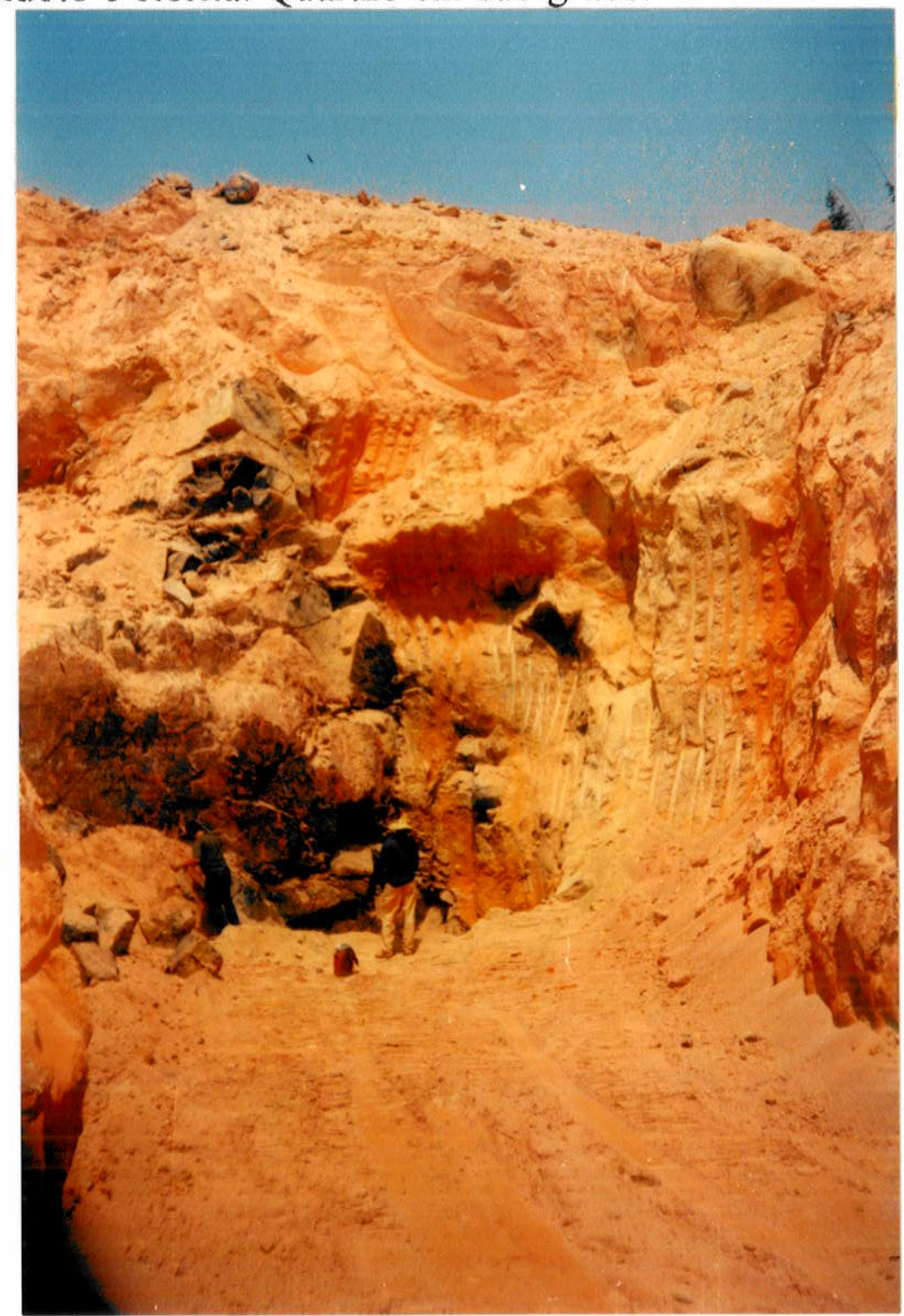


Dois tipos petrográficos merecem destaque:

Granitos pórfiros - Ocorrem na forma de apófises, principalmente nas proximidades das fraturas de cisalhamentos preenchidas por veios, caso dos filoes do Paraíba, Olerindo, Donizete e Pepita; e em afloramentos isolados, caso dos pontos GR - 52, GR - 35 e GR - 60.

Álcali granitos - Afloram principalmente em cristas destacadas no terreno na porção norte da área, representados pelas amostras GR - 01, 13, 16 e 37 . São constituidos basicamente por feldspato alcalino e quartzo. São rochas de coloração rósea-avermelhada, inequigranulares, finas a média, isótropas, constituídas basicamente por feldspato alcalino 55 - 60\% (albita e pertitas) e quartzo $(25-30 \%)$. Como acessórios ocorrem biotita, clorita, óxidos de ferro e sericita. Os dados petroquimicos apresentados na Tabela 09 evidenciam elevados teores de silica $(75-77 \%)$, potássio $(4,2-5,0 \%)$ e sódio $(3,2-3,8 \%)$ e baixos teores de cálcio $(0,08-0,44 \%)$.

\section{6 - Grupo Uatumã}

Ocorre principalmente na porção sudeste da área de pesquisa, com predomínio relativo de termos graníticos, associados a rochas vulcânicas, de composição provável variando entre riolitos, riodacitos e dacitos, com intercalações sedimentares de metarenitos e metasiltitos.

Os granitos reconhecidos neste contexo exibem relativa homogeneidade petrográfica, ausência de fenômenos cataclásticos intensos (milonitização), apresentam-se com coloração avermelhada de várias matrizes e composição predominantemente alaskítica.

Estes granitos, com características similares aos granitos tipo Teles Pires, de Silva et al. (1980), são avermelhados, de granulometria fina a grossa, equigranulares a porfííticos, por vezes granofíricos ou rapakivi. $\mathrm{Na}$ área de ocorrência do granito tipo Matupá é frequente a presença de cristas quilométricas, alinhadas segundo a direção NE-SW, sustentadas por rochas vulcânicas, subvulcânicas e sedimentos associados, admitidos como pertencentes ao Grupo Uatumã (Foto 11), os contatos com os Granitos Matupá ou Indivisos são frequentemente através de zonas de cataclase discretas, localmente com desenvolvimento de rochas hidrotermalizadas.

Não se observou, na área abrangida por este trabalho, mineralizações auríferas encaixadas em rochas típicas do Grupo Uatumã, entretanto, constatou-se a existência de inúmeros stocks, diques, apófises e sills de rochas ácidas a intermediárias que afetam as sequências mais antigas, e inclusive as fraturas mineralizadas. Aparentemente, o Grupo Uatumã não condicionou mineralizações, mas sim remobilizações, em estruturas potencialmente mineralizadas. 
Foto 11: Diques e apófises de granitos pórfiros (grp) e riolitos invadindo Granitos. Garimpo da Serrinha. Matupá.

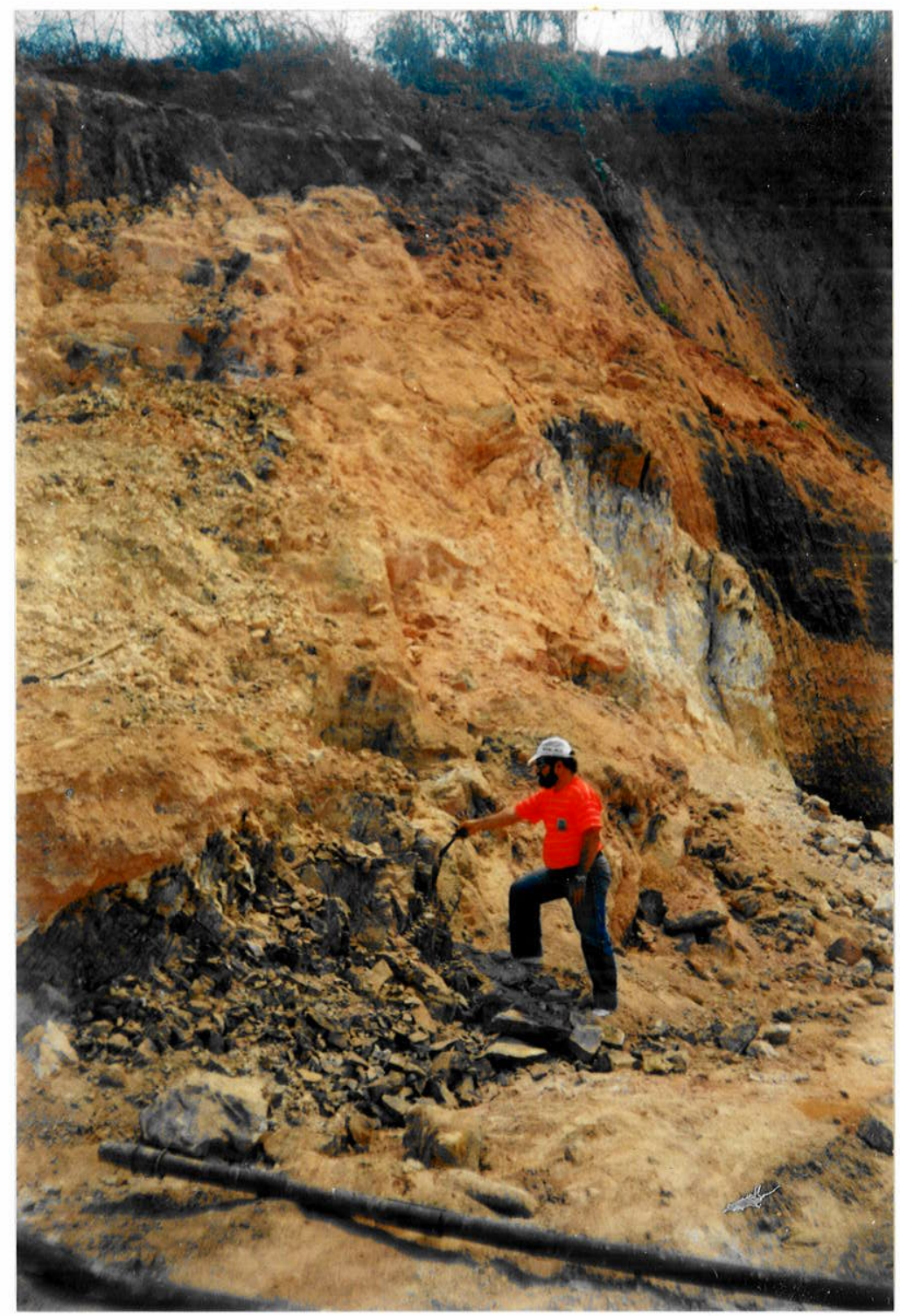

5.7 - Stocks, Diques, Apófises e Sills

Compreendem uma série de litologias de natureza nitidamente tardia que afetam as demais sequências supracitadas.

$\mathrm{O}$ atual estágio de conhecimento destes corpos não permite correlacioná-los com unidades similares já descritas no Cráton Amazônico. Desta forma, optou-se por enquadrá-los no Proterozóico Superior, apenas a nível de referência, pois seguramente devem existir corpos agrupados nesta unidade com idades fora dos limites dessa Era. Os dados petroquímicos disponíveis estão na Tabela 10 .

\section{Rochas Básicas e Intermediárias}

São rochas de coloração verde-escura a preta, granulação fina a média, isótropas, ocorrendo na formas de diques e derrames de composição variando entre andesitos e basaltos. Texturalmente, podem ser tão grossas quanto os gabros. Os diques possuem comprimento médio da ordem de 200 metros, localmente ultrapassando 1.000 metros, e espessura variando de 10 centímetros a 100 metros. 


\begin{tabular}{|c|c|c|c|c|c|c|c|c|}
\hline \multicolumn{4}{|c|}{$\begin{array}{l}\text { Tabola 09: Análises Químicas pa- } \\
\text { ra Granitos Indivisos. }\end{array}$} & \multicolumn{5}{|c|}{$\begin{array}{l}\text { Tabela 10: Análises Químicas para Gabros, } \\
\text { Diabásios, Basaltos e Andesitas. }\end{array}$} \\
\hline & $\operatorname{Gr}-A j-01$ & $\operatorname{Grm} \mathbf{A j} 13$ & Grmaj 16 & $\mathrm{~Pa}_{2}-02$ & $\mathrm{~Pa}_{2} 49$ & Pam77 & $\mathrm{Pa}_{\mathrm{a}-77}$ & Pam 146c \\
\hline 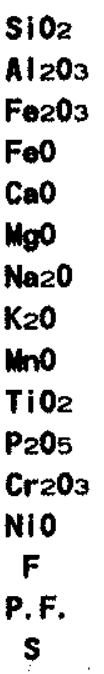 & $\begin{array}{l}77.0 \\
12.0 \\
1.2 \\
0.14 \\
0.08 \\
0.10 \\
3.2 \\
4.7 \\
0.02 \\
0.18 \\
0.05 \\
0.003 \\
0.003 \\
0.044 \\
1.31 \\
0.005\end{array}$ & $\begin{array}{l}75.0 \\
12.6 \\
0.68 \\
1.1 \\
0.42 \\
0.24 \\
3.6 \\
5.0 \\
0.06 \\
0.2 \\
0.08 \\
0.003 \\
L .003 \\
0.77 \\
0.009 \\
0.009\end{array}$ & \begin{tabular}{|l|}
75.1 \\
13.4 \\
0.52 \\
0.79 \\
0.44 \\
0.36 \\
3.8 \\
4.2 \\
0.05 \\
0.18 \\
$L 0.05$ \\
$L \quad 0.003$ \\
$L \quad 0.003$ \\
0.032 \\
0.99 \\
0.005
\end{tabular} & $\begin{array}{l}46.3 \\
14.2 \\
7.9 \\
8.5 \\
8.4 \\
6.2 \\
2.7 \\
1.2 \\
0.28 \\
1.0 \\
0.29\end{array}$ & $\begin{array}{r}47.8 \\
17.0 \\
7.2 \\
4.9 \\
8.8 \\
5.4 \\
3.4 \\
1.3 \\
0.12 \\
0.83 \\
0.67\end{array}$ & $\begin{array}{l}46.0 \\
14.2 \\
13.1 \\
6.2 \\
4.9 \\
4.0 \\
2.2 \\
1.7 \\
0.22 \\
1.1 \\
0.85\end{array}$ & $\begin{array}{l}50.5 \\
12.5 \\
7.6 \\
7.6 \\
6.3 \\
4.0 \\
2.8 \\
1.7 \\
0.29 \\
2.1 \\
1.0 \\
0.005 \\
0.003 \\
0.15 \\
2.55 \\
0.22 \\
\end{array}$ & $\begin{array}{c}45.0 \\
16.1 \\
5.0 \\
8.8 \\
9.4 \\
7.0 \\
2.7 \\
1.3 \\
0.39 \\
1.7 \\
0.2\end{array}$ \\
\hline \multicolumn{9}{|l|}{ (ppm) } \\
\hline $\begin{array}{l}\mathrm{Cl} \\
\mathrm{S} \\
\mathrm{Au} \\
\mathrm{As} \\
\mathrm{Cu} \\
\mathrm{Pb} \\
\mathrm{Zn} \\
\mathrm{La} \\
\mathrm{Ni} \\
\mathrm{Cr} \\
\mathrm{Ba} \\
\mathrm{Bi} \\
\mathrm{Mo} \\
\mathrm{V}\end{array}$ & $\begin{array}{l}22 \\
N\end{array}$ & $\begin{array}{l}83 \\
0.22\end{array}$ & $\begin{array}{l}21 \\
N\end{array}$ & $\begin{array}{c}0.21 \\
N \quad 0.02 \\
\\
28 \\
8 \\
70 \\
30 \\
38 \\
78 \\
240 \\
N \\
L 2.0 \\
292\end{array}$ & $\begin{array}{c}0.16 \\
N \\
124 \\
8 \\
57 \\
29 \\
45 \\
24 \\
130 \\
N \\
L \quad 2.0 \\
140\end{array}$ & $\begin{array}{c}0.27 \\
N \\
11 \\
18 \\
91 \\
30 \\
2 \\
5 \\
54 \\
N \\
N \\
200\end{array}$ & $\begin{array}{r}20 \\
N\end{array}$ & \\
\hline \multicolumn{4}{|c|}{$\begin{array}{l}\text { Gr-Aj-01 - alcal igranito } \\
G r-A j-13 \text { - alcal igranito } \\
G r-A j-16 \text { - micro alcal igranito }\end{array}$} & $\begin{array}{l}\operatorname{Pa}=02 \\
\operatorname{Pa}-49 \\
\operatorname{Pa}-77 \\
\mathrm{~Pa}-146 c\end{array}$ & \multicolumn{4}{|c|}{$\begin{array}{l}\text { - Diabásio } \\
\text { - Gabro } \\
\text { - basalto/andesito } \\
\text { - basalto com porfiros } \\
\text { de plagioclasio }\end{array}$} \\
\hline
\end{tabular}

\section{Legenda:}

1 - Análises químicas no GEOLAB

2 - Análi ses quílicas no LAMIN/CPRM

N - N5o dotectado

L. Menor que o valor registrado 
Nas proximidades dos pontos PA - 49/50 (gabros) e PA - 143 (dioritos) é provável a existência de um corpo máfico diferenciado.

As direções preferenciais de posicionamento dos diques são: N5060W, N60-70E e N45-50E.

\section{Rochas Ácidas}

Ocorrem sob a forma de diques de microgranitos, granófíros, granitos pegmatíticos e riolitos, observados principalmente nas proximidades das zonas mineralizadas, no contexto dos corpos de biotita granito do tipo Matupá (Figura 21; Foto 11).

\section{8 - Unidade Sedimentar}

Constitui uma pilha de sedimentos clásticos depositados em bacias restritas, alongadas e provavelmente condicionadas por falhas resultantes da acomodação de blocos ou mesmo representando paleocanais vinculados a ambientes deposicionais mais amplos, cujos registros não são passíveis de observação face ao grau de arrasamento do relevo.

Nos locais de ocorrência é possivel estimar uma espessura da ordem de 30 metros para o pacote, tomando-se como referência um horizonte constituído por um siltito ferruginoso com niveis hematíticos.

As exposiç̃̃es observadas permitem supor a existência de uma sedimentação rítmica, com períodos de aquiescência tectônica, representado por uma sedimentação pelítica, com argilitos e niveis de siltitos, maciços, de coloração amarelada, desenvolvendo um perfil de alteração com típicas argilas mosqueadas; alternados com períodos de intenso fluxo de sedimentos grosseiros, representado por conglomerados, com espessura ao redor de 1 metro, que gradam para microconglomerados e arenitos pouco consolidados de coloração esbranquiçada.

Os sedimentos conglomeráticos são constituídos por fragmentos angulosos e subangulosos, centimétricos a decimétricos, de quartzo sacoroidal e leitoso e, mais raramente fragmentos de rochas graníticas. Esses conglomerados constituem, localmente, mineralizações auríferas.

Veios de quartzo sacaroidal de $20 \mathrm{~cm}$ de espessura e atitude $\mathrm{N} 4 \mathrm{OE} / \mathrm{sv}$ cortam a pilha.

A orientação dos leitos conglomeráticos sugere uma direção geral N20-30W, para a paleo-bacia, direção esta subparalela à principal zona de cisalhamento dúctil que afeta a região.

\section{9 - Aluviões Recentes}

Correspondem aos sedimentos de natureza aluvionar depositados ao longo das principais drenagens que cortam a região, com maior representatividade 
nas planícies aluviais (A) dos rios Peixoto de Azevedo e Braço Norte, conforme Mapa Geológico, em anexo.

As aluviões apresentam-se frequentemente com a seguinte disposição, da base para o topo:

$\mathrm{Na}$ base do pacote aluvionar, frequentemente ocorre um nível de cascalho com fragmentos subarredondados de quartzo dispostos em um matriz areno-argilosa, com uma espessura oscilando entre 10 centímetros a 1 metro.

No nível intermediário, é comum a ocorrência de sedimentos arenoargilosos inconsolidados, mal selecionados, com espessura média de 2 a 5 metros.

No topo do pacote, ocorre um horizonte de material areno-argiloso, transportado, em avançado processo pedogenético, de coloração marronavermelhada e espessura da ordem de 4 metros, que grada para um solo superficial rico em matéria orgânica, frequentemente com espessura menor que 1 metro.

A espessura e a distribuição dos materiais deste pacote depende principalmente do posicionamento em relação à declividade das vertentes, proximidade do canal da drenagem e do tipo e amplitude do vale. Pode ocorrer ainda mais de um nível aluvionar, evidenciado pela presença de um falso bedrock. 


\section{6 - GEOLOGIA ESTRUTURAL}

Em relação à Geologia Estrutural é possivel individualizar dois padrões de estruturas mais proeminentes, que constituem Domínios Estruturais facilmente caracterizados, tanto em função da homogeneidade e padrão fotogeológico das estruturas, como pela natureza dos terrenos em que as mesmas estão superimpostas.

Nestes termos, foram definidos dois domínios estruturais na região. Um domínio mais antigo, com registro principalmente na região de ocorrência dos terrenos arqueanos (embasamento granito-gnaíssico), que ocupa o centro e norte da área de pesquisa, denominado informalmente de Domínio Xingu e o outro mais jovem, bem representado na porção sudeste da área, onde afloram os litótipos pertencentes ao Grupo Uatumã, aqui denominado de Domínio Iriri. Esta terminologia está de acordo com a utilizada por Barbosa el. al. (1985).

Os domínios sugeridos são em parte compatíveis com a estruturação proposta por Araujo et al. (1975) e Souza et al. (1979), que identificaram três sistemas de falhamentos na região, no caso:

- um sistema mais antigo de direção geral NW, que afetou principalmente os litotipos do Complexo Xingu, correspondendo no caso, ao Domínio Xingu, proposto acima;

- um sistema intermediário, de direção NE, marcante na região de ocorrência dos litotipos pertencentes ao Grupo Uatumã, que corresponde à área característica do Domínio Iriri, e

- um sistema mais jovem de direção aproximada $\mathrm{E}-\mathrm{W}$, que afeta ambos os domínios e está evidenciado, principalmente no Domínio Iriri, por zonas de cisalhamentos discretas de natureza dúctil-rúptil, com movimentação predominantemente transcorrente.

Nosso entendimento é que os três sistemas citados são recorrentes e herdados da estruturação arqueana deste terreno. É notório que os sistemas mais antigos estão representados pelas estruturas NW e E-W, de natureza dúctil a dúctilrúptil, evidenciados principalmente pelas zonas de cisalhamentos transcorrentes. Enquanto isto, o sistema NE é sin-a pós-Uatumã, eminentemente rúptil, e afeta os demais sistemas.

Essa subdivisão em domínios com base no padrão estrutural também apresenta implicações no que se refere às atividades granitogênicas, constatação já efetuada por Barbosa et. al. (1985). Estes autores sugerem que o posicionamento de vários maciços graníticos da Amazônia Centro Meridional, está relacionado a áreas ou domínios estruturais defínidos, com metalogenias específicas e evolução petrogenética característica. 


\section{1 - Domínio Xingu}

As feições estruturais observadas neste domínio são características de plataformas pré-cambrianas, em especial de terrenos granito-gnaíssicos arqueanos.

Neste tipo de terreno existente na região, as estruturas de formacionais geradas sob regime coaxial, provavelmente associadas a ciclos tectônicos anteriores, estão quase totalmente obliteradas pelas foliações cataclásticas. Nos raros afloramentos de gnaisses onde é possivel verificar o bandamento metamórfico ( $\mathrm{S} 1$ ), verifica-se que o mesmo apresenta-se com atitudes variando entre $\mathrm{N} 40 \mathrm{~W}$ a $\mathrm{N} 40 \mathrm{E}$, frequentemente sub-verticalizadas. Localmente, foram observados padrões de redobramento coaxial tipo cogumelo, que evidenciam pelo menos duas fases de deformação, em condições metamórficas compatíveis com a fácies anfibolíto (amostra PA - 122/127).

Nas poucas exposições de restos de sequências supracrustais é possivel constatar que as mesmas constituem corpos restritos, encravados no embasamento granito-gnaissico. Nestas rochas, as estruturas primárias ou deformacionais pré-cisalhamento são reliquiares, e o metamorfismo situa-se no limite do fácies xisto verde.

No Domínio Xingu, as estruturas mais proeminentes constituem um sistema de mega-zonas de cisalhamentos dúcteis (ZCD) que se estendem por mais de $20 \mathrm{Km}$, segundo as direções preferenciais N15-20W e N35-45W (cf. Mapa Geológico; anexo 01). Estas zonas de cisalhamento são evidentes em produtos cartográficos e perfeitamente identificadas no terreno através de persistentes lineamentos estruturais constituindo uma das raras expressões de relevo no embasamento, inclusive servindo como divisor natural de águas, condicionando os interflúvios entre os córregos Zé Deco, Baixão Novo, Baixão Velho, Micharia e Peteca, entre outros.

A nivel regional, nota-se neste segmento da Província Amazônia Central, principalmente na área correspondente a depressão interplanática da Amazônia Meridional (Figura 03), a existência de uma macro-estruturação, configurando blocos limitados por grandes lineamentos de direção W-NW. O bloco do embasamento que corresponde à depressão interplanáltica (Figura 03), limita-se a norte com as mega-estruturas que condicionam a borda sul do Graben do Cachimbo, e a sul com o Graben dos Caiabis de Silva et. al. (1980).

O padrão regional das estruturas sugere uma distribuição en echelon com os binários de deformação principais posicionados segundo a direção geral W$\mathrm{NW}$, e as estruturas subordinadas dispostas obliquamente segundo a direção N-NW.

Este padrão pode ser verificado, tanto no arranjo espacial das estruturas impressas no embasamento da Província Amazônia Central, que limitam a sul este segmento cratônico, como na disposição de estruturas herdadas, recorrentes durante o proterozóico médio, quando da instalação e desenvolvimento dos Grabens do Cachimbo e Caiabis. 
A ambiência e posiocionamento geotectônico, associado a distribuição geométrica das estruturas observadas nas zonas de cisalhamentos dúcteis, evidenciam o predominio de uma tectônica transcorrente, durante a evolução arqueana deste segmento cratônico.

$\mathrm{Na}$ área mapeada, em todos os níveis de observação, sejam mapas, imagens, afloramentos oul lâminas petrográficas, é marcante o padrão anastomosado dessas zonas de cisalhamento, e o seu caráter preferencialmente transcorrente, evidenciado pelas seguintes estruturas:

- foliações miloníticas sub-verticais;

- eixo sub-verticais de estruturas sigmoidais;

- lineações de estiramento com mergulhos sub-horizontais;

- veios de quartzo preenchendo fraturas sub-verticais, e

- dobras de arrasto com eixos (N30-50W) paralelos ao eixo de estiramento (X),

Durante o mapeamento, verificou-se que as foliações miloníticas e lineamentos medidos nas zonas de cisalhamento dúcteis apresentavam uma dispersão significativa, muitas vezes não sendo possível identificar uma dada foliação como "Sm" ou "c", face sobretudo à longa história deformacional, com recorrência de eventos, rotação de eixos e/ou mesmo mudanças de regimes (compressivos/extensionais).

O levantamento sistemático dos veios de quartzo mineralizados (Tabelas 11, 12 e 13), mostra uma grande concentração de veios ao longo das estruturas de cisalhamentos, que se estendem das imediações da cidade de Peixoto de Azevedo até as localidades de Flor da Serra e Aragão, conforme mapa geológico (anexo 01).

A partir das constatações relatadas, buscamos estabelecer padrões de fraturamento (estruturas planares) e lineamentos que permitissem estabelecer domínios homogêneos, utilizando para tal dos modelos experimentais, sintetizados na Figura 08, desenvolvidos incialmente por Ríedel (1929) e aprimorados por Tshalenko (1968; in Harris, L. B., 1986), Roberts (1987), Hodgson (1989) e Baxter et. al. (1991).

Neste caso, como o enfoque principal do trabalho é metalogenético, definimos no contexto das estruturas cisalhantes, que caracterizam o Domínio Xingu, 5 (cinco) sistemas mineralizados, abordados com detalhes no sub-item 7.1, denominado "Depósitos do Tipo I".

\section{2 - Domínio Iriri}

Ocorre em uma região restrita na porção sudeste da área, onde afloram rochas pertencentes ao Grupo Uatumã e ao Granito Matupá. 
Tabela 11: Fillos appeados na regito de Guaranta do Horte

\begin{tabular}{|c|c|c|c|c|c|c|c|c|c|c|c|c|}
\hline Hinero bo & $\begin{array}{l}\text { Dencouinado } \\
\text { Local }\end{array}$ & At itude $\mathrm{E}$ & $\begin{array}{c}\text { Espesstura } \\
(\mathrm{cu})\end{array}$ & (46) & 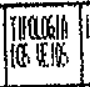 & (anditis & $\begin{array}{c}\text { Gar ipado } \\
9 / \mathrm{w}^{3}\end{array}$ & 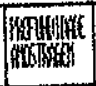 & $\begin{array}{l}\text { Paragênese } \\
\text { Hineral } \\
\text { a }\end{array}$ & $\begin{array}{l}\text { E1. ass. } \\
\text { acs veios }\end{array}$ & Pritón & $\begin{array}{l}\text { Kotureza da rocha } \\
\text { encaikante }\end{array}$ \\
\hline$G r-A j-05 \mid \mathrm{Fi}$ & Filso & $\log _{25} 201$ & $20-30$ & 300 & $5 / 7$ & $129,1,2$ & $20-1200$ & 25 & $\left\{\begin{array}{l}P y, \\
C_{1}, C_{0}, \text { he } \\
C_{1}\end{array}\right.$ & & $\begin{array}{l}P_{\text {Propili- }} \\
\text { tico }\end{array}$ & $\begin{array}{l}\text { Gnaisses Dioriticas } \\
\text { Hetabas icas/Granitos }\end{array}$ \\
\hline 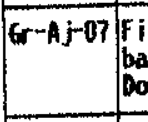 & $\begin{array}{l}\text { Fillo se- } \\
\text { bast ifo or } \\
\text { bowinsos }\end{array}$ & HENWSY 0 & $05-400$ & 500 & 5 & $\begin{array}{c}9,76\} \\
14,2\end{array}$ & $12-25$ & 24 & wa, g, cc & $\begin{array}{ll}C u & 4600 \\
\mathrm{~Pb}_{0} & 17 \\
\mathrm{Zn} & 7,7\end{array}$ & $\underset{\text { tico }}{\text { propili- Ta }}$ & Talco Clorita xisto \\
\hline Gr-Aj-11 & $\begin{array}{l}\text { Sitio do } \\
\text { Elvolcio }\end{array}$ & (rrs:1VSV & 30 & 10 & 8 & 3,7, & $5-10$ & M & py, 9 & & $\begin{array}{l}\text { Silifi- } \\
\text { cado }\end{array}$ & $\begin{array}{l}\text { Quartzo ilonito } \\
\text { brectudo }\end{array}$ \\
\hline $\begin{array}{lll}6 r-A j-12 & S i \\
\end{array}$ & $\begin{array}{l}\text { Sitio vif́- } \\
\text { va izabol }\end{array}$ & Wrouss 2 & $20-30$ & 30 & & & 20 & & & & $\begin{array}{l}\text { Ser ici- } \\
\text { tizado }\end{array}$ & Granito Awor whado \\
\hline$G r-A j-15 F_{D C}^{F}$ & Dilso & Wrow & $45-30$ & 70 & 5 & $\begin{array}{r}243,6 \\
21,6\end{array}$ & $80-150$ & & Py & & \begin{tabular}{|l|l} 
Sorici- \\
tizado
\end{tabular} & Hicros anito cisalhado \\
\hline $6 r-A j-16$ f & $\begin{array}{l}\text { Filso } \\
\text { Geraldo }\end{array}$ & HrFin/SV & & 150 & $5 / 6$ & 20,3 & & 35 & $\begin{array}{l}\mathrm{Py}, \mathrm{CP}, \mathrm{Cc} \\
\mathrm{BO}\end{array}$ & & $\begin{array}{l}\text { Serici- } \\
\text { tizado }\end{array}$ & Gnaisse Cisalthado \\
\hline $6-15-18$ & \begin{tabular}{|l|l} 
Filso do \\
Zacarius
\end{tabular} & mosiusv & 40 & 190 & 5 & $\bar{r}$ & 540 & - & 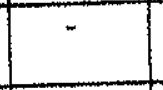 & - & & $\begin{array}{l}\text { Granito fino roseo } \\
\text { cisalhodo }\end{array}$ \\
\hline $6-A j-17$ & \begin{tabular}{|l|l} 
Filso do \\
Gringo
\end{tabular} & HenN $5 \mathrm{~s}$ & $30-50$ & 350 & & 2222,8 & & 20 & $p y, w, g$ & Cu 500 & & Granitoide cisalhado \\
\hline Gr-Aj-140 & oler indo & moOE/SV & 10 a 80 & 400 & 5 & $\begin{array}{l}44,21 \\
45,3\end{array}$ & $15-35$ & 30 & Py, $\mathrm{g}$ & & $\begin{array}{l}\text { Silici" } \\
\text { ficado }\end{array}$ & $\begin{array}{l}\text { Guaisse cisalhado } \\
\text { wilcânica ácida }\end{array}$ \\
\hline$G-A j-09$ & Valdowiro & 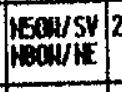 & $20-200$ & 300 & $5 / 2$ & $\begin{array}{r}17,01 \\
282,63\end{array}$ & $2-100$ & - & & & hos & $\begin{array}{l}\text { honb Gra isso/wulcânica } \\
\text { b́cida/granito }\end{array}$ \\
\hline $6-A j-20$ & \begin{tabular}{|l} 
Luiz \\
Cerezo
\end{tabular} & How & 20 & 70 & & & 40 & & & & $\begin{array}{l}\text { Serici- } \\
\text { tico }\end{array}$ & Granito Cisalhado \\
\hline $6-4 j-22$ & Hólo/Loo & $\begin{array}{l}185 y \\
50 \mathrm{~N}\end{array}$ & 30 & 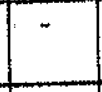 & 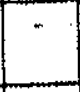 & 77,9 & $8-40$ & - & & $\bar{F}$ & 6 & $\begin{array}{l}\text { Granito cisal hado } \\
\text { Alterado }\end{array}$ \\
\hline $6 r-A j-23$ & Antonio Q: & roouly & 20 & 450 & 3 & $\begin{array}{l}54,9 \\
29,7\end{array}$ & $20-70$ & 06 & py, 9 & & & Heta Granodiorito \\
\hline$G-A j-24 L$ & Levi & $4-5 / 80 x$ & 25 & & & & & 18 & Py, 9 & & $\begin{array}{l}\text { Propiti- } \\
c 0\end{array}$ & Wetabasica Milonitizada \\
\hline $6 r-A j-18$ & Zexinho & 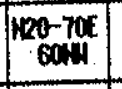 & 45 & 200 & 5 & & 120 & 20 & $9 \mathrm{Ca}$ & & $\begin{array}{l}\text { Ser ici- } \\
\text { tizado }\end{array}$ & Granito Cisalhado \\
\hline $6 r-A 5-27$ & $\begin{array}{l}\text { Antonio } \\
\text { Givicho }\end{array}$ & a ran 15 & $45-30$ & 300 & 82 & $m$ & $30-50$ & 15 & 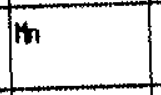 & & 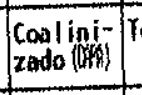 & Yonal ito Potassificado \\
\hline $6 r-A j-30$ & Toikeira & Hoow/SY & 15 & 50 & 5 & 0,57 & & 3 & py & & & $\begin{array}{l}\text { Granitoide com bandas de } \\
\text { cetabásicas }\end{array}$ \\
\hline$(G-A j-31$ & Estevo & & $5=10$ & 30 & 4 & $\begin{array}{r}4,45 \\
2 \\
\end{array}$ & 12 & 06 & $g$ & & & Granito Cisolhado \\
\hline $6 r-A j-32$ & cibos & 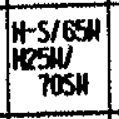 & 200 & 120 & $5 / 8 / 3$ & $\begin{array}{l}35,6 \\
5,6 \\
2,3,2\end{array}$ & 25 35 & 13 & py, & & $\begin{array}{l}\text { Sericiti } \\
\text { zadolpi } \\
\text { ritizado }\end{array}$ & Granito Milonitizado \\
\hline $6-A j-33$ & Cabral & HoDu/sV & 20 & 45 & 5 & $\begin{array}{r}4,61 \\
2 \\
\end{array}$ & 45 & 3 & $p y, g$ & & $\begin{array}{l}\text { Argili- } \\
\text { zado }\end{array}$ & Granito Cisalhado \\
\hline $6 f-A j-34$ & Br & home/sy & 45 & 120 & 5 & 17,5 & - & 2 & $g$ & & & Saitro \\
\hline$G-A j-11$ & Grotarica & Koon & & 420 & & & & & py, s & & & Granito Cisalhado \\
\hline $6 r-4 j-48$ & $\begin{array}{l}\text { Yiúva } \\
\text { Irene }\end{array}$ & 65 & 30 & 20 & 5 & 94,7 & & & 9 & & & Solo Awer whado \\
\hline $6 r-A j-49$ & Joares & HW/SV & & 100 & & & & & $\$$ & & & Solo Averw Ihado \\
\hline $6 r-A j-51$ & Sebastiva & $1+5 / 70 \mathrm{f}$ & $15-30$ & 400 & & & & & & & & Granito Alterado \\
\hline $6 r-A j-46$ & Lagoa/Coso & Himg/ & 90 & 5 & 5 & & & & & & & Granito Milonizado \\
\hline $6 r-45-54$ & Hicharia & 5 ing: & & 300 & $5 / 7$ & 640 & 150 & 30 & Py, & & $\begin{array}{l}\text { Ser iciti } \\
\text { co-capa }\end{array}$ & Grimitoide Alterado \\
\hline$G-A j-56$ & Goieno & SN/SV & $50-400$ & 250 & 5 & $12,2,0$ & $19+60$ & 10 & 9 & & $\begin{array}{l}\text { Ser icj- } \\
\text { tizado }\end{array}$ & Granitoide Altorado \\
\hline
\end{tabular}

Obs: Verificar lesenda na tabola 13 
Tathela 12: Fildes mapeados ad regiso de Peinoto de Azenedo,

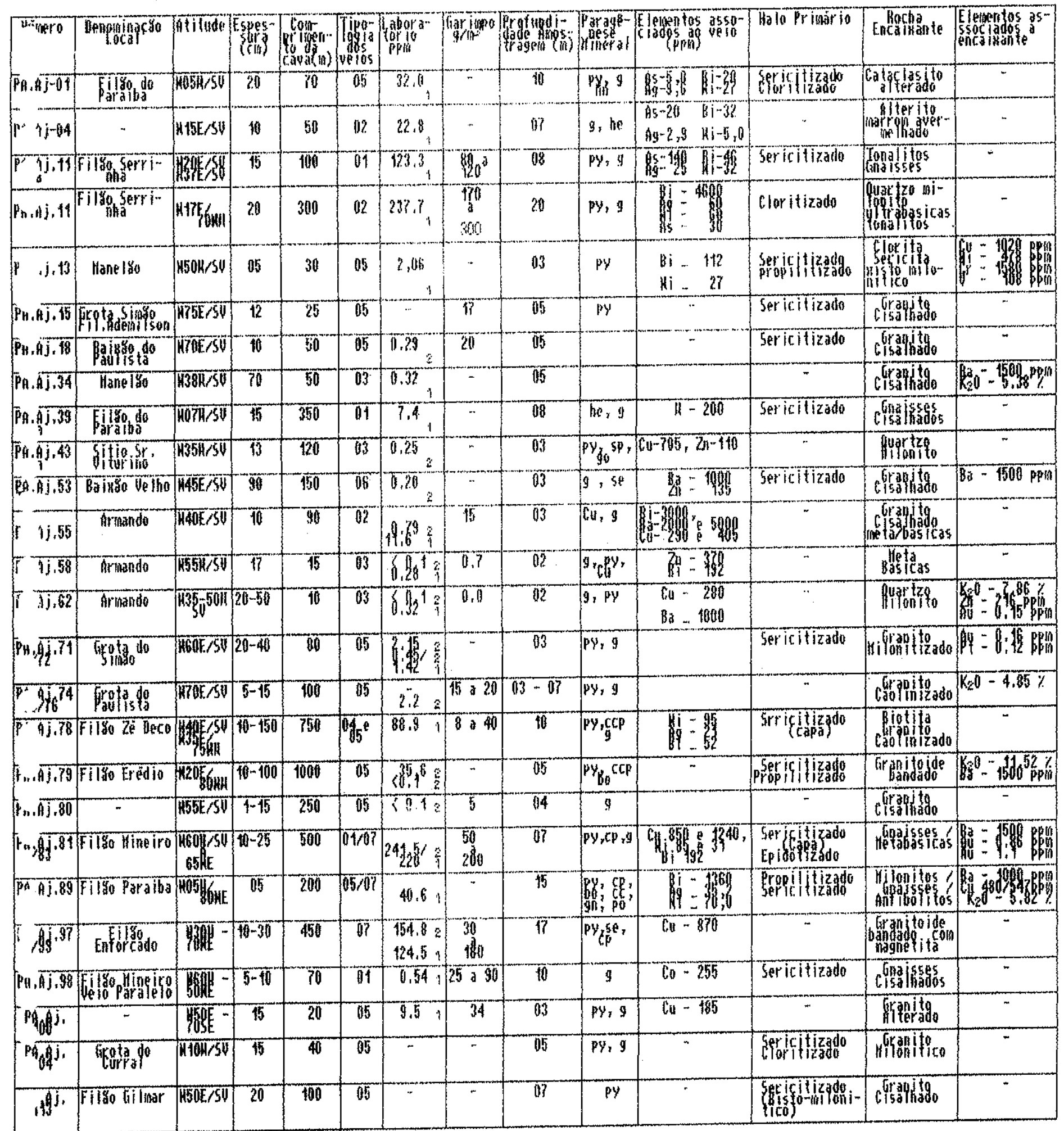

phe: Verificar a legenda na Tabela 13. 


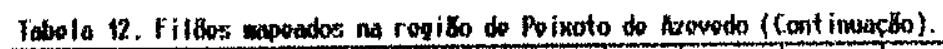

\begin{tabular}{|c|c|c|c|c|c|c|c|c|c|c|c|c|c|}
\hline Niwero & Denqminastio & Atitude & $\begin{array}{l}\text { Espas } \\
\text { Purs } \\
\text { con }\end{array}$ & 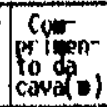 & Tipo & 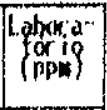 & $\cos _{9} / 9$ & Brafundi- & 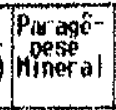 & 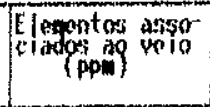 & Halo Primário & Pextha & 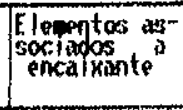 \\
\hline PA.Aj-18 & 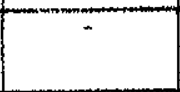 & HEOE/SV & 25 & 60 & 65 & 6.02 & + & 02 & $P y$ & $64-50$ & $\left(\begin{array}{c}\text { Sar icjtizodo } \\
\text { se } \\
\text { ilion }\end{array}\right)$ & Granito & - \\
\hline 8 ind $^{24}$ & 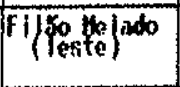 & WOSGS & $20-30$ & 400 & $01 / 05$ & 93,3 & $70-200$ & 15 & 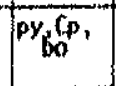 & $\because$ & petasplificado & Tonalifices & $\sim$ \\
\hline$P A . A j-126$ & Fi) $\left(\begin{array}{l}50 \\
\text { ceste }\end{array}\right)$ ado & HoSE /SV & 15 & 450 & 0 & $897 \%$ & 25 & 115 & $\mathrm{PYCA}_{\mathrm{C}}$ & ce. & $\left(\begin{array}{l}\text { ser icitizodo } \\
\text { carbopatizodo } \\
\text { copou }\end{array}\right.$ & Afpisisces & - \\
\hline PA.AF-146 & Gavitor inho & Nrot $/$ S & $10-45$ & 80 & 05 & $\because$ & + & 07 & Py &  & 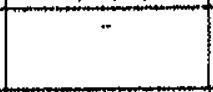 & Grapise & - \\
\hline PA.Aj-147 & Baixko howo & How/SV & $20-70$ & 45 & $03 / 06$ & $9: 8:$ & 0,0 & 01 & $p y, g, s$ & & Spricitizagso & Giabatol & 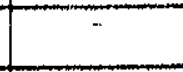 \\
\hline PA.AF 148 & Eilkodo & 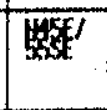 & $25-30$ & 70 & 0.5 & 5.51 & $\because$ & 08 & - & & 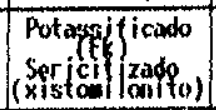 & $\begin{array}{l}\text { Brotifa } \\
\text { crisalfogo }\end{array}$ & $\begin{array}{l}\text { Avs }-3.2 \text { ppw } \\
\text { Aut }-1.7 \text { ppow }\end{array}$ \\
\hline PA.Aj-156 & FII\% Cego & 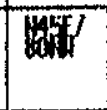 & 500 & 05 & 03 & 0.0 & 0.0 & 01 & $\sim$ & $\sim$ & Sericitizado &  & - \\
\hline PA.Aj-459 & 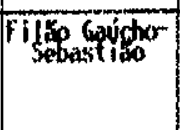 & 然高 & $15 \cdot 30$ & 4.50 & $05 / 07$ & 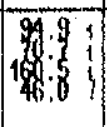 & & 30 & py & & $\begin{array}{l}\text { Ser gitizado } \\
\text { corbinatizado }\end{array}$ & $\begin{array}{l}\text { Getagrano } \\
\text { dior to } \\
\text { forlibolitos }\end{array}$ & An $-1.31 \mathrm{ppt}$ \\
\hline$P A . A j^{-161}$ & Cilaco do & NHOE/SV & $10-20$ & 150 & $\theta$ & 14.81 & & 05 & & & Sericitizado & $\begin{array}{l}\text { Gonitoide } \\
\text { anterado }\end{array}$ & As - 8.2 ppw \\
\hline$P A . \Lambda j^{-16 ?}$ & Filjădo & $455:$ & $45 \cdot 25$ & 200 &  & $184 . ?, 1$ & & Of & $p y, 9,1 n$ & & Serjcitizado & $\begin{array}{l}\text { Gipaitg } \\
\text { alterido }\end{array}$ & $\mathrm{hs}-3.8 \mathrm{pPm}$ \\
\hline PA.Aj-163 & Filag do & H17E/SV & $25 r-30$ & 700 & .65 & $23: 3 !$ & & 20 & py & & Ser icitizado & $\begin{array}{c}\text { Grancitóide } \\
\text { bandado cin } \\
\text { za claro }\end{array}$ & \\
\hline$P A . A j-168$ & Taninho & $120 / / S V$ & $90-15$ & 500 & 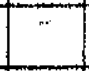 & $\cdots$ & $\because$ & $\because$ & $\dot{ }$ & in & . & $\begin{array}{l}\text { Granito } \\
\text { atterdo }\end{array}$ & \\
\hline PA.Aj 466 & Filso do & 65SW/70 & $30-150$ & 390 & $02 / 04$ & 573.01 & $10-200$ & 15 & $g$, he in & & Carbonat izacto & Grinitg & \\
\hline PA.AF 167 & Gotado & KOEM/SV & 50 & 50 & 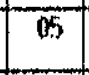 & 37.21 & - (2) & 05 & $p y, 6$ & & Ser icitizado & Granifo & \\
\hline PA.RJ-168 & $\begin{array}{l}\text { Grota do } \\
\text { sacare }\end{array}$ & Kooks & 30 & 18 & 05 & 34.01 & - & & 9 & & - & mortzo & \\
\hline$P A . A j=170$ & $\begin{array}{c}\text { Pajuyodo } \\
\text { Preto }\end{array}$ & NizE/SV & 30 & 10 & 07 & 5.61 & $=$ & 01 & g, he & & & $\begin{array}{l}\text { Gopitólde } \\
\text { Afterado }\end{array}$ & \\
\hline PA.AJ-171 & Gavitor inho & NROE/SO & 15 & 50 & $\cdots$ & $\because$ & $100-130$ & 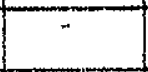 & $=$ & 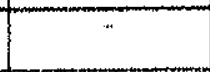 & (19) & Toualifos & $m$ \\
\hline$P A . A j=172$ & Geta do & $H S / S V$ & $10-31$ & 350 & 05 & & 1.86 & 13 & $p y, g$ &  & Sor locititindo & Sonaljtos & $\because$ \\
\hline$P A=173$ & $\mathrm{Grgada}_{\mathrm{ara}} \mathrm{ds}$ & N8 $860 \mathrm{n}$ & 20 & 250 & (A) & 97,4 & $m$ & 10 & & & Sericifizado & Comallifo & \\
\hline$P A-176$ & Hergo i" & inos./SV & 10 & 20 & 03 & $B, 11$, & & 2 & & & & Cxanjto & \\
\hline$P A-175$ & Thego II & 60 & 50 & 260 & 0506 & 12,85, & 7 & 8 & $g / C a$ & & & Solo & \\
\hline$P A-177$ & Grgta da & 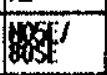 & 15 & 150 & $05 / 03$ & & 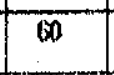 & 05 & & & Sericitico & Salbro & \\
\hline $18 A=180$ & Yein Cego & 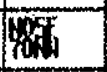 & 6 & 25 & $03 / 06$ & 2,05, & & 3 & 9 & & (Sericifim & Crapjtg & \\
\hline$P A-182$ & Piavi & $5 x^{2}$ & 10 & 10 & 05 & 4,70 & & 3 & Py & & 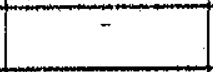 & Solo & \\
\hline$P A-183$ & Graspar & 4 & 20 & 50 & 05 & 0,14, & & 92 & 9 & & Sericitizac5o & Gonalifics & \\
\hline$P A-184$ & Made ira & HS/50E & 40 & 100 & 165 & 14,23 & 15 & 07 & 9 & & Ser igcitizapto & Crsilhado & \\
\hline$P A=185$ & Viterino & KDSE/SV & 15 & 10 & 85 & 176,2 & $15-50$ & 05 & 9 & & Sericitizaçán & Granito & \\
\hline PA- 188 & Denis & 105ST/SV & 15 & 450 & $0 ;$ & 3,35 & & 20 & & & & Tanalitits & \\
\hline$P A-167$ & Hineiro II & $H S / S V$ & 20 & 900 & 05 & 185,4, & & 03 & & & & Solo & \\
\hline$P A-189$ & Tau inda & MuAC/SV & 40 & 120 & 05 & & $\mid 30-5$ & 05 & Py,g & & Serf icit ixacho & Grapito & \\
\hline PA- 193 & Celso & HS/SV & 30 & 800 & $\overline{05}$ & 23,153 & 50 & 75 & 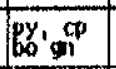 & & Soricitizado & Granito & \\
\hline$P A-19$ & Fudo Baw & moE/SV & $10-30$ & 600 & 25 & & $25-30$ & 05 & Py & & foricition & Ganito & \\
\hline
\end{tabular}

as: Verificar legendo na tabela 13. 
Tabala 13 : Filles eapeados na regilo de Matupá.

\begin{tabular}{|c|c|c|c|c|c|c|c|c|c|c|c|c|}
\hline thome & $\begin{array}{l}\text { Benowinacho } \\
\text { Lochl }\end{array}$ & At itude & $\begin{array}{l}\text { Espos- } \\
\text { sura } \\
(\mathrm{cw})\end{array}$ & $\begin{array}{l}\text { Compi- } \\
\text { contro } \\
\text { Cava }\end{array}$ & $\begin{array}{l}\text { Tipo: } \\
\text { logia } \\
\text { veios }\end{array}$ & $\mid \begin{array}{l}\text { lahar a } \\
\text { tór io } \\
\text { perw }\end{array}$ & $\begin{array}{l}\text { Gor impo } \\
c o w v^{3}\end{array}$ & $\begin{array}{l}\text { Profundi- } \\
\text { dade Anos" } \\
\text { tragen (w) }\end{array}$ & $\begin{array}{l}\text { Parage" } \\
\text { nese }\end{array}$ & $\begin{array}{c}\text { F. lomento Asso- } \\
\text { ciado ao yo io } \\
\text { (ppw) }\end{array}$ & Halo & $\begin{array}{l}\text { Naturezo da } \\
\text { rocha encai- } \\
\text { xinte }\end{array}$ \\
\hline 160.08 & $\begin{array}{c}\text { Filloo do sode } \\
\text { Comprido }\end{array}$ & HoONSS & $20-30$ & 500 & $\begin{array}{l}011 \\
07\end{array}$ & 34.7 & 15.500 & 12 & $g_{1}^{p y_{1}}$ & $A S-120$ & $\left\{\begin{array}{l}\text { Sor icitizacka } \\
\text { Carbonit izacfio } \\
\text { Clor it izaça } \\
\text { (wilonitico) }\end{array}\right.$ & $\begin{array}{c}\text { Biotita } \\
\text { Granodiorito } \\
\text { Hicogranito } \\
\text { Hotabassica }\end{array}$ \\
\hline $16-68$ & $\begin{array}{l}\text { Fiffo da } \\
\text { viova }\end{array}$ & $\mathrm{NBOC} / \mathrm{sV}$ & $15-30$ & 100 & $\begin{array}{l}0.51 \\
02\end{array}$ & 9.4 & & 10 & $\mathrm{py}, \mathrm{cp}$ & & Sericitizacho & Biotita \\
\hline Ito-24 & $\begin{array}{c}\text { Filfino } \\
\text { Coraldo }\end{array}$ & 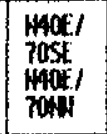 & $15-20$ & 250 & & $9.0 i$ & $20-80$ & 07 & py & & $\begin{array}{l}\text { Soricitizacko } \\
(\text { Liapa) }\end{array}$ & Biotita \\
\hline $1 p-2.4$ & $\begin{array}{l}\text { Juarez } \\
\text { Japones }\end{array}$ & HOSEN & 30 & 200 & 05 & & 35 & 15 & & & $\begin{array}{l}\text { Sor icitizado } \\
\text { (lapa) } \\
\text { Silifiracko }\end{array}$ & $\begin{array}{l}\text { Granito ci- } \\
\text { salhado com } \\
\text { op idoto }\end{array}$ \\
\hline $16-25$ & Cactiorro & EN-75N & $30-50$ & 60 & 05 & 92.0 & 20 & 03 & 9 & & & Solo \\
\hline $14-76$ & Aeroporto & 75ont & 25 & 400 & 05 & & $15-43$ & 04 & $g, p y$ & & Silificacho & $\begin{array}{l}\text { Granito } \\
\text { Cissalhado }\end{array}$ \\
\hline $1 p-27$ & $\begin{array}{l}\text { Filko do } \\
\text { Casta }\end{array}$ & E.NISW & 30 & 420 & 05 & & & & py & & Sericitizactón & $\begin{array}{l}\text { Granito } \\
\text { Cisalliado }\end{array}$ \\
\hline $16-31$ & $\begin{array}{l}\text { Filso da } \\
\text { Antena }\end{array}$ & rath & 30 & 80 & 05 & & 4 & 06 & py & & Sericitizaçán & $\begin{array}{l}\text { Granito } \\
\text { Cissalhado }\end{array}$ \\
\hline
\end{tabular}

Legendins utilizadas nas tabelas dos fitlos cadastrados.

1- Firo Assay

2 - Absorcao Atônica
3 - Dados dotidos de Correa Filho, F.C.L. (1985)

Tipologia dos veios:
01. "piritaso
- acicos, con mis de 5\% de pirita visivel.
01. piritoso - cocichado contos angulosos.
03. cisalhada - con textura ribbon, gr foos ial inos.

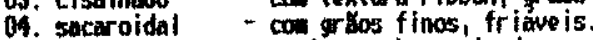
05. leitoso - macico estranquicado.

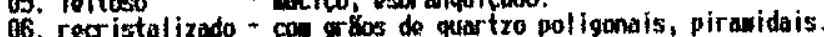
O6. berdistalizado - cow bandas de cresciunto.
08. Hilanitizado - com groses de quartzo estirodos, sigeoidais.
09. sigmoidal - "in schalon com veios sigmoidais.

$$
\begin{aligned}
& \text { paragônesse nineral: Au - ouro gon - golona } \\
& \text { py - pirita wo - wolibdenita } \\
& \text { q - colcopirita po - pirrotita } \\
& \text { m - calaquita se - sericita } \\
& \text { cc-calcosito he - hewatita } \\
& \text { cu - caprita bo - ćxidos de mangänas } \\
& \text { co - caprita gornita g- gootita } \\
& S \text { - ensofre sp - especularita } \\
& \text { Ca - cartronato }
\end{aligned}
$$


Nesse sub-domínio, observa-se que as estruturas mais antigas estão representadas por zonas de cisalhamento discretas com direção aproximada $\mathrm{E}-\mathrm{W}$, de natureza dúctil-ríptil, sem expressão topográfica, às quais associam-se alguns veios mineralizados posicionados em sistemas de fraturas de cisalhamento subordinados. As fraturas onde estão alojadas as mineralizações do tipo veio de quartzo ocorrem preferencialmente segundo as direções N40-70E e N60-85W, conforme a Tabela 13.

A feição estrutural superimposta mais marcante, entretanto, é um persistente sistema de lineamentos, com direções geral N35-45E, sustentados por rochas graníticas, balizadas por diques de diabásio e vulcânicas ácidas com sedimentos intercalados, pertencentes ao Grupo Uatumã.

Ainda nesse domínio, ocorrem dois sistemas de falhamentos, com direção N45-50E e N15-20W, que aparentemente cortam as demais estruturas. 


\section{7 - DESCRIÇÃO DOS DEPÓSITOS}

Os depósitos auriferos identificados na região foram agrupados em três tipos principais, em função da tipologia, morfologia e contexto geológico em que estão inseridos. Os depósitos do tipo I estão vinculados às estruturas geradas a partir da evolução das zonas de cisalhamento dúcteis que afetam principalmente o Domínio Xingu. Os do tipo II são filoneanos associados a pequenos corpos intrusivos, possuem distribuição restrita, e feições de cisalhamento discretas. Os depósitos do tipo III constituem mineralizações do tipo disseminado ou stockworks, alojadas em sistemas de fraturas dispostos principalmente em granitóides hidrotermalizados, definidos como tipo Matupá, no contexto do Domínio Iriri.

A relação dos filões levantados dentro do limite da área mapeada com suas características mais importantes estão listados nas Tabelas 11, 12 e 13.

\section{1 - Depósitos do Tipo I}

$O$ padrão de distribuição dos corpos filoneanos ao longo das estruturas cisalhantes principais, associado aos dados estruturais observados em campo, foram os critérios utilizados para caracterizar os sistemas mineralizados sugeridos neste trabalho.

Nestes termos, os sistemas principais de fraturamentos, que constituem mineralizações filoneanas, são descritos a seguir:

\subsection{1 - Sistema Paraíba}

Constituem veios posicionados ao longo de fraturas de cisalhamentos destrais, antéticas, balizadas por marcante foliação milonítica, com atitudes entre N00-05W. A disposição geométrica destas fraturas, com relação aos binários de cisalhamentos regionais, não estão perfeitamente definidas. Em príncipio, se trata de fraturas de cisalhamento do tipo " $\mathrm{P}$ ", conjugada a "P", com $\sigma 1$ na bissetriz (Figura 08).

A disposição geométrica das principais estruturas deste sistema está sintetizada na Figura 23.

A interpretação dos elementos estruturais sugere a existência de várias gerações de veios de quartzo, destacando-se:

- veios cisalhados ou brechados sub paralelos a fraturas "D" e "P";

- veios de quartzo leitoso bandados e sulfetados, que constituem a mineralização principal do filão do Paraíba, dispostos segundo uma fratura "P'"; e 
DISPOSICÃO RELATIVA DOS ELEMENTOS ESTRUTURAIS NO SISTEMA PARAI'BA E FILÃO DO MINEIRO

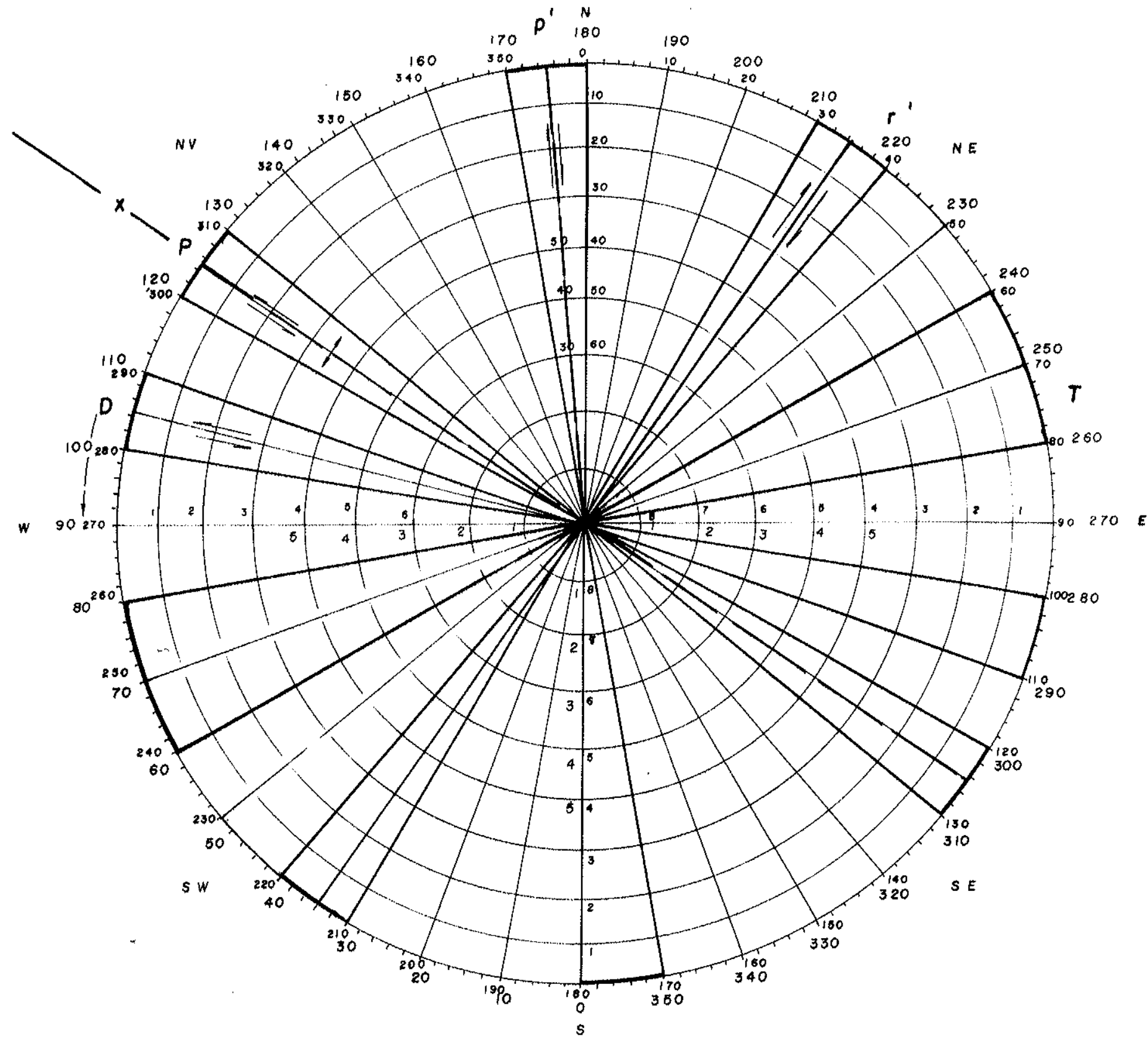

DIAGRAMA POLAR

LINEAGÕES/SUPERFICIES

LE G E N D A

- Sentido da rotação dos elementos

$x-1$ Eixo de astiromento (dobras de arrosto)

$Z / / \widetilde{V}_{1}$ Eixo de enourtomento 
- veios pegmatíticos sub-paralelos a fraturas tipo "T", muito provavelmente gerados concomitantemente às injeções graníticas que truncam as sequências cisalhadas.

A disposição dos diques de diabásio e apófises graníticas, nitidamente tardios com relação à deformação cisalhante permite propor duas interpretações para justificar o posicionamento destes corpos ao longo das direções N05-15W e N40-50E.

Os corpos dispostos ao longo da direção N05-15W, sub-paralelos à fratura principal onde está alojado o filão do Paraíba, devem estar ocupando descontinuidades estruturais geradas previamente por foliações cataclásticas tipo "sc" (Figuras 08 e 24) reativadas durante fases distensivas tardias.

Os corpos posicionados segundo a direção N40-50E (Tabela 14 e Mapa Geológico, em anexo) provavelmente ocupam fraturas " $\mathrm{T}$ " geradas localmente segundo sistemas subordinados às fraturas do cisalhamento " $\mathrm{P}$ " ", pertinentes ao filão Paraíba (cf. Mapa Geológico, anexo 01).

\subsubsection{1. - Filão do Paraíba (Pa-88/89)}

O filão do Paraíba atualmente em exploração pela Cooperativa Mista de Garimpeiros do Vale do Peixoto, em associação com a mineração Itaubí, consiste de um corpo filoneano com pelo menos três veios sinuosos e ramificados, que intersectam zonas silicificadas, com extensão da ordem de 1.000 metros, atitude N05W/55-85NE, encaixado no embasamento granito-gnaíssico-anfibolítico, com desenvolvimento de expressiva zona milonítica ao longo da fratura, conforme mostram as Figuras 24, 25 e 26.

Durante a atividade garimpeira, iniciada em 1988, este corpo filoneano foi explorado em toda sua extensão até uma profundidade média de 10 metros (Foto 12), quando então verificou-se que a espessura e os teores da mineralização variavam significativamente e apresentavam-se mais enriquecidos em pelo menos três pontos ao longo do filão, configurando ore shoots de formas tabulares.

Em um dos ore shoots que é objeto de garimpagem a uma profundidade superior a 70 metros (Foto 12 ), nota-se que o minério sulfetado e bandado está condicionado a uma encaixante básica propilitizada, que certamente foi um controle importante na deposição do ouro, similar ao verificado em vários outros depósitos do mundo, (Phillips, 1986; Groves et al, 1987).

Nos raros afloramentos, cavas e poços de garimpo existentes nas imediações deste corpo filoneano foi possivel constatar que o substrato geológico é do tipo granito-gnaíssico a gnaíssico, de composição granodiorítica, com bandas anfibolíticas orientadas localmente, no ore shoots principal (Foto 12) segundo a direção N60-65W, com espessura máxima da ordem de 25 metros. 


\section{PLANTA ESQUEMA'TICA DO FILÃO DO PARAIBAA}

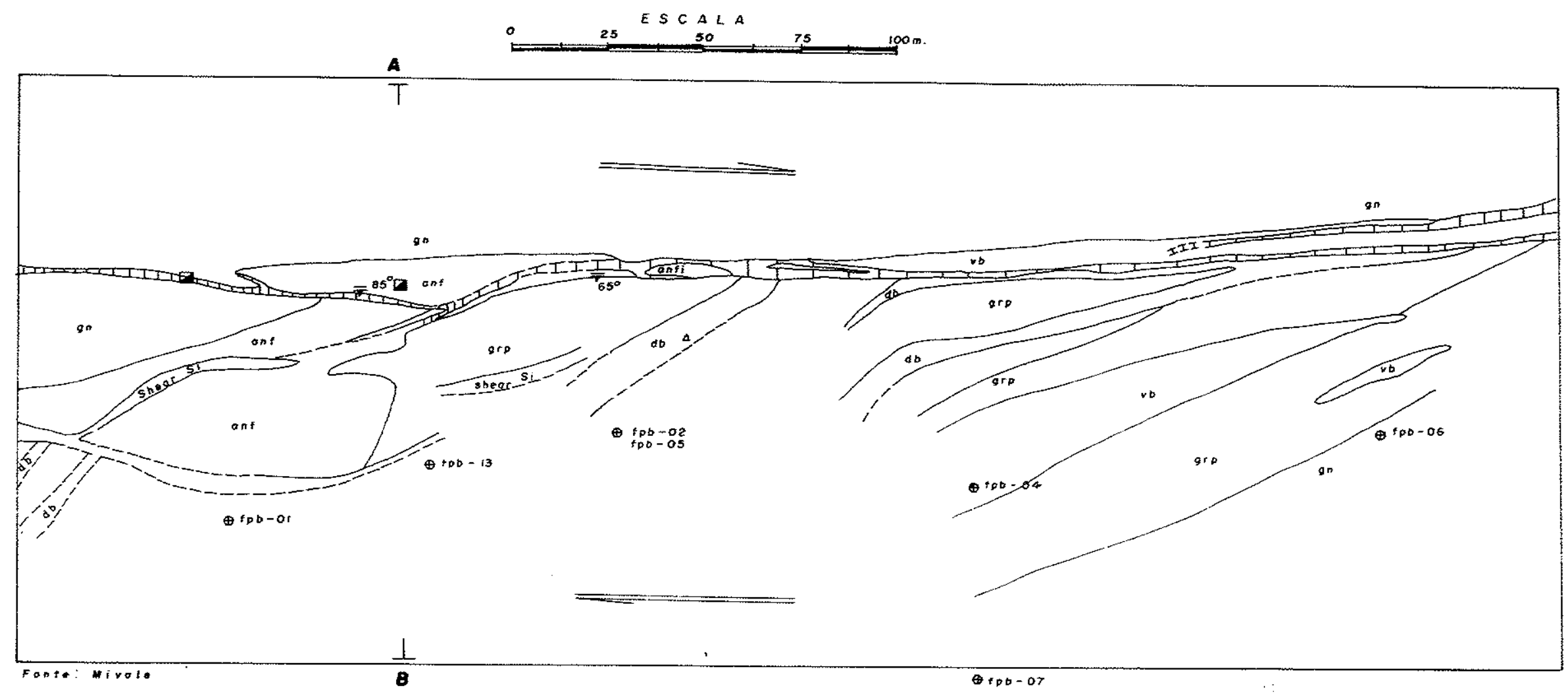

$L E G E N B A$

\begin{tabular}{|c|c|}
\hline 3000 & Veios de quartzo ouri \\
\hline ant & Anfibolitos \\
\hline do & Diaba'sios \\
\hline$v b$ & Vulcônicos basicas \\
\hline si & Zano de silficificoção \\
\hline$g n$ & Gnoisse \\
\hline
\end{tabular}

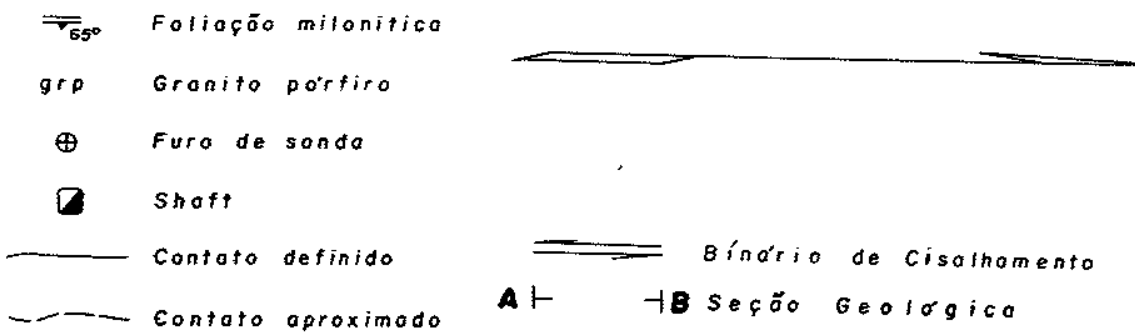

$N$ 


\section{SECGÃO GEOLO'GICA/ ESQUEMA'TICA}

\section{FILÃO DO PARAIBAA}

OESTE

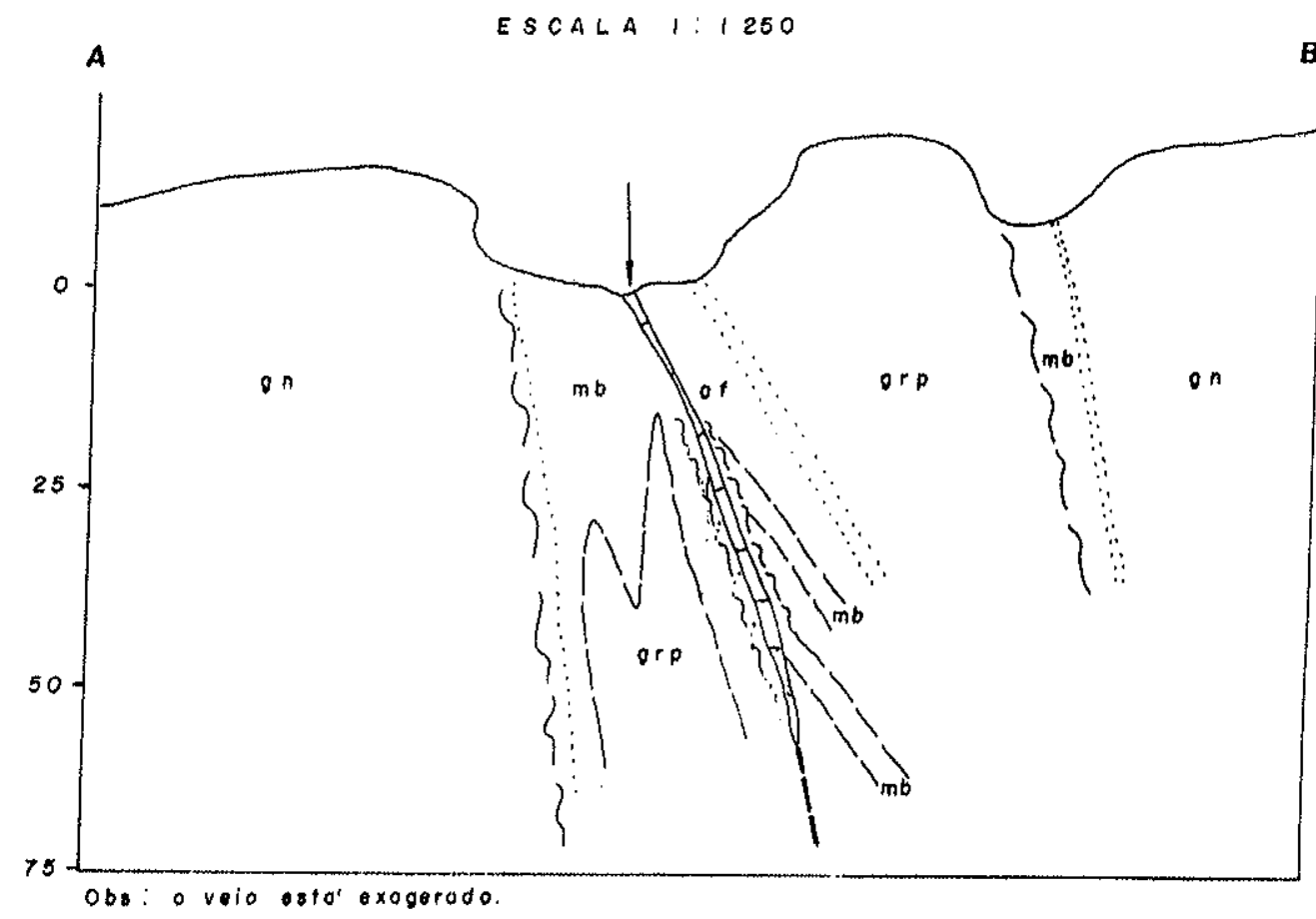

Granito poirtiro oom motriz oquigranular modia com quortzo, FK Dlogloclosio, pertiros avermethados de FK. enclaves de metaba'sloo.

จั̆

$m b$
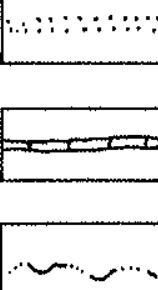

$\sim \sim \sim$

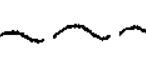

Gnaise, cinza claro, com bandos milimétecos do coloragóo olnzo escuro, com ontibolio. ciorlio.

Rocho oub-vulcônico colorạốo cinza esouro.

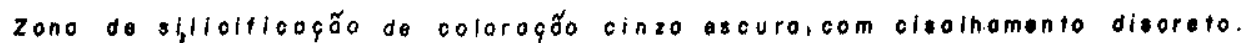

Voio de quartzo auritoro, bandado com bandos ricas em pirito, oalcopirita, bornito, pirrotito, moloduito.

Halosericitico com colactase discreto nos proximidodes do velo.

Halo milonitico com bondas propilíticos de clorito, opldoto, oorbonoto oltoron do bondos submilimeltico cam serictito, quartzo e corbonato, hidrotermalito do motaba'sicol PA $-8 \theta d)$

Bandas do cisathamento.

Anfibolito cinzo escuro a esverdoado, com bondamento fino com hornblendo (iromolita, epidatas), plagloctasio (seriorita) cornato (PA-145). 


\section{DETALHE DO VEIO DO FILÃO DO PARAI'BA}

Gadso aisathodo altorodo

ט

Volo de quortzo bondado ulfetado $(\mathrm{m} \ln$ erio)
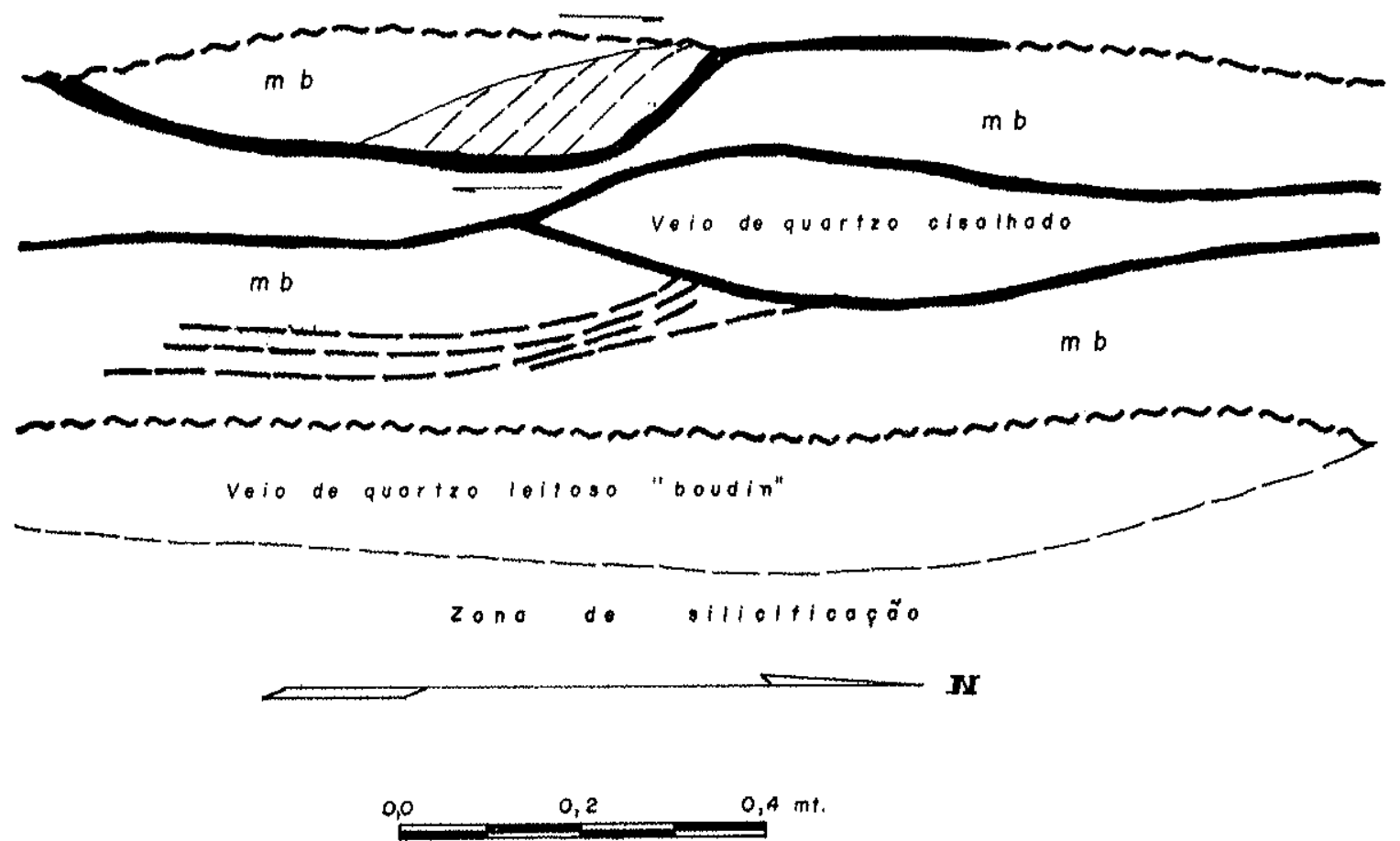

$L E$ E E N D A

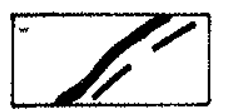

Epidoto- oorbonoto-quartzo-clorito xisto milonitico com piritas subidiomortioas dispostos sogundo o foliogo milonitica. $(P A-\theta 8 \theta)$

Moto botica hidrotermolizada com quartzo(40\%), clorito (30\%),oxido ferro $(15 \%)$, sericito $(10 \%)$, plopioclasio $(5 \%)$ epocos. $(P A-88 a)$

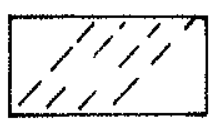

Foliogatomilonitico, indicando

Eentido de movimentagõo

N60W/65 NE. 




Foto 12: Aspecto da cava do filão do Paraíba, realçando os níveis anfibolíticos aflorantes na boca do poço principal. (PA-89).

Os anfibolitos situados nas proximidades do veio apresentam-se com bandamentos milimétricos e transformados hidrotermalmente, com plagioclásios sericitizados e hornblenda alterando-se para epídoto e tremolita.

Ao longo da direção do corpo ocorrem faixas de rochas metabásicas localmente cisalhadas e com a paragênese transformada pela interação com as soluções hidrotermais. Estas rochas ocorrem como encaixantes dos vários tipos de veios, zonas de silicificação e bandas de cisalhamento, em todas as escalas de observação (Figuras 24, 25 e 26e Fotos 13 e 14).

Nas galerias abertas pelos garimpeiros é possivel verificar claramente que tanto os veios como as bandas de cisalhamento cortam as rochas metabásicas, evidenciando que estas rochas devem ter preenchido a fratura nos estágios iniciais de geração, sob condições muito provavelmente distensionais.

O detalhe do veio esquematizado na Figura 26 apresenta pods de rochas metabásicas intensamente hidrotermalizados, localmente com foliação milonítica bem desenvolvida de atitude N60W/65NE.

Os corpos graníticos posicionados ao longo da estrutura parecem estar restritos às proximidades do filão, na forma de apófises e pequenas massas alinhadas preferencialmente segundo a direção nordeste. 
A presença de apófises de granito pórfiro, com enclaves de metabásicas, aparentemente sem evidências de cataclase, sugere o posicionamento de corpos graníticos e enxames de diques básicos, provavelmente associados às condições extensionais, certamente prevalecentes com 0 abrandamento dos esforços cisalhantes (Figura 24). A essa atividade granítica provavelmente está vinculada uma fase rúptil, com alojamento de veios pegmatíticos estreitos ( 1 a 5 $\mathrm{cm}$ ), de direção geral $\mathrm{N} 80 \mathrm{E} / \mathrm{SV}$, que cortam a foliação milonítica e o veio mineralizado principal (Foto 13). Estes veios possuem coloração rósea e são constituidos por feldspato potássico, pirita, biotita e mais raramente, carbonato, molibdenita e bornita. Fraturas tardias de direção geral N60W 65NE, sub-paralelas às fraturas "P" (Figura 23) e ao alinhamento de um dos sistemas de diques de diabásios, ocorrem preenchidas por pirita, calcopirita, carbonato e biotita, cortando os veios pegmatíticos e os milonítos (Foto 13).

Os halos hidrotermais acompanham a estrutura filoneana, sendo mais intensos e possantes nas imediações das bandas de cisalhamentos.

Nas galerias abertas pelos garimpeiros nota-se um halo mais externo desenvolvido principalmente nas encaixantes gnaíssicas, dos tipos silicificação, sericitização e potassificação (FK). De forma mais localizada, observa-se um halo mais interno, com cerca de 5 a $10 \mathrm{~m}$ de espessura, característico da alteração de rochas metabásicas, do tipo propilítico, com carbonatação, cloritização e epidotização (Fotos 13 e 14). O halo sulfetado, restrito às zonas mineralizadas, compreende as encaixantes miloniticas sulfetadas, os veios de quartzo bandados sulfetados e os veios de quartzo sacaroidal a brechados, piritosos, estes últimos observados apenas na extremidade norte do filão.

$O$ veio principal tem espessura de 0,3 a $1 \mathrm{~m}$, e localmente apresentase bandado, com leitos de 1 a $3 \mathrm{~cm}$ enriquecidos em pirita e calcopirita, com percentuais de até $30 \%$; o percentual médio de sulfetos no veio oscila entre 1 a $5 \%$ (Foto 14).

O veio principal trunca localmente a foliação milonítica, englobando fatias das encaixantes, evidenciando o processo de crack seal e sugerindo que a fase mineralizada principal é tardi a posterior ao evento cisalhante dúctil (Foto 14).

A presença de sulfetos associados ao minério milonítico, ao veio principal, ao veio pegmatítico e às fraturas tardias evidência várias fases de deposição de sulfetos, e portanto um prolongado período de circulação de fluídos, atestado pela presença de expressivos halos hidrotermais.

\section{Descrição de Seções Polidas}

No filão do Paraíba, amostras do minério sulfetado provenientes de galerias abertas a profundidades de 35 (PA-89 - a/b/c), 42 (PA-89d) e 48 metros (PA-89e) foram objeto de análise microscópica, com a seguinte caracterização petrográfica: 


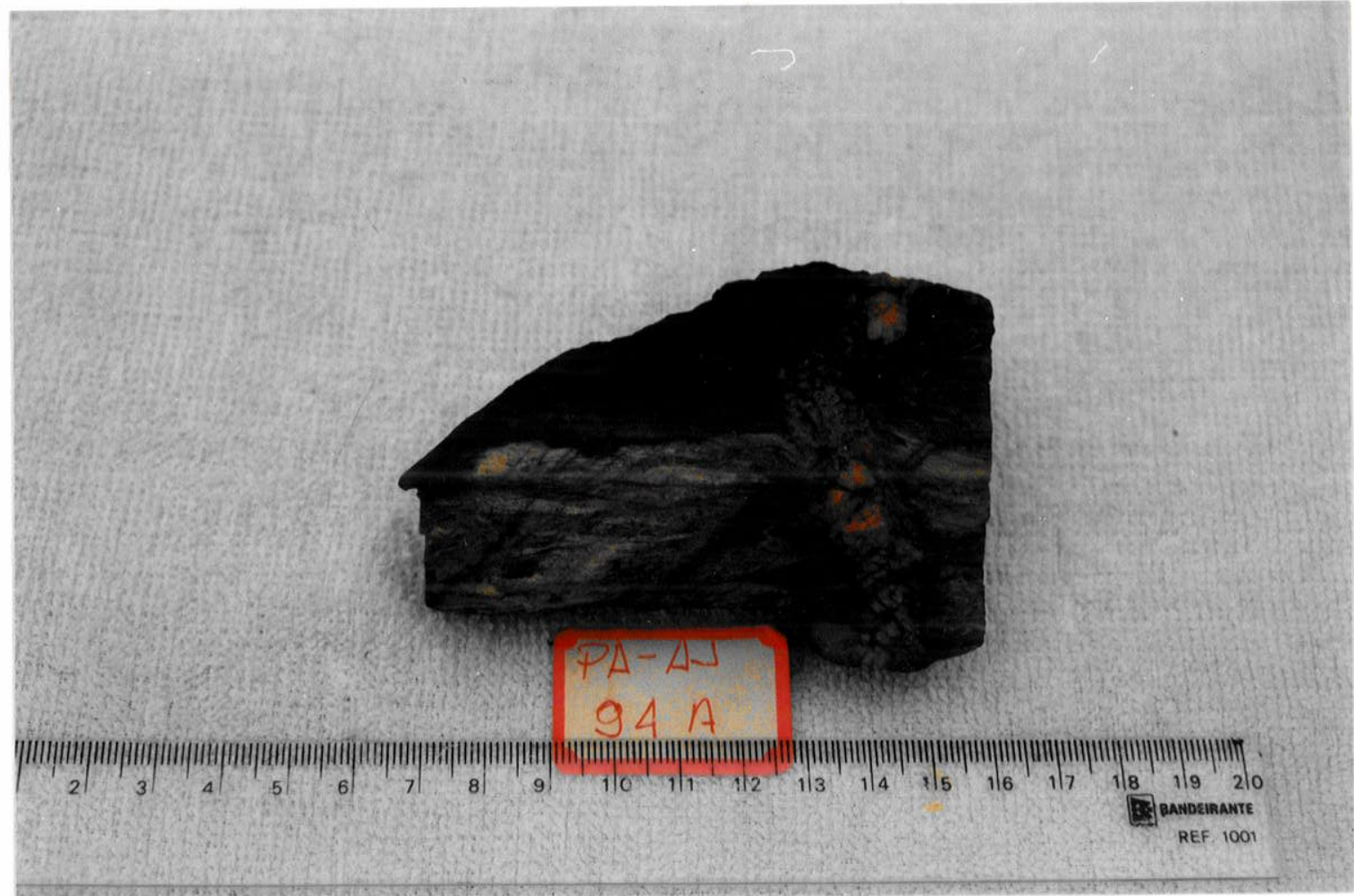

Foto 13: Amostra PA - 94a. Contato entre halos de silificação e propilítico, miloníticos; ambos truncados por veios pegmatíticos de cor rósea e direção N80E/SV.

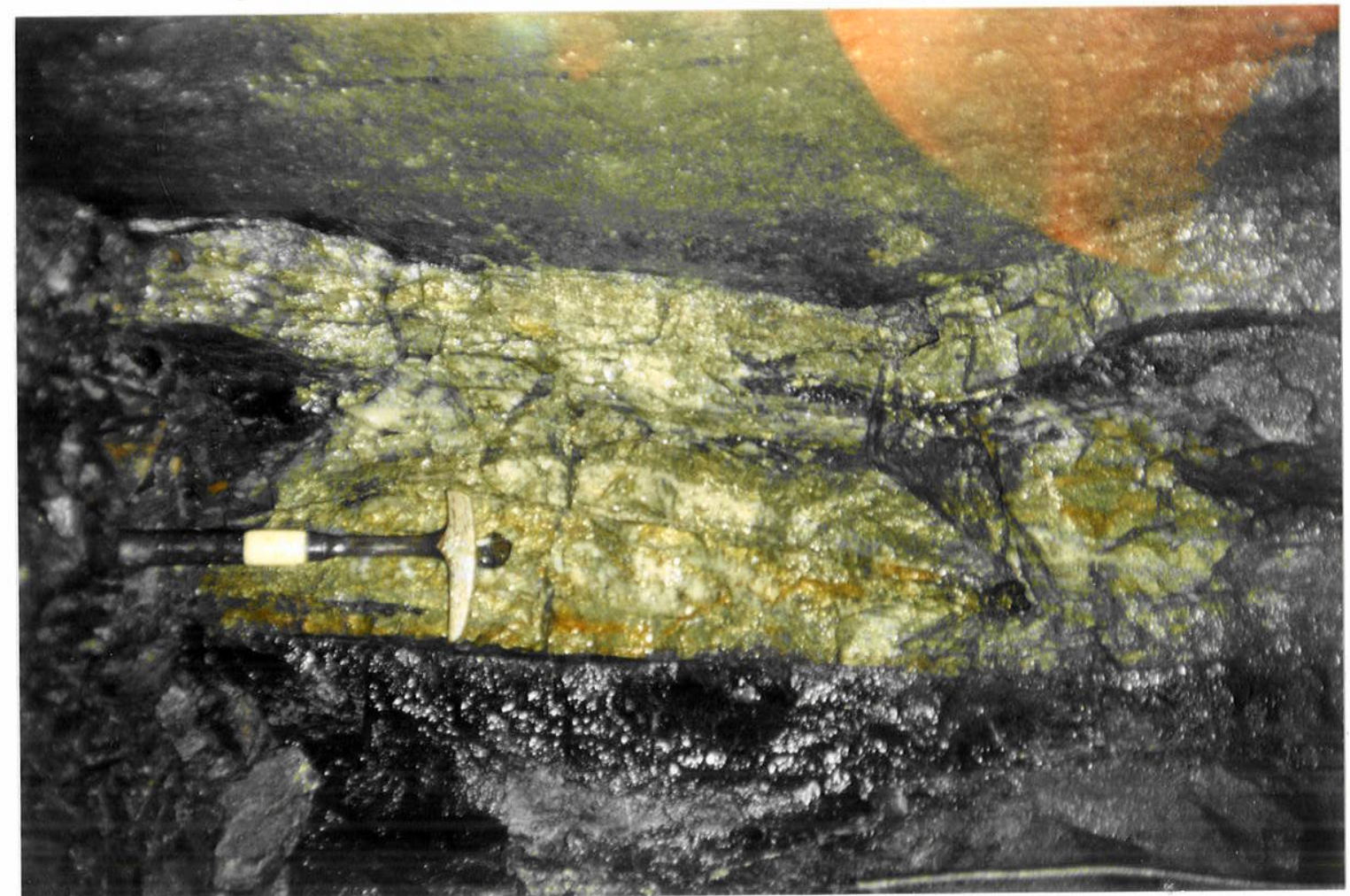

Foto 14: Detalhe do veio do Filão do Paraíba, a cerca de 70 metros de profundidade, com expressivos halos miloniticos. Foto com visada para sul. 
PA-89/a/b/c/cl - Nestas secções, é possivel observar requícios de bandamentos com leitos milimétricos de quartzo leitoso (30-40\%), alternado com niveis de sulfeto $(60-70 \%)$. Ao microcópio, verifica-se que os minerais opacos são principalmente pirita $(65-90 \%)$, calcopirita $(10-30 \%)$, magnetita $(\operatorname{Tr}-5 \%)$, calcocita $(\mathrm{Tr}-2 \%)$, bismutinita ( $\mathrm{Tr}$ ) e ouro ( $\mathrm{Tr}$ ). A pirita ocorre tanto na forma de grandes cristais subidiomórficos, em mosaico, como associada e/ou incluída na calcopirita e esfalerita, sob a forma de pequenos cristais. A calcopirita apresenta-se com formas anedrais, circundando e absorvendo os cristais de pirita, e ainda preenchendo fraturas, com inclusōes e ex-soluções lamelares de calcocita. A magnetita ocorre como grãos anedrais, associados à calcopirita, configurando bandas, com inclusões de pirita. O ouro, na forma de gotas sub-arredondadas, de cor amarelo forte, ocorre como inclusão, principalmente na pirita $e$ subordinadamente na calcopirita, com granulometria da ordem de $70-120 \mu$.

PA-89d - Pirita em grandes cristais com limites angulosos sub retangulares, evidenciando contomos hexagonais, similar à piritas geradas a partir de pirrotita, ou mesmo delineando pontos tríplices, característicos de processos de recristalização dinâmica. A calcopirita ocorre preenchendo fraturas, associadas a raros cristais de esfalerita. O ouro ocorre na forma de gotas (40 a $80 \mu)$, incluso na pirita e calcopirita.

PA-89e - Pirita em grandes cristais subidiomórficos e calcopirita xenomorfa. O ouro em micro partículas ( 45 a $60 \mu$ ) na ganga quartzosa.

As relações de contato e paragêneses minerais observadas sugerem que a precipitação de pirita foi seguida de cristalização tardia de calcopirita associada a magnetita e esfalerita.

A presença de magnetita evidência a existência de soluções submetidas a condições de média a alta fugacidade de oxigênio, conforme Seward (1984) e Roberts (1987), concorrendo para o decréscimo da atividade do enxofre reduzido, e consequente queda da solubilidade do ouro, eventualmente transportado na forma de tio-complexos. A deposição do ouro nestas condições pode ter sido incrementada pelo aumento do $\mathrm{Ph}$, em função da perda de $\mathrm{CO}_{2}$, através de reação com as encaixantes (carbonatação), ou mesmo pela redução na atividade do enxofre reduzido, devido a reação de $\mathrm{H}_{2} \mathrm{~S}$ com ferro das encaixantes básicas, para formar a pirita.

Segundo Bateman (1965), a associação pirita, magnetita, calcopirita e esfalerita indica temperaturas de deposição relativamente altas a intermediárias, provavelmente na faixa mesotermal. A presença de ex-soluções lamelares de calcocita na calcopirita evidência a atuação dos processos hidrotermais tardios, em temperaturas inferiores a $105^{\circ} \mathrm{C}$. 


\subsection{2 - Sistema Mineiro}

Compreende os veios de quartzo auríferos posicionados dentro das zonas de cisalhamentos dúcteis, apresentando formas sinuosas e frequentemente com veios de quartzo cisalhados, sacaroidais e/ou brechados. Os exemplos mais expressivos são o filão do Mineiro (PA-83), o filão do Manelão (PA-34) e o filão do Domingos (GR-07).

\subsubsection{1 - Filão do Mineiro (PA-81/83)}

Constitui um corpo filoneano com pelos menos dois veios principais sinuosos, configurando um "S", com extensão da ordem de $1.500 \mathrm{~m}$, encaixado em rochas granito-gnaíssicas com enclaves de metabásicas, em adiantado estágio de alteração. Este filão foi explorado em toda a sua extensão até uma profundidade média de 15 metros e atualmente encontra-se abandonado. A morfologia e atitude da fratura, com relação ao binário regional sinistral evidência tratar-se de uma fratura do tipo "R", sintética, de baixo ângulo, conforme a Figura 08 e o mapa geológico, em anexo.

O filão possui direção geral $\mathrm{N} 60 \mathrm{~W}$, e os veios são de quartzo leitoso bandados, com espessura ao redor de $20.30 \mathrm{~cm}$, impregnados por óxidos e hidróxidos de ferro (Tabela 12). Localmente, observa-se que os veios apresentamse desde subverticais até com mergulho da ordem de $65^{\circ}$ para nordeste, na extremidade noroeste do filão, onde verifica-se na capa, expressivo halo de coloração esverdeado, com sericita e clorita (Foto 15).

Os milonítos aflorantes na extremidade sudeste do filão do Mineiro apresentam bandas de cisalhamento centimétricas, dispostas segundo as direções N10-20E/SV e N10-15W/50NE (amostra PA-105/140) constituídas essencialmente por mica branca, opacos e cristais de corindon, envoltos por mica verde (pirofilita ?), evidenciando a formação de um marundito, resultante do expresivo enriquecimento em alumínio e potássio (Tabela 06) associado aos processos de deformação.

\subsubsection{2 - Filão do Domingos/Sebastião (GR-07)}

Constitui um expresivo corpo filoneano que se estende por cerca de 500 metros, segundo a direção geral N60W, descontínuo ou em rosário, com pelo menos três ore shoot $s$, conformando sigmóides em "Z", com espessuras na parte central da ordem de 5 metros (Figura 27).

Este filão está encaixado em rochas do tipo talco-clorita xisto, afetadas por bandas de cisalhamentos anastomosadas, centimétricas a métricas, contornando pods, dispostas sub-paralelamente ao alinhamento do filão. 


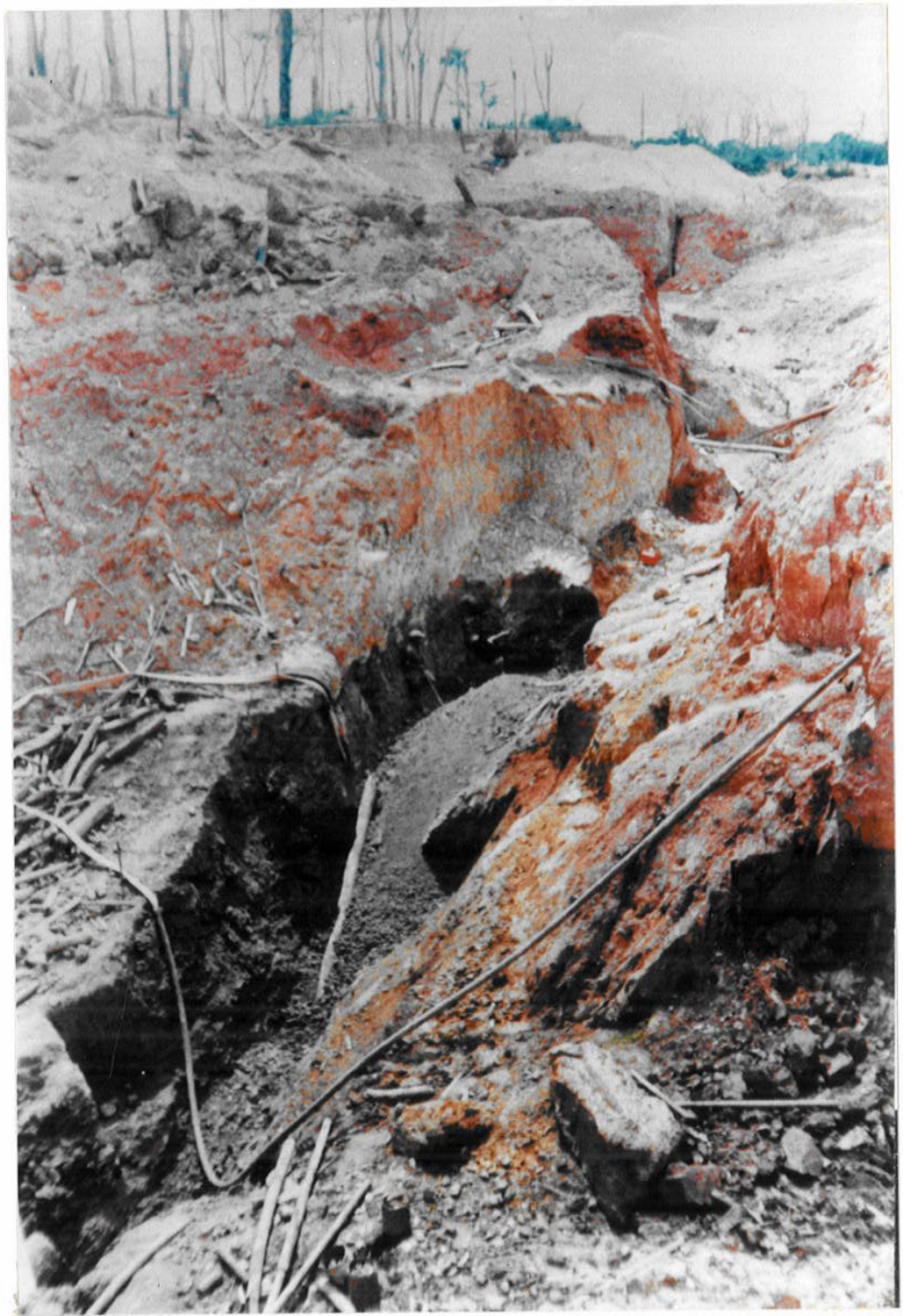

Foto 15: Aspecto do filão do mineiro, extremidade "NW", realçando a existência de halo hidrotermal do tipo sericitico-clorítico, na capa (PA-81).

Localmente, nas proximidades do veio, observa-se dobras de arrasto, fechadas a isoclinais, com eixos orientados segundo a direção N50-70W, com mergulho entre 10 a $25^{\circ}$. As estrias nos planos de cisalhamentos evidenciam uma movimentação transcorrente destral, mas a vergência dos planos axiais das dobras sugere uma componente inversa, provavelmente associada a mesma fase de deformação cisalhante. A presença de uma foliação de crenulação com atitude N80E65SE provavelmente está relacionada com o desenvolvimento da foliação "Sc", compatível com o provável binário destral.

O veio de quartzo mineralizado é esbranquiçado leitoso. localmente brechado, com 1 a $3 \%$ de malaquita e cuprita e espessura variando de poucos centímetros até 5 metros. Os teores de ouro nas encaixantes são nulos (Fire Asssay) e os teores do minério variaram entre 1,5 e 14,2 ppm (AA). 
PLANTA ESQUEMA'TICA

FILÃO DO DOMINGOS / SEBASTIÃO



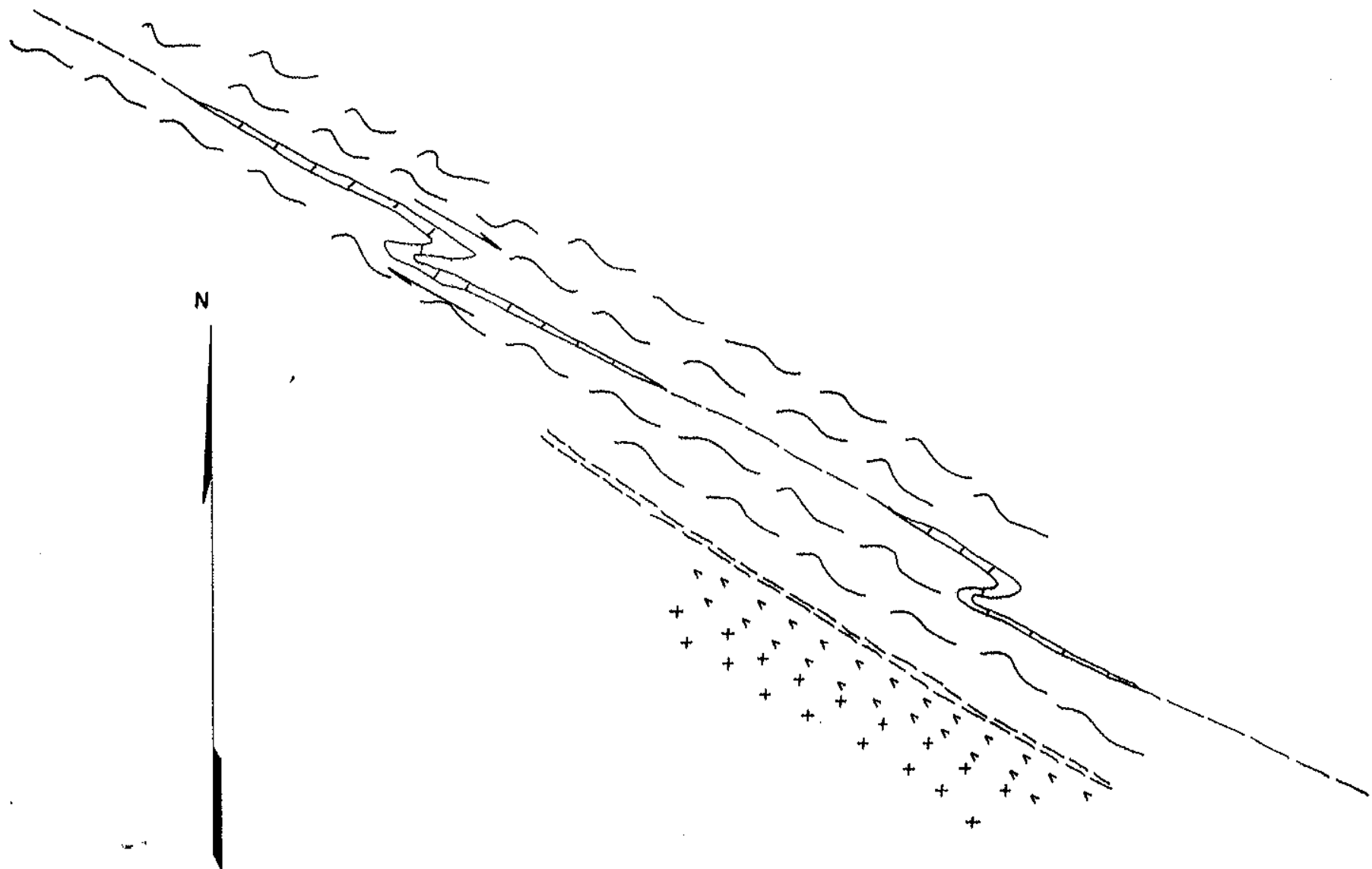

$L \quad E \quad G E N \quad$ E

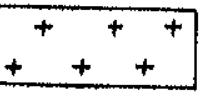

Rocho quartzo feloepotico com boläoldo ooolim.

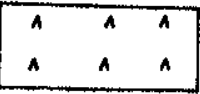

Diquos irrogulares de rocho metabásico olterodo do coloragõo acre.

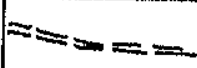

xisto cloritico com nivois onriquecidos im blotito. oxido do manqanôs.

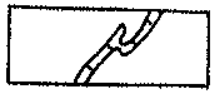

Volo de quartzo leitoso com moloquita, subverticat 


\subsection{3 - Sistema Serrinha}

Os principais veios pertencentes ao sistema Serrinha estão situados em uma zona menos deformada entre duas mega-estruturas de cisalhamento de direção geral N35-40W. No mapa geológico é possivel observar uma inflexão das estruturas, evidenciada pela disposição das cristas estruturais, alinhadas segundo a direção $\mathrm{N} 70-80 \mathrm{~W}$, subparalelas à foliação milonitica mais proeminente.

Os veios mineralizados principais estão posicionados segundo fraturas P' e R', considerando-se o binário regional sinistral (Figuras 28 e 29) e as principais feições estruturais estão listadas nas Tabelas 12 e 15 .

\subsubsection{1 - Filão da Serrinha (PA-11)}

Constitui um corpo sinuoso com atitudes variando entre N17E, na extremidade sul, a N35E, na outra extremidade, posicionado numa fratura tipo R', destral, antética ao binário principal (Figuras 28 e 29). O filão está encaixado em rochas do tipo biotita tonalitos, gnáissicos, com níveis de metabásicas cisalhadas, alinhadas na direção $\mathrm{N} 60-70 \mathrm{~W}$, e apófises graníticas dispostas preferencialmente segundo as direções E-W e N25E. Nas proximidades do corpo ocorrem blocos de rochas meta-ultrabásicas (PA-101), constituídas por clinopiroxênio e plagioclásio, silicificadas e dobradas (Microfoto 3 e Foto 3).

Quando da lavra a céu aberto, o filão constituía em um veio de quartzo brechado, com ouro visivel associado a minerais de alteração como goetita, hematita, pseudomorfos de carbonatos e relictos de pirita (Foto 16). Localmente, verificou-se bolsões de pirita subidiomórfica em processo de oxidação, com inclusões microscópicas de calcopirita transformando-se em calcocita. O minério é do tipo veio de quartzo brechado, alterado, com os fragmentos de quartzo sacaroidal cimentados por óxidos amorfos de ferro. Observa-se localmente, nas fraturas preenchidas por óxidos de ferro, texturas secundárias tipo casa de abelha e box works. O ouro ocorre tanto na forma de micro pepitas (500-1100 $\mu$ ) preenchendo fraturas como dentro dos grãos de quartzo. Nos grãos reliquiares de pirita, observam-se inclusões de calcopirita.

Um poço recém-aberto que acessou o filão a uma profundidade de cerca de 28 metros da superficie atual, expôs o veio mineralizado, conforme croqui apresentado na planta esquemática da Figura 30. Na galeria aberta neste poço verificou-se que o veio está encaixado em gnaisses tonalíticos com bandamento grosseiro, apresentando-se com foliação metamórfica N15E 45SE e afetado, nas proximidades do filão, por diques de rochas metabásicas e injeções graníticas, localmente pegmatíticas.

$O$ veio apresenta-se com espessura de $30 \mathrm{~cm}$, sendo do tipo leitoso, bandado, com leitos piritosos de 1 a $3 \mathrm{~cm}$ de largura, e atitude N25E 70NW. O halo é do tipo sericítico e clorítico, com feições miloníticas, e espessuras da ordem de $0,5 \mathrm{~m}$, disposto de ambos os lados do veio. Localmente o halo ocorre em contato 
DISPOSICÃ̃O RELATIVA DOS ELEMENTOS

ESTRUTURAIS NO SISTEMA SERRINHA

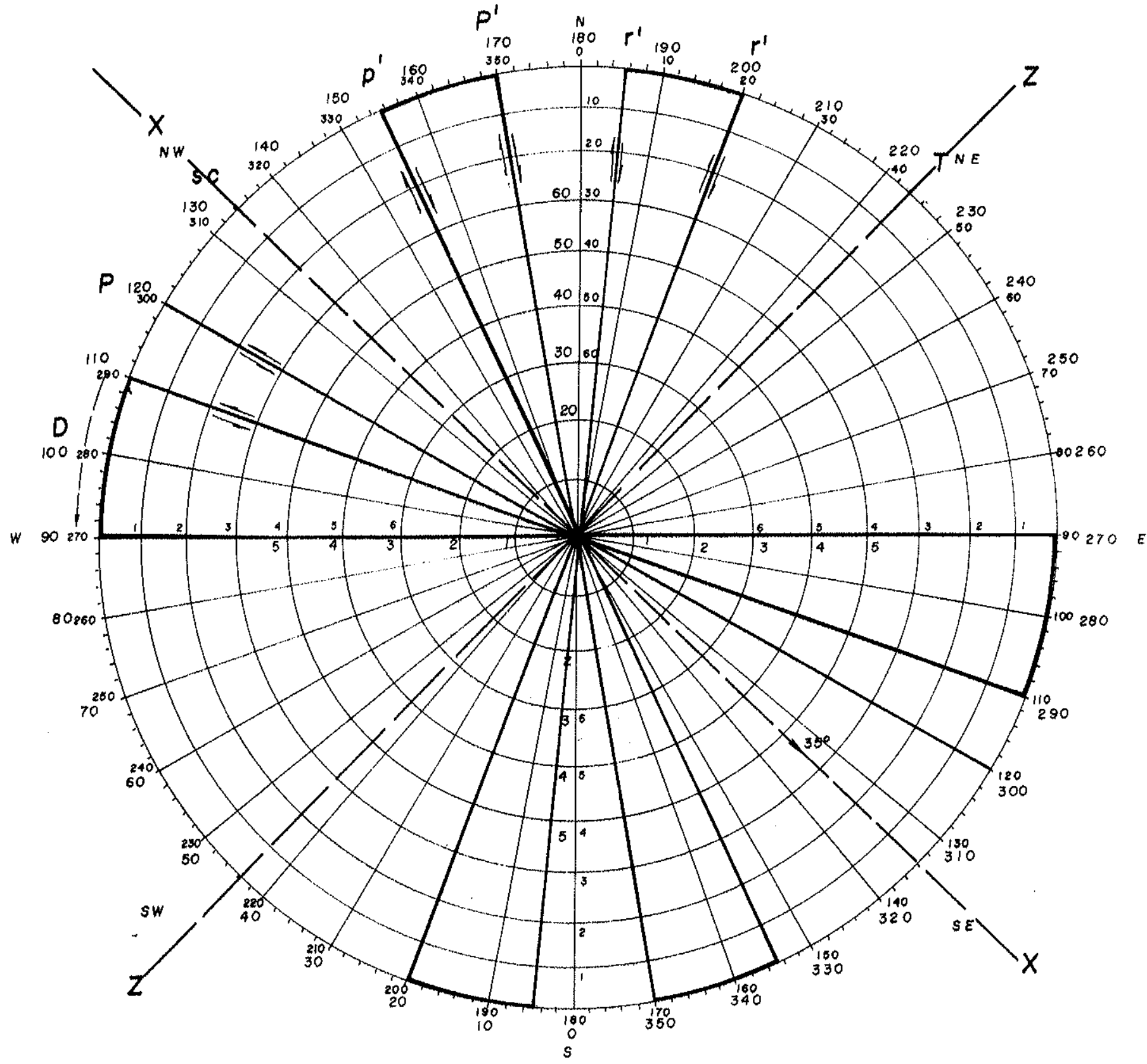

DIAGRAMA POLAR

LINEACOOES/SUPERFI'CIES

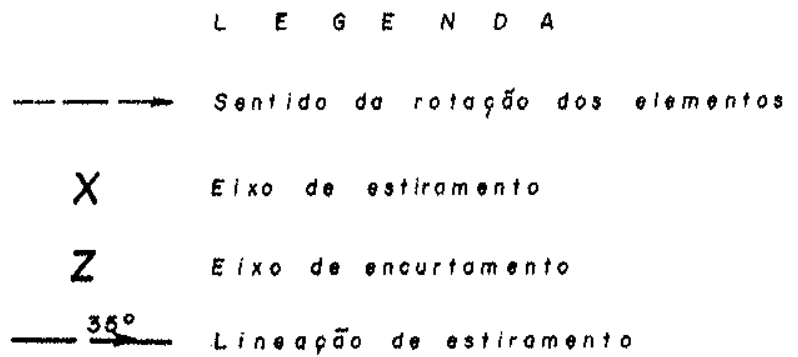

Fig. -28 


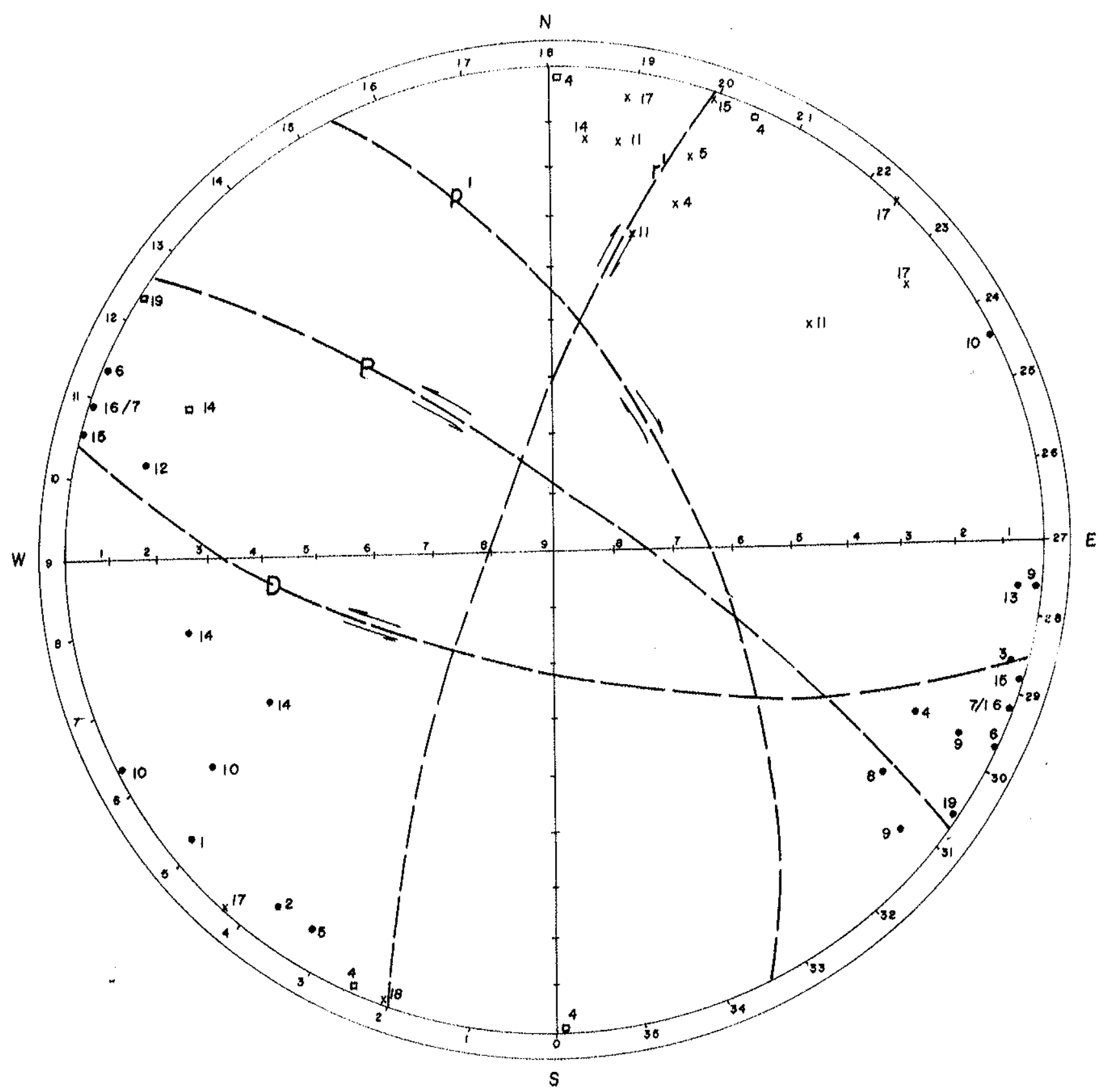

DIAGRAMA DE SCHMIDT-LAMBERT

LE GENDA

\footnotetext{
- Polor de veios

$x$ Polos de follogão mllonitico

- Polos de diques opofises

Eroturo $D \cong N 75 W 70 \mathrm{SW}$

FroturaP N $=N 5 W 80 \mathrm{NE}$

Frotura $p^{\prime} \simeq N 25 W 65 N E$

Froturop' $\simeq \mathrm{N} 20 \mathrm{E} 80 \mathrm{NW}$
}

Obs. As atituder estäo relocionodas na tabela is

Fig. -29 
PLANTA ESQUEMA'TICA

FIL $\tilde{O} O$ DA SERRINHA

ESCALA
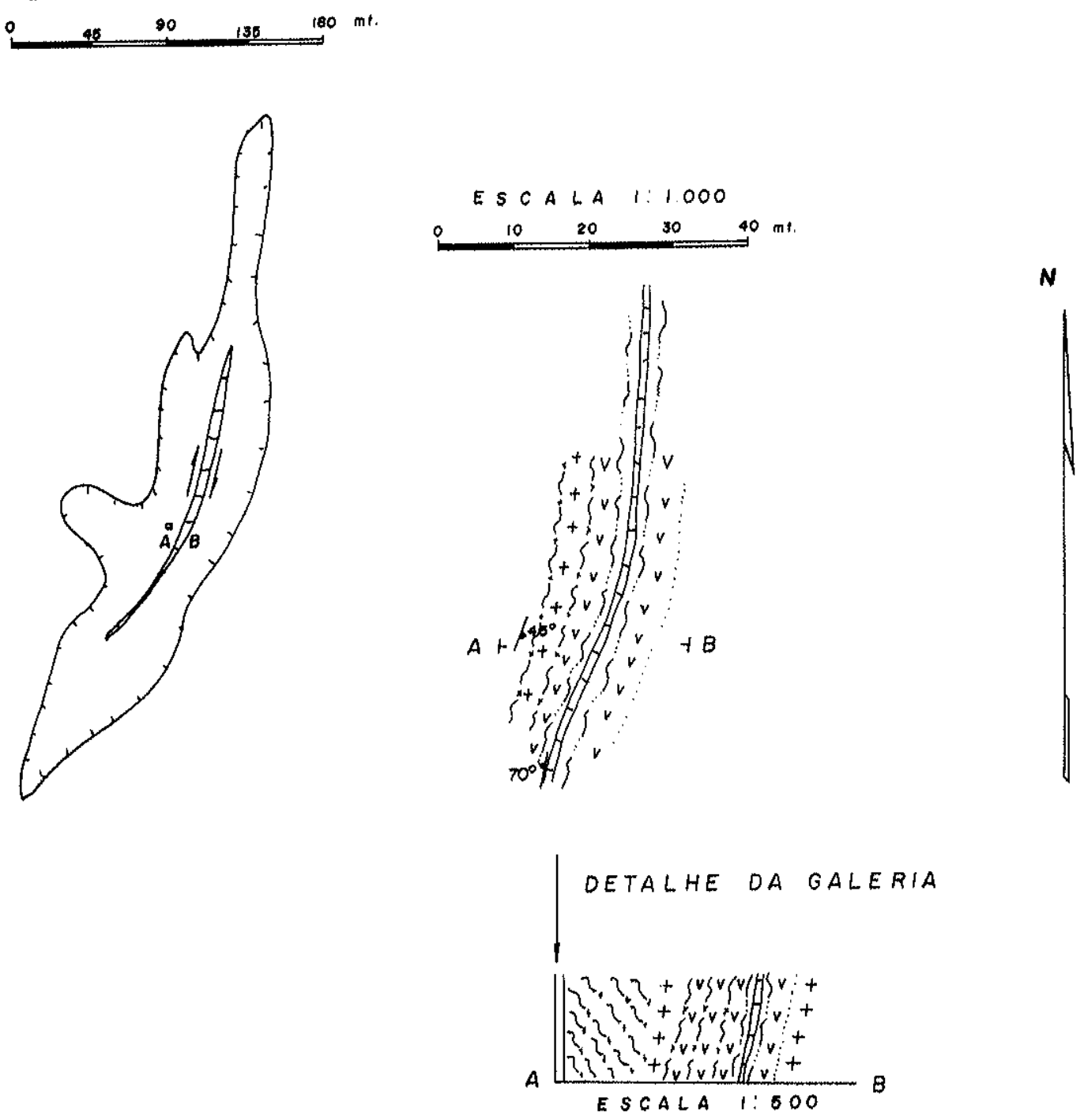

b E E G E N

- POQO

Follaçáo motomórtico


Atifude de velo

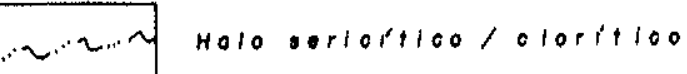

[............... zono de 111 aleloaparo oom venulagóos

Voio de quartzo loitoso, bondodo oom pirtio






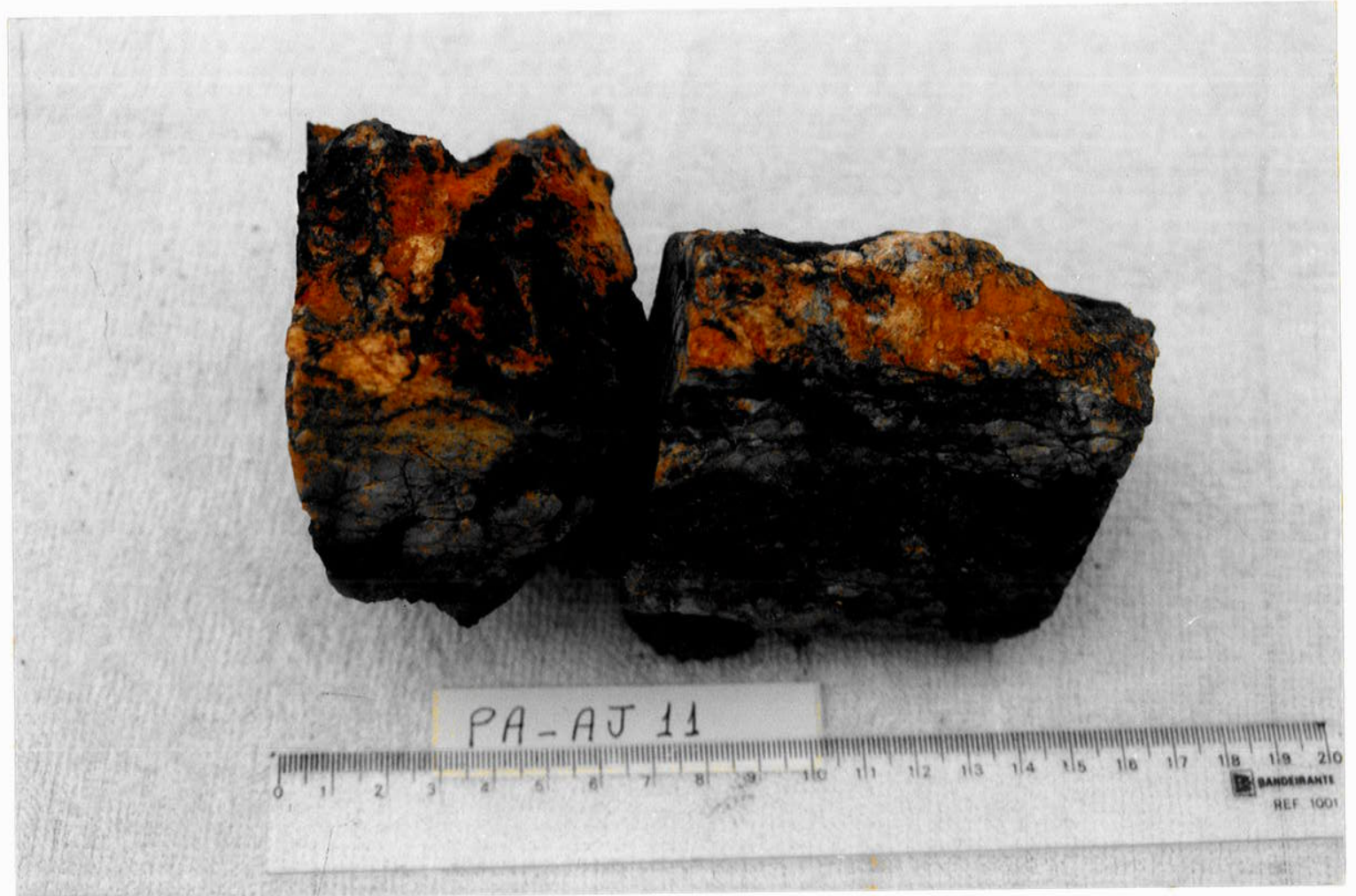

Foto 16: Minério brechado e oxidado do Filão da Serrinha, com bolsões de pirita, pseudomorfos de carbonatos e micro pepitas de ouro (PA-11).

brusco com o veio, não sendo observados restos nem fatias das rochas encaixantes ou halos englobados pelo veio.

Associadas às injeções graníticas, verifica-se a presença de zonas de silicificação e venulações piritosas, com potassificação das encaixantes tonalíticas.

\subsubsection{2 - Filão do Melado (PA-124/127)}

Constitui um corpo sinuoso, configurando um suave "Z", com atitude da ordem de N05E/80NW, extremidade sul e N25E/80NW na outra extremidade, está, disposto ao longo de uma fratura R', destral, antética ao binário sinistral regional, conforme (Figura 08), seção esquemática (Figura 31) e diagramas estruturais (Figuras 28 e 29).

O filão está encaixado em rochas do tipo biotita gnaisses tonalíticos a granodioríticos, com enclaves de rochas metabásicas estirados. Nas proximidades do corpo observa-se intensos processos de potassificação das encaixantes, com neogeração do feldspato potássico e fraturas preenchidas por pirita, calcopirita e bornita, provavelmente associadas às injeções graníticas, localmente pegmatíticas, que afetam o embasamento gnaíssico. 
FILÃO DO MELADO

ESCALA 1.2000
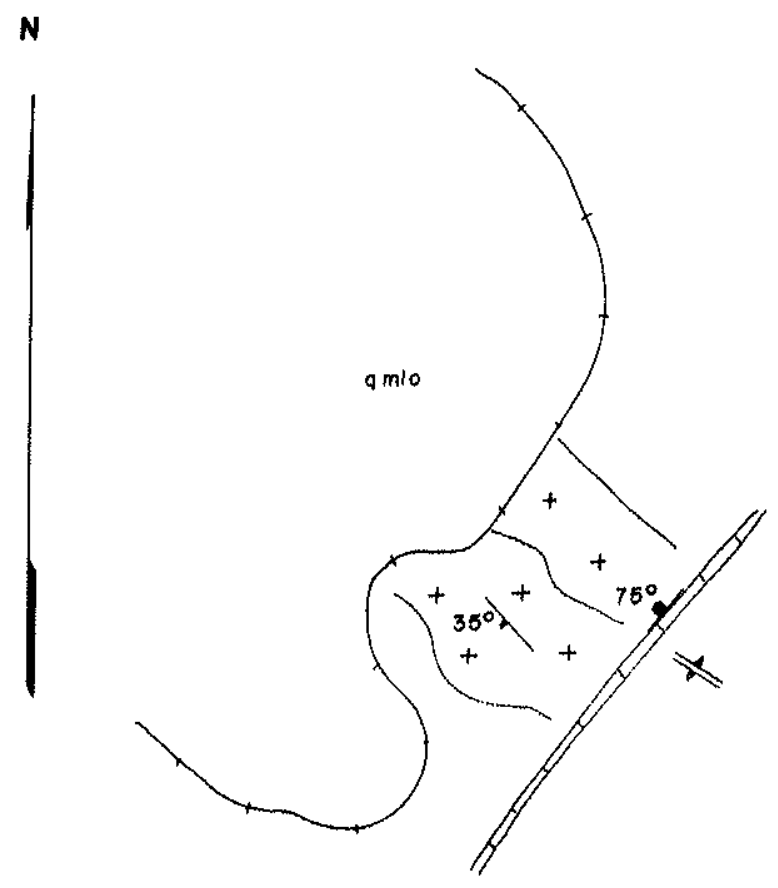

L. E G E N D A


Fig. -31
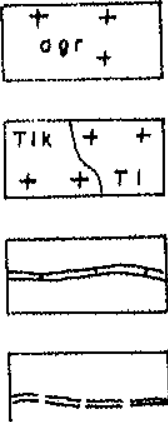

amio

$\mathbf{p m l 0}$

Apofllos de olcolforontos, overmolhodos, portirlticos

Tonalitos

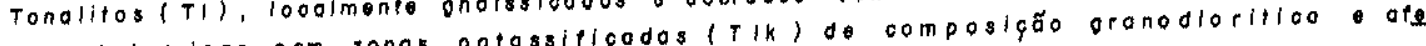
do metabasicas com zonas potossits

Velo de quartzo toitoso, bandado, sulfotodo com piritos, colcopirito bornito.

Holo de alterogdo no copa, zono de propilitizogóo interna a umo zonado silicifigoQ õo mas externa.

contorno oproximado de cristas ostruturais, quortzo milonitos.

Cristos sustentados per rochas quartzo milonticos, ossoolodo a izonas de cisa. ihomontos repionois. 
$O$ veio aflorante na extremidade sul apresenta-se pouco alterado, com espessura de cerca de $35 \mathrm{~cm}$, encaixado em rochas tonalíticas frescas, com halo sericítico pouco desenvolvido e sem evidencias de cisalhamento. $O$ veio é do tipo quartzo leitoso com sulfeto disseminado (1 a 3\%), representado basicamente por pirita, calcopirita e bornita.

Na extremidade norte, tanto o veio como as encaixantes encontramse extremamente alterados. O veio, com ouro visível e espessura em torno de 25 $\mathrm{cm}$, apresenta expressivo halo de alteração na capa, conforme representação na Figura 31 e Foto 17.

Aparentemente, o veio está mais enriquecido na porção central próximo ao ponto de inflexão do filão, coincidindo com a zona de distensão da estrutura.

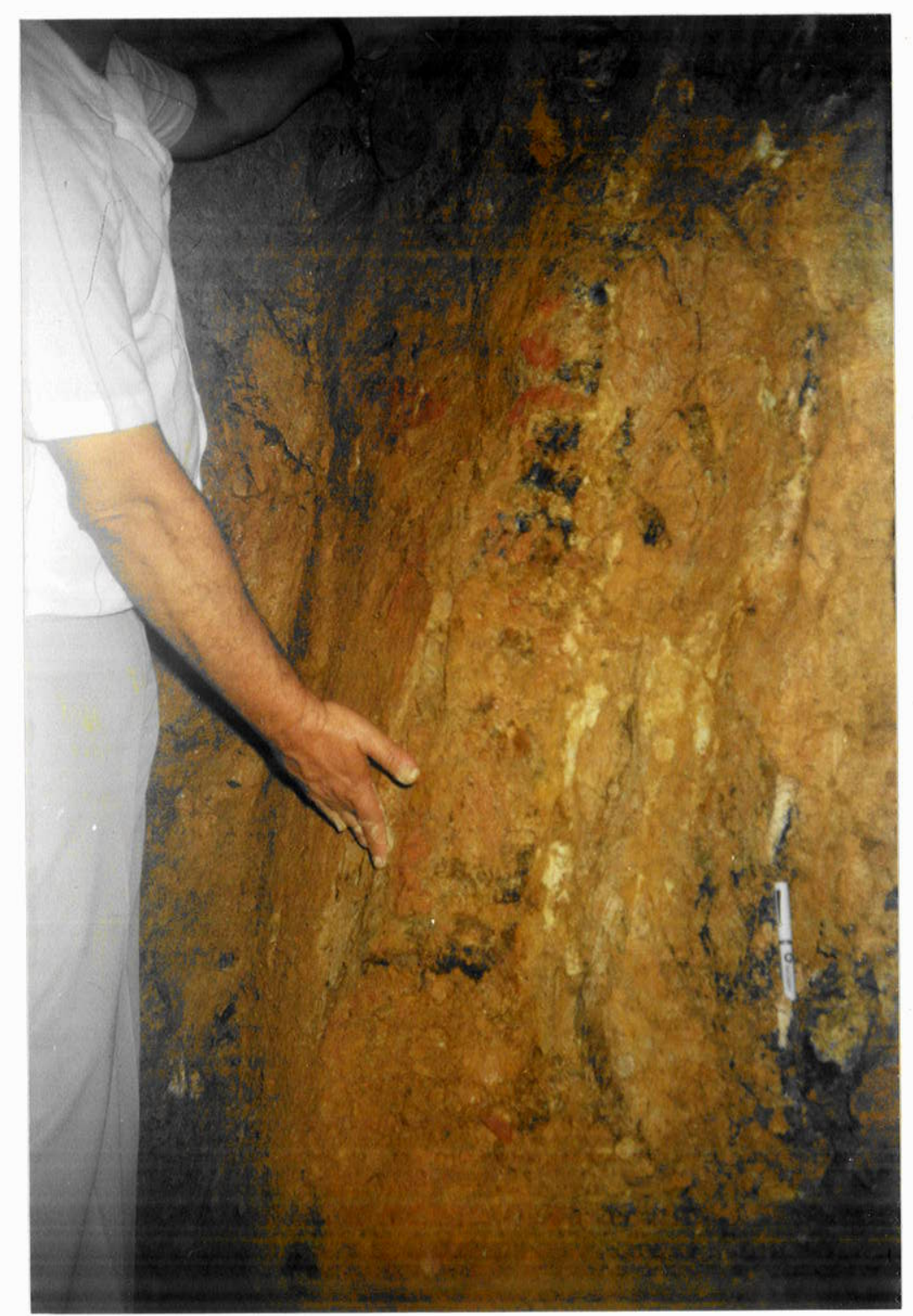

Foto 17: Veio de quartzo mineralizado do Filão do Melado, galeria aberta no rumo NE, a cerca de $15 \mathrm{~m}$ da boca do poço. (PA - 124). 


\subsubsection{3 - Filão do Roberto Gaúcho (PA-158/159)}

Constitui um corpo filoneano sinuoso, com atitudes da ordem de N10W/65NE na extremidade sul e N25W/60NE, na outra extremidade. O filão está posicionado provavelmente em uma fratura do tipo " $\mathrm{P}^{\prime}$ ", antética ao binário principal sinistral (Figuras 08, 28, 29 e 32).

O corpo se estende por mais de 450 metros, e foi explorado de forma mais acentuada em 5 pontos, onde a garimpagem evoluiu até profundidades da ordem de 30 metros, que muito provavelmente contituem ore shoots, evidenciando uma morfologia em rosário.

A encaixante regional está representada por granodioritos e tonalitos gnaíssicos de coloração cinza, com enclaves de metabásicas, foliadas e com resquícios de bandamento, pertencentes a unidade Granitóides Arqueanos.

Localmente estas rochas apresentam-se alteradas, com alternância de leitos escuros micáceos e leitos esbranquiçados, caolinizados, com a foliação disposta segundo a direção N60W/70NE.

Níveis e intercalações de rochas metabásicas ocorrem alinhadas segundo o rumo W-NW. Diques de diabásio estão dispostos segundo direção N35$40 \mathrm{E}$, compativeis com a direção das fraturas extensionais, tipo "T". Microgranitos e quartzolitos também afetam estes granitóides nas adjacências do corpo filoneano (Figura 32).

Na extremidade norte do corpo afloram, na capa, rochas graníticas rósea-esverdeadas, com epidotização pervasiva.

$O$ filão está balizado por bandas de cisalhamento discretas, com atitudes N10W/70NE e N10E/70SE, e por inúmeras superficies estriadas, anastomosadas, com atitudes N25SE/SV, N15E/65SE, N20W/65NE, evidenciando uma movimentação predominantemente trancorrente destral.

O minério é do tipo veio de quartzo leitoso, bastante alterado, com boxworks e pseudomorfos de sulfetos, localmente apresentando bolsões de pirita.

\subsection{4 - Sistema Flor da Serra}

Este sistema está muito bem representado na região compreendida entre as localidades de Peteca e Flor da Serra conforme pode ser visualizado no mapa geológico e Tabelas 11 e 16.

Destacam-se neste sistema dois padrões de fraturamento preferenciais preenchidos por veios de quartzo auriferos, um com direção geral N70-80W, balizado por possantes estruturas miloníticas, e o outro com direção em torno de N10W, com feições de cisalhamento discretas e teores de ouro mais expressivos. 
PLANTA ESQUEMA'TICA

FILÃO DO GAÚCHO (PA 158/159)

ESCALA 1:2000

$\begin{array}{lllllll}0 & 20 & 40 & 60 & 60 & 100 \quad 120 & \mathrm{mt} .\end{array}$

$L \quad E \quad G \quad E \quad N \quad O \quad A$

Tho Alltude de diques basicos

$75^{\circ}$ Foliagão metamórtico

T50 Atilude de voio de quortzo

$==$ Halo do alteropõo sericitico eloritico.
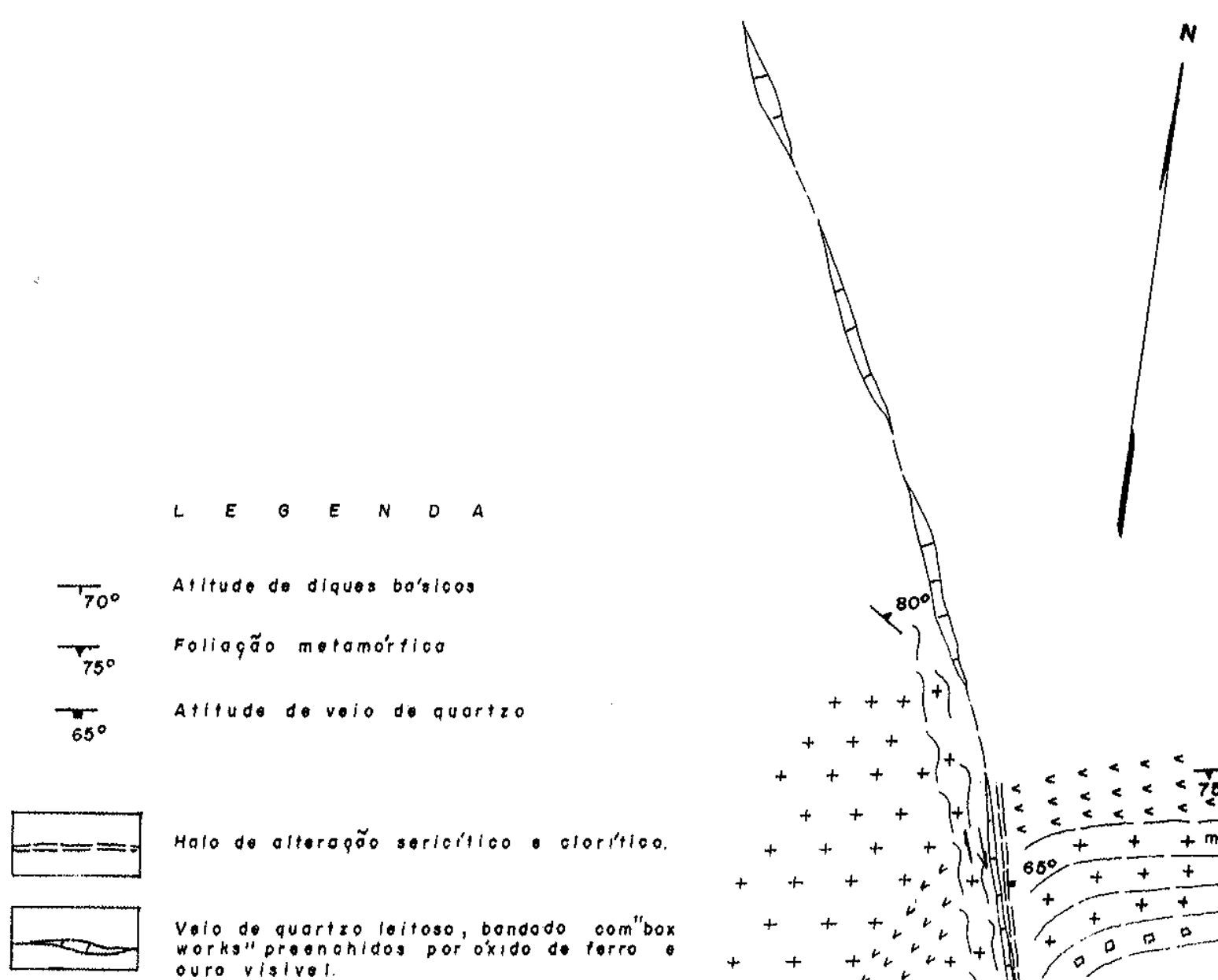

Vio de quartzo loitoso, bondodo com"box works" proonahidos por oxido de torro ouro visivel.

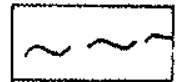

zonas de cataolase discretas afotanto prinotpolmento os molagronodioritosim N O5W $60 \mathrm{NE}$ - ixodo osiria Nor w/s

$\square 000$

Diques de quortzolitos de oranulometria fina a modio oom tolospotos coolinizodos
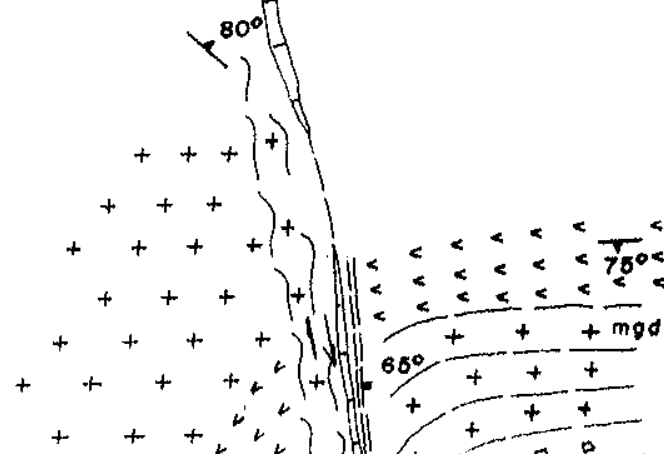

$+++^{2}+r^{2}+$



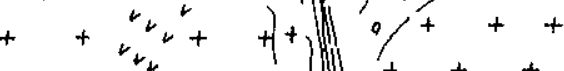
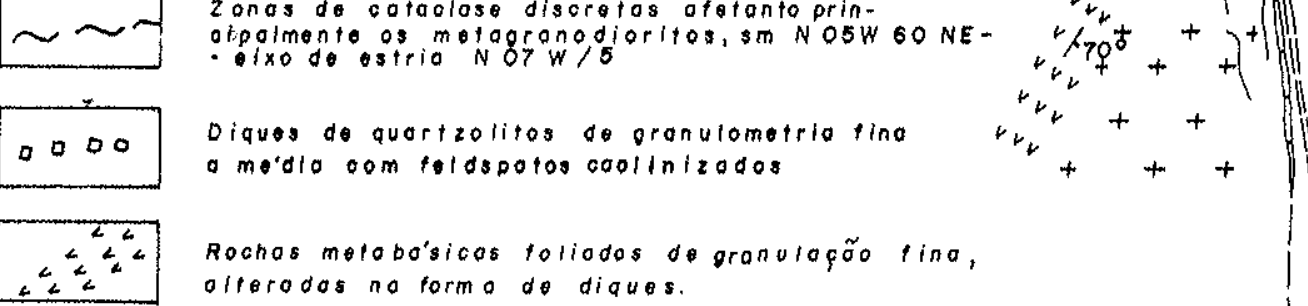

Rochas melobo'sicas toliodos de granulacão tina, olferodas na formo do diques.

Metagranodiorito tonalito com bandamento gnaissico

o enclaves de rochos metoba'sicas. 


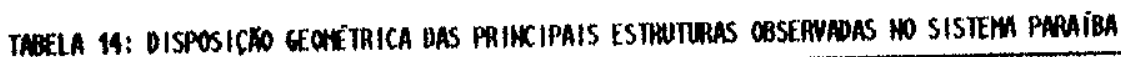

\begin{tabular}{|c|c|}
\hline 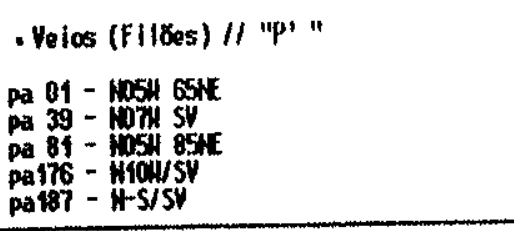 & $\begin{array}{l}\text { Superficies estriadas } \\
\text { Wow/SV (Destro) Estria Nfot } 35^{\circ} \\
\text { Ejoo de dobras de arrasto } \\
150-6040^{\circ}\end{array}$ \\
\hline 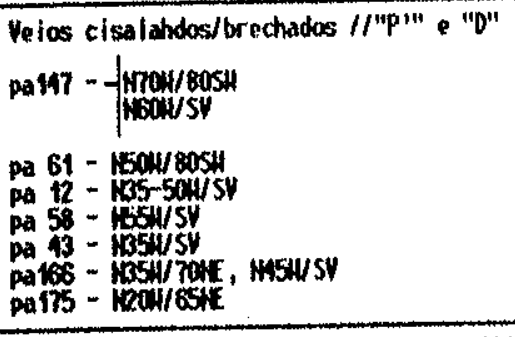 & 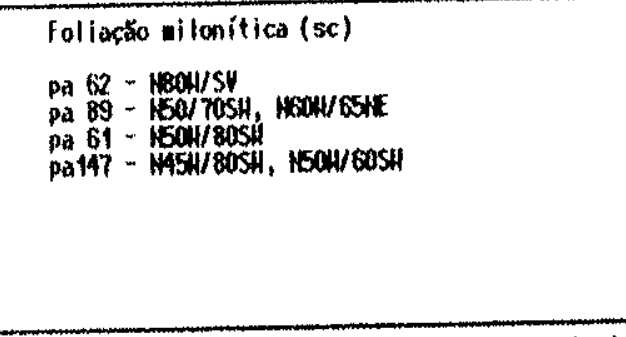 \\
\hline 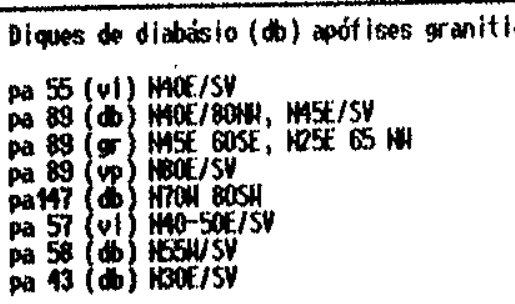 & $s(g r)$, venulactes $(v))$ e veios pegmatiticos $(\mathrm{w})$ \\
\hline
\end{tabular}

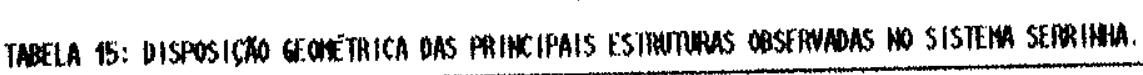

\begin{tabular}{|c|c|}
\hline \multirow{2}{*}{\multicolumn{2}{|c|}{ 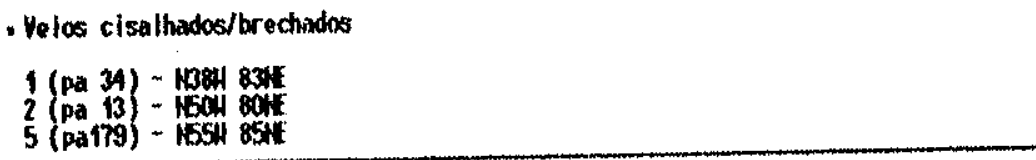 }} \\
\hline & \\
\hline \multicolumn{2}{|l|}{ - Veios de quartzo leitoso (filzes) } \\
\hline 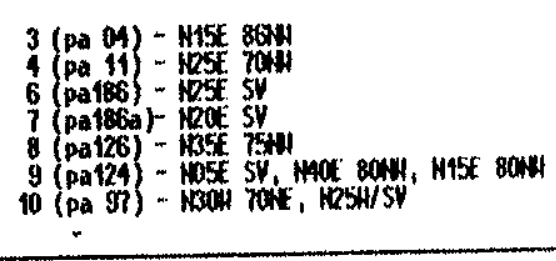 &  \\
\hline \multicolumn{2}{|l|}{+ Foliaclio milonitica } \\
\hline 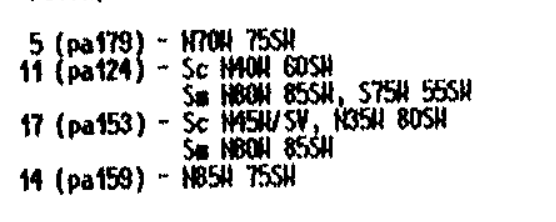 & 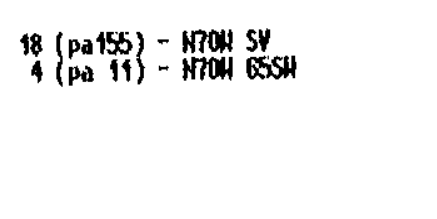 \\
\hline 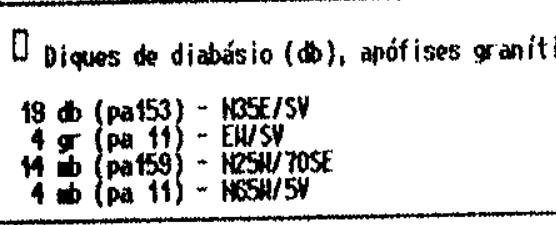 & (g) e mota hásicas (b) \\
\hline
\end{tabular}

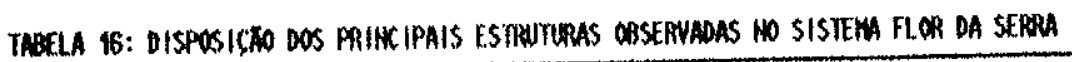

\begin{tabular}{|c|c|c|c|c|}
\hline \multicolumn{4}{|c|}{ - Veio quartzo leitoso/ cisalhado } & \multirow{2}{*}{ 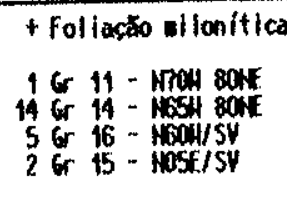 } \\
\hline 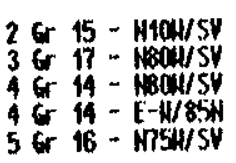 & 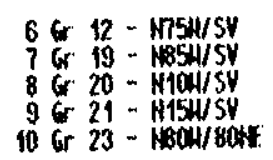 & 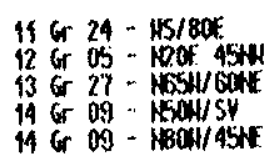 & 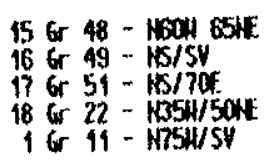 & \\
\hline
\end{tabular}


Dentro da configuração proposta, considerando-se os binários regionais sub paralelos à borda sul do Graben do Cachimbo, as fraturas de cisalhamento com direção N70-80 W estão posicionadas segundo fraturas tipo "P" ou "D", enquanto os veios formados preenchendo fraturas com direção N10W, são do tipo " $\mathrm{P}$ ", conforme representado na Figura 33.

\subsubsection{1 - Filão do Olerindo (GR-14)}

Constitui um corpo filoneano, com extensão da ordem de 500 metros, disposto segundo uma fratura tipo "D", com direção geral N80W, subvertical e balizado por possantes estruturas miloníticas, conforme representado na Figura 34.

O filão está encaixado em rochas gnaíssicas finamente bandadas que se apresentam nas proximidades do filão, como um xisto milonítico quartzofeldspatico, com granadas milimétricas disseminadas. Rochas metabásicas bastante alteradas e cisalhadas cortam os gnaisses e constituem encaixantes do filão na zona mais enriquecida onde foi aberto um poço. Localmente observam-se possantes diques de riolito, dispostos segundo a direção $\mathrm{N} 40 \mathrm{E}$, provavelmente dispostos ao longo de fraturas extensionais do tipo "T". Andesitos pórfiros cinza-escuros, granitos avermelhados e zonas de silificação também ocorrem nas proximidades do filão (Figura 34).

O minério do veio é do tipo quartzo leitoso, com cor cinzaavermelhada devido a presença de disseminações de óxido de ferro (Foto 18).

\subsubsection{2 - Filão do Geraldo (GR-16)}

Constitue um corpo filoneano com extensão aflorante da ordem de 150 metros, disposto segundo uma fratura tipo "P", com direção N75W/SV. Está encaixado em gnaisses com bandamento sub milimétrico, localmente cisalhados e com desenvolvimento de expressivo halo sericitico.

O minério é do tipo de veio de quartzo, bandado, sulfetado, com pirita, calcopirita, calcocita e bornita; nos fragmentos mais alterados observa-se ainda, malaquita, cuprita e óxido de ferro.

A estrutura bandada do veio (Foto 19), com linhas de crescimento evidenciadas por faixas de inclusões, absorvidas durante a formação do veio, é característica do processo de crack-seal, típico mecanismo de formação de veios, através de episódios sucessivos de abertura e preenchimento de fraturas.

\subsubsection{3 - Filão do Naiuam (GR - 05)}

Constitui um corpo mineralizado com atitude N20E/30 a $65 \mathrm{NW}$, extenção da ordem de 300 metros e espessura média em torno de $30 \mathrm{~cm}$. 
DISPOSICÃO RELATIVA DOS ELEMENTOS

ESTRUTURAIS NO SISTEMA FLÔR DA SERRA
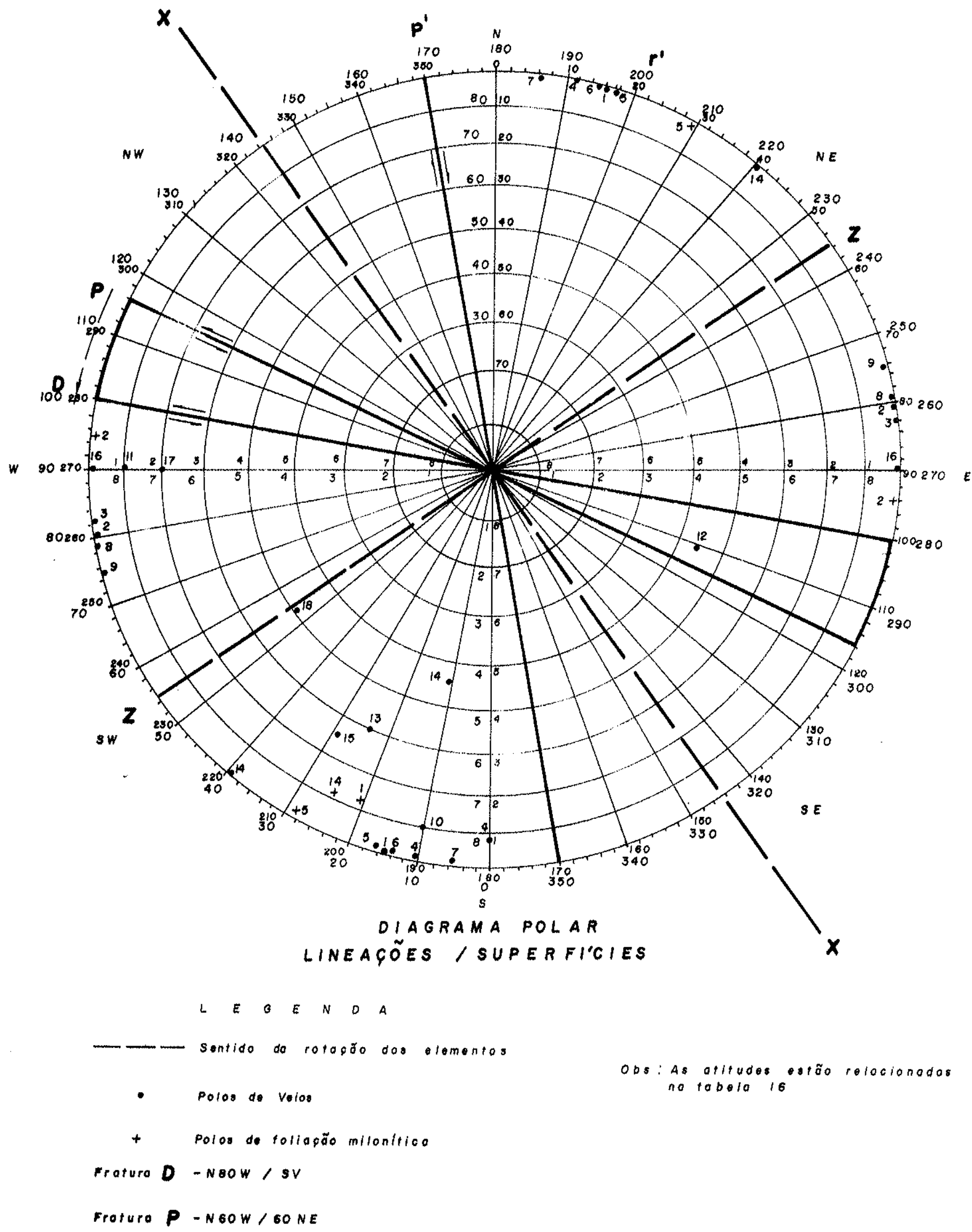

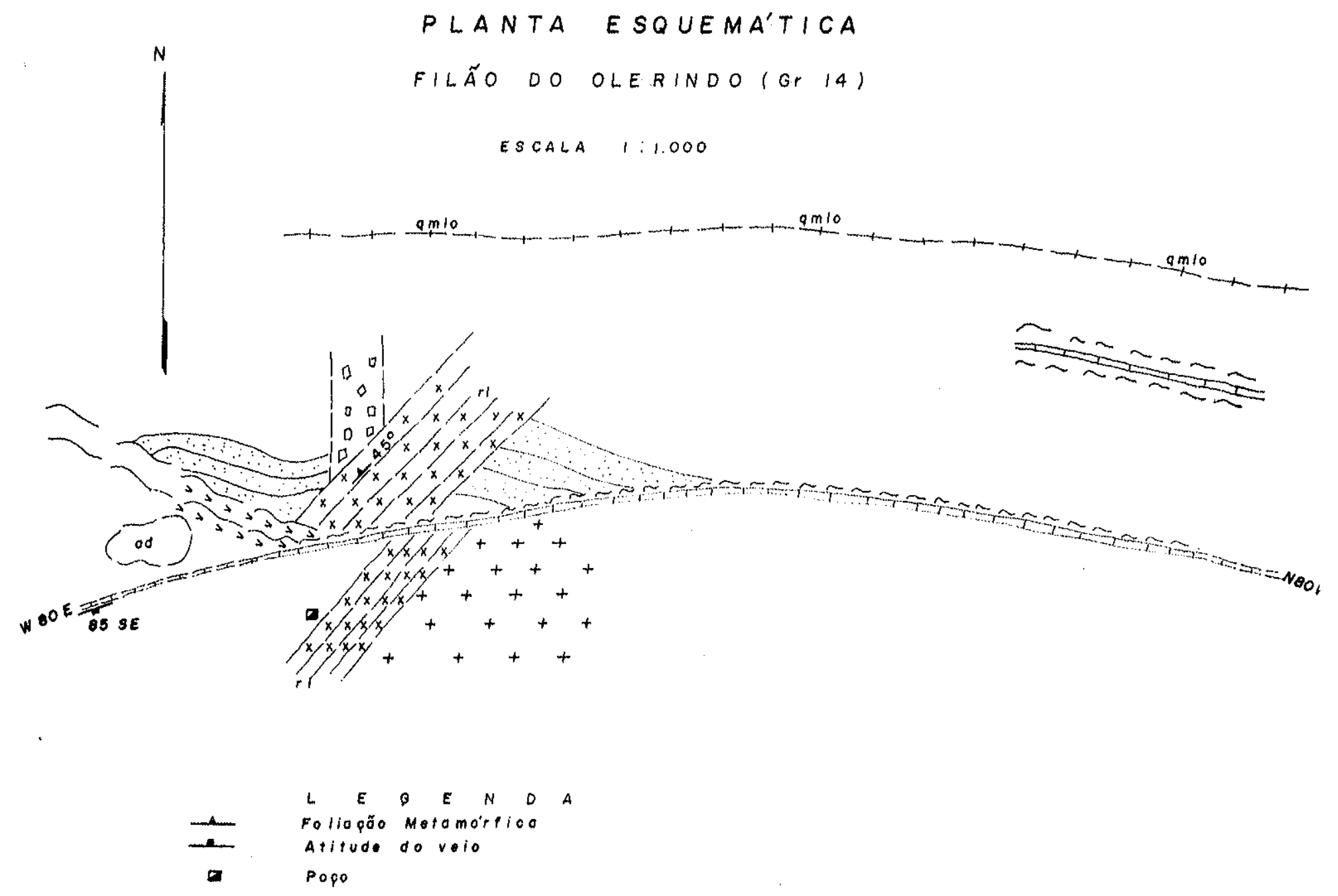

Crista sustontada por rocha quartzo-miloniticos.

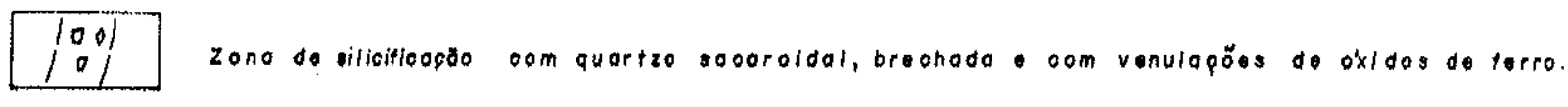

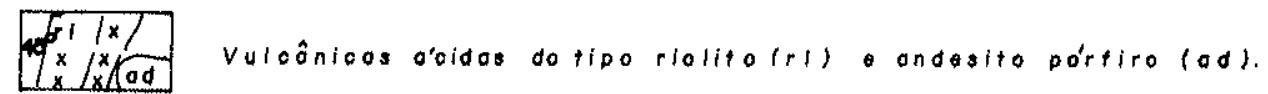


Metabasica de granalometria tina, alterada o cisalhada com clarita, hornblenda, olaoroclasio a quartzo, corpos no formo de diques.

$\sim \sim$

zona do cataclose olou milonitizaǵto

Rocho gnoissico com bandomento milimetriop, quortzo teldspatioo com cristois milimetrioos do oranada 


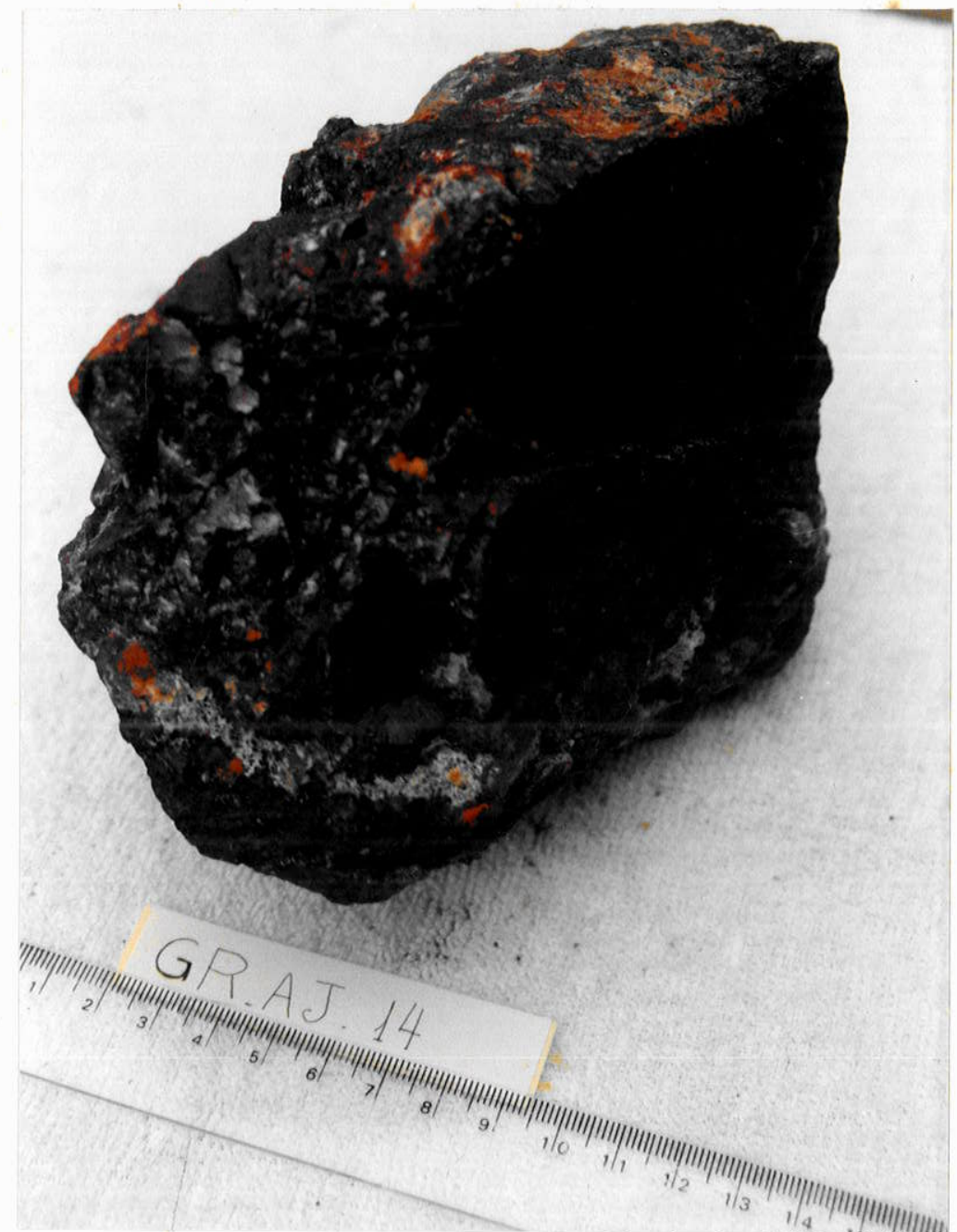

Foto 18: Veio quartzo aurífero do filão do Olerindo (GR-14).

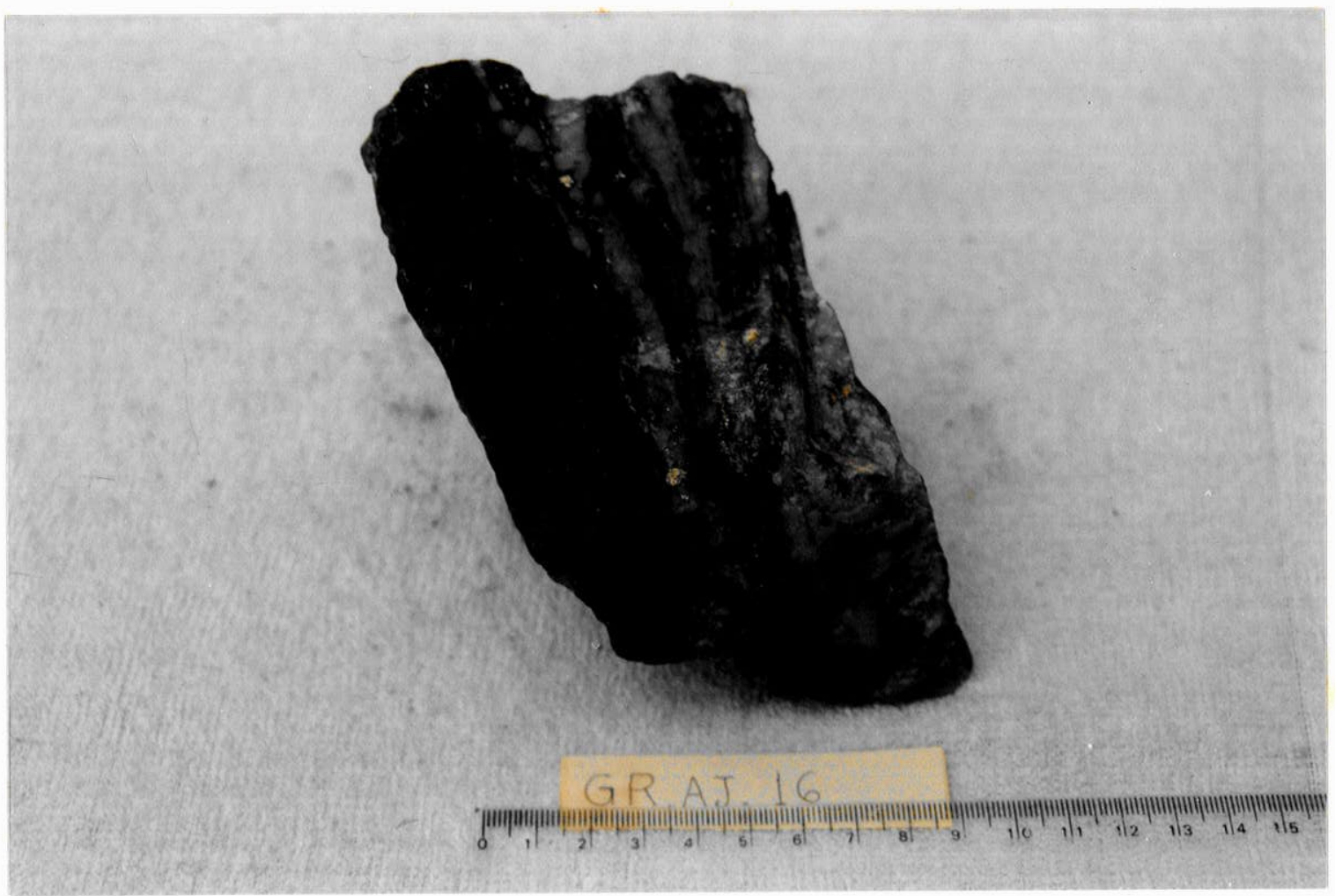

Foto 19: Veio bandado sulfetado, com evidências de crescimento por crack-seal, filão do Geraldo (GR-16). 
A inexistência de cataclase nas rochas encaixantes e a presença de enxames de diques de diabásio, sub-paralelos à direção do filão, sugere que se trata de uma fratura extensional, de natureza lística, com mergulho da ordem de $65^{\circ}$ na superficie, chegando a $30^{\circ}$, na profundidades de 25 metros.

As encaixantes observadas principalmente na lapa do veio são dioritos e biotita tonalitos gnaissificados com enclaves ovalados de metabásicas correlacionáveis à unidade Granitóides Arqueanos, conforme representação esquematizada na Figura 35. Nas proximidades do veio essas rochas apresentam-se potassificadas, com neogeração de megacristais de feldspato potássico, provavelmente devido à interação com fluidos oriundos das injeções graniticas que afetam as sequências, e inclusive constituem as encaixantes na lapa do veio.

O minério é do tipo veio de quartzo leitoso, poroso, com grande densidade de cavidades, certamente resultantes da lixiviação de sulfetos e carbonatos, caracterizando uma textura tipo boxwork. O halo primário está representado por uma rocha muito alterada de cor ocre e natureza argilosa, o que sugere estar associado a processos de carbonatação.

A existência no veio mineralizado de pirita (10-20\%) associada a hematita (especularita), (1-5\%) evidência que os fluidos mineralizados apresentam alta fugacidade de oxigênio, conforme Seward (1984), e que a deposição se deu em temperaturas relativamente altas, (cf. Bateman 1965), compativeis provavelmente com as condições hipotermais. É importante realçar no caso uma eventual fonte granitica para os fluidos mineralizados, uma vez que este é dos raros filões onde rochas do tipo álcali granitos ocorrem em contato direto com o veio.

Ao microscópico oberva-se trilhas de micro pepitas de ouro $(10-15$ $\mu)$ na ganga silicosa.

\section{1 .5 - Sistemas Indiferenciados}

Compreendem vários outros filões, importantes na produção de ouro na região, provavelmente condicionados a fraturas vinculadas às estruturas regionais de cisalhamento, porém não constituindo sistemas persistentes, que viessem a configurar um padrão preferencial de fraturamento.

Neste contexto, exitem inúmeros filões mapeados nas regiões garimpeiras conhecidas como Lampião (PA 167/168), Zé Déco (PA 78/79), Gavião (PA 146/171/177), Aragão (GR 18/30/31/32/33/ 41), Br 080 (MP 02) e vários outros fora da área de abrangência deste trabalho. Dentre os filões citados, o da Sede (MP 02), Cubu (GR 32), Herédio (PA 79) e Zé Déco (PA 78) são os mais interessantes quanto ao potencial metalogenético.

$O$ Filão da Sede (MP-02), tem direção geral N60W/85NE, extensão da ordem de 500 metros, espessura média de $25 \mathrm{~cm}$, e está alojado provavelmente em uma fratura de tipo "P", sintética, subordinada a binários regionais sinistrais. 


\section{PLANTA ESQUEMA'TICA}

FILÃO DO NAIURAM (Gr5)

$$
\text { ESCALA } 1: 2000
$$

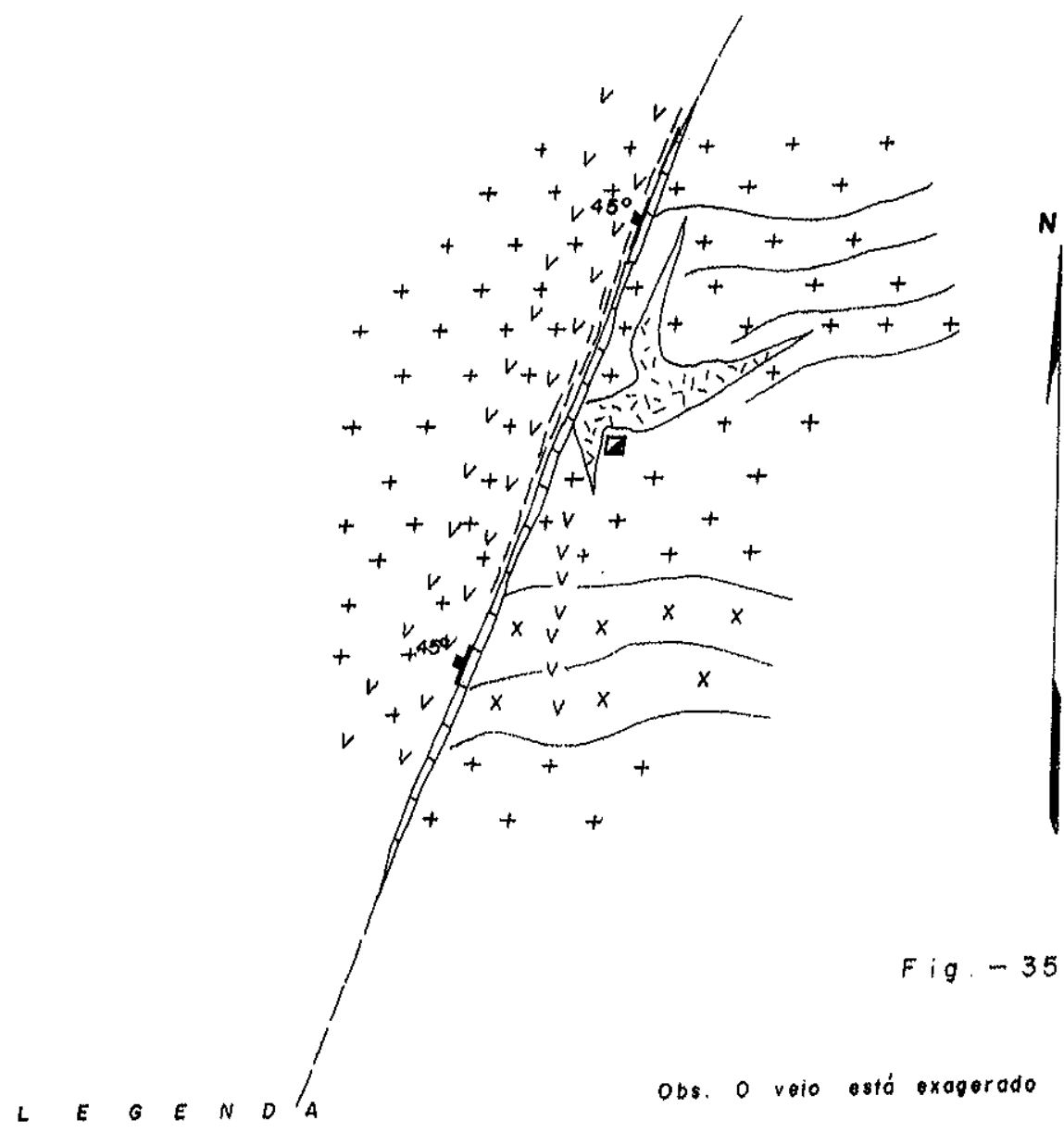

D POPO

Atitude do veio

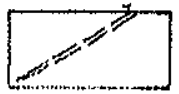

Holo propllltico

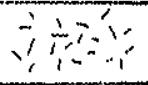

Gronito overmethodo, equigranulor, me'dio

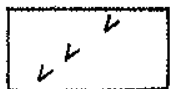

Diques de vulcônicos bósicos, multiplos, com espossuros de $20 \mathrm{~cm} 03 \mathrm{mis}$

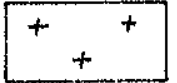

Monzo gronitos a granodioritos, oinzo a ro'soos, com quartzo, feldspoto potosslao, plapioclasio a biotita, oom enoloves ovalados de rochos basicas.

Rooho onolsolficado oom bandamento proselro, desoontinuo, alternanalo de leltos mesocratloos, com blotita, hornblenda. plaoloclasio do compesigáa diori-



Veio de quartzo loitoso oandodo, com pirtto, especularita o ouro. 
As rochas encaixantes são do tipo biotita monzogranitos a biotita granodioritos. Localmente, observa-se na capa do veio um espesso pacote de metabásicas sub-vulcânicas na forma de diques subparalelos ao filão. Estas rochas estão cloritizadas, cisalhadas, apresentando bolsões de material granítico, com desenvolvimento de expressivo halo propilítico e dobras de arrasto, evidenciando um movimento transcorrente sinistral (Figura 36).

O minério é do tipo veio de quartzo leitoso, de coloração ocre amarelada, friável, com disseminações de pirita, de granulometria fina, incorporando bandas de clorita xisto milonitizado.

O Filão do Cubu (GR-32), está alojado em uma possante fratura de cisalhamento mineralizada com extensão da ordem de 200 metros e espessura da zona mineralizada da ordem de 2 metros, (cf. Figura 37). O filão tem direção geral $\mathrm{N} 10 \mathrm{~W} / 70 \mathrm{SW}$, com desenvolvimento de expressivo horizonte de minério milonítico piritoso, apresentando sigmóides que evidenciam um movimento destral, provavelmente tratando-se de uma fratura de cisalhamento Tipo " $\mathrm{P}$ " ", vinculada à mega-estruturas de cisalhamento de direção, N70W (cf. mapa geológico, em anexo).

A nível microcópico, o minério é constituido essencialmente por pirita em grandes cristais de contorno angulosos, subidiomórficos, intensamente fraturados e localmente brechados, com resquícios de foliação cataclástica. As fraturas estão preenchidas pela ganga quartzosa. Observa-se ainda na pirita raras inclusões de calcopirita e ouro $(70-80 \mu)$, com formas sub-arredondadas.

O Filão do Erédio (PA-79), constitui um corpo mineralizado com extensão superior a 1000 metros, alojado em uma fratura de cisalhamento sinuosa de direção geral $\mathrm{N} 20.40 \mathrm{E}$, com mergulho de $80^{\circ}$ para $\mathrm{NW}$, evidenciando uma movimentação destral. O substrato geológico da região está representada por rochas granodioriticas e quartzo-dioritos da unidade Granitóides Arqueanos, afetadas por enxames de vulcânicas básicas e apófises de álcali-granitos, de granulometria fina e coloração rósea.

Durante o mapeamento da galeria de rumo $\mathrm{SE}$, aberta na profundidade de 29 metros da boca do poço (Figura 38), observou-se a existência de inúmeras bandas de cisalhamento na capa do veio de quartzo leitoso com pirita, calcopirita, bornita e óxidos secundários (Tabela 12).

O Filão do Zé Deco (PA-78) constitui um corpo mineralizado que se estende por cerca de 750 metros, segundo a direção geral N35E, com mergulhos da ordem de 70 a $85^{\circ}$ para NW (Figura 39). O substrato geológico está representado por biotita granitos equigranulares, bastante intemperizados, afetados por diques de micro-gabros. $\mathrm{Na}$ capa do veio de quartzo mineralizado observa-se o desenvolvimento de espesso halo sericítico milonitizado. 
PLANTA ESQUEMA'TICA

\section{$F I L A N O \quad D A \quad S E D E$ \\ ESCALA $1: 2000$}

$\begin{array}{llllll}0 & 20 \quad 40 \quad 60 \quad 100 \quad 120 & 60 & \mathrm{mt}\end{array}$

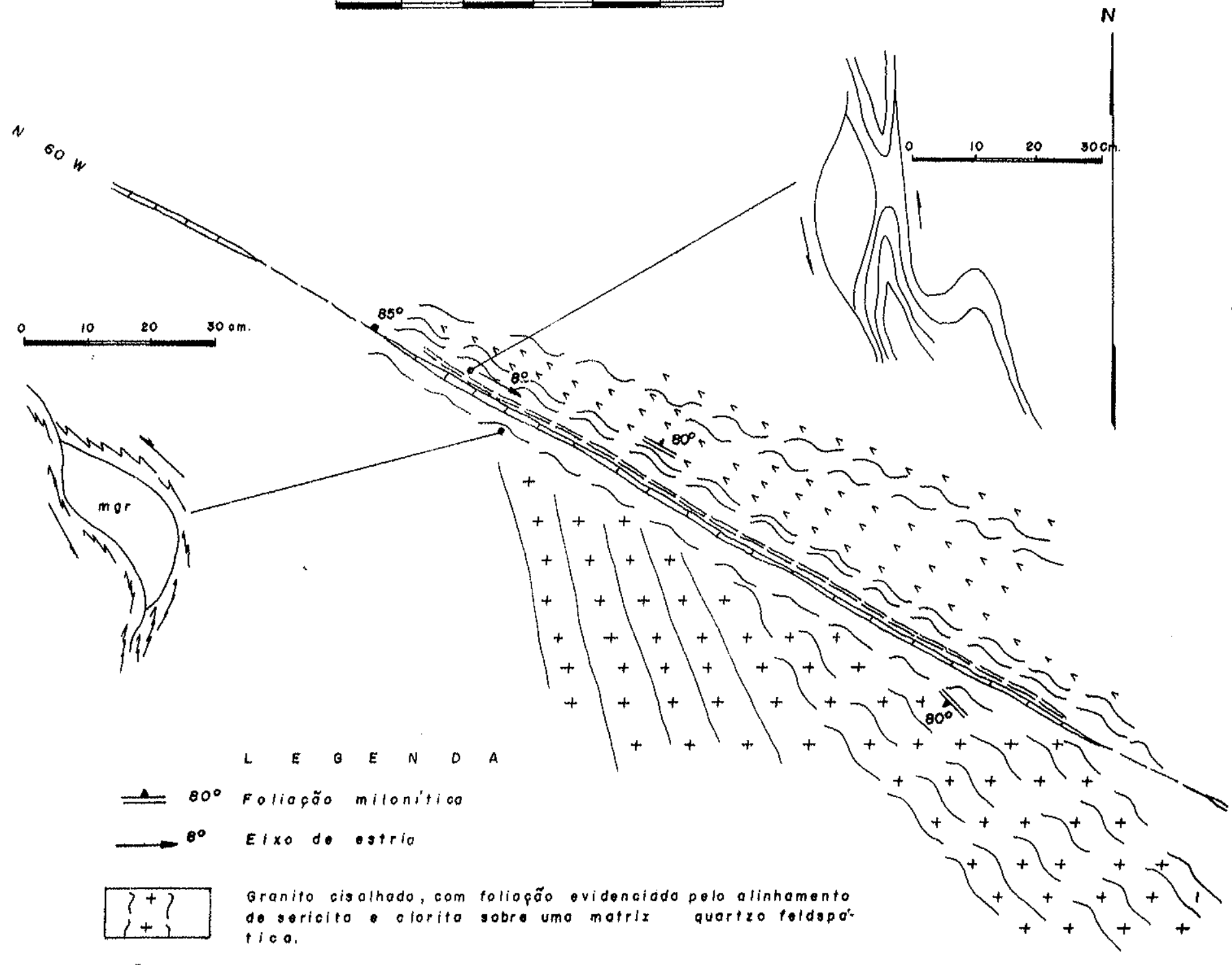

Mlorogranito de oranulometria fino o madio com bandamen

to flno, coolinizado do provarel composicão oranodlorio-

ica, potassifloodo com boloses de matorial poomátitioo.

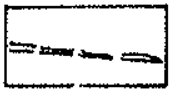

Halo de alterocbo propilitico com dobras de arasto com ixo ondulado, sub horizontalizado.

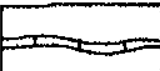

Volo de quartzo

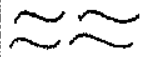

Zono de catociase

Motoba'sicas com enclovos de material aranitioo, tronsfor 
RE PRESENTACÃO ESQUEMA'TICA

\section{FILÃO DO CUBU (Gr3//32)}
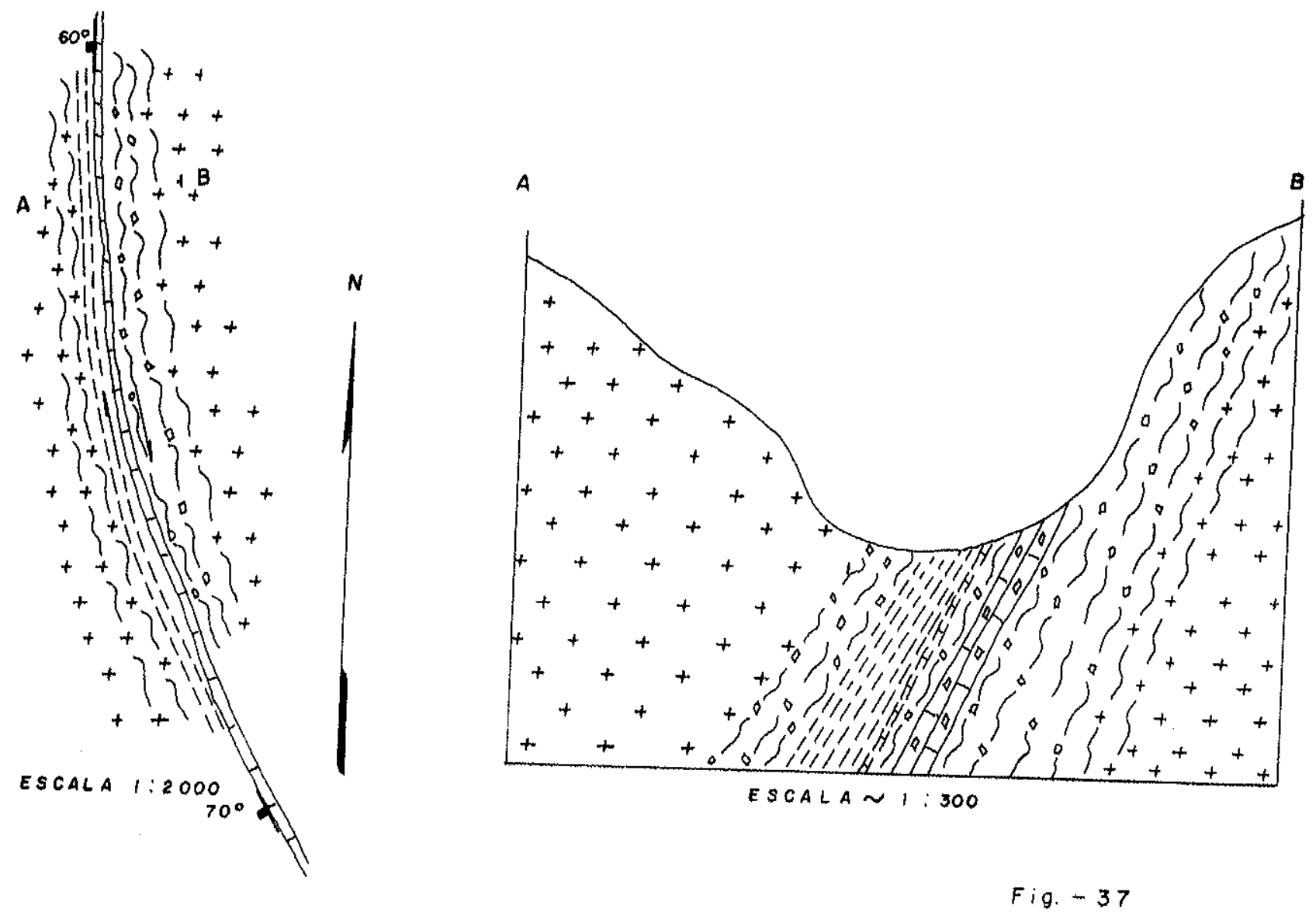

$L \quad E \quad G \quad E \quad N \quad D \quad A$

$20^{\circ}$

Atilude do velo

Volo do quertzo leltoso brechodo, oom pirltos subidiomotrfioas, centime'tricos cisithadoe

Volo de quortzo bandado, tipo minerilo milonitloo com mola do $15 \%$ de pirito

Miorobreaha gronftico com pseudomortos de pirito o venulaçóas quartzosos, percolo.

do oor oxido de ferro.

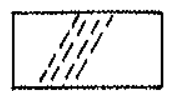

Holo sorigitico piritoso, com bondas milonitizodos.

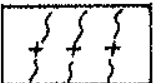

Grontio cisolhodo

Grontio cinzo a roseo, equigronulor, modolo, com plagioglosios coolinizados 
PLANTA ESQUEMA'TICA

$$
\begin{gathered}
\text { FILÃO DO HERE'DIO } \\
\text { ESCALA I: } 10000
\end{gathered}
$$

A

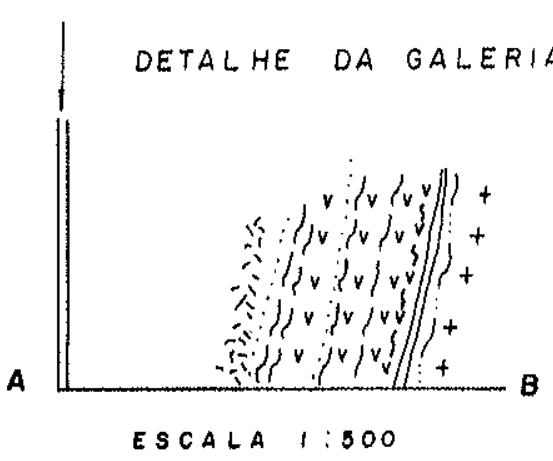

Obs. O vejo estó exagerodo

A (29mts.) 
PLANTA ESQUEMA'TICA

$$
\begin{gathered}
\text { FILÃO DO ZE' DECO } \\
\text { ESCALA I: } 5.000
\end{gathered}
$$

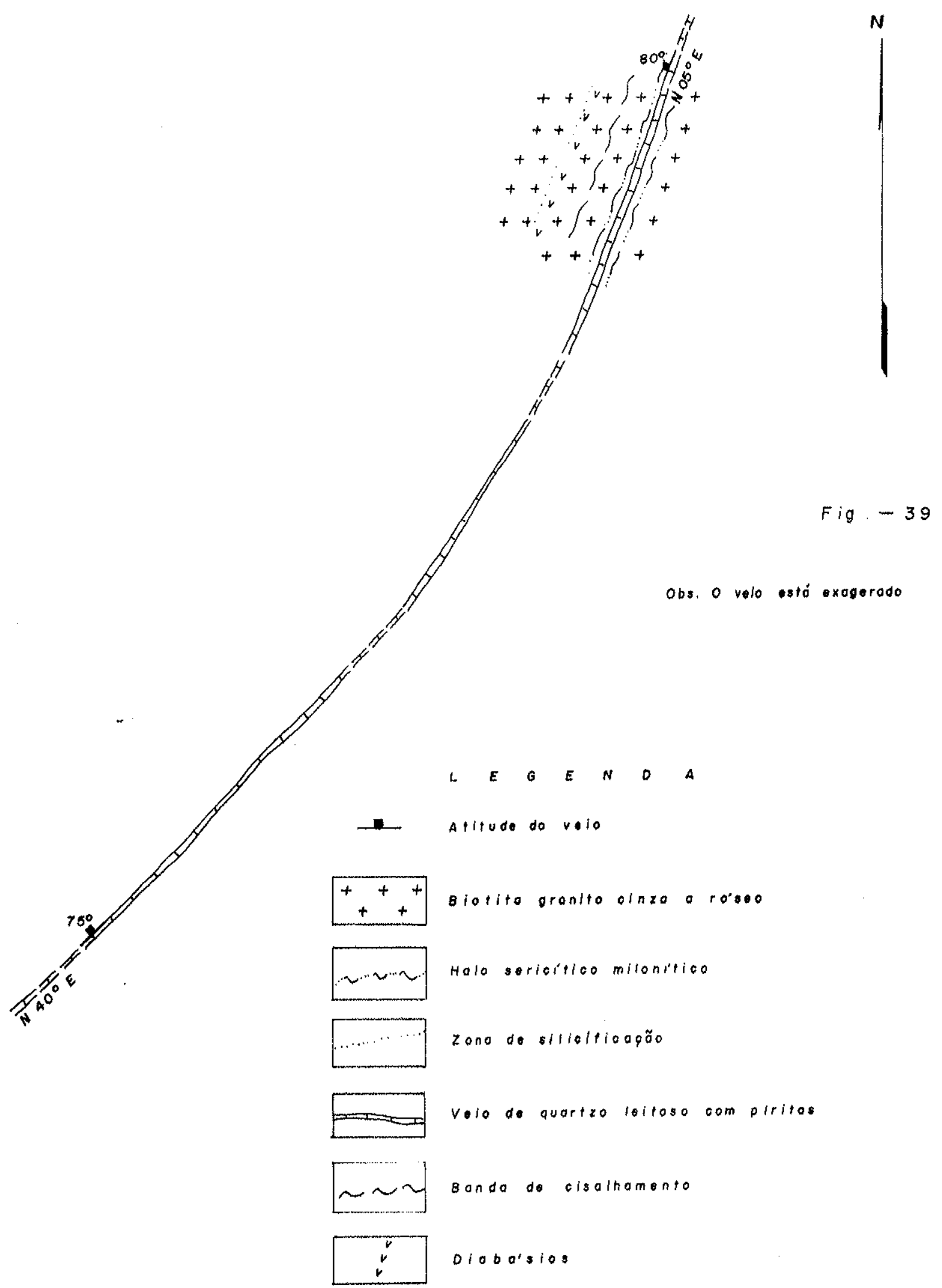




\section{2 - Depósitos Tipo II}

Constituem depósitos de pequeno porte, frequentemente com extensões menores que 150 metros, subverticais e descontinuos, por vezes em enxames sub-paralelos, condicionados a sistema de fraturas e falhas com direções preferenciais N55-75E e N25-40E, sem dúvidas, mais jovens que os veios mineralizados subordinados aos sistemas de cisalhamentos dúcteis de direção WNW.

Estes corpos estão posicionados preferencialmente no ambiente geológico dos Granitos Juruena. A área com maior concentração destes veios situase na faixa de contato entre os granitos Juruena e os granitóides Arqueanos, no interflúvio entre os corrégos Baixão do Paulista e Zé Deco, conforme mapa geológico em anexo.

Nestes corpos as feições típicas de regime dúctil são raras, predominando feições características de regime dúctil-rúptil, apresentando grande grande densidade de superficies estriadas, muitas vezes associadas a possantes veios de quartzo fracamente mineralizados (PA -53/65/73/156) e zonas de brechação (PA - 20/66/67).

Entre os corpos considerados como pertencentes a está tipologia, podemos relacionar os filões do Córrego do Paulista (PA - 18/74/75/76), da Grota do Simão (PA - 15/71/72), do Córrego do Zé Deco (PA - 80/100/113), filão do Aniceto (PA 148), filão do Viturino (PA-185), filão do Tarimba (PA - 189) e ainda os filões do Geraldo (MP - 21), Antena (MP - 31), Viúva (MP - 08), e outros nas imediações das cidades de Matupá e Peixoto de Azevedo.

Os veios são de quartzo leitoso, pouco sulfetados, com teor de pirita em torno de $1 \%$, estreitos $(10-15 \mathrm{~cm})$, encaixados em rochas monzograníticas caolinizadas, com halos siricíticos pouco desenvolvidos e baixos teores. (Tabela 12 e 13).

Os filões citados acima encontram-se, em sua maioria abandonados, e o teor do minério varia significativamente ao longo do corpo, com a garimpagem concentrando-se apenas nos pontos mais ricos com extensão média de 10 a 15 metros. Nestes locais, o teor médio recuperável pelos garimpeiros, obtido a partir do concentrado de bicas com rifles, após passar o minério em moinho hidrojet $\left(\mathrm{H}_{2}\right)$, situa-se em torno de $10 \mathrm{~g} /$ ton. Este teor inviabiliza completamente a exploração desses depósitos, uma vez que o custo agregado médio de produção, por tonelada de minério beneficiado via garimpagen, situa-se em torno de $15-20 \mathrm{~g} / \mathrm{ton}$.

\section{3 - Depósitos Tipo III}

Constituem mineralizações do tipo desseminado e/ou stockworks, alojadas em corpos graniticos intensamente transformados por fluidos hidrotermais, com modificações tanto da paragênese primária como da textura. A paragênese de alteração esta representada principalmente por sericita, feldspato potássico, epidoto 
e pirita (cf. Tabela 8). As texturas superimpostas resultantes são dos tipos granolepidoblástica, porfiroclástica, pegmatítica e protoclástica.

Os corpos de minério, em princípio, não possuem forma definida, mas estão notoriamente associados a sistemas de fraturas de cisalhamento discretas, e a falhas com grande densidade de superfícies estriadas.

$\mathrm{Na}$ região, a mineralização mais característica desse tipo de depósito, é o garimpo da Serrinha, em Matupá. Nesse local ocorrem várias pequenas serras destacadas no terreno (Foto 8 e Figura 21), e em pelo menos três serras, já foram exploradas mineralizações do tipo disseminado, associadas a níveis pegmatíticos e granitos hidrotermalizados.

O Granito Hidrotermalizado é uma rocha cinza esverdeada a rósea, maciça, inequigranular a porfirítica, com matriz de granulometria média a grossa. São marcantes as evidências de alteração hidrotermal de origem tardi-a pósmagmática (Fotos 8,9 e 20) já descritas no texto.

Nessas rochas a pirita na forma de cristais subidiomórficos, com dimensões da ordem de 0,1 a $2,0 \mathrm{~cm}$, encontra-se disseminada na rocha, perfazendo até $30 \%$ do volume da amostra (Foto 20).

$O$ ouro esta provavelmente associado a fase sulfetada. Em amostras do tipo composta de granito hidrotermalizado foram obtidos teores entre 0,4 a 9,5 ppm de ouro, com 2 a 43 ppm de cobre, e em média 1 ppm de prata. Em amostras pontuais com mais de $20 \%$ de pirita os teores variam entre 20,5 a $55,9 \mathrm{ppm}$. Amostras de granito Matupá sem pirita, apresentaram teor da ordem de $0,0 \mathrm{ppm}$ (Fyre assay).

Nas seções polidas estudadas (MP-10/10a/11/12/12a) verificou-se que o sufeto principal é pirita, com raras inclusões de calcopirita e bornita. Hematita, tabular com exsoluções lamelares de ilmenita ocorrem ao longo de micro fraturas na pirita. A pirita ocorre como cristais subidiomórficos, disseminado na ganga silicatada, com as bordas dos cristais fraturadas. $O$ ouro ocorre como microinclusões na pirita com dimenções de $(50-80 \mu)$, e localmente ao longo de trilhas de inclusões silicosas dentro da pirita.

Os Níveis Pegmatíticos apresentam coloração rósea avermelhada, com mega cristais centimétricos de microclínio pertítico, com intercrescimento de plagioclásio da ordem de milímetros. O quartzo ocorre preenchendo espaços intersticiais, com granulometria média a grosseira, leitoso e sem evidênciais de deformação. São frequentes bolsões de pirita maciça, com cristais subidiomórficos, de dimensões decimétricas, que constituem um tipo de minério rico (Fotos 20, 21 e 22).

$11,55 \mathrm{ppm}$.

Uma amostra desse tipo de material foi dosada por Fire assay com 


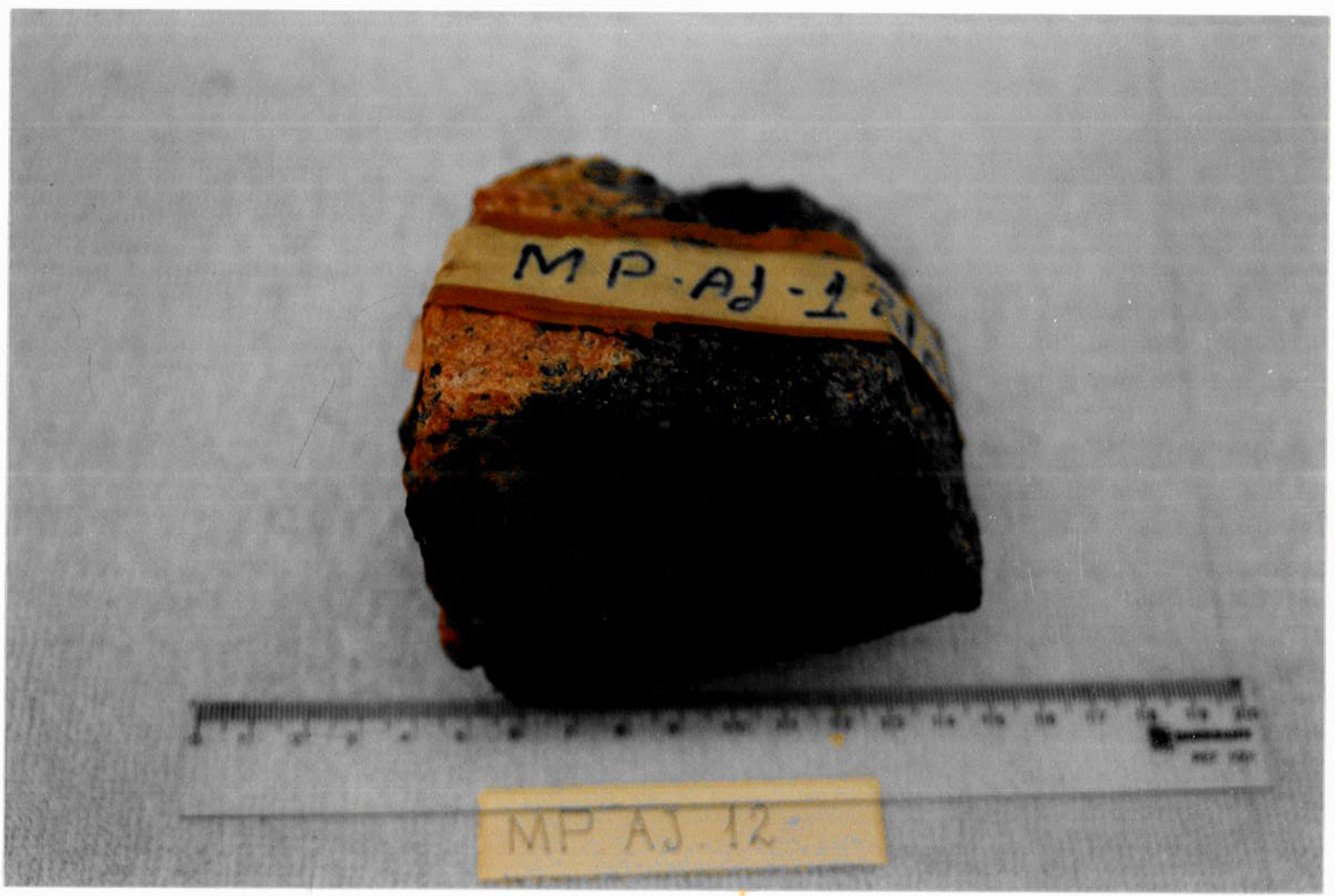

Foto 20: Detalhe do contato entre o granito hidrotermalizado piritoso e um nível pegmatítico (MP-11/12).

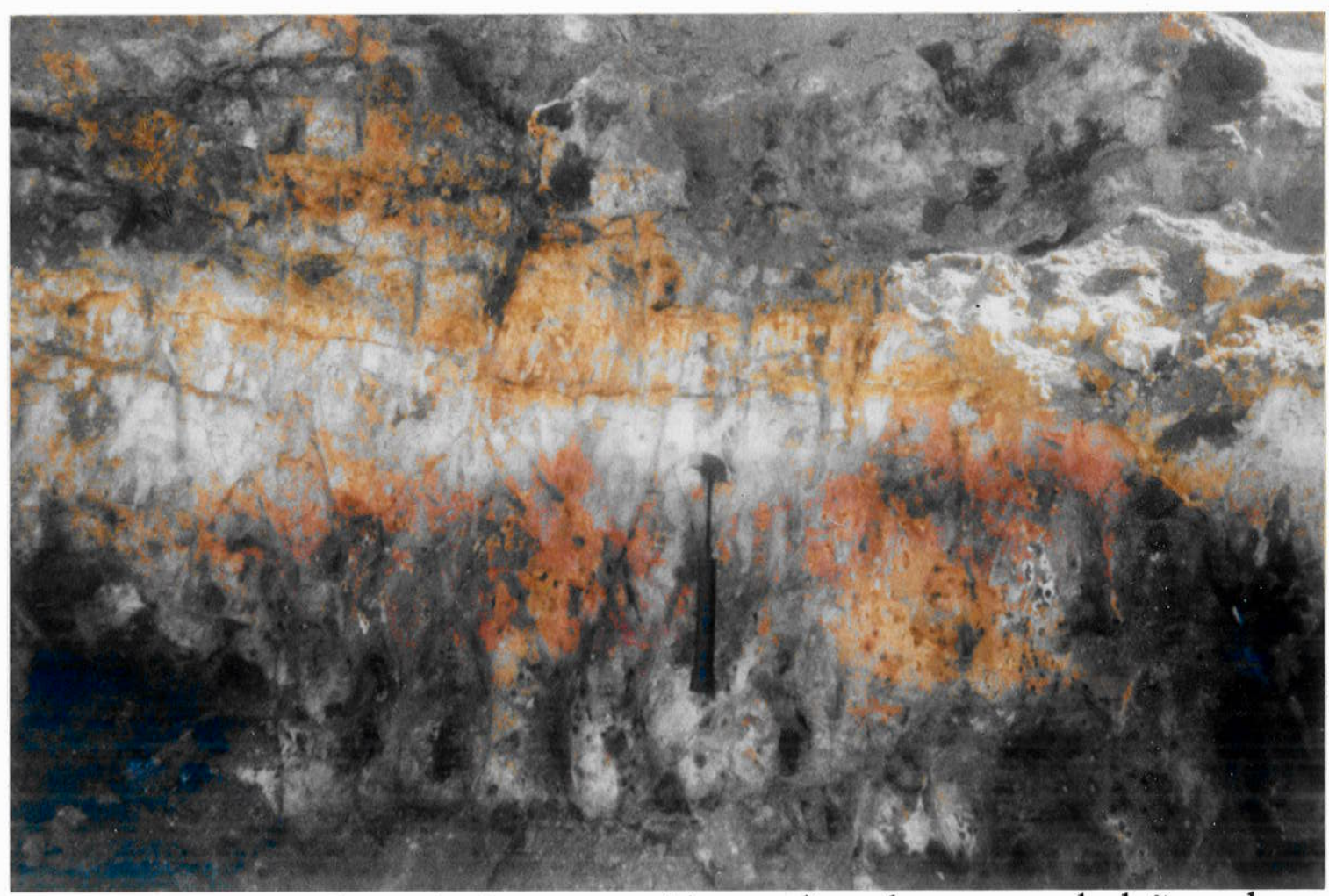

Foto 21: Aspecto dos níveis pegmatíticos alterados, com bolsões de piritas limonitizadas (MP-12). 


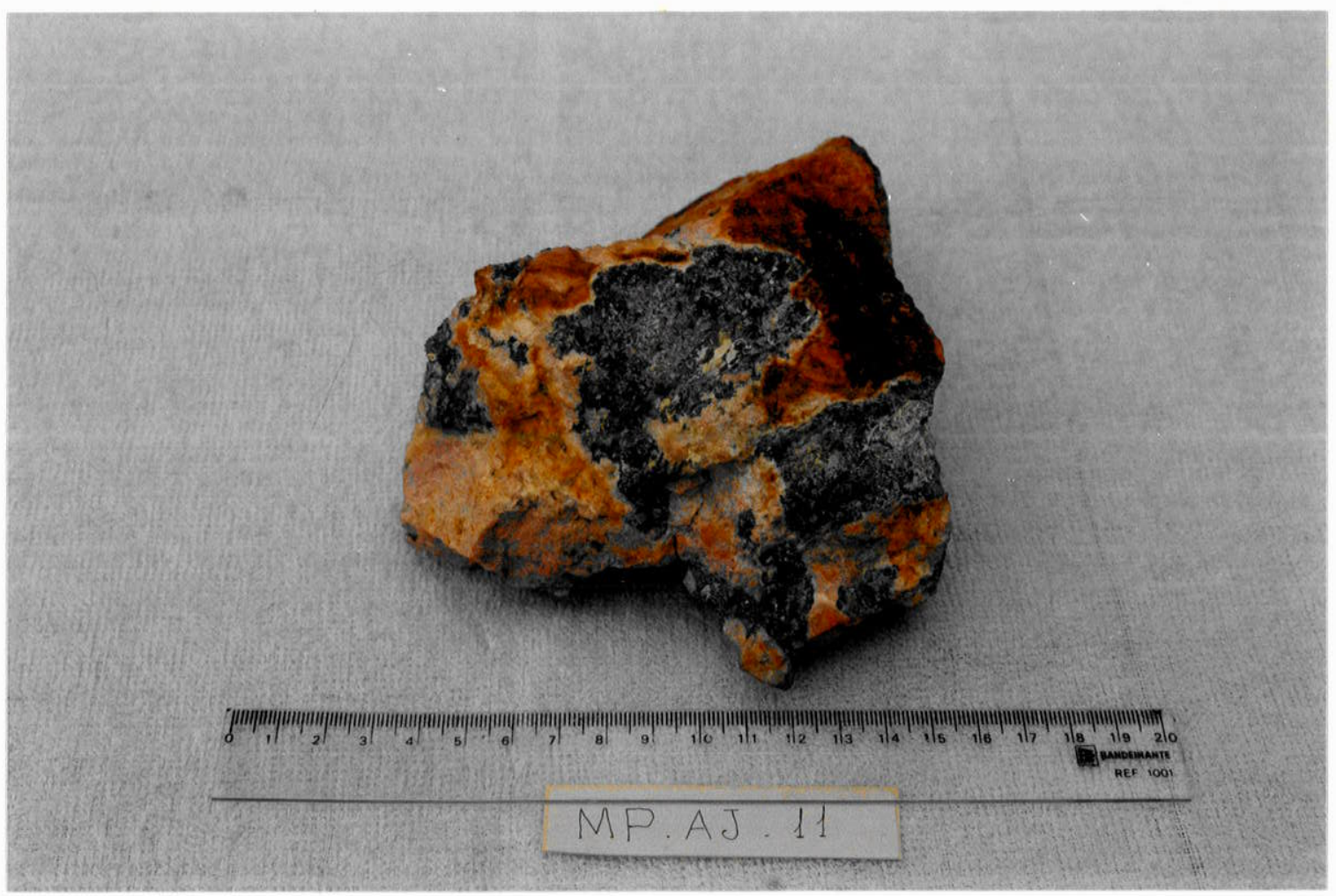

Foto 22: Detalhe dos bolsões de pirita nos níveis pegmatíticos (MP-12).

Esta tipologia, denominada "Tipo III", compreende mineralizações geradas em função dos sistemas hidrotermais e processos de alteração associados à genêse dos granitos transformados tipo Matupá. Neste tipo de depósito observa-se um importante controle estrutural, com a percolação das soluções ao longo de anisotropias pré existentes. Nestes termos, no garimpo da Serrinha, verifica-se a existência de sistemas de cisalhamento regionais de alto ângulo, de natureza dúctilrúptil, dispostos segundo as direções N70-80W/70-80SW e E-W/80S, predominantemente transcorentes, e localmente com movimentação inversa de sul para norte.

Associado ao sistema regional citado, verifica-se um persistente alinhamento de fraturas de cisalhamento, dispostas ao longo das direções N4050E/70-80SE, com estrias sub-horizontais, indicando movimentação predominantemente sinistral. No detalhe dos corpos de minério (Figura 21), observa-se que os mesmos estão condicionados, preferencialmente em fraturas subhorizontais, anastomosadas (Foto 9), provavelmente subordinadas a estruturação regional.

Os granitos Matupá possuem composição granodiorítica, monzogranítica e quartzo monzonítica, Figura 23, tendência calcio-alcalina e algumas feições petrográficas similares aos granitóides tipo I, Cordilheirano, de 
Pitcher $(1982,1987)$, com afinidade metalogenética para mineralizações tipo Au, $\mathrm{Cu}$ e Mo (pórfiros).

Os granitóides do Tipo I, juntamente com os Tipo S, foram caracterizados por Chappel e White 1974 (in: Pitcher, 1987), com base em estudos efetuados nos granitos Autralianos do Lachlanda Fold belt. Segundo estes autores, os granitos I seriam oriundos da fusão de rochas meta ígneas, constituindo as séries expandidas com gabros, tonalitos, granodioritos e granitos, tendo magnetita como óxido mais frequente.

Pitcher (1987) realça que, mesmo no caso dos depósitos tipo $\mathrm{Cu}-\mathrm{Au}$ pórfiros, notoriamente associados a arcos magmáticos, com granodioritos e tonalitos tipo I, existem restrições quanto a uma possivel parentagem direta entre os metais e os fundidos silicosos. O autor crê que essa associação seja indireta, com a fase metálica resultante de processos complexos de reciclagem, concentração e recristalização a partir das encaixantes.

Mesmo considerando, que os modelos petrogenéticos e metalogenéticos foram desenvolvidos principalmente através de estudos em maciços graníticos fanerozóicos, existem algumas feiçoes, que sugerem similaridade entre os depósitos Tipo III com os do tipo Cu-Au pórfiros, no caso:

- Encaixantes de composição cálcio-alcalinas;

- Associação dos corpos de minério com granitos pegmatíticos hidrotermalizados;

- Relação com rochas subvulcânicas, que afetam os granitos Matupá;

- Ocorrência em áreas restritas $\left(<1 \mathrm{Km}^{2}\right)$;

- Mineralizações preenchendo redes de fraturas;

- Associaçóes de minerais metálicos com pirita, e de forma subordinada calcopirita e bornita;

- Associações de minerais não metálicos, neo formados, incluindo microclínio, sericita, quartzo, carbonatos, epidoto e leucoxênio; e

- Alteração hidrotermal do tipo sericitização, cloritização e epidotização, em zonas de anisotropias. 


\section{CONCLUSÕES E RECOMENDAÇÕES}

- A expressiva concentração de depósitos auríferos na região de Peixoto de Azevedo está relacionada com a existência de terrenos granitognaíssicos arqueanos tipo TTG, com mega-enclaves de composição básica e prováveis restos de rochas supracrustais, afetados por mega-estruturas de cisalhamento transcorrentes, anastomosadas, orientadas na direção N-NW, provavelmente subordinadas à estruturas regionais alinhadas na direção $\mathrm{E}-\mathrm{W}$, que constituem zonas de descontinuidade crustal relevantes na evolução geodinâmica da região.

- As estruturas mesoscópicas observadas nas zonas de cisalhamento dúcteis não foram conclusivas para estabelecer o sentido preferencial de movimentação relativo das mesmas. Isto certamente se deve a longa história deformacional, com recorrência de eventos, e sobretudo, ao mascaramento das estruturas mais antigas, devido a impressão das últimas fases, sob condições dúctilrúpteis. Entretanto, a tipologia, padrão e disposição das fraturas de cisalhamento com relação às mega-estruturas, evidenciam tratar-se de zonas de transcorrência com movimentação sinistral, compátivel com a macro-estruturação proposta.

- Os Granitóides Arqueanos estão representados principalmente por tonalitos, dioritos e granodioritos, gnaissificados, metaluminosos e portadores de magnetita.

- As zonas de cisalhamento dúcteis constituem uma das raras expressões de relevo nos terrenos Arqueanos, sendo sustentadas principalmente por quartzo-sericita milonitos e micro-brechas.

- Os Granitos Juruena estão representados por biotita monzogranitos a granodioritos com hornblenda, calcio-alcalinos, metaluminosos a ligeiramente peraluminosos.

- Os enclaves dioríticos observados nos Granitos Juruena são petrograficamente e químicamente similares aos termos dioríticos da unidade Granitóides Arqueanos, com elevados teores de $\mathrm{FeO}$ e $\mathrm{MgO}$, representados na norma por altos percentuais de diopsídio, hiperstênio e magnetita.

- Os monzogranitos e granodioritos tipo Matupá têm afinidades calcio-alcalinas, e caracterizam-se pela intensidade dos processos hidrotermais superimpostos, com transformação da mineralogia primária, através de soluções tardi-a pós-magmáticas com notável afinidade aurifera. 
- A similaridade petrográfica e contemporaneidade dos Granitos Juruena com os termos menos transformados do Granito Matupá, evidenciam que o fator nível crustal pode ser um importante controle para a preservação das mineralizações disseminadas do Tipo III, uma vez que os Granitos Matupá, potencialmente portadores deste tipo de mineralização, ocorrem em regiões menos arrasadas topograficamente, onde ainda existem restos de coberturas pertencentes ao Grupo Uatumã.

- Neste trabalho foram caracterizados três tipos principais de mineralizações, ou seja:

- Mineralizações do tipo I, do tipo preenchimento de fraturas condicionadas às estruturas de cisalhamento dúcteis préUatumã e muito provavelmente formadas no mesmo contexto de evolução dos terrenos arqueanos propostos para a região.

- Mineralizações do tipo II, estão associadas ao emplacement dos granitos tipo Juruena, segundo estruturas dúcteis-rúpteis de direção N40-70E

- Mineralizações do tipo III, intimamente associadas aos processos hidrotermais associados à geração dos granitos transformados Matupá, condicionando sistemas similares aos do tipo pórfiros, com alteração pervasiva do tipo sericitização, cloritização carbonatação e epidotização. As mineralizações estão preferencialmente alojadas em zonas de descontinuidade estrutural, ou mesmo no cruzamento de estruturas geradas em regime preferencialmente rúptil.

- Os veios associados às estruturas cisalhantes (Depósitos tipo I) não apresentam evidências de significativas rotações dos eixos deformacionais, que viessem a gerar eventuais veios dobrados, sendo raros os filões alojados nas fraturas com formas sigmoidais, caso dos filões do Mineiro, Melado e Domingos. Tal fato sugere que a geração dos veios está relacionada a fases tardias na evolução das zonas de cisalhamento dúcteis, certamente em condições dúcteis-rúpteis.

- Em termos gerais os filões de quartzo auríferos da região de Peixoto de Azevedo têm, em média, extensão inferior a $100 \mathrm{~m}$, os teores variam significativamente ao longo dos corpos, tendendo a se tornarem mais elevados nos espaços gerados pelas irregularidades e sinuosidades existentes ao longo do plano de fraturamento, que constituem zonas distensionais, ou mesmo formarem ore shoots, quando a fratura intercepta rochas encaixantes mais reativas (sub-vulcânicas básicas), que favorecem a deposição de sulfetos e ouro. 
- É frequente o posicionamento de corpos de minério ao longo de fraturas de cisalhamento, geradas no contato entre litologias de diferentes competências. Notadamente no contato granitos e sub-vulcânicas básicas, as últimas intensamente fraturadas, cisalhadas e hidrotermalizadas, na forma de corpos tabulares dispostos sub-paralelamente ao alinhamento do filão.

- Nos corpos mais enriquecidos observou-se a existência de apófises de granitos pórfiros e álcali-granitos, notoriamente tardios, e que em vários corpos de minério certamente contribuiram para remobilizar o ouro e provocar o enriquecimento das mineralizações, caso verificado na filão do Naiuram.

- Na maioria dos filões verificou-se a existência de espessas zonas de alteração com enriquecimento supérgeno, atingindo por vezes profundidades superiores a 40 metros. Nesta interfacie o minério quartzoso, com ouro liberado e por vezes visível, apresenta-se frequentemente associado com óxidos amorfos de ferro, com texturas reliquiares, tipo boxworks, casas de abelha e coloformes, ao longo de fraturas.

- Nos filóes situados em locais de relevo plano, ocorre frequentemente dos veios estarem mais enriquecidos em uma determinada profundidade, que a princípio deve corresponder ao nível de oscilação do lençol freático.

- $\mathrm{Na}$ área, não foram verificadas mineralizações auríferas indubitavelmente associadas às litologias pertencentes ao Grupo Uatumã, inclusive não sendo mapeado nenhum garimpo na principal área de ocorrência desta unidade.

- Os dados geoquímicos obtidos nos halos primários, permitem verificar um relativo enriquecimento em potássio e bário nos halos sericíticos e concentrações anômalas de $\mathrm{Cu}, \mathrm{Ni}$ e $\mathrm{Bi}$ nos halos propilíticos, desenvolvidos nas proximidades de encaixantes básicas.

- Os trabalhos de pesquisa a serem efetuados nos eventualmente diferentes ambientes granitogênicos abordados no texto, devem priorizar os seguintes pontos:

- Caracterização petrográfica das assembléias graníticas, com identificação daquelas que são encaixantes preferenciais dos depósitos conhecidos, e dos tipos petrográficos com reconhecida atuação na geração de depósitos auríferos.

- Definição das estruturas mineralizadas e seu relacionamento com os binários de cisalhamentos, estabelecendo ordens de grandeza com relação à intensidade de circulação de fluídos. 
- Verificar a existência de sub-ambientes distensionais, anisotropias pré-existentes, unidades litológicas mais reativas, halos de alteração, contatos litológicos e nível crustal de posicionamento dos corpos.

- A presença de solos transportados nas regióes de Alto Alegre, com perfis da ordem de $10 \mathrm{~m}$, recobrindo sedimentos aluvionares, constitui um fator a ser considerado em trabalhos de prospecção geoquímica.

- A deficiência de mapas geológicos de detalhe, o espesso manto de intemperismo e a existência de halos hidrotermais tornam a utilização das técnicas de tratamento multi-espectral de imagens de satélite e levantamentos geofísicos, fundamentais para os trabalhos de campo. Cabe realçar que perfis magnetométricos efetuados nos filões do Paraíba, Mineiro e Aniceto destacaram perfeitamente o corpo filoneano como uma anomalia negativa pronunciada, provavelmente em função do posicionamento dos corpos tabulares de sub-vulcânicas básicas e pela presença de magnetita em alguns veios. 


\section{REFERÊNCIAS BIBLIOGRÁFICAS}

ALMEIDA, F.F.M. de; HASUI, Y; NEVES, B.B. de e FUCK, R.A. 1977 Províncias Estruturais Brasileiras. Atas do Simp. Geol. Nordeste, p. 363 391, Campina Grande, PB.

ALMEIDA, F.F.M de 1978 - A evolução dos Crátons Amazônico e do São Francisco Comparada com a de seus homólogos do Hemisfério Norte. In. CONGRESSO BRASILEIRO DE GEOLOGIA, 30 Recife. Anais do Recife. SBG. 1978 , v.6, p. 2393 - 407.

AMARAL, G. 1984 - Província Tapajós e Província Rio Branco. In : ALMEIDA, F.F.M. \& HASUI, Y. eds. O Pré - Cambriano do Brasil. S. Paulo, Blucher, p. $6-35$.

ANDRADE, A.F. de et al. 1978 - Projeto Tapajós - Sucunduri, relatório de integração geológica. Manaus. DNPM / CPRM, 3v.

ANHAEUSSER, C.R. et al. 1969 - A reappraisal of some aspects of precambrian shield geology. Bulletion of the Geological Society of America, Boulder, 80 (11) ; $2175-2200$.

ARAÚJO, V.A. de et alii. 1975 - Projeto Manissuá Missu : reconhecimento geológico; relatório fínal. Goiânia, DNPM / CPRM, 4v.

BARBOSA, P.E. ; LORENZI, V.E. e ULBRICH, H.G. 1985 - Granitóides da região de São Pedro do Iriri : Considerações preliminares In : Simpósio de Geologia da Amazônia, Il Belém, SBG, v 1, p. 22 - 43.

BATEMAN, A.M. 1965 - Economic. Mineral Deposits. Second Edition. Jonh Willey e Sons. New York. London. 916 p.

BAXTER, J.L.; YATES, M.G. and ROWLANDS, A.T. 1991 - Estimationa of reserves and resources. In: Shear Zone hósped deposits. Proceedings Australasian Institute of mining and metallurgy, Melbourne, v 2, p. 17 - 23.

BERBERT, C.O. 1990 - Geologia do ouro DNPM - CVRD. Principais Depósitos Minerais do Brasil, v.3, p.289-300. 
BERGER, B. R. 1988 - Lithologic and Tectonic Setting of Epithermal Gold - Siver Deposits in Western North America. In: Goode, A. D. T. et al., eds. Gold 88, melbourne, 22; $154-159$.

BETTENCOURT, J.S.; DAMASCENO, E.C.; FONTANELLI, W.S.; FRANCO, J.R.M.; PEREIRA, N.M. 1981 - Brazilian Tin Deposits and Potencial Paper 3 (ii), Fipth World Conf. Tin, Kuala Lumpun, 69 p.

BIZINELLA, G.A et ali 1980 - Projeto Tapajós - Sucurundi, Relatório Final, Manaus, DNPM / CPRM, 8v.

BOWDEN, P. ; BATCHELOR, R.A.; CHAPPEL, B.W.; DIDIER, J. ; LAMEYRE, J. 1984 - Petrological, Geochemical and Source Criteria for the Classification of Granitic Rocks : a Discussion. Phys. Earth and Planet. inter., $35: 1-11$.

BOYLE, R.W. 1979 - The geochemistry of gold and its deposits. Geol. Survery of Canadá. Bull 280. Energy, Mines and Resources Canadá. 576 p.

BOYLE, W.R. 1987 - Gold - History and Genesis of Deposits. Van Nostrand Reinhold Company in. 1 ed, New York. 671 p.

BOULTER, C.A.; Fotios, M.G. and Phillips, G.N. 1987 - The Golden Mile Kalgoorlie : A giant gold deposit localized in ductile shear zones by structurally induced infiltration of an auriferous metamorphic fluid. Econ. Geol. , v.82, p. 1661 - 1678 .

BURG, J.P. ; LAURENT, P. 1978 - Strain analysis of a shear zone in a granodiorite. Tectonophisics, 47, p. $15-42$.

CARVALHO, M.S. \& FIGUEIREDO, A.J.A. 1982 - Caracterização Litoestratigráfica da Bacia de Sedimentação do Grupo Beneficente no Alto Rio Sucunduri, AM. An. 1 Simp. Geol. Amaz. 1:26-44. Belém.

CLARKE, D. 1990, 1992 - Newpet - Basic Professional Development System. Version 7.0 - Copyright Microsoft Corp.

CORDANI, U.G.; TASSINARI, C.G.; TEIXEIRA, W.; BASEI, M.A.S. and KAWASHITA, K. 1979 - Evolução Tectônica da Amazônia com base nos dados geocronológicos. In. CONGR. GEOL. CHIL., Aricá, 1979. Actas Aricá, 4: 137 - 148. 
CORDANI, U.G. \& BRITO NEVES, B.B. 1982 - The Geologic Evolution of South America During the Archean and Early Proterozóic, Rev. Bras. Geoc., 12: $78-88$.

CORREA FILHO, F das L. 1985 - Projeto Ouro e Gemas de Mato Grosso. Convênio DNPM?CPRM. Relatório Anual, 46p.

COLVINE, A.C. 1988 - Gold mineralization in the Province Superior, Canadá: a product of terminal archean cratonization. In Goode, A.D. T. et al., eds. Gold 88, Geol. Soc. of Australia, 22; 36 - 44.

CUNHA, B.C.C.; POTIGUAR, L.A.T.; IANHEZ, A.C.; BEZERRA, P.E.L.; PITHAN, J.H.L.; SOUZA JÚNIOR, J.J.; MONTALVÃO, R.N.G.; SOUZA, A.M.S.; HILDRED, P.R.; TASSINARI, C.C.G. 1981 - Geologia In: MME, PROJETO RADAM - BRASIL. ed. Folha SC.22 - Tocantins Levantamento de Recursos Naturais. Rio de Janeiro. p. 21 - 196.

DALL'AGNOL, R. 1982 - Estudo comparativo de alguns maciços graníticos pós Transamazônicos da Amazônia Oriental : In: CONGR. BRAS. GEOL., 32, Salvador, 1982. Anais Salvador, SBG, v.2, p. 500-513.

DALL'AGNOL, R.; SCHUCKMANN, W.K.; BASEI, M.A.S.; SCHELLER, T. 1984 - Novos dados geocronológicos e estudos de elementos - traços de maciços graníticos anorogênicos da Amazônia Oriental, Estado do Pará ( Brasil ). In. SIMP. AMAZ., 2, MANAUS, 1984. Anais Manaus, MME DNPM.

DÄLL'AGNOL, R.; VIEIRA, E.A.P;; SÁ, C.A.S.; MEDEIROS, H.; GASTAL, M.C.P.; TEIXEIRA, N.P. 1986 - Estado atual do conhecimento sobre as rochas granitóides da Porção Sul da Amazônia Oriental. Rev. Bras. Geoc. , $16(1): 11-23$.

DALL'AGNOL, R.; BETTENCOURT, J.S.; JORGE JOÃO, X.S.; MEDEIROS, H.; COSTI, H.T.; MACAMBIRA, M.J.B. 1987 - Granitogenesis in the Northern Brasilian Region : a review, Rev, Bras. Geoc., 17 (4): 382 - 403.

DALY, M:C. 1988 - Crustal shear zones in Central Africa : a kinematic approach to proterozoic tectonic. Episodes, 11 (1): $5-11$.

DEER, W.A.; HOWIE, R.A. \& ZUSSMAN, J. 1981 - Minerais Constituintes das Rochas - uma Introdução. In: Fundação Calouste Gulbenkian, Editora, Lisboa. Portugal. 558p. 
FERRAN, A. 1988 - Depósito de ouro de Salamangone e Mutum, Calcoene, Amapá. DNPM - CVRD. Principais depósitos minerais do Brasil, v.3, p. 581 -588 .

FOSTER, R.P. \& WILSON, J.F. 1984 - In FOSTER, R.P., ed. Gold' 82: The Geology, Geochemistry and Genesis of Gold Deposits. A.A. BALKEMA, ROTTERDAM. $735 \mathrm{pp}$.

FOSTER, R.P. 1985 - Trans. Geol. Soc. S. Afr., v.88: $109-133$.

FOSTER, R.P. 1988 - Archaen gold mineralization in Zimbabwue: implications for metallogenesis and exploration. In: Goode, A.D.T. et al., eds. Gold 88, 22; 62 -72 .

FRIPP, R.E.P. 1976 - Stratabound Gold Deposits in archean banded iron formation, Rodesia. Econ. Geology, v. 71, p. 58 -75.

FYFE, W.S. \& HENLEY, R.W. 1973 - Some thoughts on chemical transport processes with particular reference to gold. Minerals Sci. Engng. v.5, p. 295 303.

FYFE, W. \& KERRICH, R. 1984 - Gold: natural concentration processes. In : FOSTER, R.P. ed., GOLD 82, Geology, geochemistry and genesis of gold deposits. Balkema, Rotterdam: $99-127$.

GASTAL, M.C.P. 1988 - Magmatismo ácido - intermediário do Proterozóico Médio na Região de Rio Maria, SE do Pará: Discussão quanto a tipologia. In: CONGR. BRAS. GEOL., 35, Belém. Anais... Belém, SBG, v.3, p. 1147 1163.

GONÇALVEZ, M.G.B.; DALL'AGNOL, R.; VIEIRA, E.A.P.; MACAMBIRA, M.J.B., E SENTA, N.D. 1988 - Geologia do Maciço Anorogênico Cigano. Vale do Rio Parauapebas - PA. In: Congr. Bras. de Geol, 35, Belém, SBG, v 3, p. $1132-1146$.

GROVES, D.I., PHILLIPS, G.N., HO, E.E., HENDERSON, C.A., CLARK, M.E. and Wood, G.M. 1984 - In: FOSTER, R.P., eds. Gold 82. Rotterdam., 753pp.

GROVES, D.I., PHILlIPS, N., HO, S.E., HOUSTOUN, S.M. and STANDING, C.A. 1987 - Econ . Geol. , 82; 2045 - 2058, 
HARRIS, L.B. 1987 - A tectonic framework for the western australian shield and its significance to gold mineralization: a personal vien. Geology Departament \& University Extension, University of Western. Australia, 11, p. 1 - 27.

HODGSON, C.J. 1989 - The structure of shear - related, veim type gold deposits: A review. Ore Geol. Rev. 4: $231-273$.

HUNH, S.R.B., SANTOS, A.B.S., AMARAL, A.F., LEDSHAN, E.J., GOUVEIA, J.L.; MARTINS, L.P.B., MONTALVÃO, R.M.G., e COSTA, V.G. 1988 Terreno granito - greenstone da região de Rio Maria, Sul o Pará. In: Cong. Bras. Geol., 35, Belém, 1988. Anais Belém, SBG. v.3, p.1438- 1472.

IRVINE, T.N. and BARAGAR, W.R.A. 1971 - A guide to the chemical classification of the common vulcanic rocks, vol. 8, p. $523-548$.

JARDIM DE SÁ, E.F. 1984 - Aspectos estruturais e tectônicos de granitóides. In: XXXIII Congresso Brasileiro de Geologia, Rio de Janeiro, VI : 2787 - 2814.

KERRICH, R, 1986 - Fluid Transport in Lineaments : Royal Soc. Philos. Trans., v. 317 A, p. $219-251$.

LACERDA, H. 1990 - Contribuição à tipologia dos depósitos auríferos da região Brasil Central. Revista Brasileira de Geociências, $20(1-4)$ : p. 32 - 45.

LAMEYRE. J. and BOWDEN, P, 1982 - Plutonic Rock Types Series: Descrimination of various Granitoid series and Related Rocks. Volc. Geother. - Res., 14: 169 - 186.

LEAL, J.W.L., et alii 1978 - Geologia In: BRASIL. Departamento Nacional da Produção Mineral. Projeto RADAMBRASIL. Folha SC. 20. Porto Velho. Rio de Janeiro. 668p. (levantamento dos recursos naturais, 16). p. 17 -184.

LE MAITRE, R.W., (ed), 1989 - A Classification of Igneas Rocks and Glossary of Terms, Blackwell, oxford, 193 p.

LEONARDOS, O.H, 1991 - The Cumaru meso thermal granodiorite - Hosted gold mineralization, Amazon Craton, Brasil. In Ladeira, E.A. ed, Gold, 91 : Brasil, p. $557-562$.

MACAMBIRA, M.J.B. et alii 1990 - Geocronologia da Granitogênese da Província Amazônica Central Brasileira: Uma revisão. Rev. Bras. Geoc. 20 (1-4) : 258 -266 . 
MANIAR, P.D. and PICCOLI, P.M., 1989 - Tectonic discrimination of granitoids, Geological Society of America Bulletin, vol. 101, p. 635 - 643.

MARAUÍ, C.A. \& VEIGA, A.T.C. 1985 - Síntese Geológica da Região de Novo Planeta - Alta Floresta (MT), Anais do II Simpósio de Geologia da Amazônia, Belém.

MEDEIROS, H. \& DALL'AGNOL, R. 1988 - Petrologia da porção leste do batólito granodiorítico Rio Maria, sudeste do Pará. In: CONGR. BRAS. GEOC., 35, Belém, 1988. Anais SBG, V.3 p. 1488 - 1496.

MELO, D. P. \& FRANCO, M. do S. M. 1980 - Geomorfologia. In: Brasil. DNPM. Projeto RADAMBRASIL. Folha SC. 21 Juruena. Rio de Janeiro, 1980. (Levantamento de Recursos Naturais, 20).

MONTALVÃO, R.M.G., TASSINARI, C.C.G.; TEIXEIA, W.; e VASCONI, A.V. 1988 - Caracterização geocronológica $\mathrm{Rb}-\mathrm{Sr}$ dos terrenos granodioriticos e trondjemíticos da região de Rio Maria - Sul da Serra dos Carajás, In: Congr. Bras. Geol., 35, Belém. Anais SBG. v.3, p. $1478-1487$.

NIMER, E. e BRANDÃO, A.M.P.M. 1989 - Balanço hídrico e clima da região dos cerrados, Rio de Janeiro. - IBGE, 116p.

NISBET, E.C. 1984 - In: FOSTER, R.P., ed., Gold' 82: The Geology, Geochemisty and Genesis of Gold Depósits Rotterdam, 753p.

PHILLIPS, G.N. 1986 - Geology and alteration in the Golden Mile, kalgoorlie. Econ. Geol. Geol. v, 81, p. 779 - 808 .

PITCHER, W.S. 1982 - Granite type and tectonic environment. In Mountain Building Processes. K. Hso, editor. Academic. Press, 19-40.

PITCHER, W.S. 1987 - Granites and yet more granites forty years on Geologische Rundschaw 76/1, p. 51-79.

RAMSAY, J.G. ; Grahan, R.H. 1970 - Strain variation in shear belts. Canadian J. of Earth Sc. 7, p. $786-813$.

RAMSAY, J.G. 1980 - The crack - seal mechanism of rock deformation. Nature, v. 284, p. $135-139$. 
RAMSAY, J.G, and Huber, M.I. 1983 - The techniques of modern structural geology. V. 1. Strain analysis. Academic Press.

RAMSAY, J.G. and Huber, M.I. 1987 - The techniques of modern structural geology. v. 2. Academic Press.

ROBERT, F. and Brown, A. 1986 - Archean gold-bearing quartz veins at the sigma Mine, Abitibi Greenstone Belt, Quebec. Econ. Geol. v. 81, p. 578 - 615.

ROBERTS, R.G. 1987 - Archean lode gold deposits. Geoscience Canadá. v.14, n 1, p. $1-19$.

RICHARD. M. et al. 1991 - Archean granitoid - Hoster gold deposits of the Abitibi greenstone belt, Quebec: An example from the Pierre Beauchemin mine. In Ladeira, E.A., ed. Gold 91: Brasil, p. 551 - 556

SANTIAGO. A.F, et al. 1980 - Estratigrafia preliminar da bacia sedimentar do Alto Tapajós. In : CONGRESSO BRASILEIRO DE GEOLOGIA, 31. Camboriú. Anais Florianópolis. SBG. v. 2, p.786-97.

SANTOS, D.B. dos. et ali 1982 - Coberturas vulcano - sedimentares e sedimentare pré-cambrianas da Plataforma Amazônica In: Simpósio de Geologia I, Belém, SBG, p. $113-177$.

SANTOS, J.O.S. 1984 - Classificação das Rochas vulcânicas Uatumã. In: Congresso Brasileiro de Geologia, 33, Rio de Janeiro. Anais Rio de Janeiro, - SBG. v. 9, p. $4526-4538$.

SANTOS, J.Q.S. \& LOGUERCIO, S.O.C. 1984 - A parte meridional do Cráton amazônico (Escudo Brasil Central ) e as bacias do Alto Tapajós e Parecis Alto Xingu. In : Scobbenhaus, C,; Campos, D.A.; Derze, F.R. \& Asmus H.E. (coordes). Geologia do Brasil, p. $93-127$.

SIBSON, R.H. 1977 - Fault rocks and fault mechanisms. Bull. Geol. Soc. London, 133: $191-213$.

SEWARD, T.M. 1973 - Thio-complexes of gold and the transport of gold in hydrothermal ore solutions: Geochimica et cosmochimica Acta, v. 37, p. 379 399.

SEWARD, T.M. 1984 - The transport and deposition of gold in hydrothermal sistems, in: Foster, R.P., ed., Gold' 82: Rotterdam, p. $165-181$. 
SILLITOE, R.H. 1988 - In: Goode, A.D.T. et al., Gold 88; Geological Soc. of Australia, 22: $127-138$.

SILVA, G.H. et alii. 1974 - Esboço geológico de parte da Folha Sc. 21. Juruena. In: Congresso Brasileiro de Geologia, 28. Porto Alegre. Anais do Porto Alegre, SBG, 1974 v. . p. $309-20$.

SILVA, G.H, et alii. 1980 - Geologia In: DNPM - Projeto RADAMBRASIL. Folha Sc.21 - Juruena - RJ. v. 20: 21 - 116.

SIQUEIRA, L.P. de. 1988 - Bacia do Parecis. Relatório Petrobrás DEPEX SEBINT.

SOUZA, A.M.M. de et alii. 1979 - Reconhecimento geológico do limite Pará Mato Grosso. Projeto São Samuel. Brasília, DNPM - CPRM, 1979, 27p.

STRECKEISEN, A.L. 1976 - To each plutonic rock its proper name - Earth Sci. Rev. 12, 1- 33 .

TASSINARI, C.C.G. \& TEIXEIRA, W. 1978 - Estudo geocronológico e estratigráfico das rochas pré-cambrianas da Folha Sc. 21 - Juruena. Salvador. Projeto RADAMBRASIL, 1978 n.p. (relatório interno, 168 - G.).

TASSINARI, C.C.G,; TEIXEIRA, W; SIGA Jr., O. 1978 - Considerações cronoestratigráficas da região das Chapadas do Cachimbo e Dardanelos. In: CONGR. BRAS. GEOL., 30, Recife, 1978. Anais Recife, SBG. v.1, p. 477 490.

TASSINARI, C.C.G. 1981 - Evolução geotectônica da Província Rio Negro Juruena na região Amazônica. Dissertação de Mestrado. Inst. de Geociências. USP, São Paulo.

TEIXEIRA, W; TASSINARI, C.C.G.; CORDANI, U.G. KAWASSHITA, K. 1989 - A review of the geocronology of the Amazônian Craton: Tectonic implications. Precambrian Res, , 42. $213-227$.

VEARNCOMBE, J.R.; BARLEY, M.E. EISENLOHR, B.; GRIGSON, M.W.; GROVES D.I; HOUSTON, S.M.; PARTINGTON, G.A. and SWARNERECKI, M.S. 1988 - Structural controls on gold mineralisation. In: Goode, A.D.T. et alii., eds. Gold 88, 22; 19 -23. 
VILJOEN, M.J. 1984 - In: Foster, R.P., ed. Gold' 82. Rotterdam, 753 pp.

WAKEFIELD, J. 1977 - Mylonitization in the Lethakane shear zone, Eastern Botswana. J. Struct. Geol,; 133; 262 - 275.

WOODALL, R. 1988 - Gold in 1988. In: Goode, A.D.T. et al, eds., Gold' 88. 22;01 -11 . 



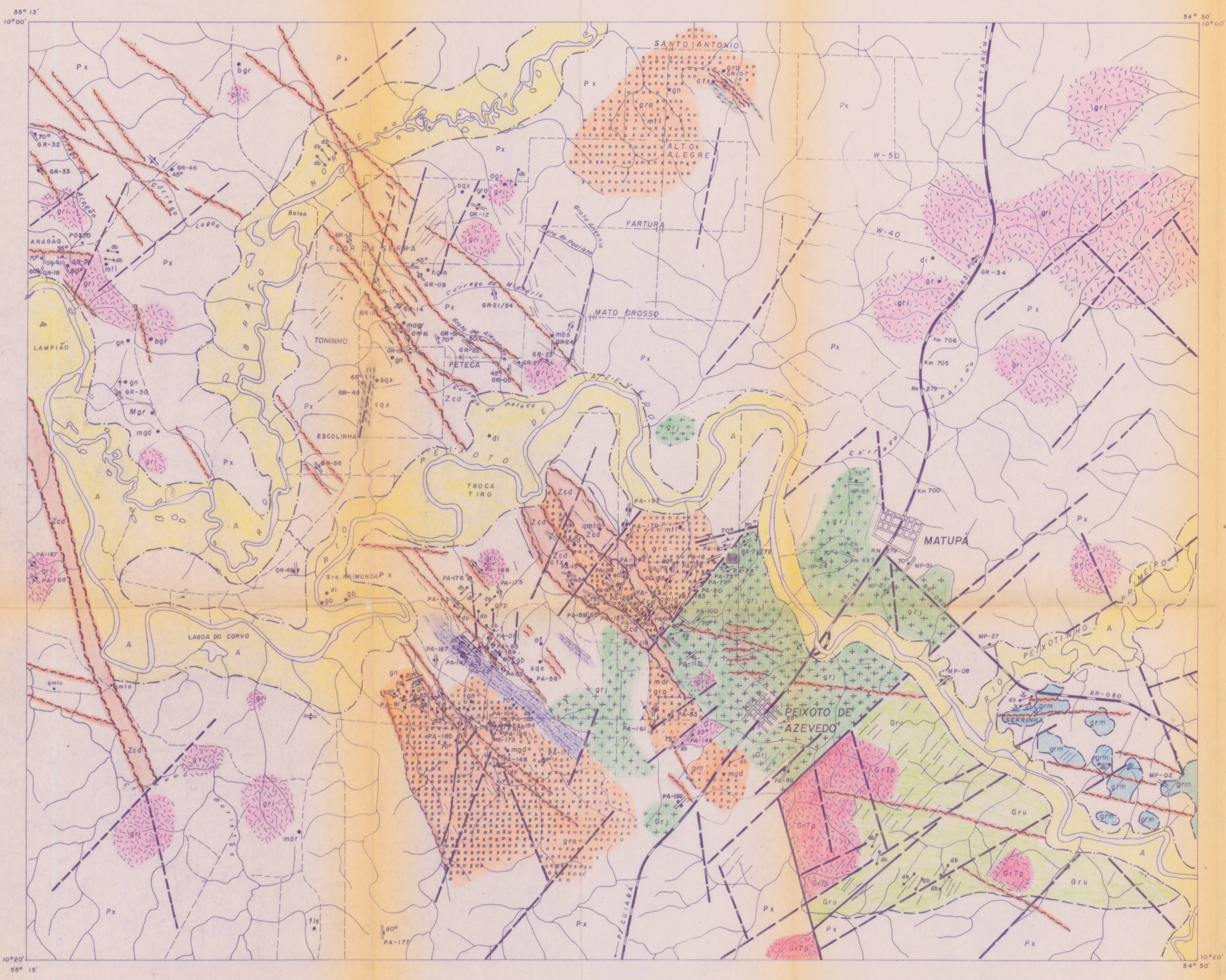

MAPA GEOLOGICO

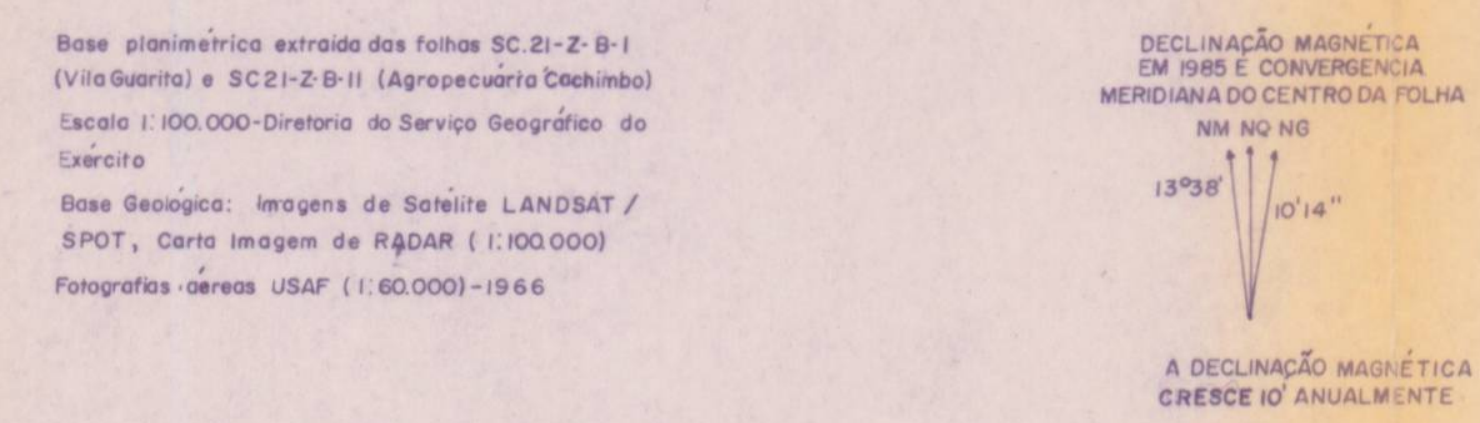

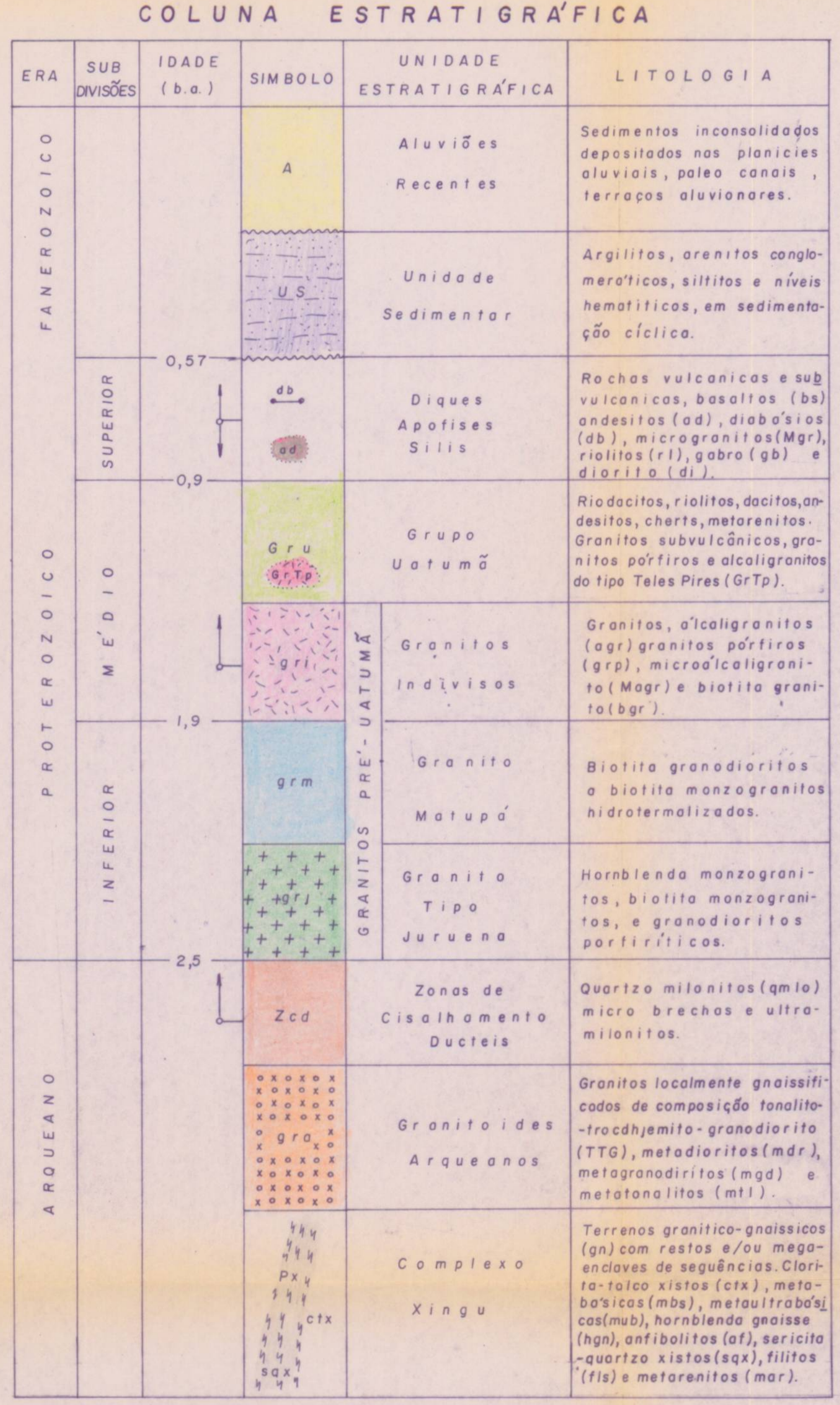

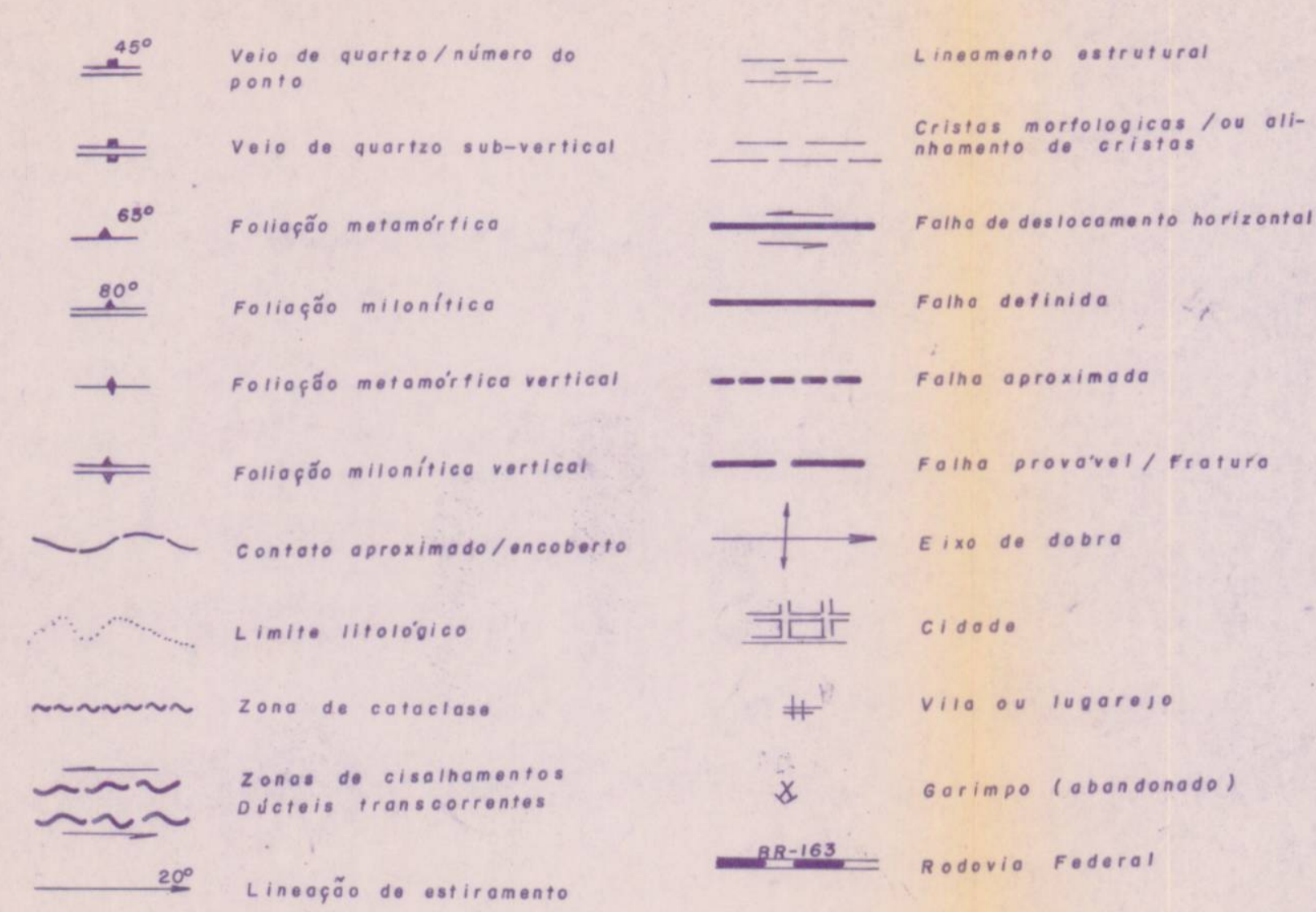

है है

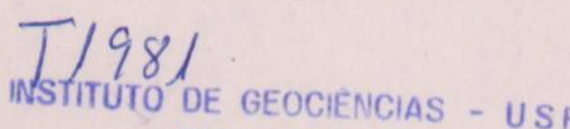

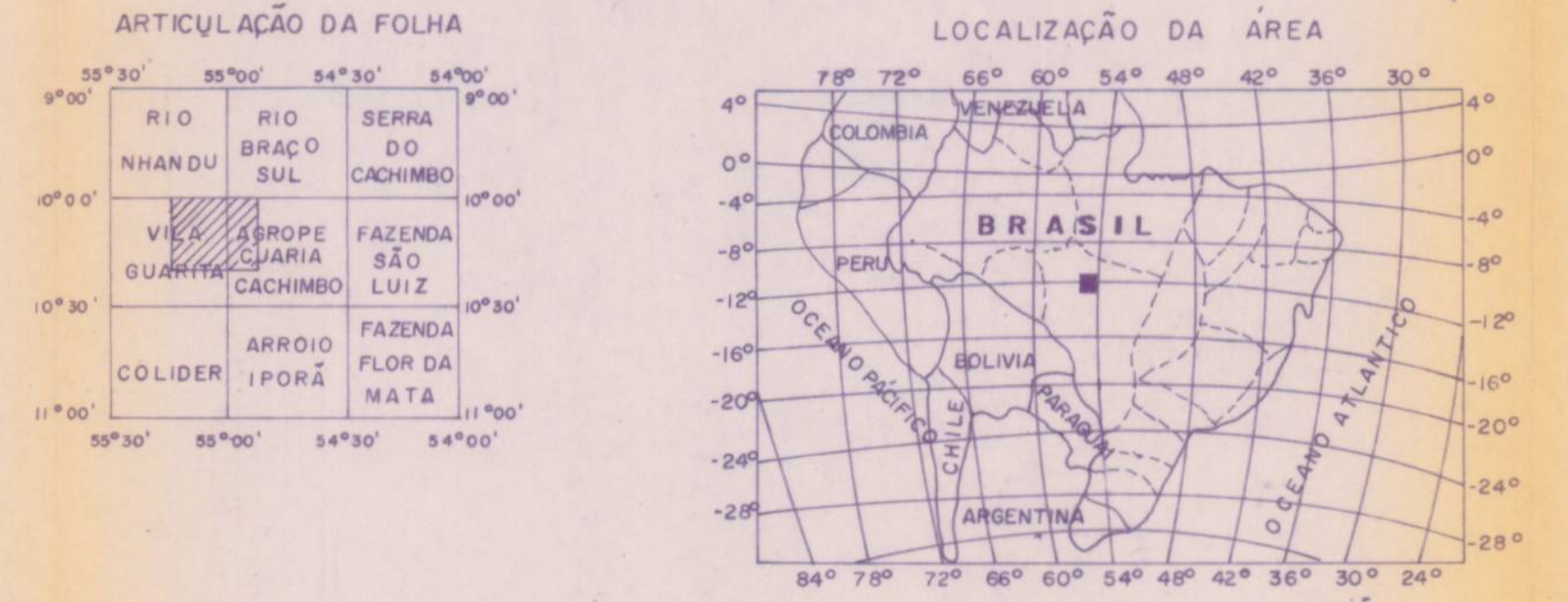




\section{ANEXO 02}

Mapa de Afloramentos e Áreas Degradadas 
